
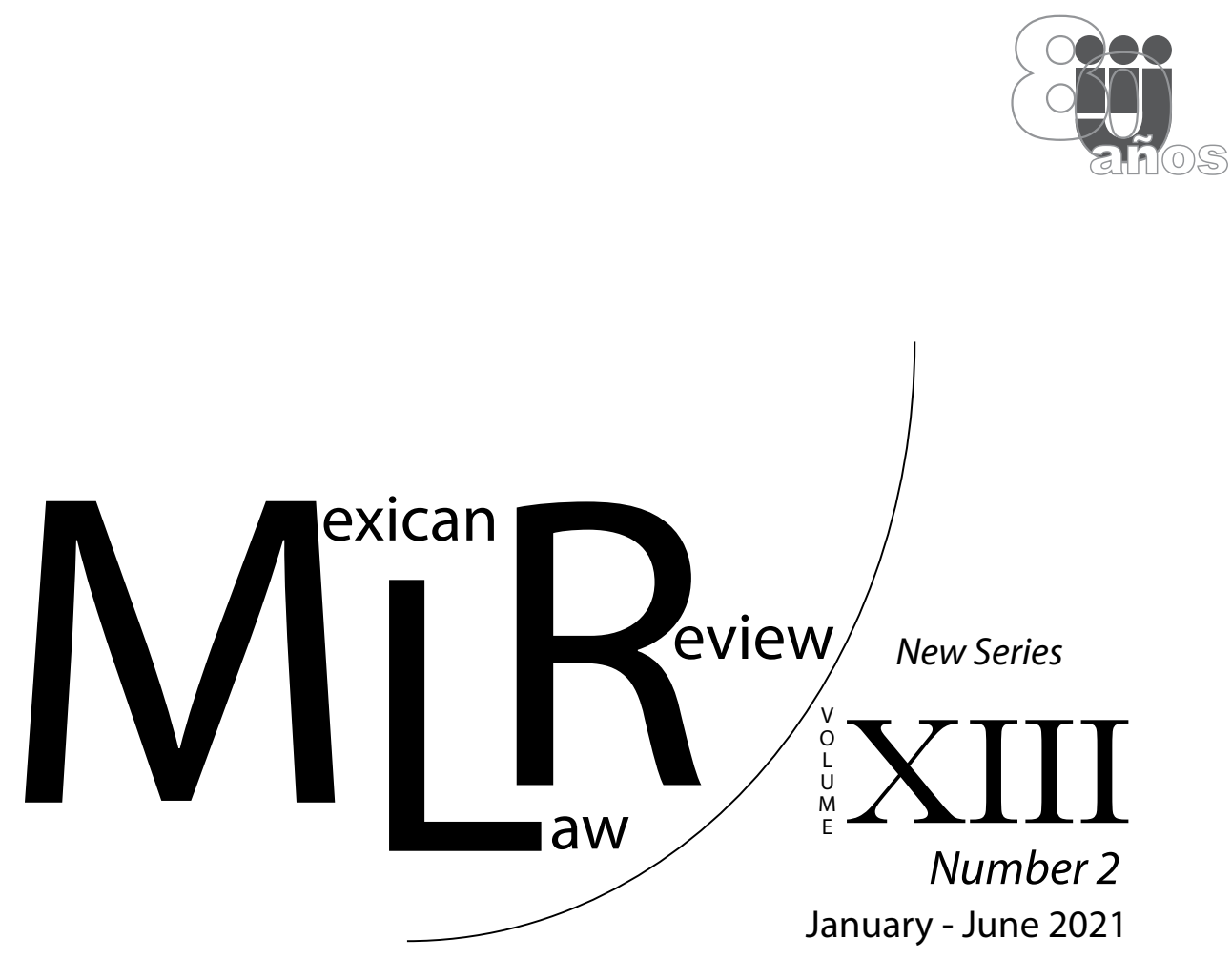

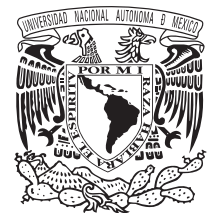

UNIVERSIDAD NACIONAL AUTÓNOMA DE MÉXICO

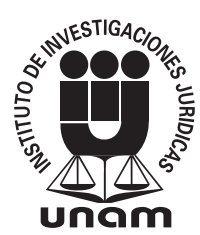

INSTITUTO DE INVESTIGACIONES JURÍDICAS 


\section{Mexican Law Review}

New Series

January - June $2021 \quad$ Volume XIII, Number 2

Editor-in-Chief

John M. Ackerman

Executive Editor

Wendy Rocha

Managing Editors

Rachel Ávila

Julio Valencia

\author{
Carmen Valderrama \\ Silvano Vitar
}

Copy Editors

Editorial Board

Manuel Becerra

Leticia Bonifaz

José Antonio Caballero

José Ramón Cossío

Héctor Fix-Fierro $†$

Imer B. Flores

María del Refugio González

Patricia Hansen

\author{
Carla Huerta \\ J. Jesús Orozco \\ Carlos Pérez \\ Gabriela Ríos \\ Alvaro Santos \\ José María Serna \\ Diego Valadés
}

Advisory Board

\author{
John Bailey \\ Georgetowen University \\ Mariano Florentino-Cuellar \\ Stanford University \\ H. Patrick Glenn $†$ \\ McGill University \\ Joachim Lege \\ Universität Greifswald
}

\author{
Jerry Mashaw \\ rale University \\ Michel Rosenfeld \\ Cardozo School of Law, Yeshiva University \\ Bill Weaver \\ Uniwersity of Texas, El Paso \\ Stephen Zamorat \\ University of Houston, Law Center
}

Interior design: Cristopher Raúl Martínez Santana 


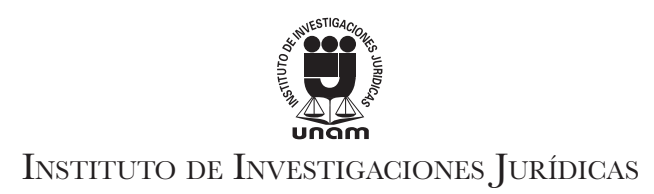

\author{
Pedro Salazar \\ Director \\ Issa Luna \\ Secretaria académica \\ Raúl Márquez \\ Secretario técnico \\ Wendy Rocha \\ Jefa del Departamento de Publicaciones
}

Mexican Law Review, nueva serie, vol. XIII, núm. 2, enero-junio de 2021, es una publicación semestral editada por la Universidad Nacional Autónoma de México, Ciudad Universitaria, Coyoacán, 04510 Ciudad de México, a través del Instituto de Investigaciones Jurídicas, Circuito Maestro Mario de la Gueva s/n, Giudad Universitaria, Coyoacán, 04510 Ciudad de México, teléfono 5622 7474, correo electrónico: ackerman@unam.mx. Editor responsable: John Mill Ackerman Rose. Certificado de Reserva de Derechos al Uso Exclusivo núm. 04-2010-102014301100-102. ISSN: 1870-0578.

Mexican Law Review por Universidad Nacional Autónoma de México, Instituto de Investigaciones Jurídicas, se distribuye bajo una Licencia Creative Commons Reconocimiento-No Comercial-Sin Derivados 4.0 Internacional (CG BY-NG-ND 4.0).

El contenido de los artículos es responsabilidad de los autores y no refleja necesariamente el punto de vista de los árbitros ni del editor.

Primera edición: 6 de enero de 2021

Mexican Law Review se encuentra registrada en los siguientes índices y bases de datos: Sistema de clasificación de Revistas Mexicanas de Giencia y TegnologíaConacyt (competencia internacional); SCOPUS; Latindex; Clase; Periodica; scielo (Scientific Electronic Library Online); Biblat (Indicadores Bibliométricos); Dialnet. 


\section{Mexican Law Review}

New Series

January - June $2021 \quad$ Volume XIII, Number 2

\section{ARTICLES}

1968: One YeAR IN THE Life OF THE

MeXican Federal Judiciary

Gaining Access to Justice: A

Subnational Study of Public

Defender Offices in Mexico

Municipalities as Part of the System to

Control Criminal Assets in Mexico

Permanent Economic Emergency in

Argentina and its Constitutional

IMPLICATIONS

Mexico's Legal Framework Regarding

Wastewater Management: A Gase

Study of Baja Galifornia Sur fuan Santiago Mlarri

87

Héctor Fix-Fierro $†$

3

Azul A. Aguiar-Aguilar

35

Pedro Rubén Torres

Estrada

63

Ana Teresa Valdivia

Alvarado

Alba E. Gámez

Luis Felipe Beltrán

Morales

Alfredo Ortega-Rubio

NOTE

Corruption, Rule of LaW and

Democracy: Concepts, Boundaries

AND OXYMORA

Stephen D. Morris

153 
ARTICLES 


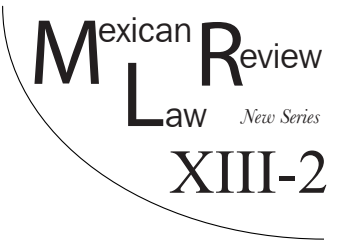

\title{
1968: ONE YEAR IN THE LIFE OF THE MEXICAN FEDERAL JUDICIARY*
}

\author{
Héctor FIX-FIERRO $(\boldsymbol{\dagger})^{* *}$
}

\begin{abstract}
In Mexico, it has acquired an almost sacred status. The student movement is commonly viewed as the beginning of the prolonged process of democratic transition that has unfolded in the last decades. Although there is very abundant literature about the events of that year, the role that the Mexican Federal Judiciary (MFF) played in them has practically not been examined. The article analyzes the situation and performance of the Supreme Court of Justice and the MFF during that single year. For this purpose, the essay examines the following aspects: the composition, organization and resources of the federal courts; judicial statistics; judicial precedents; judicial ideology and public perception on the justice system; and finally, the intervention of federal judges in the judicial proceedings instituted against the students and other leftist political dissidents. The article concludes that the MFF was subject to many constraints and limitations that, for good measure, hampered its role in the defense of constitutional order. Twenty years later the reforms leading to the transformation of the Supreme Court of Fustice into a constitutional court were started, favoring a more active intervention of judges and courts in the protection and defense of fundamental rights.
\end{abstract}

Keywords: Mexican Federal Fudiciary, student revolts, judicial backlog, judicial statistics, writ of amparo, democratic transition.

RESUMEN: 1968 es un año considerado mítico en varias partes del mundo. En México ha adquirido un estatus casi sagrado, pues se considera comúnmente al movimiento estudiantil de ese año como el inicio del prolongado proceso de transición democrática que se produjo en las últimas décadas. Aunque existe una bibliografia muy abundante sobre los eventos de ese año, prácticamente no ha sido examinado el papel del Poder Judicial de la Federación (PJF) en ellos.

* A Spanish version of this essay was presented and discussed at a seminar at the Institute of Social Research (UNAM) in September 2019 under the guidance of Ricardo Pozas Horcasitas. The author expresses his gratitude to the participants in the seminar for their insightful comments and suggestions.

** Full-time researcher at the Institute of Legal Research of the National Autonomous University of Mexico (UNAM) and Member of the National System of Researchers of CONACYT. 
Esta revista forma parte del acervo de la Biblioteca Jurídica Virtual del Instituto de Investigaciones Jurídicas de la UNAM

El artículo analiza la situación y el desempeño de la Suprema Corte de Justicia $y$ del PJF en su conjunto durante ese solo año. Para tal fin se estudian aspectos como la composición, organización y recursos de los tribunales federales; las estadísticas judiciales; la jurisprudencia; la ideología judicial y la percepción pública del sistema de justicia; finalmente, la intervención de los jueces federales en los juicios iniciados contra los estudiantes y otros disidentes politicos de izquierda. El examen concluye que el PJF estaba sometido entonces a un buen número de limitaciones que impidieron, en parte, que pudiera desempeñar un papel más relevante en la defensa del orden constitucional. Veinte años después se iniciaron las reformas encaminadas a la transformación de la Suprema Corte de Fusticia en un verdadero tribunal constitucional y que promovieron una participación más activa de jueces y tribunales en la protección y defensa de los derechos fundamentales.

Palabras clave: Poder Fudicial de la Federación, movimientos estudiantiles, rezago judicial, estadísticas judiciales, juicio de amparo, transición democrática.

\section{Table of Contents}

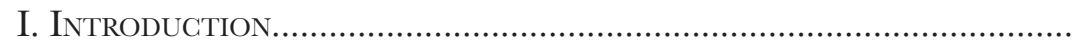

II. Composition, Organization, and Resources of the Federal JUDICIARY IN 1968

III. Judicial Statistics

IV. Judicial Precedents

V. Judicial Ideology and Social Perceptions on the Judiciary .... 21

VI. The Trials and Tribulations of 1968

VII. Gonclusion

\section{INTRODUCTION}

1968 is considered a mythical year in many parts of the world. Students took to the streets in protest and revolt in numerous countries: France, Germany, Italy, and the United States, among many others. According to Terry H. Anderson, 1968 was one of the most significant years of the $20^{\text {th }}$ century because in "many ways the year marked the end of the post-World War II period and the first phase of the 1960s, and the beginning of a new and very different era in the United States and Western Europe". ${ }^{1}$

In Mexico, the student movement of '68 has acquired an almost sacred status, as it is commonly viewed as the beginning of a prolonged process of democratic transition, in good measure due to the traumatic events of Oc-

1 Terry H. Anderson, 1968: The End and the Beginning in the United States and Western Europe, 16-17 South Gentral Rev. 1 (1999-2000). See also Michael Seidman, The Imaginary Revolution. Parisian Students and Workers in 1968, 1 ff. (Berghahn Books, 2004). 
tober 2 in the Plaza of the Three Cultures in Tlatelolco, Mexico City: the killing and disappearance, at the hands of government security forces, of a yet unknown number of mostly young persons who had peacefully assembled for a political rally that afternoon. ${ }^{2}$

There is a burgeoning number of studies and testimonies on the '68 in Mexico, ${ }^{3}$ but little attention, if any, has been paid to the role played by the Federal Judiciary (Poder Fudicial de la Federación), apart from justified critical comments on the sentences imposed by federal judges on the students and political dissidents who were arrested and prosecuted in connection with the unrest and protests of that year. However, had the Federal Judiciary, and the Supreme Court of Justice in particular, displayed a stronger defense and protection of the constitutional order and fundamental rights of Mexican citizens, the story of the Mexican '68 and subsequent political developments might have taken a different course. Therefore, an examination of the situation and performance of the Mexican Federal Judiciary in 1968 seems well in order.

Generally speaking, the Federal Judiciary is still one of the lesser-known institutions in the political and constitutional landscape of Mexico. This is certainly due to the subordinate position that courts and judges used to have vis-à-vis the other branches of power, particularly in relation to the all-powerful Federal Executive. This precarious situation notwithstanding, it should be recognized that Mexican courts and judges - and the Federal Judiciary in particular - did perform an important role during the post-revolutionary period. Although their decisions were not as independent as might have been expected, and even if they did not achieve the level of significance and authority to be desired, it is beyond doubt that Mexican judges made an important contribution to the legitimacy and stability of public institutions. In his classic study on Democracy in Mexico (1965), Pablo González Casanova had the following to say in his analysis of the role played by the Supreme Court of Justice until the early 1960s.

In view of all these data, one reaches the conclusion that the Supreme Court of Justice operates with a certain degree of independence vis-à-vis the Executive Power, and sometimes acts as a check on the actions of the President of the Republic or his collaborators. Its function is to allow, in particular, that certain actions and measures of the Executive be subject to review. Its main political function is to give hope to those groups and persons who are capable of using this remedy, for salvaging in particular their interests and rights...

2 Soledad Loaeza, México 1968: los orígenes de la transición, 30 Foro Internacional 66-92 (1989).

3 See, for example, the classical account of Elena Poniatowska, Massacre in Mexico (Missouri University Press, 1991). See also Elaine Carey, Plaza of Sacrifices: Gender, Power, and Terror in 1968 (University of New Mexico Press, 2005) and Jaime M. Pensado, Rebel Mexico: Student Unrest and Authoritarian Political Gulture During the Long Sixties (Stanford University Press, 2013). 
That the Supreme Court is a power — with the features just pointed out seems not to be in doubt, which does not prevent it from following, in their broad outlines, the policies of the Executive, and in fact serves to give it more stability. 4

This state of affairs has considerably changed in the past two decades, as a result of profound transformations in the Mexican political system, mainly for the purpose of curbing the overwhelming hegemony of the Presidency. One of those changes concerns the strengthening of the Federal Judiciary, and especially of the Supreme Court of Justice. Since the late 1980s, several constitutional amendments have given the Federal Judiciary a new organization and conferred it new powers. This, in turn, has led to a new bearing and a new visibility of courts and judges in Mexican society. Such transformations have coincided, on the whole, with an expansion of judicial power in other parts of the world. ${ }^{5}$

The new prominence of the judiciary in Mexico has awakened the interest in the study and explanation of this phenomenon, not only of legal scholars, but also of sociologists, economists, political scientists and other social scientists. As a result, there is an increasing array of studies that make ever more detailed and sophisticated contributions to the knowledge we have on the behavior and performance of judicial institutions in Mexico. But this is still not enough. On the one hand, there is a dearth of comprehensive historical and comparative studies aimed at explaining why and how the transition we have described originated and developed. ${ }^{6}$ Despite their evident interest and value, many studies take, as a departing point, the "reinvention" of the Federal Judiciary in the 1990s, which can only lead to a partial understanding of the relevant changes. ${ }^{7}$ On the other hand, in-depth case studies on particular aspects of the court system, such as the selection and appointment of judges, ${ }^{8}$ are also still lacking.

4 Pablo González Casanova, La democracia en México 36-37 (Era, 1997); English transl.: Democracy in Mexico (Oxford University Press, 1970). A similar view is held by Carl Schwarz, Fudges Under the Shadow: Fudicial Independence in the United States and Mexico, 3 Cal. W. InT'L L. J. 260 (1972-1973).

5 See the essays collected in The Global Expansion of Judicial Power (C. Neal Tate and Torbjörn Vallinder, eds., 1995).

6 But see Héctor Fix-Fierro, El poder del Poder Fudicial. El Poder Fudicial de la Federación en el siglo $X X$, in El poder del Poder Judicial y la modernización jurídica en el México contemporáNEO 233-316 (UNAM, 2020).

7 See José Antonio Caballero Juárez, De la marginalidad a los reflectores. El renacimiento de la administración de justicia en México, in Una historia contemporánea de MéXico: Las instituciones 163-193 (Ilán Bizberg and Lorenzo Meyer, eds., 2009).

8 See two recent studies on this topic: Julio Ríos Figueroa, El gobierno del Poder fudicial y la carrera judicial en México, 1917-2017, in Cien ensayos para el Centenario. Constitución Política de los Estados Unidos Mexicanos: Estudios políticos (Gerardo Esquivel, Francisco Ibarra 
This article has a modest purpose: to offer a "snapshot" of the Mexican Federal Judiciary in only one year, 1968. As argued above, the events of 1968 in Mexico have been the object of all manner of scrutiny, but no one has attempted to include the federal courts in the account. What was the position of the Federal Judiciary within the institutional landscape? What were the specific problems and challenges it was facing at the moment? How close or how detached from daily life were the cases then being resolved by the Federal Judiciary? What was the public perception on the justice system? What role did the federal courts play in relation to the tragic events of 1968? How effective was the protection they could accord to the fundamental rights of citizens?

This article aims to provide some elements for answering the preceding questions. To this effect, it will examine relevant information derived from several sources. The analysis has a self-imposed temporal limit, but occasional reference will be made to a slightly broader time frame. Thus, we will examine the composition, organization and resources available to the Federal Judiciary in 1968; the types and outcomes of the cases filed with the federal courts in the period of 1967-1969; the interpretations issued by the Supreme Court in 1968; the judicial philosophy of its members and their reactions to current events; the public perception on the honesty and effectiveness of the court system; and finally, the criminal proceedings instituted against the students and political dissidents arrested in connection with the events in Tlatelolco.

The above analysis will show that the Federal Judiciary operated in a social and temporal space that seemed to lie apart from the space occupied by the rest of the institutions. Whatever the judiciary does has a history, has antecedent causes and consequent effects, but it does so under such time conditions and such formal criteria that a relative uncoupling of adjudication in relation to current social or political events occurs. This is the result not only of the characteristics that define the judicial institution itself, but also of the strong endogamous organization of the judiciary in the civil-law tradition ("judicial career"). Another factor is the more or less conscious isolation cultivated by the judges themselves as an outflow of their view of judicial independence, as well as of the values pervading the legal order and the justice system, which were, and still are, conceived of as being above and beyond political and social struggles. Another particular cause contributed to the "splendid isolation" of the Federal Judiciary: its permanent, and largely unsuccessful, fight against rising workloads and backlog.

In view of the above, it is understandable to find only vague and indirect allusions to the movements and struggles of the day in judicial speeches and reports. More seriously, it is also evident that the Federal Judiciary was not in a position to adequately address the expectations and demands for justice that surfaced in Mexican society in 1968. They were very simple demands: freedom of (political) assembly and association, freedom of (political) speech,

Palafox and Pedro Salazar Ugarte, eds., 2017) and Héctor Fix-Fierro, La carrera judicial en el Poder fudicial de la Federación, in El PODER DEL Poder Judicial, supra note 6, 415-457. 
the right to personal liberty and integrity. All these rights and freedoms were already enshrined in the Mexican Constitution and the government made it a cause for national pride. However, the ideology of the Mexican Revolution paid no more than lip service to individual freedoms and rights because "social justice" was at the core of its political program. Thus, while the Mexican Constitution provided for a specific remedy against the violation of constitutional rights - the writ of "amparo"-, its effectiveness was clearly impaired not only by the constraints imposed on it by the legal order itself and by actual court operation, but also by the ideological and organizational environment of the existing political system.

Twenty years had to elapse before the regime could adopt a different approach to judicial reform, one that was not centered on the fight against back$\log$, but one that realized the need to enhance the organization and powers of the judiciary. On the basis of the judicial reform of 1987 and other subsequent reforms (1994, 1996, 1999, 2011), the Federal Judiciary and the Supreme Court began a slow and long-term process of the reinsertion of the judicial system into the social and professional environment, thus confirming again the idea that the connections between society and justice are complex and always subject to the influence of diverse social and political developments.

Perhaps the judicial reforms of the 1980s and 1990s are a late product of the dramatic events of 1968 , or at least it makes good sense to see them under that light. Those reforms were not necessarily started with a democratic agenda in mind, but the reformers could easily foresee, and accept, that the transformations they proposed had democratic consequences in the long run. Thus, the (hi)story of the Mexican Federal Judiciary in 1968 is still relevant to the challenges and perspectives we confront in our own days.

\section{Composition, Organization, and Resources of the Federal Judiciary in 1968}

According to the annual report of activities submitted by the president of the Supreme Court to his fellow justices at the end of 1968, the Federal Judiciary comprised the following bodies: ${ }^{9}$

The Supreme Court of Justice was composed of 25 justices (ministros): 21 justices, who sat in the plenary session (Pleno) of the Court, and four specialized chambers (salas), with jurisdiction in criminal, administrative, civil and labor

9 There were in 1968 several administrative courts outside the formal organization of the Federal Judiciary: the Fiscal Court of the Federation (Tribunal Fiscal de la Federación), the Federal Board of Conciliation and Arbitration (Funta Federal de Conciliación y Arbitraje), the Federal Tribunal of Conciliation and Arbitration (Tribunal Federal de Conciliación y Arbitraje), and the military courts. These courts are similar to the Article I courts that may be established by the Congress in the United States. However, they are expressly provided for in the text of the Mexican Constitution and the Federal Judiciary may review their final decisions. 
matters; 4 justices (so-called "supernumerary justices" or "ministros supernumerarios") who were part of the "Auxiliary Chamber" (Sala Auxiliar) established by the judicial reform of $1967 .{ }^{10}$

In 1968, the President of the Republic, Gustavo Díaz Ordaz (1964-1970), appointed three justices with ratification by the Senate: ${ }^{11}$ Ernesto Aguilar Álvarez, who at the moment was a supernumerary justice, was appointed as a titular justice, ${ }^{12}$ to occupy a vacant seat in the First (Criminal) Chamber, ${ }^{13}$ and two supernumerary justices, Salvador Mondragón Guerra, who could look back to a long judicial career (but only part of it spent in the Federal Judiciary), and Luis Felipe Canudas Orezza, with a professional background in the federal public administration, and particularly in federal and state justice systems. ${ }^{14}$ On January $1^{\text {st }}$ of that year, the voluntary retirement of Justice José Castro Estrada took effect, while the mandatory retirement ${ }^{15}$ of Supernumerary Justice Alberto González Blanco, and the voluntary retirement of the president of the Court, Agapito Pozo, were both approved to take effect on December $31 .{ }^{16}$

10 There was, therefore, one vacant seat in the Auxiliary Chamber.

11 See Roderic Ai Gamp, Mexican Political Biographies, 1935-2009 (4 $4^{\text {th }}$ ed., University of Texas Press, 2011). Professor Héctor Fix-Zamudio recounts that President Díaz Ordaz had reached an informal agreement with the Supreme Court, according to which the Court could nominate someone to fill a vacant position, and the President would freely choose on the following occasion. See Héctor Fix-Zamudio, Universitario de vida completa. MemoRIAS ACAdÉMICAS y RECUERdos PERSONALES 160 (UNAM, 2016). Presumably, the Court would prefer candidates with a prior judicial career, while the President would make his selection among candidates with an administrative or political background.

12 The supernumerary justices did not participate in plenary sessions of the Supreme Court, which was also the governing body of the Mexican Federal Judiciary. After 1968, the supernumerary justices formed an Auxiliary Chamber that decided the cases assigned to it by the Court. Frequently, as in the case of Justice Aguilar Álvarez, the President of the Republic would appoint a titular justice from among the supernumerary justices, thus making the latter position a kind of trial position before a promotion to a seat as a titular justice.

13 Justice Aguilar Álvarez was received in a plenary session of the Court on January 30, 1968. He had not followed a judicial career within the Federal Judiciary but had been a judge at the High Court of the Federal District (Tribunal Superior de Fusticia del Distrito Federal) before being appointed a circuit judge by the Supreme Court.

14 Both justices took their oaths of office before the Senate on October 10, 1968, and were received in public session by the Court on October 15 .

15 According to a law passed by the Federal Congress in 1951, all the judges of the Federal Judiciary had to retire on their $70^{\text {th }}$ birthday.

16 On the first meeting of the year, the plenary session of the Supreme Court elected its president, who could be reelected indefinitely. Justice Pozo had been elected its president in January 1965, one month after President Díaz Ordaz had taken office, and was reelected successively each year until his retirement at the end of 1968 (he had also been president for one year in 1958). He was succeeded by Justice Alfonso Guzmán Neyra, who had already been president between 1959 and 1964, i.e., during the entire term of President Adolfo López Mateos (1958-1964). He retired as president and justice at the end of 1973. Camp, supra note 11. 
According to the biographies of the sitting justices, they came from varied professional backgrounds; none had followed a full career at the Federal Judiciary, but 5 of them (22 percent) had held one or more lower judicial posts or had been District or Circuit judges before their appointment. ${ }^{17}$ Many had prior experience in state judiciaries (43 percent) and prosecutor's offices. This stands in contrast with the Supreme Court in the 1980s and 1990s, when more than half the justices had occupied most of the internal positions of the Federal Judiciary. ${ }^{18}$

At the close of 1968, there were 13 Circuit Collegiate Courts (CGCs or Tribunales Colegiados de Circuito), composed of three judges, with jurisdiction in "amparo" matters, ${ }^{19}$ and 9 Unitary Circuit Courts (UCGs or Tribunales Unitarios de Circuito), with only one judge hearing ordinary federal appeals (mostly in criminal cases). Thus, there were only a total of 48 circuit judges. Six of the existing CGGs and four of the UCGs had been established by the judicial reform of 1967 and had begun operating in October 1968. The number of District Courts (DCs or Fuzgados de Distrito) was also increased from 49 to 55, the first important growth in many years. (In 1930, there were a total of 46 DCs in a country with a total population of 16 million; in 1968, the size of the Federal Judiciary was slightly larger, while the population had almost tripled). Only 8 of the existing DGs had specialized jurisdiction and all of them had their seat in the Federal District. The rest of the DGs were distributed in 38 cities throughout the country, including 24 capital cities of the states. ${ }^{20}$

As can easily be seen, the total number of federal judges was quite small, i.e., 128 persons that could fit into a medium-sized conference room. There was only one woman among them, María Cristina Salmorán de Tamayo, who had been appointed justice to the Court in 1961 by President López Mateos while she was presiding the Federal Board of Conciliation and Arbitration (funta Federal de Conciliación y Arbitraje, a federal labor court). In the Federal Congress there were already women members (in the Chamber of Deputies since the federal election of 1955, and in the Senate since 1964), while in the Executive branch no woman had yet been appointed to a cabinet-level position. No other woman would be appointed to the Supreme Court until 1976. The Court began to appoint women judges in the 1970s, first as Circuit judges and later as District judges. ${ }^{21}$

17 Camp, supra nota 10; Semblanzas de los Ministros de la Suprema Corte de Justicia de LA NACión (1917-2013) (SCJN, 2013).

18 Fix-Fierro, supra note 8, 429-430.

19 "Amparo" (or "writ of amparo") is a procedural instrument for the protection of the constitutional rights of citizens in Mexico. For a still useful introduction to the Mexican "amparo" in English, see Héctor Fix-Zamudio, A Brief Introduction to the Mexican Writ of Amparo, 9 CaL. W. INT'L L. J. 306 (1979).

20 Since 1824, DCs in coastal states used to have their seat in the main port city and not the state capital. This is no longer so.

21 In 1984 there were only six women serving as District judges (6.6 percent) and five as Circuit judges (5.7 percent). Fix-Fierro, supra note 8, 431-432. 
The notable increase in the number of lower federal courts in 1968 required the appointment of a good number of Circuit and District judges. Their origins are interesting: a total of ten officials (clerks or secretarios) of the Court, 15 District judges and a judge of the High Court of the Federal District were promoted to the position of Circuit judge. The new District judges were selected among interim District judges (2 appointments), clerks to the District and Circuit Courts (17 appointments), federal public defenders (one appointment) and federal prosecutors (one appointment). ${ }^{22}$

With regard to these appointments, the president of the SCJ had the following to say:

It must be noted that in the appointment of these officials only the service record, honesty and competence of the favored persons were taken into account, and because the Supreme Court was absolutely independent in making its selection, it is solely accountable to public opinion for said appointments. ${ }^{23}$

And he went on:

...despite the lack of a specific law establishing a judicial career, the career ladder was practically used to reward the merits of the old servants of the Judiciary, thus expecting that their performance fully satisfies the imperatives sought after by the latest judicial reforms, whose transcendence and significance have been underlined on previous occasions. ${ }^{24}$

In fact, the internal hierarchy of the Federal Judiciary was not rigorously observed in the appointment process, i.e., that the Circuit judges had previously served as District judges, and that the District judges would be selected among the judicial clerks of the different court levels, as is the case nowadays. The Supreme Court of Justice had exerted considerable discretion in making its selections, taking mainly into account the record and performance of the candidates within the Judiciary, but without disregarding candidates from other areas of the justice system. In any case, the president's report underlines the independence and responsibility the Court assumed in its appointments policy, which were carried out well before the entry into force of the reforms, thus enabling the immediate installation and operation of the new courts. ${ }^{25}$

The appointment of judges was not the only personnel decision to be made by the Supreme Court, ${ }^{26}$ since the Court had also to ratify the appointment of Circuit and District judges after a four-year trial period; to decide on the

22 Informe Rendido a la Suprema Corte de Justicia de la Nación POR su Presidente el Señor Lic. Agapito Pozo al terminar el año de 1968, 24 (Antigua Imprenta de Murguía, 1968).

23 INFORME, supra note 22, 24.

24 Ibid., 25.

25 Ibid., 23.

26 Ibid., 24. 
promotion and assignment of judges and other Supreme Court officials, as well as to decide on leaves of absence, resignation and retirement. The following movements were observed in 1968: nine resignations (five for retirement pension, three for mandatory retirement and one resignation to an interim position), as well as 16 assignment changes of Circuit judges; one resignation, five ratifications, and 13 assignment changes of District judges.

In sum, the Federal Judiciary was barely larger than an extended family, and it is no accident indeed that it later came to be known as the "judicial family" (and not necessarily for the good reasons!), which meant that personnel policy and decisions were based on close personal relationships that allowed the appointing bodies and officials to evaluate the candidates in terms of their observed values, expectations, and commitment to the judicial institution. ${ }^{27}$ The number of personnel decisions and movements to be made by the plenary session of the Supreme Court year after year was relatively small and, as mentioned, enabled the way for a full appreciation of the professional trajectory of the officials concerned. At the most, the reforms of 1967-1968 forced the Court to temporarily alter the unhurried pace of the appointment, assignment and retirement of judicial officials.

The growth in the number of federal courts was made possible by a considerable increase in the budget of the Federal Judiciary. According to the Court president's report, a significant budget increase had been approved each consecutive year since President Díaz Ordaz had taken office in December 1964. The budgetary increase stood at 51 percent in nominal terms between 1965 (67 million old pesos) and 1968 (more than 97 million pesos), ${ }^{28}$ in a context of very low inflation. Thus, the Federal Judiciary was able not only to establish new courts, but also to solve other material and personnel needs. In 1968, the salaries of all the judicial personnel were increased, including those of Circuit and District judges, but excluding the salary of the justices. ${ }^{29}$

The increases had partly come about by way of budgetary extensions granted each year by the Secretary of Finances (Secretaría de Hacienda y Crédito Público, SHCP), reaching the sum of 4.3 million Mexican pesos in 1968. For 1969, the SHCP had fixed a budgetary ceiling of 101.8 million Mexican pesos, but the Court had proposed a budget of 110.3 million Mexican pesos (almost nine million pesos more). The budget finally passed by the Chamber of Deputies was 107.1 million Mexican pesos, a number halfway between the

27 José Ramón Cossío refers to a "tutorial model" of the judicial career that was in operation until the early 1980s. Its main feature was close personal contact between the candidates to a judicial position and the justices who had the power to recommend and approve their appointments. José RAMÓN COSSÍO, JuRISDICCIÓN FEDERAL Y CARRERA JUDICIAL (UNAM 1996).

28 Between 1954 and 1976, the exchange rate was 12.50 Mexican pesos to one U.S. dollar.

29 Informe, supra note 22, $29 \mathrm{ff}$. According to the testimony of Héctor Fix-Zamudio, in the late 1950s and early 1960s, the clerks at the Court (Secretarios de Estudio y Cuenta) supplemented their meager salary with other professional activities. The justices accepted such activities as long as they did not involve litigation and did not compromise the objectivity required of their judicial responsibilities. Fix-Zamudio, supra note 11, 80. 
Esta revista forma parte del acervo de la Biblioteca Jurídica Virtual del Instituto de Investigaciones Jurídicas de la UNAM

ceiling fixed by the SCHP and the amount sought by the Court, but representing no more than 0.16 percent of the entire Federal Budget for the fiscal year of 1969. ${ }^{30}$

Despite such increases, the president of the Supreme Court pointed out that, notwithstanding that the administration of justice still had to face serious deficiencies that required urgent attention, "the fact that with such rudimentary resources it has been possible to erect the monument of respect and hope with which the Mexican people rewards the Federal Judiciary [was well] worth praise, thus involving our responsibility...".31

\section{Judicial Statistics}

It is quite difficult to analyze judicial statistics belonging to just one year because without a data series comprising a reasonably long period, it is not possible to identify changes and trends. It is, however, a limitation that does not prevent us from making some noteworthy observations. To put the data of 1968 in a broader context, both the statistics corresponding to the years immediately before and after, i.e., 1967 and 1969, will also be analyzed.

The following table provides information on the docket of the Supreme Court during those three years:

\section{Table 1. Filings and Resolutions Before the Supreme Court (1967-1969)}

\begin{tabular}{|c|c|c|c|c|c|}
\hline Year & Existing & Filings & $\begin{array}{c}\text { Workload } \\
\text { (existing }+ \text { filings) }\end{array}$ & Resolutions & Pending \\
\hline 1967 & 19,994 & 11,644 & 31,638 & 11,305 & 20,333 \\
\hline 1968 & 20,333 & 11,521 & 31,854 & $24,644^{*}$ & 7,210 \\
\hline 1969 & 7,210 & 10,396 & 17,606 & $9,863^{* *}$ & 7,743 \\
\hline
\end{tabular}

* In 1968, the chambers and the plenary session of the Supreme Court decided only 10,404 cases (90 percent of those filed that year); according to the table, resolutions comprised 14,240 cases, which were transferred to CGCs $(12,442)$ and the Auxiliary Chamber $(1,798)$.

** In 1967, the chambers and the plenary session of the SCJN decided 9,863 cases (95 percent of those admitted that year); according to the table, resolutions comprised 2,085 cases, which were transferred to the Auxiliary Chamber and CCCs.

Source: Informes Rendidos a la Suprema Corte de Justicia de la NACión POR su Presidente EL SeÑor Lic. Agapito Pozo AL terminar los años de 1967, 1968, 1969 (SCJN, 1967, 1968 and 1969).

30 Presupuesto de Egresos de la Federación, que regirá durante el año de 1969, in Diario Oficial de la Federación (Official Gazette of the Federation), December 30, 1968. For purposes of comparison: the Presidency was assigned 34 million 034,000 pesos; the Congress, 83.8 million Mexican pesos; the Secretariat of National Defense, 1.67 billion Mexican pesos, and the Secretariat of Public Education, 7.3 billion Mexican pesos, from a total federal budget of 66.09 billion Mexican pesos.

31 INFORME, supra note 22, 37-38. 
As may be easily observed, between 1967 and 1969, the Supreme Court managed to settle almost all the cases admitted in those years (more than 90 percent). However, in 1967 it had already accumulated around 20,000 backlogged cases and it did not seem that such number could be reduced any time soon; on the contrary, the trend was headed towards still more growth. ${ }^{32}$ The table also reveals the immediate effect of the judicial reform of 1967 that took effect in October 1968 and allowed the Court (both plenary session and chambers) to transfer almost half of its workload, although the respective cases would still await decision by other federal courts. The data for 1969 suggest that backlog would grow again in the following years - as it so happenedbecause the number of pending cases at the end of the year was slightly (7 percent) higher than the number of existing cases at the beginning of the same year. In other words, pending cases before the Supreme Court were redistributed within the Federal Judiciary, but no real and lasting solution was achieved (even to this day) to the cyclic challenge of delay and backlog in so-called "judicial amparos"; that is, the appeal of final decisions of all the judges and courts of the country when violations of ordinary laws are involved.

Let us now look at the performance of CCGs according to Table 2:

Table 2. Filings and Resolutions before the CCCs (1967-1969)

\begin{tabular}{|c|c|c|c|c|c|c|c|}
\hline Year & $\begin{array}{c}\text { Number of } \\
\text { CCCs }\end{array}$ & Existing & Filings & Workload & $\begin{array}{c}\text { Average } \\
\text { workload }\end{array}$ & Resolutions & Pending \\
\hline 1967 & 7 & 2,061 & 8,714 & 10,775 & 1,539 & 8,907 & 1,868 \\
\hline $1968^{*}$ & 7 & 1,865 & 8,328 & 10,193 & 1,456 & 7,957 & 2,236 \\
\hline 1969 & 13 & 550 & 28,789 & 29,339 & 2,257 & 16,412 & 12,927 \\
\hline
\end{tabular}

* Although at the end of 1968 there were already 13 CCCs, we are only counting 7 because the data contained in the annual report only covers 10 months, until October.

Source: Informes rendidos a la Suprema Corte de Justicia de la NaCión por su presidente el señor Lic. Agapito Pozo al terminar los años de 1967, 1968, 1969 (SCJN, 1967, 1968 and 1969).

There are some minor inconsistencies in the data reported by the Court, but the table reveals that, up to 1968, filings before the CGCs totaled less than 10,000 cases a year, the largest part of which they managed to decide, amounting to an approximate average workload of 1,500 cases per court. The judicial reform of 1967-1968 transferred a large number of cases previously pertain-

32 The chamber with the highest backlog was the Second (Administrative) Chamber, with 7,598 "amparos" on appeal at the beginning of 1967. Fix-Zamudio, supra note 11, 73-74, refers to the crushing workloads affecting the chambers of the Court in the early 1960s. He claims that the so-called "Secretarios de Estudio y Cuenta" (literally translated as "Clerks of Study and Account") who prepared the draft resolutions for the Court were rather known as "Secretarios de Mucha Cuenta y Muy Poco Estudio" ("Clerks of Much Account and Very Little Study") because of the pressure under which they were required to work. 
Esta revista forma parte del acervo de la Biblioteca Jurídica Virtual del Instituto de Investigaciones Jurídicas de la UNAM

ing to the Supreme Court's jurisdiction to the courts. Despite the establishment of six new CGCs, the average workload climbed to close to 2,300 cases per court. This again lends support to the idea that the reform provided some relief to the Supreme Court, but the internal redistribution of cases within the Federal Judiciary did not solve any actual structural problem.

The following table reflects the cases filed and decided before the UCGs:

Table 3. Givil and Criminal Cases before the UCGs (1967-1969)

\begin{tabular}{|c|c|c|c|c|c|c|c|}
\hline Year & $\begin{array}{c}\text { Number of } \\
\text { UCCs }\end{array}$ & Existing & Filings & Workload & $\begin{array}{c}\text { Average } \\
\text { workload }\end{array}$ & Resolutions & Pending \\
\hline 1967 & 5 & 1,027 & 3,786 & 4,813 & 963 & 3,703 & 1,110 \\
\hline $1968^{*}$ & 5 & 1,110 & 3,672 & 4,782 & 956 & 3,826 & 956 \\
\hline 1969 & 9 & 1,022 & 4,248 & 5,259 & 584 & 3,950 & 1,309 \\
\hline
\end{tabular}

* Data cover only ten months, until October (the "judicial year" begins in the month of December of the previous calendar year).

Source: Informes rendidos a la Suprema Corte de Justicia de la Nación por su presidente el señor Lic. Agapito Pozo al terminar los años de 1967, 1968, 1969 (SCJN, 1967, 1968 and 1969).

These data reveal that workloads and cases pending before the UCGs at the end of the judicial year were relatively stable, but showed a significant reduction of the average workload in 1969, as a consequence of the establishment of four new UCCs in October 1968.

Finally, the following table presents statistical data related to the "amparo" cases filed and decided before the DCs between 1967 and 1969:33

Table 4. "Amparo" Cases before the DCs (1967-1969)

\begin{tabular}{|c|c|c|c|c|c|c|c|}
\hline Year & $\begin{array}{c}\text { Number of } \\
\text { DCs }\end{array}$ & Existing & Filings & Workload & $\begin{array}{c}\text { Average } \\
\text { workload }\end{array}$ & Resolutions & Pending \\
\hline 1967 & 49 & 10,318 & 50,449 & 60,767 & 1,240 & 50,888 & 9,879 \\
\hline 1968 & 49 & 9,879 & 51,942 & 61,821 & 1,261 & 51,752 & 10,069 \\
\hline 1969 & 55 & 8,907 & 58,615 & 67,522 & 1,227 & 58,254 & 9,268 \\
\hline
\end{tabular}

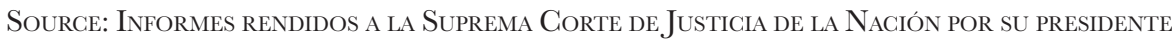
el señor Lic. Agapito Pozo al terminar los años de 1967, 1968, 1969 (SCJN, 1967, 1968 and 1969).

The preceding table is interesting because it seems to suggest that an increase in the "supply" of judicial services, by way of the establishment of

33 DCs are courts of first instance for ordinary federal cases (mostly civil and criminal), but they represent a rather minor sector of their total workload, so they are not included in the data of Table 4 . 
Esta revista forma parte del acervo de la Biblioteca Jurídica Virtual del Instituto de Investigaciones Jurídicas de la UNAM

new courts, almost immediately results in an increase in the "demand" of such service, so that any gain in processing capacity tends to decay quite quickly. Thus, we observe that between 1967 and 1969 filings grew by 16.2 percent and the total workload by 11.1 percent, but the resulting reduction in the average workload amounted to only 1 percent. Apparently, there was a large and still unmet demand for justice, as an outcome of an ever-more developed and dynamic society, but such demand had been stifled by the scant growth of the federal judicial apparatus in the previous decades.

The preceding data may be supplemented by information provided by the annual reports on outcome of the cases disposed of by the DCs, as presented in the following two tables:

\section{Table 5. Outcomes of Givil and Griminal “AMPAROS" BEFORE DCis ${ }^{34}$ (1967-1969)}

\begin{tabular}{|c|c|c|c|c|c|}
\hline Year & Resolutions & $\begin{array}{c}\text { Granted } \\
(\%)\end{array}$ & $\begin{array}{c}\text { Denied } \\
(\%)\end{array}$ & $\begin{array}{c}\text { Inadmissible } \\
(\%)\end{array}$ & $\begin{array}{c}\text { Dismissed } \\
(\%)\end{array}$ \\
\hline \multirow{2}{*}{1967} & \multirow{2}{*}{36,133} & $\begin{array}{c}4,648 \\
(12.9)\end{array}$ & $\begin{array}{c}4,303 \\
(11.9)\end{array}$ & $\begin{array}{c}2,142 \\
(5.9)\end{array}$ & $\begin{array}{c}24,512 \\
(67.8)\end{array}$ \\
\hline \multirow{2}{*}{1968} & \multirow{2}{*}{37,329} & $\begin{array}{c}4,700 \\
(12.6)\end{array}$ & $\begin{array}{c}4,284 \\
(11.5)\end{array}$ & $\begin{array}{c}2,360 \\
(6.3)\end{array}$ & $\begin{array}{c}25,474 \\
(68.2)\end{array}$ \\
\hline \multirow{2}{*}{1969} & \multirow{2}{*}{37,784} & 5,054 & 4,661 & 1,970 & 25,773 \\
& $(13.4)$ & $(12.3)$ & $(5.2)$ & $(68.2)$ \\
\hline
\end{tabular}

Source: Informes rendidos a LA SuPrema Corte de Justicia de la NAGión POR SU PResidente el señor Lic. Agapito Pozo al terminar los años de 1967, 1968, 1969 (SCJN, 1967, 1968 and 1969).

Table 6. Outcomes of Administrative and Labor "AMPAROS" BEFORE DCs (1967-1969)

\begin{tabular}{|c|c|c|c|c|c|}
\hline Year & Resolutions & $\begin{array}{c}\text { Granted } \\
(\%)\end{array}$ & $\begin{array}{c}\text { Denied } \\
(\%)\end{array}$ & $\begin{array}{c}\text { Inadmissible } \\
(\%)\end{array}$ & $\begin{array}{c}\text { Dismissed } \\
(\%)\end{array}$ \\
\hline \multirow{2}{*}{1967} & \multirow{2}{*}{14,755} & $\begin{array}{c}2,939 \\
(19.9)\end{array}$ & $\begin{array}{c}1,588 \\
(10.8)\end{array}$ & $\begin{array}{c}620 \\
(4.2)\end{array}$ & $\begin{array}{c}8,013 \\
(54.3)\end{array}$ \\
\hline \multirow{2}{*}{1968} & \multirow{2}{*}{14,423} & $\begin{array}{c}2,604 \\
(18.0)\end{array}$ & $\begin{array}{c}1,617 \\
(11.2)\end{array}$ & $\begin{array}{c}486 \\
(3.4)\end{array}$ & $\begin{array}{c}7,889 \\
(54.7)\end{array}$ \\
\hline \multirow{2}{*}{1969} & \multirow{2}{*}{20,470} & $\begin{array}{c}2,209 \\
(10.8)\end{array}$ & $\begin{array}{c}3,646 \\
(17.8)\end{array}$ & $\begin{array}{c}560 \\
(2.7)\end{array}$ & $\begin{array}{c}10,398 \\
(50.8)\end{array}$ \\
\hline
\end{tabular}

Source: Informes Rendidos a LA SuPRema Corte de Justicia de la NACiÓn POR SU PRESIDENTE el seÑor Lic. Agapito Pozo al terminar los años de 1967, 1968, 1969 (SCJN, 1967, 1968 and 1969).

34 For unexplained reasons, in the annual reports of the Supreme Court (until 1994), the statistical tables accumulate the outcomes of civil and criminal "amparos", as well as the outcomes of administrative and labor "amparos". This is surprising and peculiar, to say the least. 
The preceding tables show the probability of citizens being granted relief by the courts in "amparo" cases challenging the decisions of various public authorities. In civil and criminal matters, the percentage of "amparos" granted oscillates between 12 and 13 percent; the percentage of "amparos" denied is similar. ${ }^{35}$ Inadmissible "amparos", those that cannot proceed for lack of jurisdiction, are relatively few (between 5 and 6 percent). The highest percentage of decisions, however (about 70 percent, or more than two out of three), comprise dismissed cases, those in which the petition for relief was admissible, but in which the presence of a procedural obstacle prevented the judge from making a judgment on the merits (for example, the claimant could not produce evidence for the challenged decision). In administrative and labor "amparos" the situation is similar: the number of "amparos" granted did not exceed 20 percent, with a significant decrease in 1969 that went together with a notable growth of final decisions in administrative matters, from 12,584 in 1968 to 19,343 in 1969. The percentage of "amparos" denied oscillated between 10 and 11 percent, also with a significant increase in 1969; the percentage of inadmissible "amparos" remained low (2 to 4 percent), and cases were dismissed in a proportion reaching more than half of all decisions (between 50 and 55 percent).

How can we explain that the majority of resolutions by DGs involved dismissed cases? Several possible explanations have been advanced and probably all of them reflect some part of the truth: ${ }^{36}$ the incompetence of lawyers representing the claimants; judges need to control backlog, dismissing as many cases as possible in a context of increasing caseloads and almost zero growth in the number of courts (at least until 1968); the application of formalistic precedents, as defined both in statutes and higher court decisions, which prevent the judges from rendering a materially just decision; the filing of cases intended only to obtain temporal relief (a so-called "suspension"), as the case will be finally dismissed, etc. ${ }^{37}$

The predominance of dismissal decisions is somewhat puzzling if considered from the perspective of the "amparo" as a presumably simple and effective means of obtaining redress for the violation of the fundamental rights of citizens by all sorts of public authorities. The truth is that, beginning in the last

35 Regarding the outcomes in "amparo" filings, a decision may, at the same time, grant, deny and dismiss different claims within the same case. The data we are examining do not make this distinction, so we may surmise that they tend to reflect the main mode of resolution of a case.

36 A la PUERTA DE LA LEY, chap. 2 (Héctor Fix-Fierro, ed., 1994), Ana Laura Magaloni and Layda Negrete, Desafueros del poder. La política de decidir sin resolver, 2 TraYectorias. Revista DE Giencias Sociales de la Universidad Autónoma de Nuevo León (2000), Héctor Fix-Fierro, El AMPARO ADMINISTRATIVO Y LA MEJORA REGULATORIA 62 ff. (UNAM, 2005).

37 An example: a motor vehicle that has illegally entered the country. An "amparo" filed in this case has the sole purpose of temporarily suspending the possible confiscation of the vehicle by the transit authorities. Since the driver or owner of the vehicle will not be able to prove its legal stay in the country, the case will necessarily be dismissed. See Fix-Fierro, supra note 36. 
decades of the $19^{\text {th }}$ century, the "amparo" became an increasingly complex, technical, multifunctional and costly remedy of last resort for all types of violations of ordinary laws and not only of the Constitution. To these technical complexities one must add the existence of a legal environment shaped (and misshaped) by the crushing power of the Executive, so that citizens had to face even higher obstacles in their attempt to obtain a favorable decision against the frequent abuse of power. This is well reflected in the tables we have examined so far and this, in turn, may have contributed to making the mythical "amparo" somewhat less effective in relation to the dramatic political and social events of 1968, as we explain further on.

\section{Judicial Precedents}

Since the end of the $19^{\text {th }}$ century, decisions by the Supreme Court (and much later, also those of CCCs) were declared obligatory under certain conditions. Such conditions depended on the reiteration of the precedent a certain number of times (five), thus making such a precedent obligatory for all the lower courts, including state courts, but not administrative authorities, still bound by the principle of legality. Thus, a declaration of unconstitutionality had only the effect of invalidating the single act or decision challenged, i.e., no general or erga omnes effects were produced, but the existence of obligatory precedents ("jurisprudencia obligatoria", as opposed to "tesis aisladas", or isolated interpretations) made the granting of relief automatic if the facts of a subsequent case were substantially the same.

The interpretations ("tesis"), both obligatory and isolated, contained in the judicial precedents, as well as the full-text of some of the decisions, were published in the Semanario Fudicial de la Federación (Weekly Federal Court Report) according to selective and not-fully explicit rules. In January 1969, the Semanario started its $7^{\text {th }}$ epoch ("7a época") to reflect the changes introduced by the judicial reforms of 1967-1968. However, the Semanario was some years in arrear, thus preventing litigants and judges from learning of the most important and relevant interpretations in a timely fashion. For this reason, the annual report submitted by the president on the activities of the Federal Judiciary also compiled the most significant interpretations issued by both the plenary session and the chambers of the Court during the past year. In this section we present a brief quantitative and qualitative analysis of relevant interpretations corresponding to 1968 .

During 1968, the plenary session of the Court issued a total of 41 interpretations ("tesis") relating to the (un)constitutionality of laws in "amparos" on appeal ("amparos en revision"). Only five of these interpretations (about 12 percent) declared a law unconstitutional; 19 (46.3 percent) declared the respective law to be constitutional, and 17 more (41.5 percent) reflected other outcomes. ${ }^{38}$

38 INFORME, supra note 22, $139 \mathrm{ff}$. 
Among the issues addressed by the plenary session of the Supreme Court were fiscal topics (taxes, fees, budgetary laws), the problem of "frozen" leases, ${ }^{39}$ the rights of government employees, expropriation, the so-called "Article 123 schools", ${ }^{40}$ the freedoms of trade, work and association, the requirement of due process, and the scope of administrative arrest.

As an example of some of the issues of constitutionality discussed by the plenary session of the Court, we may cite the following:

- The decrees establishing a body for water supply management in the state of Morelos are unconstitutional because the users were not represented therein. ${ }^{41}$

- Administrative arrest ("arresto") imposed in a contempt-of-court ruling ("medida de apremio") is not unconstitutional (Article 73, section IV, of the Code of Civil Procedure of the State of Sinaloa). ${ }^{42}$

- The right to free and lawful association is not infringed by the requirement of leaving a chamber of industry and commerce before establishing a new one. ${ }^{43}$

- A requirement of minimum distance between commercial establishments of the same type as prescribed by statute (milk shops in the municipality of Torreón, state of Coahuila) is in violation of Articles 4 and 28 of the Constitution (freedom of trade and economic competition). ${ }^{44}$

- Compensation for expropriation may be paid in installments if it is not possible to pay the full amount immediately and the public need to be satisfied is urgent and justifies the occupation of private property (State of Veracruz). ${ }^{45}$

- The laws of the State of Nuevo León that establish taxes on non-enclosed urban property are unconstitutional, for violating the principle of

39 In 1942, in connection with the wartime emergency measures adopted by the Mexican government, a decree was issued "freezing" the amount the owners of real estate for lease could charge their tenants. The decree was not abolished once the war was finished but was indefinitely extended. In Mexico City this regime lasted until 2001. See María José García Gómez, El impacto de la Ley de Renta Congelada en la Ciudad de México (1942-2001), in EL MUNDO DEL DERECHO II: Instituciones, JUSTICIA Y CULTURA JuRÍDiCa 487-511 (Andrés Lira and Elisa Speckman Guerra, eds., 2017).

40 The name refers to Article 123 of the Mexican Constitution. According to the original section XII of this Article, the owners of agricultural and industrial enterprises had the obligation to provide elementary education to the children of their workers. See Engracia Loyo, Escuelas rurales "Artículo 123", 40 Historia MEXicana 299-226 (1990).

41 Amparo en Revisión (AR) 4390/57, decided on June 4, 1968; with a majority of 14 votes.

42 AR 7984/57, decided on March 19, 1968.

43 AR 74/61, decided on February 13, 1968; unanimity of 19 votes.

44 AR 4080/63, decided on September 24, 1968; unanimity of 17 votes.

45 AR 964/65, decided on October 1, 1968; unanimity of 16 votes. 
tax legality and for imposing an exorbitant and ruinous tax rate infringing upon the principles of tax proportionality and equity. ${ }^{46}$

Considering the nature of the "amparo" and the traditional modes of operation in the courts, the preceding examples show that it was the business of the Supreme Court to decide on concrete constitutional questions by making very specific rulings that, although binding for the lower courts in similar subsequent cases, had a limited scope insofar as they did not make broad statements regarding the interpretation of fundamental rights. Thus, such interpretations belong to a period of judicial doctrine characterized as "statist" and "minimalist", i.e., by the display of an increasing degree of deference towards public authorities due to the deliberate reduction of the scope of interpretations on individual rights and the consequent enlargement of the possibility of declaring any action or decision of those authorities as constitutional. ${ }^{47}$ Many of the decisions were unanimous (but with less than 21 votes), thus suggesting that the issues examined had not been particularly controversial (and perhaps regarded as not very important by the absentee justices).

Moreover, due to the natural delay of judicial proceedings, in 1968 the Supreme Court was deciding cases that had been filed in the lower courts in the late 1950s and early 1960s. In other words, the Court was not deciding the important issues of the day (or at least, of the previous year), but cases with individual relevance and perhaps lesser social significance. Such cases, nevertheless, required a final decision by the highest Court of the country. In addition to this, the amendment of 1958, which transferred the declaration of unconstitutionality of laws from the individual chambers to the plenary session of the Court, provoked a still slower pace in the operation of the latter: the plenary session met only once a week, not only to decide cases, but also to address other governance and administrative responsibilities on behalf of the whole Federal Judiciary. ${ }^{48}$

With respect to the chambers, once they lost the power to declare the unconstitutionality of laws, their activity concentrated still further on the interpretation and application of ordinary statutes, also in a concrete and casuistic fashion. From a present-day perspective, there are not many interpretations ("tesis") issued in 1968 that would arouse any particular interest. The production data for the chambers in that year are as follows:

The First (Criminal) Chamber published a total of 60 "tesis", almost all of them deriving from "amparos" against judicial decisions, and mostly related to

46 AR 3518/66, decided on July 30, 1968, unanimity of 16 votes.

47 José Ramón Cossío Díaz, La teoría constitucional de la Suprema Corte de Justicia $114 \mathrm{ff}$. (Fontamara, 2002).

48 Fix-Zamudio, supra note 11,81. Schwarz, supra note 4, cites a study by then-Justice Tena Ramírez, which examined the impact of the 1958 amendment on the increasing delay in the review of unconstitutional laws by the plenary session of the Court. 
technical and specific aspects of the criminal legislation. None appears as an obligatory precedent.

The Second (Administrative) Chamber had a very large area of jurisdiction to cover. Besides interpretations in administrative matters stricto sensu (15 "tesis"), there are another 31 "tesis" in agrarian matters; 56, in tax matters; and 6 , in social security matters. Another 61 interpretations were related to further administrative issues, yielding a total of 163 "tesis".

The Third (Civil) Chamber issued a total of 37 interpretations in "amparos" against judicial decisions, also relating to technical and specific aspects of the civil and commercial legislation of the whole country. Most of them are isolated, non-obligatory "tesis".

The Fourth (Labor) Chamber issued 12 obligatory "tesis" and 22 isolated interpretations, regarding both procedural and substantive aspects of labor and employment legislation, which has belonged to federal jurisdiction since 1931. These interpretations could have a fairly significant impact on the activities of both workers and employers, as they were to be applied by the labor justice bodies (Boards of Conciliation and Arbitration).

As can be easily observed from this overview, although the cases decided by the Supreme Court of Justice concerned the most diverse issues and matters, its activity was concentrated in the decision - mainly through the chambers, as the plenary session had a very low processing capacity - of a large number of "amparos" against judicial decisions; that is, it purported to put an end to the ordinary controversies between citizens and between citizens and public authorities. This was a further manifestation of the dominant centralism, which was of a legal as well as a political nature. In view of the prevailing lack of confidence in the state courts (which persists to this day), a large proportion of litigants sought and obtained an opportunity to be heard by federal courts and, especially, by the highest court in the land. As a consequence, the role of the SCJ as the supreme and final interpreter of the Constitution was obscured and almost buried under the avalanche of cases that concerned only the faithful interpretation and technical application of ordinary laws and codes. This state of affairs was to be deeply altered by the judicial reforms of 1987 and 1994, to which we will refer later.

\section{Judicial Ideology and Social Perceptions on the Judiciary}

While in many common-law countries - like the United States - the personal and professional ideology of candidates to a judicial position is crucial for deciding on their selection and appointment, as it possibly anticipates the policies they may pursue, in civil-law countries like Mexico, the political and ideological profile of judges is much less significant (except perhaps for judges deciding on constitutional issues) as their role and function is traditionally viewed to consist in the "strict application of the laws". Their personal and professional 
preferences are concealed behind the law, as a sort of protective shield that legitimizes and justifies their decisions in impersonal terms. For this reason, it is difficult - to this day - to ascertain a definite ideological and political profile of Mexican judges, including their most conspicuous representatives: Supreme Court justices.

In view of the above, we can hardly doubt that, in 1968, members of the Mexican Federal Judiciary preferred to "speak through their decisions", using formal and technical formulas that would preclude us from directly approaching their political, social and legal thought. However, they frequently pronounced speeches on formal occasions (on the appointment or retirement of a justice, the opening of new courts, etc.), thus providing us with an interesting source of knowledge and insight regarding their legal and political ideas. The president of the Court also took advantage at the submission of the annual report of the Court's activities to give a message that might be significant beyond the walls of the High Court. In this section we briefly examine a few speeches of the justices during the year of 1968.

In his last annual report as president of the Court, Justice Agapito Pozo had the following to say.

...the fact that with such rudimentary resources it has been possible to erect the monument of respect and hope with which the Mexican people reward the Federal Judiciary is worthy of praise, thus involving our responsibility; because whatever the defects and deficiencies of regimes of legality may be, it will always be true that they surpass in benefits those that have intended to replace them, especially when innovators are characterized by their destructive aims of everything that civilization has accumulated in the course of centuries and, above all, by the annihilation of the human person in her liberty and the respect she deserves.

Each generation desires to preserve, without blemish, the banner under whose shadow it has fought its battles and struggled for the endurance of the principles inspiring its ideals. It befalls us to erect the banner of legality in the chaos of the violence that threatens us, and should anyone intend to tarnish it with arbitrary actions, may the daily proclamation we make still be heard within the horizons of the Fatherland: "The Justice of the Union protects and safeguards...". ${ }^{49}$

These paragraphs seem to allude to the revolutionary impulses that the $\mathrm{Cu}$ ban Revolution had strongly reawakened in Latin America during the 1960s, and perhaps also - in a rather oblique way - to the student movements and social protests of that year in Mexico. The speech discredits such movements and protests to the extent that they are radical, violent and destructive of what "civilization has accumulated" until that moment. Nevertheless, it does not attempt to make a direct defense of the political regime existing in Mexico at the time, but of legality as a system that allows for ordered and gradual change,

49 INFORME, supra note 22, 37-38, 39. 
and of its ultimate guardian, the Federal Judiciary, which has the power to "protect and safeguard" ("amparar y proteger") citizens against any arbitrary action of public authorities. In this sense, it may not be argued that the speech reflects a merely conservative or reactionary position. It should be noted that the president of the Supreme Court did not go on to praise President Díaz Ordaz for "saving" the institutions and the political order of the Republic that year, as others had openly done, ${ }^{50}$ but merely thanked him for the support that had made the judicial reform possible.

In other speeches given that same year we find more clues on the justices' thoughts regarding the work that the Federal Judiciary carried out daily, as well as the qualities and abilities required by the task of adjudication. We start by citing, rather extensively, some relevant paragraphs from the speeches given by the three new justices appointed to the Court in 1968. On January 30, 1968, after the words of welcome pronounced by the president of the Court, Justice Ernesto Aguilar Álvarez pointed out the following:

I acknowledge that the appointment favoring me does not belong to me personally, but as a member of the Judiciary, because its motive is surely to encourage District and Circuit judges who have diligently devoted their efforts to the judicial service, and it represents an impulse made by the Executive with the intention to activate, no doubt, the judicial career as an adequate means to achieve, together with judicial stability, a justice [that is] ever more independent and effective...

I realize that from now on I assume, before you and the Republic, a commitment to fulfill the high obligation of sharing, in the plenary session, the responsibility of deciding on the lofty national problems affecting the country's life and whose resonance reaches the entrails of the Fatherland, because interior peace, social balance, and public tranquility depend on the legal order that imposes itself precisely through the right decisions of this High Court...

I also know well that I should, at your side, look after the preservation of the Supreme Court's sovereignty, as well as its power of constitutional review of legislation and actions by public authorities, and its role as the supreme interpreter of the Constitution, gathering experiences from reality so that justice becomes the contents and goal of the law. In order to accomplish this most elevated mission, it is necessary to have abnegation as sacrifice, self-denial as largesse of spirit, discipline at work as order and unity in dynamic action, and the spirit of collective honor that is the splendor of virtue at the service of the group, and those forces, which undoubtedly prevail in this House, that have

50 So, for example, in response to the State of the Union address of President Díaz Ordaz on September 1 $1^{\text {st }}$ 1968, federal deputy José de las Fuentes Rodríguez closed his speech with the following words: "And therefore our people, Mr. President, close ranks around you; they ratify their faith in the statesman's qualities that distinguish you and they reaffirm their passionate confidence, because they know that, under your leadership, they may safely march along the broad paths you have marked towards unblemished patriotism, dynamic peace, material progress, and moral improvement". Informes PREsidenciales - Gustavo Díaz Ordaz 309 ff. (Cámara de Diputados, ed., 2006). 
made it possible for the Federal Judiciary to guarantee the atmosphere of peace in liberty and the enjoyment of freedom in justice that nourish the principles of the common good of society, and which inspire our institutions and are desired by the civilized men of the world, today more than ever, where unrest, fear and anxiety are threatening and in which it is necessary to strengthen the courts as a permanent school of civic virtue, so that human coexistence becomes more fruitful, thanks to the victory of the Law over force...

The members of this Branch of Federal Power are the most responsible heirs of a tradition emanating from the incessant struggle that our people have fought to preserve its independence and liberty, predicated on democracy and social justice; public institutions have granted us the legal instruments necessary to preserve the harmony enjoyed by Mexicans, thanks to the rule of law that promotes public peace; we are obliged, then, to strengthen the inalterable value of the law and to transmit, enriched, the national ideals that guarantee to the new generations a better order, sealed with the enduring sign of justice. For my part, I declare with the full force of my deep conviction that I will not spare any effort or sacrifice to fulfill this non-transferable duty. ${ }^{51}$

On his reception as supernumerary justice of the Supreme Court (on October 15, 1968, just 13 days after the events of Tlatelolco!), former Circuit judge Salvador Mondragón Guerra spoke the following words:

I am aware that my full dedication to the administration of justice has been one of the most powerful motives that the Chief Executive has taken into account for deciding my appointment, thus confirming the purpose of stimulating the establishment of the judicial career, and it has also been the spirit prevailing in this Supreme Court...

Contact with justice reveals that in it the grounds of existence are found, although there are not a few who, because of their skepticism, have lost faith in it. Whoever makes the law prevail, as a way for the realization of what is just, have convinced themselves that the function of law tends to be something more than "dead letter", transforming itself into an effective form of social life. When Mexicans, be they knowledgeable or not in the law, turn their eyes towards the Supreme Court, they see it cloaked in clarity, because justice and the law are here tied together for the sake of coexistence, bringing, as far as possible, the reality of justice achieved closer to the idea of justice aspired.

No one doubts that our era lives under the sign of restlessness and rejection; the law has not escaped incredulity, and justice is deemed fragile and insufficient; whoever proclaims the law as a safeguard of order and liberty, oppose those who naturally lead towards anarchy; but the law, taken as a whole, is no more than an abstract statement; the designation of that which men have no other choice but to do because of the sheer fact of living in society. Those who think that the judge, in applying the law, lives an anguishing and dramatic situation are right...

The lack of understanding and the bitterness that frequently overwhelm us are compensated, on the other hand, by the higher possibilities provided to the rule of law, as the best instrument for the common good...

51 INFORME, supra note 22, 90-92. 
The Constitution is not a dry and formal legal body; it is not enough to state its texts, it is indispensable to incorporate them into daily life and to turn them into everyday reality. The Federal Judiciary is in charge of this great responsibility... ${ }^{52}$

In his speech of reception as an auxiliary justice of the Court, on the same session of October 15, 1968, Luis F. Canudas Orezza expressed the following ideas:

Let me first leave proof of my warm appreciation of Licenciado don Gustavo Díaz Ordaz, worthy President of Mexico, for the deference of which he has made me an object of, by conferring me this assignment. I shall never forget the words which my dear friend Luis Echeverría, Secretary of Interior, said to me last Wednesday morning: "The President has appointed you justice of the Supreme Court...".

The reform, recently introduced into the Constitution, of the "amparo" and the organization of the Federal Judiciary, with the establishment of an Auxiliary Chamber of this High Court, modifies the powers of its supreme body. Let us hope, my fellow justices, and let us make of it a commitment of honor, that this is the last time the Supreme Court declines its jurisdiction in favor of lower federal courts.

From the entry into force of the Constitution of 1917 to this date, the attempted solution to the backlog has been the diminishment of our jurisdiction or the establishment of new courts, without considering that this results in its disintegration and in the extinction of its qualities as a branch of power.

...Do not let the Constitution fall into inertia, my fellow justices, because an inert Constitution may imperil the institutions, the limitations imposed by it on power and even the validity of the human rights of most notable ancestry.

Let us concentrate our efforts so that the evolution of Public Law in Mexico becomes the work of the Supreme Court of Justice. We should not allow that the only advancement of the principles informing the Constitution are due to reforms introduced and achieved by the other branches of power. Let us have faith, above anything else, that the constitutional dynamics are in the hands of the Federal Judiciary... A Constitution modified through judicial precedent is always the work of constitutional science and not of transitory circumstances...

Historically speaking, within the State only constitutional powers have been limited powers. Nevertheless, our efforts should be directed towards the constitutional control of those social powers that affect and destroy man's freedom in the present hour...

The Constitution arose to crush the desire for domination that characterizes power, which continuously forgets that the violation of human rights is a menace to world peace...

It was not by whim or fancy that the Independence, the Reform and the Mexican Revolution of 1910 created and perfected even more the rule of law in Mexico. A permanent calling to the enjoyment of liberties is in the being of Mexicans; it is a mystical pact for the establishment of freedom of thought; it is 
a supreme conviction for the enjoyment of the right to work, to a fair salary and to the equitable distribution of land.

A Mexican feels the perils of a world turned insane by power very closely, and therefore, he demands equal economic opportunity for him and his family, and to have participation in all the tasks entrusted to Government. We are extremely jealous of the values of the spirit, because we are persuaded that the true investment of capital in the modern State is not represented by machines but by schools, not by economic power but by the right to culture...

The problem of our time, which I know well cannot be alien to the reflections of this honorable Supreme Court of Justice of the Nation, concerns the relations between power and liberty...

Without safety there shall never be liberty; but lacking liberty there shall not be safety either...

Liberty is lived and is not perceived; but since liberty is lived within the State community, it is the obligation of any judicial body in the world to provide liberty with safety.

Societies ruled by money and by the exploitation of man by man have never taken care of the rule of liberty and justice...

Power exists to save the dignity of man through dignified means, even under the shadows of a world that does not desire to be deserving of it.

Liberty may be doubted; there may be blunders transitorily overshadowing it; but always, in the face of power as force, the idea and the spirit shall survive as its insurmountable essences, and Prometheus shall again find the sacred paths of liberty. ${ }^{53}$

From the paragraphs we have cited, a clear difference in both contents and style may be perceived between the speeches of the two justices with a judicial background (Aguilar Álvarez and Mondragón Guerra) and the justice coming from the public administration and in particular from the Attorney General's Office (Canudas Orezza). The former converged on many of the issues they examined. One of them is the judicial career and the impulse given to it by the Court itself and now also by the Executive, which is a reason for gratitude. In this sense, they underlined the conditions of self-sacrifice and abnegation under which adjudication is carried out: it is a silent and arduous task, subject to many personal and material restrictions, but which, nevertheless, turns out to be indispensable for the survival of the Republic. Therefore, in a second moment and using the rhetoric typical of the legal profession, they outlined a judicial philosophy in which the Federal Judiciary, and in particular the Supreme Court, had an elevated social role in the maintenance of social peace through the law and legality. These values were fleshed out in the Constitution, serving as a repository of national ideals whose defense and protection had been entrusted, precisely, to the Judiciary. In particular, they both emphasized that through the power of judicial review and the ultimate interpretation of the constitutional text, the Court could exert considerable

53 Ibid., 103-110. 
influence on the most sensitive issues of public life. ${ }^{54}$ The fulfillment of this function - they went on - was grounded on the recognition and trust that the Mexican people had granted the judicial institution. Nevertheless, in their view, law, legality and justice, as well as the climate of peace and tranquility prevailing at the time, faced clear threats, going from the skeptical stance of some to various forms of protest, disorder and anarchy, which were, for this very reason, rejected. Therefore, they insisted again on the central role of judges in sustaining the rule of law.

We do not find in these speeches any direct or specific mention neither of actual events in the country that year, nor of the protest movements of past years (for example, the movement of medical interns in public hospitals in 1964-1965), ${ }^{55}$ but it is unlikely that the justices would not have had them in mind as they drafted their speeches. What they had seen and witnessed in those years would have surely reinforced their conviction that the Constitution, legality and justice, as ultimately safeguarded by the Federal Judiciary, were the only path for fighting disorder and anarchy, as well as for mending the abuses of power.

Justice Canudas Orezza's speech reveals various levels of depth that merit specific comment. Firstly, it is clear that the justice had a very close relationship with the ruling group of that moment, as he (rightly) assumes that only the President is to be thanked for his appointment, because the Senate could not, and did not play, any significant role in his confirmation. In second place, and somewhat surprisingly, Justice Canudas Orezza is critical of the judicial reform recently passed at the initiative of the same President (but prepared by the Court itself), to the extent that it required a transfer of jurisdiction from the Court to other lower federal courts (CCGs). In his eyes, such a transfer implied a deterioration of the Court's authority that had to be prevented in the future because the Court had a central role to play in constitutional interpretation and in the development of public law. Once again, this critical stance turned out to be inconsistent with the reality of the Court at the moment because it was not only the political regime, nor the specific distribution of powers within the Court and the Judiciary itself, that hampered the Court's role as the ultimate interpreter of the Constitution, but a crushing workload made up of ordinary, non-constitutional cases. ${ }^{56}$ In fact, subsequent reforms - especially in 1987 and 1994 - went further in the direction opposite to the wishes of Justice

54 We have seen that in reality the Court was swamped by cases concerning mostly the correct application and interpretation of ordinary laws, i.e., due-process issues, so that this emphasis turns out to be rather hollow.

55 See Ricardo Pozas Horcasitas, La democracia en blanco: el movimiento medico en MéXICO, 1964-1965 (Siglo XXI-UNAM, 1993).

56 In a speech delivered at the opening of a new CCC on October 28, 1968, Justice Martínez Ulloa expressed his belief that the reform had been well-thought out and represented the best of all possible solutions because it allowed for a reduction and transferal of the backlog and workload of the Court to Circuit Courts, which would have the final say in many cases, but in 
Canudas Orezza, i.e., further reducing the Court's jurisdiction over ordinary cases and determining its specialization in constitutional cases.

For the rest, the justice's speech delves into elevated and abstract philosophical questions, concerning the relations between power, security, and liberty. Like his two colleagues on the bench, Justice Canudas Orezza acknowledges the central role of the Federal Judiciary in the resolution of the complex issues raised by those relations. However, when dealing with the threats deriving from the exercise of power, he appears to be thinking rather of the perils originating in strong economic interests and invasive social powers, not State power. Thus, he appears to espouse the official ideology of the Mexican Revolution as a movement whose purported aim was to advance the rights of the worker, the peasant and ordinary citizens, by checking and controlling the appetites of the economic elite. On the other hand, there is again no clear or direct mention of the events at Tlatelolco two weeks before. Although it is hardly conceivable that Justice Canudas Orezza (and his two fellow justices) were not aware of them, it is also as unlikely that -in the context of his reflections on power, justice, liberty and safety - he would dare to openly and frontally criticize government repression. Political prudence would certainly discourage him from doing so and - coming, as he did, from the highest echelons of the same government - Justice Canudas Orezza would surely not have viewed things from that perspective.

In sum, the speeches we have examined confirm the idea that the Mexican Federal Judiciary seemed to operate largely detached from the political and social events of the moment, even though their authors undoubtedly had knowledge of and their own opinions regarding these events. The formal atmosphere surrounding adjudication fosters an insistence, on the one hand, on the central and indispensable role of the judicial organization in the resolution of social conflict and, therefore, in the maintenance of social peace, and on the other, on the higher - or at least different - level at which the application of the Constitution and the laws worked vis-à-vis the political and social struggles of the day.

"Judicial ideology", as attested by the speeches we have examined, stood, no doubt, in stark contrast to the perceptions of public opinion and Mexican society at large. There we would surely encounter a much lower degree of confidence in the justice system than the one boasted of by the members of the Supreme Court. However, the press notes published that year cannot provide us with an objective social perception of the courts. It is no secret that the majority of Mexican newspapers and magazines were politically biased and controlled. Hence, either the justice system would not appear as an object of scrutiny, or the image reflected there would not correspond to its effective social role.

a decentralized setting in the states. This was advantageous because if favored access to justice. See INFORME, supra note 22, 127-132. 
Nevertheless, we have access to two socio-legal studies that were carried out around 1968 and paint a picture of distrust and corruption in the justice system. The first one analyzed private-law conflicts in relation to the administration of justice. ${ }^{57}$ Its author describes Mexican legal culture as marked by the circumvention of open conflict (especially in rural or semi-rural areas), by distrust in the context of "substantial" interpersonal relations, by a lack of knowledge and awareness of legal rules, by very limited access to the courts, and generally, by the limited importance of the legal system for the emergence and resolution of disputes. ${ }^{58}$ As part of the investigation, a small survey carried out in Mexico City and the state of Nayarit asked respondents the following question: "Do you think that the courts treat all persons equally, or do you think that a case can be won only through money and connections?". Only 15 percent of respondents thought that everyone received a fair treatment before the courts, whereas 78 percent were inclined to think that only money and connections guaranteed a fair judicial treatment. Understandably, the latter percentage rose to 88 percent among respondents of the lower classes and it reached a full 99 percent of respondents in rural settings. Such percentage was also higher among those respondents who had had a conflict (57.6 percent of the total sample), regardless of whether they had filed a complaint (89 percent) or not (85 percent). ${ }^{59}$

Certainly, these answers are of limited usefulness in evaluating the performance of courts and judges in Mexico in the late 1960s, mainly because they do not distinguish between federal and state justice, or between the different branches of jurisdiction (criminal, civil, labor, etc.). They also need to be complemented by a series of more specific questions. They clearly reveal, however, the distance and the distrust of citizens towards the justice system, ${ }^{60}$ and it puts the optimistic and even pompous view prevalent among members of the judiciary into perspective.

The above results are further confirmed by another study, published in 1968, on the honesty (understood as a guarantee in enforcing the law and

57 Vokmar Gessner, Los conflictos sociales y La AdMinistración de Justicia En MÉXico (UNAM, 1984).

58 According to Gessner's estimates and even including judicial proceedings, about 80 percent of all private-law conflicts (civil, commercial, labor) between private parties would be terminated without implicit or explicit reference to the law and the legal order. Gessner, supra note 57.

59 Gessner, supra note 57, 91-92. Among those who had had a conflict, only 18.4 percent had filed a complaint before a court.

60 It is interesting to notice how little this perception seems to have changed in fifty years. The same question Gessner formulated was included in a national survey carried out in late 2014. 71.4 percent of respondents were inclined to answer that only "through money and connections can a case be won", 15.9 percent thought that "all persons are treated equally before the courts", 5.9 percent gave other answers, and 6.9 percent did not know or did not respond. See Héctor Fix-Fierro et al., Entre un buen arreglo y un mal pleito. Encuesta Nacional DE Justicia (UNAM, 2015). 
rejecting any political or economic influence in court decisions) in the administration of justice. ${ }^{61} \mathrm{~A}$ total of 240 interviews from a sample of judges and court officials, as well as attorneys, reveal a varying level of honesty in the various branches of jurisdiction. Administrative courts seemed to be the least dishonest, followed, in order of rising dishonesty, by the civil, criminal and labor courts. Evidently, there was a correlation between the socio-economic status of litigants and the level of dishonesty of the courts. It is less than surprising, therefore, that the higher levels of dishonesty and corruption were to be found in the criminal and labor courts whose clients belong to the lower economic strata of Mexican society. ${ }^{62}$

\section{The Trials and Tribulations of 1968}

The events of 1968 - and the repression used by the government in their wake - ultimately reached the Federal Judiciary, as judges had to decide on the criminal charges brought by federal prosecutors against the revolting students and other political dissidents. The "amparo" was frequently used to challenge the detention and the criminal proceedings resulting from the actions of the security forces. Professor Héctor Fix-Zamudio - a well-known expert in the field of the law of "amparo" - recalls that many law students would approach him and show him the "amparo" petitions they had filed with the federal District courts on behalf of their fellow students who had been arrested in the marches and protests. They complained that the judges would peremptorily dismiss them, implying that they were under political pressure to behave that way. Professor Fix-Zamudio would patiently explain to them that the dismissal had rather resulted from a flawed drafting of the complaint. He would also point out that freedom of assembly was granted in Article 9 of the Constitution of 1917 on the condition that no violent actions were committed. ${ }^{63}$ Therefore, it was not enough to be legally right vis-à-vis public authorities, but to realize that, for good or for ill, constitutional protection was only available if some demanding legal requirements and formalities were previously fulfilled.

The events of October 2 in the Plaza of the Three Cultures in Tlatelolco had more serious judicial consequences because the detention of many people present at the meeting that afternoon resulted in various criminal charges brought against them both before the federal judges and the courts of the Federal District. Newspapers informed, for example, that a local judge had sent 99 detainees (97 men and 2 women) to pre-trial detention. They had been charged with numerous crimes, such as robbery, violent destruction of publictransportation vehicles, damage to alien property, physical injuries, homicide,

61 Jorge A. Bustamante, La justicia como variable dependiente, in TEMAS Y PROBLEMAS DE LA ADMinisTRACiÓn DE JUSTiCia 13-44 (José Ovalle Favela, ed., 1982).

62 Ibid., $41 \mathrm{ff}$.

63 Fix-Zamudio, supra note 11, 193. 
use and collection of fire weapons, resisting arrest, criminal conspiracy, and the like. None of the detainees made bail. ${ }^{64}$

A federal District judge in Mexico City also sent 15 persons to pre-trial detention, after the Office of the Attorney General of the Republic (Procuraduria General de la República) had charged them with at least ten different federal crimes: robbery, criminal conspiracy, homicide, physical injuries, use and collection of fire weapons, damage to alien property, resisting arrest, kidnapping and attacks on general means of communication (one detainee was also charged with forgery and use of forged documents). Among them were some of the more visible leaders of the student movement: Sócrates Amado Campos Lemus, Pablo Gómez Álvarez, José Luis González de Alba, and Gilberto Guevara Niebla. ${ }^{65}$

Newspapers also recorded that, a few days later (October 26, 1968), 63 detainees were released from detention because the charges against them had been dismissed (58 were being prosecuted before several courts of the Federal District and 5 more faced charges before a federal judge). Three detainees were released on bail but remained on trial for the crime of sedition. ${ }^{66}$

Among the persons prosecuted before the federal courts in connection with the events of 1968 were prominent activists and politicians from the leftwing. Thus, for example, a well-known writer, José Revueltas (1914-1976), was charged with incitement to rebellion, criminal conspiracy, sedition, damage to alien property, attacks on general means of communication, robbery, looting, collection of fire weapons, homicide, and physical injuries suffered by agents of authority. In his statement before the federal prosecutor he accepted to be one of the leaders and figures inspiring the student revolt, but also that his main aim was the creation of an opposition political party that could participate - with an electoral reform - in election campaigns. He rejected violence as a means of political struggle, but also held that, ultimately, armed struggle was to be resorted to. ${ }^{67}$ Heberto Castillo (1928-1997), a respected engineer and entrepreneur, was also arrested and charged with the same crimes as Revueltas, presumably committed during his political activities since 1961 as a founder and member of the Movement for National Liberation (Movimiento de Liberación Nacional), which Castillo held to be fully authorized by the Constitution. ${ }^{68}$

In the end, several of the leaders of 1968 who had been convicted and sent to the infamous prison of Lecumberri were released at the beginning of the administration of President Luis Echeverría (1971), as a gesture of political

64 Lucio Cabrera Acevedo, la Suprema Corte de Justicia durante el gobierno del Presidente Gustavo Díaz Ordaz (1965-1970) 325 (SCJN, 2004).

65 Ibid., 326.

66 Ibid., 329.

67 Ibid., $331 \mathrm{ff}$.

68 Ibid., 339-341. 
reconciliation, but they had to shamefully accept both their unjust conviction and a voluntary exile for a few years.

Interestingly, the leaders of 1968 were not charged with the crime of "social dissolution". This crime had been incorporated into the Federal Criminal Code at the start of World War II, for the purpose of fighting sabotage and espionage by foreign or enemy agents, but once the war was over, it remained in the Code. After an amendment in 1951, it was used for prosecuting political dissidents. So, for example, the leaders of the 1958-1959 movement of railroad workers filed "amparos" against their long prison sentences, arguing that such crime was unconstitutional. The plenary session of the Court avoided taking a stance on this issue and quietly sent the "amparos" to the First Chamber, which denied the protection sought. Since at least five cases were decided in the same direction, the precedent became obligatory, and the Federal Judiciary further denied all subsequent "amparos" on the same issue. ${ }^{69}$

In 1968 there was already a strong doctrinal and public opinion against the political use of the crime of social dissolution. In fact, the six-point petition list of the student movement demanded the abolition of this crime. This may explain why the government decided not to file such charges. President Díaz Ordaz himself reacted to this climate in public opinion. In his State-of-the-Union address of September 1, 1968 (a month before the events of Tlatelolco), he emphatically denied the existence of "political prisoners" in Mexico, arguing that nobody had been prosecuted and convicted merely for expressing their political ideas and not for committing other material crimes. Nevertheless, he supported the idea of having the Congress review the issue. Although he made it clear that he personally disagreed with the possible suppression of the crime, he promised to immediately publish any decree passed by Congress, should it decide to abolish it. ${ }^{70}$ In July 1970, several deputies and senators introduced a bill in Congress for the abolition of the crime of social dissolution. A bicameral committee was formed for the purpose of carrying out public hearings on the issue. Finally, at the end of that year the bill was passed and President Díaz Ordaz signed it into law before leaving office. ${ }^{71}$ The amendment had the immediate effect of releasing all prisoners who had been convicted for social dissolution in the previous decade.

\section{Gonclusion}

How should we assess the behavior of the Mexican Federal Judiciary in connection with the political and social events of 1968? Certainly, we cannot assume that the Supreme Court and the Federal Judiciary had any possibility of making their decisions under conditions of full independence and autonomy

\footnotetext{
69 Ibid., 17.

70 INFORMES PRESIDENCIALES, supra note 50, 160-161.

71 Cabrera Acevedo, supra note 64, 369 ff.
} 
if we consider the wide range of political, legal, economic and organizational constraints affecting them. Therefore, a direct confrontation with presidential power was completely out of the question. On the other hand, we cannot believe that the Federal Judiciary merely behaved as a docile instrument in the hands of the Executive branch, subject to its direct command, though we may safely suppose that all manner of indirect pressure were made to bear on the federal judges, perhaps with the desired results.

The fact remains, however, that the sentences against the leaders of student and other political and social movements of the day can be severely criticized on the basis of standards that were already recognized and protected by the Constitution at the moment, as the leaders themselves made abundantly clear in their public statements. In order to understand how this came to be, we must realize that the situation and context of the Federal Judiciary was very complex. Its performance was contingent on multiple factors, such as the state of the legal order at the moment, the trajectory of judicial precedents and constitutional interpretations, the origins and profiles of federal judges, and particularly the reality of the criminal justice system, utterly dominated by the Executive, in such a way that the outcomes of criminal convictions in politically sensitive cases were something of a foregone conclusion.

Evidently, there was a need for strong courts committed to the effective protection of constitutional rights. For many of the reasons examined in this essay, the Federal Judiciary of 1968 was not able to fully provide that protection. Twenty years later, however, a new judicial reform started the process of transforming the Supreme Court into a court focused mainly on constitutional questions, and especially on the protection of fundamental rights. A few legal scholars had been promoting this transformation for many years, until President Miguel de la Madrid (1982-1988) found the idea appealing enough. ${ }^{72}$ On his recommendation, the Supreme Court formed an internal committee to examine the issue. The President introduced a bill for constitutional amendment prepared on the basis of the proposals made by the $\mathrm{Su}-$ preme Court, and the Congress of the Union and a majority of state congresses finally passed the reform in $1987 .{ }^{73}$ Accordingly, the final decision of all "amparos" that involved only the correct interpretation of ordinary statutes was conferred to the CCGs, whereas only those cases in which constitutional questions were still left open could be further appealed sent to the Supreme Court.

Interestingly, and in a context of intense political, economic, social and legal changes, the President did not encounter strong political obstacles to this kind of judicial transformation, one that would clearly confer more power on the Supreme Court, something that past presidents had studiously avoided. According to President De la Madrid's own words, the country already found itself in an era in which

72 Fix-Zamudio, supra note 11, 317-318.

73 Diario Oficial de la Federación, August 10, 1987. 
...a definitive step could be taken by limiting the jurisdiction of the Supreme Court of Justice to the interpretation of the Constitution, while the review of legality issues could remain in the hands of lower instances. Thus, it is possible to reduce backlog and obtain a more effective administration of justice. ${ }^{74}$

Further on, President De la Madrid emphatically argued that he had managed to restore the Supreme Court to its role as a constitutional court, ${ }^{75}$ i.e., the reform did not attempt to innovate. One could easily say that the Constitution of 1857 had already envisaged such a role for the Court. However, the development of the "amparo" in the last decades of the $19^{\text {th }}$ century had led to an attenuation of the constitutional role of the Supreme Court as a consequence of its increasing intervention in the review of ordinary judicial decisions. This development was far from dysfunctional for the authoritarian political regime that was built up from the 1930s onwards.

Although extremely important, the judicial reform of 1987 still did not manage to transform the Supreme Court into a genuine constitutional court. The judicial reform of December 1994 conferred the Court new powers of constitutional review, and at the same time altered and reduced its composition to resemble a constitutional court according to the European model. ${ }^{76}$ The effects of this reform have taken many years to fully unfold. It was not until 2007 that it was possible to identify a clear turn of the Court towards a more active role in the protection of fundamental rights. ${ }^{77}$

Had the Supreme Court of Justice acted in 1968 like the Court we have nowadays, it would have probably played a different role in the defense of constitutional order and fundamental rights, but then again, 1968 would not have become the mythical '68 of glorious memory.

74 Miguel de la Madrid, Cambio de rumbo. Testimonio de una Presidencia, 1982-1988, 717 (FCE, 2004).

75 Ibid., 842.

76 Héctor Fix-Fierro, Fudicial Reform in Mexico: What Next? in Beyond Common Knowledge. Empirical Approaches to the Rule of Law 240-289 (Erik G. Jensen y Thomas C. Heller, eds., 2003).

77 See Alberto Abad Suárez Ávila, The Mexican Supreme as a Protector of Human Rights, 4 Mex. L. Rev. 239-260 (2012). 


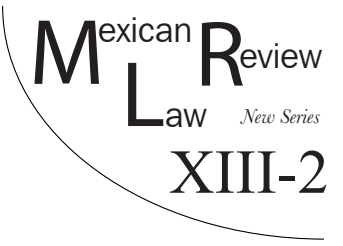

\title{
GAINING ACGESS TO JUSTICE: A SUBNATIONAL STUDY OF PUBLIC DEFENDER OFFICES IN MEXICO
}

\author{
Azul A. Aguiar-Aguilar*
}

\begin{abstract}
With the transition to democracy, Latin American countries have embarked on implementing judicial reforms to redesign justice-sector institutions and build up the rule of law in the region. Reform efforts included empowering the courts, granting political independence to the public prosecutor's office, professionalizing the public defender offices and implementing the accusatory criminal system in justice-sector institutions. To what extent are the reforms targeted at the public defender offices changing the way legal defense is provided? In this article, after discussing a theoretical framework that captures and operationalizes the concepts of a merit-based career system, an accusatory criminal justice system and effective legal representation, I examine the extent to which the changes of transitioning from an inquisitorial to an adversarial system and from a non-merit-based career system to a merit-based career system have affected the way legal counsel is provided at subnational public defender offices. To accomplish this, I provide both a de jure and de facto measures (indicators of reform implementation). To identify the de jure indicators, I consulted legal texts (constitutions and secondary lawe), and to gauge how the de facto indicators work, I relied on interviews with public defenders, reports and academic documents. I collected 50 interviewes with public defense attorneys from three Mexican states: Baja California Sur, Jalisco and Nuevo León. Findings from these states suggest that as reform implementation advances, public defenders have more tools to offer legal representation; more specifically, they are better trained, in addition to having higher salaries, a lower caseload per defender and increased access to forensic services.
\end{abstract}

KEYWORDS: Fudicial reform, public defenders, legal representation, accusatory criminal justice procedure, merit-based career system.

* Professor of Political Science in the Department of Sociopolitical and Legal Studies at the Western Institute of Technology and Higher Education (ITESO) in Guadalajara, Mexico. She holds a Ph.D. in Political Science from the University of Florence, Italy. Email: azulaguiar@ iteso.mx.

I am grateful for the valuable research assistance provided, at different points in time, by Andrea Aquino Rizo, Cristhy Alpuche Cabrera, Paul Villavicencio, Benjamín García and Luis Ángel Oseguera Farias. 
Esta revista forma parte del acervo de la Biblioteca Jurídica Virtual del Instituto de Investigaciones Jurídicas de la UNAM

REsumen: Con la transición a la democracia, los paises latinoamericanos introdujeron reformas judiciales para rediseñar las instituciones del sector justicia y construir el Estado de derecho en la región. Las reformas incluyeron aspectos como empoderar a las cortes supremas, otorgar independencia politica al ministerio público, profesionalizar la defensoría pública o implementar el sistema penal acusatorio en las instituciones del sector justicia. ¿En qué medida las reformas dirigidas a las defensorías públicas están cambiando la provisión de la defensa legal? En este trabajo, después de presentar los debates teóricos para capturar y operacionalizar los conceptos de sistema profesional de carrera, procedimiento penal acusatorio y representación legal efectiva, exploro cómo las reformas institucionales en materia de procedimiento penal y sistema profesional de carrera modificaron la forma en que los defensores públicos ofrecen defensa legal en el área penal. Para lograr esto, proporciono medidas tanto de jure como de facto (indicadores de implementación de reformas). Para identificar los indicadores de jure, utilizo textos legales (constituciones y leyes secundarias), y para evaluar cómo funcionan estos indicadores de facto, uso 50 entrevistas con defensores públicos en tres estados mexicanos: Baja California Sur, Jalisco y Nuevo León. Los hallazgos de estos estados sugieren que a medida que avanza la implementación de la reforma, los defensores públicos adquieren más herramientas para ofrecer una representación legal efectiva, en particular, están mejor capacitados, tienen salarios más altos, menos carga de trabajo por defensor y aumentan su acceso a los servicios forenses.

Palabras clave: Reforma judicial, defensores públicos, defensa legal, sistema penal acusatorio, servicio civil de carrera.

\section{TABLE OF CONTENTS}

I. INTRODUCTION.

II. Theoretical Debates on Griminal Procedure, the MeritBased Gareer System and Effective Legal Representation

1. Criminal Procedure

2. Professionalization and Merit-Based Career System.....

3. Effective Legal Representation

III. Case Selection and Data ......................................................... 45

IV. Legal Counsel in Subnational Public Defender Offices............. 46

1. Adversarial System.......................................................... 48

A. Baja California Sur ........................................................... 48

B. Jalisco............................................................................... 49

C. Nuevo León ................................................................... 50

2. Merit-Based Career System .................................................. 51

A. Baja California Sur ....................................................... 52

B. Jalisco................................................................................ 54

C. Nuevo León ………....................................................... 56 


\section{INTRODUCTION}

Legal representation is crucial for obtaining a fair trial. In many countries, the public defender offices (PDO) is in charge of guaranteeing the provision of this human right and providing those accused of committing a crime access to the courts. PDO services in criminal matters are mainly required by the most vulnerable sectors of society. Public Defender Offices (PDOs) are a channel to justice, especially (but not only) for the poor. As a matter of fact, in Mexico and developed countries like the United States, around 80 to 90 percent of the people facing felony charges have a public defender appointed to handle their cases. ${ }^{1}$ This fact is critical for PDOs, especially when they are underfunded and understaffed, as usually happens.

With the transition to democracy, Latin American countries embarked on judicial reforms to create or redesign justice-sector institutions and build up the rule of law in the region. One reform that swept across Latin America was changing the criminal procedural system from an inquisitorial to adversarial one. Administrative reforms aimed at improving the internal management of justice-sector institutions, particularly the professional profile of legal agents, were also introduced. These reforms touched on the performance of courts, the public prosecutor's office, the police, and the public defender offices: they were expected to improve access to and the administration/delivery of justice. In the case of public defenders, these reforms were intended to bolster the provision of effective legal representation. So, to what extent are these reforms changing the provision of legal counsel to defendants?

Effective legal representation is a complex concept that includes several rights that need to be provided and protected at each stage of the criminal justice process. For instance, there is the right to be presumed innocent, the right against self-incrimination or the right to not be held in pretrial detention during the process, i.e., to ensure that innocents do not end up in jail. ${ }^{2}$ Research has shown that effective legal representation varies due to several reasons which include institutional design, ${ }^{3}$ the defender being a "repeat

1 Velázquez quoted by Juan Carlos C. Razo, Por una Defensoría Pública Nacional, special number, Inst. Fed. De Def. Pública Rev. 11, 27 (2012); Amy Goodman, Gideon's Army: Young Public Defenders Brave Staggering Caseloads, Low Pay to Represent the Poor, Democracy Now!, January 24, 2013, at 1/24; John Pfaff, A Mockery of Justice for the Poor, N.Y. Times, April 29, 2016, at 4/30.

2 American Convention on Human Rights Relative to the Right to a Fair Trial art. 8, November 22, 1969, Chapter II Civil and Political Rights.

3 Ligia M. Madeira, Institutionalisation, Reform and Independence of the Public Defender's Office in Brazil, 8 (2) Br. Pol. ScI. Rev. 48, 69 (2014). 
player", 4 a sound budget for the PDO, forensic services, internal management, case assignment, regular training for defenders, caseload, or the defender's position and relation with other actors in the justice sector, such as public prosecutors and judges.

In this article, I explore the variations in the provision of effective legal representation in settings with and without the implementation of the abovementioned institutional reforms in two major areas: criminal procedural system and merit-based career system in subnational public defender offices. I contend that institutional reforms in these areas foster public attorneys' capacities and resources to provide effective legal defense. I use evidence from three Mexican states: Baja California, Jalisco and Nuevo León, which have introduced and implemented different levels of reform at the time the data for this work were collected. This makes it possible to observe the differences in how justice is provided by public defenders before and after the introduction of said reforms. My work seeks to contribute to prior research conducted on public defender offices in Mexico ${ }^{5}$ and in Latin America. ${ }^{6}$

In this article, I show the extent to which changes from an inquisitorial to an adversarial system and from a non-merit-based career system to a merit-based career system have affected the provision of legal counsel at subnational public defender offices. To accomplish this, I provide both de jure and de facto measures (indicators of the implementation of reforms). While legal provisions are important to improve the adversarial nature of the system and the professionalization of defense attorneys, it is crucial that they are fully operational; we gain little with embellished laws that are poorly enforced.

To identify the de jure indicators, I examined legal texts (constitutions and secondary laws), and to gauge how the de facto indicators work, I consulted interviews with public defenders, reports and academic documents. I collected 50 interviews with criminal defense attorneys and reviewed legal texts and reports from three Mexican states: Baja California Sur, Jalisco and Nuevo León. Findings from these states suggest that as the implementation of reforms advances, public defenders have more tools to offer effective legal representation.

4 Marc Galanter, Why the "Haves" Come out Ahead: Speculations on the Limits of Legal Change, 9 (2) LaW \& Society Rev. 95, 160 (1974); Humbert Kritzer and Susan Silbery (eds.), In Litigation: Do the "Haves" Still Come Out Ahead? 9 (1) Stanford Univ. Press. 95, 160 (2004).

5 Héctor Fix-Fierro \& Alberto Abad Suárez Ávila, Hacia una Defensa Pública de Calidad. El Nuevo Diseño Institucional de las Defensorías Públicas en las Entidades Federativas de la República Mexicana, 32 Cuest. Const. Rev. Mexicana De Der. Cn. 157, 200 (2015); Azul A. A. Aguilar, in La SeGURidad y La Justicia En Jalisco: Escenarios y Propuestas 352, 369 (Coecyt-Jal./Universidad de Guadalajara/Casede 2016); Angélica C. VÁzouez, Los Juicios Orales en el Estado de Morelos: Las Nuevas Prácticas (Facultad de Ciencias Políticas y Sociales-UNAM/Sitesa, 2017); Héctor Fix-Fierro \& Alberto Abad Suárez Ávila, El Servicio Profesional de Carrera en la Defensoría Pública en México, 25 Polít. Gob. 301, 338 (2018).

6 Catalina Smulovitz, Public Defense and Acess to Justice in a Federal Context: Who Gets What, and How in the Argentinian Provinces (Notre Dame University Press, 2019); Juan F. G. Bertomeu, Different Ways of Losing: Public Defenders (and Private Counsel) at the Supreme Court of Argentina, Law and Society Rev. 354, 390 (2020). 
In this article, I proceed in four additional steps. Section 2 presents a review of the literature on the three key concepts of this research: effective legal representation, the adversarial system and the merit-based career system. Section 3 walks through data and case selection. Based on the evidence of three local PDOs in Mexico, Section 4 is divided into three sub-sections: a) the operation of the adversarial criminal system; $b$ ) the merit-based career system; and c) effective legal defense. The final section draws conclusions, pointing out some of the implications of my findings on future research.

\section{Theoretical Debates on Criminal Procedure, the Merit-Based Career System and EfFective Legal Representation}

What allows criminal justice actors to expand their power or protect rights? Legal and political science scholars offer several explanations that range from judicial actors' strategic concerns,${ }^{7}$ ideology, ${ }^{8}$ ideas, beliefs and credible commitments ${ }^{9}$ to institutional factors. ${ }^{10}$ Other scholars also point out that multiple factors motivate judicial actors ${ }^{11}$ to extend their power or defend citizens' rights.

In this article, I follow an institutional approach to frame the legal protection of rights offered by public defenders. Institutions shape human interactions ${ }^{12}$

7 Jack K. L. Epstein \& Olga Shvetsova, The Supreme Court as a Strategic National Policymaker, 50 (1) Emory Law Journ. (2001); Gretchen Helmke, Gourts Under Constraints: Courts, Generals and Presidents in Argentina (Cambridge University Press, 2005); Jeffrey K. Staton, Judicial Power and Strategic Communication in Mexico (Cambridge University Press, 2010).

8 Jefrrey Segal \& Harold Spaeth, The Supreme Court and the Attitudinal Model Revisited (Cambridge University Press, 2002); Santiago Basabe-Serrano, Judges without Robes and Judicial. Voting in Contexts of Institutional Instability: The Case of Ecuador's Constitutional Court, 44 Latin American Studies Journ. 127, 161 (2012).

9 Lisa Hilbink, Judges beyond Politics in Democracy and Dictatorship: Lessons from CHILe (Cambridge University Press, 2007); Rodrigo Nunes, Ideational Origins of Progressive Fudicial Activism, 52 (3) Latin American Politics and Soc. 67, 97 (2010); Mathew Ingram, Crafting Courts in New Democracies. Ideology and Fudicial Council Reform in Three Mexican States, 44 (4) Comparatrve PoLIT. 439, 458 (2012).

10 Gretchen Helmke \& Julio Ríos-Figueroa (eds.), 'Introduction. Courts in Latin America'. In Courts in Latin America, eds. Helmke, Gretchen \& Julio Ríos Figueroa (Cambridge University Press, 2011); Javier Couso \& Lisa Hilbink, 'From Quietism to Incipient Activism. The Institutional and Ideological Roots of Rights Adjudication', in Ríos-Figueroa, Courts in Latin America.

11 Martín Shapiro, Courts: A Comparative and Political Analysis (University of Chicago Press, 1981); Diana Kapiszewski, Tactical Balancing: High Court Decision Making on Politically Crucial Cases, 45 (2) Law and Society Rev. 471, 506 (2011).

12 Douglas North, Institutions, Institutional Ghange and Economic Performance 03 (Cambridge University Press, 1990); James March \& Johan Olsen, Redescubriendo las instituciones. La base organizativa de la política (FCE, 1997); Bo. Rothstein, Political Institutions: 
and steer individual behavior; they establish limits and influence the actions of their community. In other words, rules guide the actions of individuals, particularly of those working in justice system institutions. Since this article seeks to assess the extent to which a change in formal rules produces a change in the way duties are performed within public defender offices, I expect to find actors working in justice sector institutions to adapt their behavior (even if poorly) to the rules introduced by the institutional reforms. That is, in a legalistic and formalistic environment like that of justice sector actors in Mexico, public defenders would first need a rule in order to act. Modifying behavior, however, does not occur instantly or without resistance. It takes time for the rule to be socialized, especially after incoming cadres come into the institution under the newly crafted rules. It is at this moment when institutions can more palpably shape behavior. This is the case, for example, of recently hired lower-ranking judges in Chile. ${ }^{13}$

The institutional approach I present is built on three variables, two independent ones: the adversarial criminal model and the merit-based career system; and a dependent one: effective legal representation. In the next section, I discuss the main theoretical ideas contained in these three concepts and, in the empirical section, I analyze both the formal rules of game (de jure) and how actors actually play or interact with those rules (de facto). This distinction between de jure and de facto is imperative and very simple: the first denotes formalized (i.e. constitutionalized) rules, while the second refers to how and by which means and actions those rules are enforced in practice. ${ }^{14} \mathrm{I}$ do not claim that institutions and institutional designs are the cure for all our ills, but only that they play an important role in how individuals behave.

\section{Criminal Procedure}

In Western countries two different types of criminal procedure have emerged: the inquisitorial system, characteristic of continental countries; and the adversarial tradition, distinctive of Anglo-American countries. The administration of justice in the continental tradition was inquisitorial, born "in the secret chambers of Romano-canonistic procedure, exemplified by the Inquisition". ${ }^{15}$

An Overview, in Robert E. Goodin and Hans-Dieter Kuingemann. A new handbook of PolitiCAL SCIEnce (Oxford University Press, 2002).

13 Couso and Hilbink, supra note 10.

14 For more information on de jure and de facto measures, see Ríos-Figueroa, Julio \& Jeffrey Staton, Unpacking the Rule of Law. A Review of Judicial Independence Measures, CELS 4th Annual Conference on Empirical Legal Studies Paper, (2009), available at https://papers.ssrn.com/ sol3/papers.cfm?abstract_id=1434234.

15 Mattei Ugo \& Luca G. Pes, 'Civil Law and Common Law: Toward a Convergence?', in The Oxford Handbook of Law and Politics, eds. Whittington Keith, Daniel Kelemen \& Gregory Caldeira 276 (Oxford University Press, 2008). 
Therefore, the process was conducted by and consolidated in the hands of a judge. In such a system, the legal process takes place between an "individual (the accused) and the State", ${ }^{16}$ a dual process - judge-claimant/defendantof conflict resolution. ${ }^{17}$ The Anglo-American tradition is typically adversarial, taking its "shape from a contest or a dispute: it unfolds as an engagement of two adversaries before a relatively passive decision maker (the judge) whose principal duty is to reach a verdict"; 18 it is a triadic model - judge/claimant/ defendant - of conflict resolution. ${ }^{19}$

Nowadays these sharp differences do not apply in real practice. Therefore, it is better to classify a legal system as predominantly adversarial or inquisitorial and leave the previous separation as a historical reference. ${ }^{20}$ Indeed, adversarial and inquisitorial models started to merge in continental Europe after the French Revolution when practitioners of the adversarial system saw fit to consider some of the classic features of the inquisitorial system such as the "creation of a professional police force and of a public prosecutor, to investigate the commission of crimes, compile evidence (and) conduct the criminal proceeding on behalf of the state". ${ }^{21}$ Furthermore, after the Second World War, when democratic regimes flourished, "the American legal system (became) the most influential legal system in the world". ${ }^{22}$ It spread throughout European and Latin American countries as a result of the wave of reforms to justice systems inspired by the United States model. As a matter of fact, criminal systems in Latin American democracies underwent a substantial change from inquisitorial to predominantly adversarial models or hybrid models in the third wave of democratization. ${ }^{23}$

The introduction of the adversarial model affected the performance not just of the judiciary, but also other institutions such as the police, the PDO and the public prosecutor's office (PPO). In terms of the PDO, the adversarial

16 John H. Merrymann, The Givil Law Tradition. An introduction to the Legal Systems of Western Europe and Latin America 127 (Stanford University Press, 1985).

17 Carlo Guarnieri, Pubblico Ministero e Sistema Politico 127 (Casa Editrice Dott. Antonio Milani, 1984).

18 Mirjan DamašKa, The Faces of Justice and State Authority. A Comparative Approach to the Legal Process 03 (Yale University Press, 1986).

19 Guarnieri, supra note 17, 127.

20 Thomas Weigend, Criminal Procedure: Comparative Aspects, in Encyclopedia of CRIME AND Justice, 444, 457 (MacMillan, 2002).

21 Merrymann, supra note 16, 127, 128.

22 Máximo Langer, From Legal Transplants to Legal Translations: The Globalization of Plea Bargaining and the Americanization Thesis in Criminal Procedure, 45 (1) Harv. Int. L. Journal (2004).

23 Mauricio Duce \& Andrés Baytelman, Evaluación de la Reforma Procesal Penal: Estado de una Reforma en Marcha (Universidad Diego Portales, 2003); Alberto M. Binder, La justicia penal en la transición a la democracia en América Latina, (November 23, 2019, 16:00), http://perso.unifr.ch/derecho penal/assets/files/anuario/an_1994_04.pdf; David Shirk, Criminal fustice Reform in Mexico: An Overviewe, III (2) Mex. L. Rev. 189, 228 (2011). 
system implied the introduction of rules and principles including oral litigation, alternative justice, publicity, immediacy, concentration and contradiction of proceedings and equality between the parties. ${ }^{24}$

Several Latin American scholars have shown that this type of system offers both the plaintiff and the defendant more tools to access a more transparent and expeditious judicial proceeding than the inquisitorial system used to offer. ${ }^{25}$ By analyzing the PDO, I demonstrate how the introduction of an adversarial criminal model affects the provision of effective legal representation. I expect to find that public attorneys have more tools to protect rights and offer effective counsel when working under a predominantly adversarial system. I do not claim that an adversarial model is good in itself or that PDOs could only solve their problems if this type of criminal procedure is implemented, but that in certain conditions and contexts (i.e. professionalized or well-financed institutions), the attributes of adversarial legal systems contribute to the provision of an effective defense better than the inquisitorial model does.

\section{Professionalization and Merit-Based Career System}

The professional profile of judicial actors plays a key role in the delivery of justice. No one is against the argument that the most qualified individuals should serve in office, whether that be the court, the prosecutor's office, the PDO or any other department in the justice realm. Some scholars argue that a meritocratic system lays the foundation to achieve the best professionalquality judges and separate justice from political influences. ${ }^{26}$ To select the best-qualified lawyers for justice institutions is then the first stone on which to build up a substantive rule of law. The European-continental legal tradition acknowledged this very well and thus crafted bureaucratic models to manage the process of judicial selection, training and evaluation. ${ }^{27}$

The meritocratic system in justice institutions is valuable not only for the way judges, prosecutors or defense attorneys are selected, but also for the ca-

24 Fix-Fierro \& Suárez Ávila, supra note 5; Aguiar-Aguilar, supra note 5.

25 Lydia Tiede Brashear, Chile's Criminal Law Reform: Enhancing Defendants' Rights and Citizen Security, 54 (3) Latin American Pol. And Soc. 65,93 (2012); Guillermo Zepeda Lecuona, Buenas PRÁCTICAS EN LA IMPLEMENTACióN Y OPERACIÓN DEL NUEVO SISTEMA DE JUSTICIA PENAL EN MÉXICO (USAID, 2014).

26 J. Andrew Crompton, Pennsylvanians Should Adopt a Merit Selection System for State Appellate Court Fudges, 106 (4) Dickinson Law Rev. 755,68 (2002); Giuseppe Di Federico, Recruttment, Professional Evaluation and Career of Judges and Prosecutors in Europe: Austria, France, Germany, Italy, the Netherlands and Spain (Lo Scarabeo, 2005); Thomas R. Phillips, The Merits of Merit Selection, 32 (1) Harv. Journ. Of Law \& Pub. Pol. (2009).

27 Carlo Guarnieri, Professional Qualification of the Fudiciary in Italy, France and Germany, GLOBAL Corruption Report, Transparency International (2007); Daniela Piana, Beyond Fudicial Independence: Rule of Law and Judicial Accountabilities in Assessing Democratic Quality, 9 Comparative SOCIOLOGY, 40-64 (2010). 
reer they are compelled to follow. This is particularly important in countries with recent authoritarian pasts where the patronage system was the most common way to fill positions in public institutions.

Concerning the professionalization of judicial actors, comparative legal studies have looked at the role played by judicial councils or commissions. ${ }^{28}$ The experience of several countries (France, Italy, Germany, Spain, Brazil and Mexico) shows that judicial councils are bureaucratic models of judicial governance, ${ }^{29}$ i.e., guardians of the professional profile of the officers and the performance of the institution. Councils engage in careful recruitment, training, evaluations and promotion processes. A core function of judicial councils is to regulate and manage the judicial career.

Professionalization within judicial councils implies the existence of a meritbased career system to guide the professional career of lower and mediumranking officers in justice-sector institutions. In cases such as France, Germany and Italy, judicial councils administer the career of judges and prosecutors with the aim of not only insulating them from political influences, but especially of professionalizing them and holding them accountable: judges and prosecutors undergo several evaluations before and after obtaining life tenure.

Public defenders are civil servants and as such need to follow a career system to avoid patronage and unprofessional profiles. A career system for public defenders implies an internal governance model, a systematized recruitment process, training, evaluation, promotion, salary protection, reallocation and a dismissal regulation. ${ }^{30}$

\section{Effective Legal Representation}

From the American Convention of Human Rights to the Charter of Fundamental Rights of the European Union, the African Charter on Human and Peoples' Rights, or the landmark decision of the United States Supreme Court in the case Gideon v. Wainweright, the right to effective legal representation is formally guaranteed, particularly in cases of low-income individuals accused of criminal offenses. With the aim of ensuring the right to a fair trial, countries and societies have developed different models to access justice that range from

28 Guarnieri, supra note 27; Nuno Garoupa and Tom Ginsburg, Guarding the Guardians: Fudicial Councils and Fudicial Independence, Public Law and Legal Theory, working paper n. 250 THE LAw School, The University Of Chicago (2008); Di Federico, supra note 26; Nuno Garoupa, Marian Gili, \& Fernando G. Pomar, Political Influence and Career Judges: An Empirical Analysis of Administrative Review by the Spanish Supreme Court, 9 (4)Journ. Of EmP. Legal Studies, 795, 826 (2012); Julio R. Figueroa, El Gobierno fudicial y Los Consejos de La Fudicatura, in Gobierno y Política EN México 49, 79 (Fontamara, IIJ-UNAM, TEPJF, 2019)

29 Piana, supra note 27.

30 Di Federico, supra note 26; Carl Russell Fish, 'The Civil Service and the Patronage', Russell \& Russell INC. (New York, 1963). 
public defender offices, to court-appointed counsel, to private lawyers hired by the government (contract-service system), to law school clinics or pro-bono centers (volunteer legal aid).

As stated above, effective legal defense is not an easy concept to grasp. Literature on legal representation points to two approaches: input and output oriented. On the one hand, the input-orientation posits that effective legal defense can be observed to the extent defense attorneys are "meeting with clients, contacting witnesses, conducting research, and carefully reviewing presentence investigation reports". ${ }^{31}$ On the other hand, the output orientation is more common in the literature and points to the outcome of the case as an indicator of the public defenders effectiveness. ${ }^{32}$ Comparing the results achieved by public defenders vis-a-vis private defense lawyers in criminal cases, output-orientation studies observe effective legal counsel in the rulings handed down: conviction or non-conviction, non-custodial sentences, probation rate, length of incarceration, life sentence, time established to serve at prison, among others. ${ }^{33}$ With the aim of better capturing the provision of effective legal counsel, Hartley, Miller and Spohn ${ }^{34}$ observe the effectiveness of public defenders by considering their performance at different stages in the criminal justice process: the bail decision, the plea bargaining decision, and two sentencing decisions (imprisonment and incarceration rate).

To empirically assess the concept of effective legal representation, one can also look at the defense attorney's perspective (input-oriented approach), i.e., what public defenders need in order to offer an adequate and effective defense. Informed by the theoretical proposal of Hanson, Ostrom, Hewitt and Lomvardias, ${ }^{35}$ international human rights treaties and the original empirical data collected in interviews with public defenders, I also highlight the following conditions as essential for an effective legal defense: a) free access to

31 Roger Hanson et al., Indigent Defenders Get the Job Done and Done Well. Study of the indigent Defense systems in nine U.S. JuRisdictions 51 (National Center for State Courts, 1992).

32 Dean J. Champion, Private Counsels and Public Defenders: A Look at Weak Cases, Prior Records, and Leniency in Plea Bargaining, 17 (4)Journ. Of Criminal Just. 253, 263 (1989); Floyd Feeney \& Patrick Jackson, Public Defenders, Assigned Counsel, Retained Counsel: Does the Type of Criminal Defense Counsel Matter, 22 (2) Rutgers Law Journ. 361 (1991); M. Hoffman, P. Rubin \& J. Shepherd Hoffman, An Empirical Study of Public Defender Effectiveness: Self Selection by the Marginally Indigent, 3 Ohio State Journ. of Criminal L. 223, 55 (2005); R. D. Hartley, H. V. Miller \& C. Spohn, Do You Get What You Pay For? Type of Counsel and its Effect on Criminal Court Outcomes, 38 Journ. OF Criminal Just. 1063, 1070 (2010).

33 Gerald R. Wheeler \& Carol L. Wheeler, Reflections on Legal Representation of the Economically Disadvantaged: Beyond Assembly Line Fustice Type of Counsel, Pretrial Detention, and Outcomes in Houston, 26 (3) Crime And Delinguency, 319, 332 (1980); Hanson, Hewitt, Ostrom \& Lomvardias, supra note 31,51 .

34 Hartley, Miller \& Spohn, supra note 32, 1065.

35 Hanson, Ostrom, Hewitt \& Lomvardias, supra note 31, 51. 
forensic services; b) a law degree and postgraduate studies; c) regular training; and d) caseload per defender.

To observe effective legal representation, I selected indicators of both the input-and output-oriented approaches for this work: caseload per defender, access to forensic services, and one stage of the criminal justice process: the outcome regarding pretrial detention. This last measure sheds light on how defenders perform their duty. Accordingly, one consequence of inadequate legal representation is the defendant going to pretrial detention, especially when it is the case of having committed minor crimes. While it is true that there are crimes for which pretrial detention is mandatory, in modern criminal procedures, non-serious criminal offenses should find other ways of punitive resolution and avoid pretrial detention. Public defenders play a crucial role in making this possible: they must keep their defendants from going to jail before a judge delivers a sentence. Like others, I assume that the defender is "an important influence in advocating for the release of the defendant"36 or in getting pretrial release with conditions, i.e., under supervision. Thus, the pretrial detention rate can portray the extent to which a public defender is doing her job well.

\section{Gase Selection and Data}

For this article I selected local PDOs in the states of Baja California Sur (BCS), Jalisco and Nuevo León. For the selection of cases I considered the stage of implementation of an adversarial system in the state. At the time fieldwork was conducted (March to April 2015), Baja California Sur was an instance of a state where the adversarial system was not implemented in any of its municipalities; Jalisco represented a case where the adversarial model was implemented in some municipalities; while Nuevo León was an example where the adversarial system was functioning in almost all its municipalities. ${ }^{37}$ This selection guaranteed variation across the cases and allowed for an assessment of how public defender offices performed before and after the implementation of the reforms. In the case of Baja California Sur and Jalisco, the adversarial system was not operating in the city or the metropolitan area where the fieldwork was conducted, even though there were differences among public defenders in those states, since in Jalisco, some municipalities have implemented the reforms.

I chose to interview public defenders in PDOs located in the capital cities or metropolitan areas because that is where most public defenders are concentrated. I focused on gathering interviews only from defenders working on

36 Hartley, Miller \& Spohn, supra note 32, p. 1065.

37 SETEC, Implementación de la Reforma Penal, (2015), available at http://wrerresetec.go b. $m x /$. 
criminal matters. I proceeded by contacting the head of Public Defender Offices in each state and explained the project in a formal letter. Once I had obtained their approval, I got in touch with the directors of criminal matters and, through them, I could establish contact and schedule appointments with the public defenders who wanted to participate in the project. ${ }^{38}$ For this work, a total of 50 personal interviews with public defenders were conducted: 13 out of 16 public defenders working in criminal matters in the capital city of Baja California Sur, 14 out of 38 in the metropolitan area of Jalisco, and 23 out of 120 in the metropolitan area of Nuevo León. Each interview lasted an average of 60 minutes.

The questionnaire contained 64 questions and was divided into three sections: 1) general working conditions at the public defender offices and daily work; 2) the professional profile of public defenders and the accusatory system; and 3) motivation, ideas and interests about being a public defender. For this article, I only used the data in Section 2; that is, 25 questions related, among other things, to how and when public attorneys were hired, what type of work contract they have, how the selection and appointment process was carried out, who can dismiss them from their position, whether they take training courses regularly and what type, whether the PDO offers them training courses, what type of material resources they have at their disposal to perform their job effectively, how much they are paid a month, whether they consider there is a merit-based career system or whether they think they are well-trained in the accusatorial system. In the next section, I make a qualitative analysis using the public defenders' individual answers to structure the argument on the extent to which practices have changed after the introduction of institutional reforms.

\section{Legal Counsel in Subnational Public Defender Offices}

In this section I first present a brief overview of the formal institutional setting in which public defender offices in BCS, Jalisco and Nuevo León perform their duties. Then, in the three sub-sections, I analyze the data collected from the interviews, constitutions, reports and documents in the three states where fieldwork was conducted.

The local constitutions and secondary regulations of BCS, Jalisco and Nuevo León indicate the attributes and the duties of the PDO. They also determine where the PDO is institutionally located, what type of institution it is, how it is organized, and which areas are under its jurisdiction, among others. Table 1 summarizes these issues.

38 It is worth noting that public defenders were very open to be interviewed and to tell their story about the conditions under which they were performing their jobs. 
Esta revista forma parte del acervo de la Biblioteca Jurídica Virtual del Instituto de Investigaciones Jurídicas de la UNAM

Table 1. The Public Defender's Office

in BCS, Jalisco And Nuevo León

\begin{tabular}{|c|c|c|c|}
\hline Characteristics & BCS & Falisco & Nuevo León \\
\hline Name & $\begin{array}{c}\text { Public Defender's } \\
\text { Office }\end{array}$ & $\begin{array}{c}\text { Social Prosecutor's } \\
\text { Office }\end{array}$ & $\begin{array}{c}\text { Public Defender's } \\
\text { Institute }\end{array}$ \\
\hline $\begin{array}{c}\text { Constitution } \\
\text { Organic Law }\end{array}$ & $\begin{array}{c}\text { Constitution } \\
\text { Organic Law }\end{array}$ & $\begin{array}{c}\text { Constitution } \\
\text { Organic Law } \\
\text { Regulation }\end{array}$ \\
\hline $\begin{array}{c}\text { Institutionalional } \\
\text { category }\end{array}$ & Executive Branch & Executive Branch & Executive Branch \\
\hline $\begin{array}{c}\text { Areas of defense } \\
\text { Griminal, civil } \\
\text { and family }\end{array}$ & $\begin{array}{c}\text { Criminal, civil, } \\
\text { family, commercial } \\
\text { and labor }\end{array}$ & $\begin{array}{c}\text { Criminal, civil, } \\
\text { family, commercial } \\
\text { and administrative }\end{array}$ \\
\hline
\end{tabular}

Source: Baja California Sur Constitution, 2014; Jalisco Constitution, 2014; and Nuevo León Constitution, 2009.

The PDOs in these three states are administratively part of the Executive branch and the governor freely appoints and dismisses top officials. In Baja California Sur, the PDO defends criminal, civil and family cases. Besides those types of cases, the Jalisco public defense attorneys also offer legal assistance in commercial and labor areas, while in Nuevo León these lawyers defend administrative cases, too (labor excluded). In this work, I only consider defenders working in the criminal field. Along these lines, the number of public defense attorneys in the PDOs of the capital city of Baja California Sur is 16 and of the metropolitan areas of Jalisco and Nuevo León is 38 and 120, respectively.

Table 2. Public Defense Attorneys

in Criminal Matters

\begin{tabular}{|l|c|c|c|}
\hline & BCS & Jalisco & Nuevo León \\
\hline No. of defenders & 16 & 38 & 120 \\
\hline Population & 251,871 & $4,434,878$ & $4,057,631$ \\
\hline No. of defenders per 100,000 inhabitants & 6.4 & 0.9 & 3 \\
\hline
\end{tabular}

SOURCE: Interviews with public defenders and information provided by PDOs; INEGI, 2010.

Considering the population of the metropolitan areas of Jalisco and Nuevo León, or the capital city in the case of Baja California Sur, there are about 6.4 defenders for every 100,000 inhabitants in Baja California Sur, 0.9 in Jalisco and 3 in Nuevo León. 
Esta revista forma parte del acervo de la Biblioteca Jurídica Virtual del Instituto de Investigaciones Jurídicas de la UNAM

\section{Adversarial System}

Since 2008, states have been required by the Mexican federal constitution to implement the adversarial system by 2016 . The three states analyzed here have introduced legislative changes to adopt the new model. According to Mexico's Technical Secretary of the Coordinating Council for the Implementation of the Criminal Justice System, ${ }^{39}$ Nuevo León introduced the adversarial system in 2006, well before the federal constitutional reform; Jalisco introduced constitutional changes and a few judicial districts started to operate under the new system in 2014; finally, BCS adopted the new system in 2013, but it did not start operating in some regions until 2016. In Nuevo León, the adversarial system was running in almost all the municipalities at the time this fieldwork was conducted. To what extent has the adversarial system been adopted, de jure and de facto, by the PDO and by public defense attorneys? The formal adoption of the rule has varied in the de facto operation of the adversarial system. Considering the indicators discussed in the theoretical debates on criminal procedure, Table 3 reports de jure (DJ) measures; that is, what legal texts state, and de facto (DF) measures, namely, public defenders' self-reported behavior regarding each indicator:

\section{Table 3. Adversarial System in Public Defender Offices}

\begin{tabular}{|l|c|c|c|c|c|c|}
\hline \multirow{2}{*}{\multicolumn{1}{|c|}{ Indicator }} & \multicolumn{2}{|c|}{ BCS } & \multicolumn{2}{c|}{ Falisco } & \multicolumn{2}{c|}{ Nuevo León } \\
\cline { 2 - 7 } & $D f$ & $D F$ & $D f$ & $D F$ & $D f$ & $D F$ \\
\hline Oral litigation & 1 & 0 & 1 & 0 & 1 & 1 \\
\hline Alternative dispute resolution & 1 & 0 & 1 & 1 & 1 & 1 \\
\hline Publicity & 1 & 0 & 1 & 0 & 1 & 1 \\
\hline Immediacy & 1 & 0 & 1 & 0 & 1 & 1 \\
\hline Concentration & 1 & 0 & 1 & 0 & 1 & 1 \\
\hline Contradiction & 1 & 0 & 1 & 0 & 1 & 1 \\
\hline Equality between the parties & 1 & 0 & 1 & 0 & 1 & 1 \\
\hline Total number of indicators found & $7 / 7$ & $0 / 7$ & $7 / 7$ & $1 / 7$ & $7 / 7$ & $7 / 7$ \\
\hline
\end{tabular}

DJ: De jure; DF: De facto.

Source: Baja California Sur Constitution, 2014; Jalisco Constitution, 2014; Nuevo León Constitution, 2009; LODP/BCS 2014; LOPS/JAL 2007; LIDP/NL 2013; Regulation of the LIDP/ NL 2011.

\section{A. Baja California Sur}

Even though the local constitutional reform took place in 2013, the adversarial system was not yet fully operational when the interviews were con-

39 SETEC, supra note 37. 
ducted. Public defenders, however, were aware of federal and local legislative changes, but they did not know this new system well and admitted that more training was required (see below), especially practical training such as how an oral trial can be performed. ${ }^{40}$ Litigation was still done through written files, and principles like publicity, immediacy, concentration and contradiction were absent during the trial.

Defenders acknowledged that the constitutional equality between the parties would most certainly be a very useful tool of the new system:

The new system will be horizontal. Judges, defenders and prosecutors will be at the same level, not like in the current inquisitorial system where the process is vertical: at the top you have the judge; in the middle, the prosecutor; and at the bottom, the public attorney. This is totally disproportionate and out of context (to protect) due process. ${ }^{41}$

Finally, defenders are familiar with alternative justice but they claimed that it was not widely used as a mechanism to resolve disputes: "Alternative justice is a new area and we do not use it frequently because we do not have much knowledge about how to implement alternative mechanisms of dispute resolution to the cases we have". ${ }^{42}$

\section{B. Falisco}

In Jalisco the adversarial system started operations in some state municipalities in 2014. Public defense attorneys affirmed that they knew the adversarial system and had been offered some courses on the rules and procedures of this new criminal model, $85 \%$ of the defenders claimed that practical training was needed: "We need more practice. I think we have received too much theory, but we still do not know how the system operates in practice". ${ }^{43}$ For instance, they did not know how to conduct oral arguments during a trial. Proceedings continued to be inquisitorial: there was no publicity, orality, immediacy or contradiction during the trials. In this sense, defenders argued that with the new system they hope will be "more transparency during the process and more access to resources to conduct investigations", ${ }^{44}$ but also "the judge will be present during the trial to solve the dispute between the parties. It will be different from the traditional system in which the judge only sits in his office and clerks do all the work, hear the parties and decide on cases". 45

40 Interview with Public Defenders 4 and 7, BCS (Mar. 2015).

41 Interview with Public Defender 8, BCS (Mar. 2015).

42 Interview with Public Defender 5, BCS (Mar. 2015), as well as interviews with Public Defenders 1, 3, 9, $11 \& 13$.

43 Interview with Public Defender 7, JAL (Mar. 2015).

44 Interview with Public Defender 4, JAL (Mar. 2015).

45 Interview with Public Defender 5, JAL (Mar. 2015). 
Public attorneys strongly believed that the adversarial model would radically change one of the most pervasive characteristics of the traditional inquisitorial system: the disparities between prosecutors and defenders.

I think the government (currently) does not devote as much attention to public defense as to prosecution. You can notice it simply by looking at the staff and our salaries. In the Public Prosecutor's Office, each prosecutor appointed to a court has two secretaries and a clerk. In my case at the Public Defense, it is only me as a defender and I do not even have an assistant and I earn less than a prosecutor... The adversarial system will correct these anomalies. ${ }^{46}$

Overall, public defense attorneys in Jalisco have taken more training courses on the new model than in BCS (but fewer than in Nuevo León), and claimed to make frequent use of some of its mechanisms, such as alternative justice, even when the adversarial system had not been introduced in the metropolitan area where they worked: ${ }^{47}$ "We are using alternative mechanisms of dispute resolution very frequently because our managers constantly require it from us in order to reduce the caseload". ${ }^{48}$

\section{G. Nuevo León}

The adversarial system was operating in almost all municipalities in Nuevo León (including the metropolitan area of the city where the interviews were conducted). Almost all public defense attorneys in Nuevo León affirmed that they knew the new system procedures very well and especially recognized their advantages: "the new criminal procedure is more expeditious than the traditional (inquisitorial) one". ${ }^{49}$ Even when several disparities persist in the judiciary, the public prosecutor's office and the public defender office, ${ }^{50}$ public defenders also claim that:

Currently, judges, prosecutors and defenders have more equal conditions than they did under the past inquisitorial system. ${ }^{51}$

Now, our salary conditions are equal to that of prosecutors'; that constitutional premise has operated very well. However, we do not have equal material conditions (cars, gasoline) to conduct our investigations. ${ }^{52}$

\footnotetext{
46 Interview with Public Defender 5, JAL (Mar. 2015).

47 This is also because Jalisco passed its first Alternative Justice Law in 2007 and the Institute of Alternative Justice started to work in 2011.

48 Interview with Public Defender 6, JAL (Mar. 2015).

49 Interview with Public Defender 9, NL (Apr. 2015).

50 Interview with Public Defenders 11, 12 \& 17, NL (Apr. 2015).

51 Interview with Public Defender 13, NL (Apr. 2015).

52 Interview with Public Defender 3, NL (Apr. 2015).
} 
Regarding their training in the new criminal accusatorial system, public defense attorneys were proud of their institution because the Professional Training Center (responsible for organizing training courses) was the only one of its kind in Mexico: "it is not to brag but, among PDOs in Mexico, ours is currently recognized as the most professionally trained for the new criminal model". ${ }^{53}$ From alternative mechanisms for conflict resolution to publicity, immediacy, oral litigation, concentration and contradiction during the trial, defense attorneys agreed that these procedures had helped them to provide a better defense. The new adversarial system "works much better. Procedures are simpler and faster; it is a cleaner, more transparent and less corrupt type of justice. Everything is faster without so much paperwork". ${ }^{54}$ Public defenders claimed that, since the reforms, their salary was equal to that of prosecutors' ${ }^{55}$

To conclude, the adversarial system has been introduced in all three states, but only works well in practice in the state of Nuevo León, where more progress has been made in its implementation. This is also so because, as stated before, the introduction of legislative changes took place earlier in this state and defenders have been working under the new system since 2006.

\section{Merit-Based Career System}

Since 2009 and then in 2013, public defender laws in the states of Nuevo León $^{56}$ and Baja California Sur, ${ }^{57}$ respectively, have specified the de jure existence of a public defender career system (PDCS). In the case of Jalisco, no law has stipulated the conditions for the operation of a public defender career system. Thus, Jalisco did not even have a de jure PDCS. Considering the indicators outlined in the theoretical section, the following table illustrates the extent to which de jure and de facto dimensions exist when talking about the PDCS.

\section{Table 4. Public Defender Career System in Baja California Sur, Jalisco and Nuevo León}

\begin{tabular}{|c|c|c|c|c|c|c|c|}
\hline \multirow{2}{*}{ Indicator } & \multirow{2}{*}{ Description } & \multicolumn{2}{|c|}{$B C S$} & \multicolumn{2}{c|}{ Jalisco } & \multicolumn{2}{c|}{ Nuevo León } \\
\cline { 3 - 8 } & & $D \mathcal{F}$ & $D F$ & $D \mathcal{F}$ & $D F$ & $D \mathcal{F}$ & $D F$ \\
\hline Council & Internal governance model & 0 & 0 & 0 & 0 & 1 & 1 \\
\hline
\end{tabular}

53 Interview with Public Defenders 3 \& 5, NL (Apr. 2015).

54 Interview with Public Defender 3, NL (Apr. 2015).

55 Interview with Public Defender 10, NL (Apr. 2015).

56 Ley de Defensoría Pública para el Estado de Nuevo León (Public Defender's Office Law for the State of Nuevo León). L.D.P.N.L, Art. 44, Feb. 6, 2009, MX.

57 Ley Orgánica de la Defensoría Pública del Estado de Baja California Sur [L.O.D.P.B.C.S] [Organic Law of the Public Defender's Office for the state of Baja California Sur], Art. 30, 31 de julio de 2017 (Mex.). 
Esta revista forma parte del acervo de la Biblioteca Jurídica Virtual del Instituto de Investigaciones Jurídicas de la UNAM

\begin{tabular}{|c|c|c|c|c|c|c|c|}
\hline \multirow{3}{*}{ Indicator } & Description & \multicolumn{2}{|c|}{$B C S$} & \multicolumn{2}{c|}{ Falisco } & \multicolumn{2}{c|}{ Nuevo Lé́n } \\
\cline { 2 - 8 } & Of & $D F$ & $D f$ & $D F$ & $D f$ & $D F$ \\
\hline \multirow{4}{*}{ Recruitment } & Open and public call & 0 & 0 & 0 & 0 & 1 & 1 \\
\cline { 2 - 8 } & Written and oral exams & 0 & 0 & 0 & 0 & 1 & 1 \\
\cline { 2 - 8 } & On-the-job training & 0 & 0 & 0 & 0 & 1 & 1 \\
\cline { 2 - 8 } & Collegial appointment & 0 & 0 & 0 & 0 & 1 & 0 \\
\hline \multirow{2}{*}{ Training } & Regular courses & 1 & 0 & 0 & 0 & 1 & 1 \\
\cline { 2 - 8 } & Free and mandatory & 1 & 0 & 0 & 0 & 1 & 1 \\
\hline \multirow{2}{*}{ Evaluation } & $\begin{array}{c}\text { Fulfill professional } \\
\text { requirements }\end{array}$ & 1 & 0 & 0 & 0 & 1 & 1 \\
\hline \multirow{2}{*}{ Salary } & Fixed & 1 & 1 & 0 & 0 & 1 & 1 \\
\cline { 2 - 8 } & Equal salary per rank & 1 & 1 & 0 & 0 & 1 & 1 \\
\hline \multirow{2}{*}{ Promotion } & Different ranks & 0 & 0 & 0 & 0 & 1 & 0 \\
\hline \multirow{2}{*}{ Reallocations } & $\begin{array}{c}\text { Based on defenders' } \\
\text { capacities }\end{array}$ & 0 & 0 & 0 & 0 & 0 & 0 \\
\hline \multirow{2}{*}{ Dismissal } & Infringement of rules & 1 & 1 & 1 & 1 & 1 & 1 \\
\cline { 2 - 8 } & Collegial removal & 0 & 0 & 0 & 0 & 0 & 0 \\
\hline \multicolumn{2}{|c|}{ Total number of indicators found } & $6 / 14$ & $3 / 14$ & $1 / 14$ & $1 / 14$ & $12 / 14$ & $10 / 14$ \\
\hline
\end{tabular}

DJ: De jure; DF: De facto.

SOURCE: LODP/BCS 2014; LOPS/JAL 2007; LIDP/NL 2013; Regulation of the LIDP/NL 2011. Interviews with public defenders in BCS, Jalisco and Nuevo León.

\section{A. Baja California Sur}

Concerning the dejure existence of a PDCS, I found 6 of 14 indicators. The Organic Law of the Public Defender's Office in BCS (LODP/BCS) states that calls to fill positions in the PDO can be open or closed, ${ }^{58}$ i.e., it can be for the general public or for a previously selected pool of candidates. The law contains specifications regarding the appointment procedure, ${ }^{59}$ which is carried out by the head of the office. Training, promotions ${ }^{60}$ (Art. 34), remuneration, ${ }^{61}$ evaluations and dismissals ${ }^{62}$ are also stipulated. This law, however, does not point to anything regarding written and oral exams, a period of on-the-job training or transfers. Finally, it is worth noting that Article 31 of the LODP/BCS is in itself conflicting: it states that the career service includes positions de confianza for public defenders, legal advisors, and public defenders' regional coordina-

\footnotetext{
58 Supra note 57, Art. 32.

59 Supra note 57, Art. 33.

60 Supra note 57, Art. 34.

61 Supra note 57, Art. 35.

62 Supra note 57, Arts. 36 \& 37.
} 
tors, among others. In Mexico this type of position grants top officials (within or outside the institution) the opportunity to appoint and dismiss employees discretionally.

The de facto existence of a PDCS differs from the de jure dimension. Only 3 out of 14 indicators were present. According to all interviewees, there was no professional career system in operation. For instance, most public defenders earned a position in the PDO only because they sent their resume to the head of the office, performed some type of social service or unpaid internship in the institution or, sometimes, received help from a friend in the government. Their selection process included an interview and, in some cases, a generalknowledge exam:

I was informed that the public defender's office required personnel. So, I presented my application, I fulfilled all the requirements and I entered the institution as an unpaid intern and later I obtained my post. ${ }^{63}$

In my case, I took a general knowledge exam to get a position, but I was also backed by a friend working in the government. ${ }^{64}$

I left my job application at the public defender's office and when they called me, I first came to work as an unpaid intern for 8 months. ${ }^{65}$

I simply left my job application. ${ }^{66}$

Public defenders affirmed that since the introduction of the adversarial system, they had received more training in the past years and had been invited by other institutions - the judiciary or the SETEC - to take courses on oral trials. ${ }^{67}$ The local judiciary offered some of those courses for free. However, there was generally a fee. Additionally, training courses were not compulsory. ${ }^{68}$ Most defenders admitted that more training was needed.

To be honest, the institution had not offered us many courses; those that we have taken are organized by the local judiciary or the Cultural Center of the Supreme Court. ${ }^{69}$

Since the reforms to criminal procedure took place, the institution has offered us several courses, but I believe they are not enough, and we need more training. ${ }^{70}$

As reported by public attorneys, no system of promotion was in place and some of them thought that "nobody gives your work any merit". ${ }^{71}$ Profes-

63 Interview with Public Defender 1, BCS (Mar. 2015).

64 Interview with Public Defender 4, BCS (Mar. 2015).

65 Interview with Public Defender 7, BCS (Mar. 2015).

66 Interview with Public Defender 10, BCS (Mar. 2015).

67 Interview with Public Defender 3, BCS (Mar. 2015).

68 Interview with Public Defenders 2 \& 5, BCS (Mar. 2015).

69 Interview with Public Defender 3, BCS (Mar. 2015).

70 Interview with Public Defender 5, BCS (Mar. 2015).

71 Interview with Public Defender 13, BCS (Mar. 2015). 
sional evaluations were non-existent. Relocations from one area to another were based on institutional needs, without considering the defender's professional profile. All defenders agreed that the reasons for removals were related to a breach of law; however, dismissals were mostly effected only by the head of the office. Finally, the Baja California Sur PDO offered its attorneys a salary that was equal and fixed for same-ranking members, even though it was very low: an average $\$ 530$ USD monthly. According to the data provided by Suárez and Fix, public defenders in BCS were among those who received less than the average (\$720 USD) salary for local public defenders in Mexico. ${ }^{72}$

\section{B. Falisco}

The Organic Law of the Public Defender's Office in Jalisco (LOPS/JAL) does not contemplate a PDCS. As a matter of fact, I found only 1 of the 14 attributes of a career system. The LOPS specifies that the appointment and dismissal of a public defender is the responsibility of the head of the office. ${ }^{73}$ Nothing is said about open public calls to fill positions, on-the-job training, promotions, remuneration, evaluations or transfers. The law does not point at the organization of free regular courses, but claims that the public defender deputy prosecutor must present the head of the office with an "Annual Planning Program" 74 of the courses to be offered. As pointed out by Suárez Ávila and Fix, "the absence of provisions that regulate the Merit-Based Career System is a significant deficiency that undermines the constitutional mandate and the institution's perspectives of further development". ${ }^{75}$

As claimed by public defense attorneys in Jalisco, no PDCS was running at the time. As a matter of fact, only 1 of the 14 indicators was found. Regarding recruitment, defenders argued that it varied. In 2007, the PDO was transferred from the local judiciary to the executive branch. Hence, public defense attorneys that joined the institution prior to 2007 participated in a public call and took exams. But for those that came after, their appointment process was mainly due to having done a period of unpaid internship in the institution, taking psychological and legal tests, and having a friend in government:

I was accepted in the public defender's office for an unpaid internship and later I got the opportunity to hold a post. Of course, before being formally hired I taken various exams. ${ }^{76}$

72 Suárez Ávila \& Fix-Fierro, supra note 5, p. 321.

73 Ley Orgánica de la Procuraduría Social, Estado de Jalisco [L.O.P.S.] [Organic Law for the Public Defender's Office for the State of Jalisco] Art. 9, n. VIII; and Art. 44, 16 de enero de 2007 (Mex.).

74 Supra note 73, Art. 14.

75 Suárez Ávila \& Fix-Fierro, supra note 5, p. 311.

76 Interview with Public Defender 4, JAL (Mar. 2015). 
I obtained a post, how can I say, not through a recommendation but because I was working on the government transition team and then I joined the public defender's office. ${ }^{77}$

I passed an exam. I participated with other two lawyers and my score on the exam was the highest. That is why I was hired. ${ }^{78}$

Public defense attorneys' different appointment processes also had implications on their salaries. Even when they had a position at the same rank, those who were hired when the PDO belonged to the judiciary had higher salaries - circa USD $\$ 960$ - than those that were recruited after the institution was moved to the executive branch — circa USD $\$ 530$ - ${ }^{79}$ The PDO by itself does not organize training courses on a regular basis, but allows public defenders to attend those offered by other authorities, especially after the criminal reform was approved. One defender indicated, however, that attending courses sometimes proved to be difficult given their heavy workload. ${ }^{80}$ Overall, they had received training after the approval of criminal reform but claimed more training was needed:

We receive training courses especially to be updated in the new criminal process and the delivery of justice in criminal matters. For instance, we have taken courses on oral trials. In any case, I believe more training is needed. ${ }^{81}$

We take approximately two training courses per year. These courses are in criminal law, constitutional law or oral trials. The frequency is two per year and the length ranges from 3 to 6 months and there are others that last up to a year. Some courses are optional, but others are mandatory and we have to attend them. ${ }^{82}$

The last course we took was on oral trials in October 2014. The courses are free of charge and are organized by the University of Guadalajara, the public prosecutor's office, the SETEC, but to tell the truth, there are not many from the public defender's office. ${ }^{83}$

Concerning evaluations, there were no established mechanisms to carry them out. Furthermore, public defenders acknowledged that no promotion mechanisms existed either. In the experience of the defenders, transfers from one area to another were based on institutional needs. Indeed, one interviewee pointed that being moved to "the criminal area in Puente Grande penitentiary is a type of punishment". ${ }^{84}$ Finally, dismissals occurred when the law was broken.

77 Interview with Public Defender 5, JAL (Mar. 2015).

78 Interview with Public Defender 9, JAL (Mar. 2015).

79 Interview with Public Defender 7, JAL (Mar. 2015).

80 Interview with Public Defender 13, JAL (Mar. 2015).

81 Interview with Public Defender 4, JAL (Mar. 2015).

82 Interview with Public Defender 8, JAL (Mar. 2015).

83 Interview with Public Defender 13, JAL (Mar. 2015).

84 Interview with Public Defender 7, JAL (Mar. 2015). 


\section{G. Nuevo León}

The Organic Law of the Institute of the Public Defender (LIDP/NL) and its regulations (RLIDP/NL) are the main legal framework for the PDO in Nuevo León. De jure the PDO presents 12 out of 14 indicators. In this vein, the RLIDP stipulates that the head of the office invites the Advisory Council - formed of citizens with honorary membership - to conduct the selection, appointment and promotion process of public defenders. ${ }^{85}$ Candidates must pass theoretical and practical exams on legal matters and undergo a period of on-the-job training to improve their abilities to work under an adversarial system. ${ }^{86}$ There is a defender's school called Professional Training Center. Besides, the head of the office is in charge of managing cooperation exchanges with universities, government authorities, and the judiciary in order to regularly train public defenders. ${ }^{87}$ Training courses are mandatory. ${ }^{88}$ Public defense attorneys' remuneration is fixed and equal among same-ranking members. Sanctions are linked to the non-fulfillment of professional requirements, such as not offering an adequate defense and are enforced by the Advisory Council. ${ }^{89}$ Finally, relocations are made to meet institutional needs and the removal of public defenders is decided by the head of the office. ${ }^{90}$

Defenders in Nuevo León acknowledged that the PDCS is fully operational. According to interviewees, 10 out of 14 indicators were present. All defenders in the PDO obtained a position there after passing practical and written legal exams. ${ }^{91}$ They confirmed the existence of a Professional Training Center, in charge of implementing an on-the-job training program for newly hired defenders, as well as personnel training courses. In the same vein, defenders were offered regular, mandatory and free-of-charge courses, ${ }^{92}$ as well as the opportunity (and money) to apply for a master's or $\mathrm{PhD}$ degree program ${ }^{93}$ in different universities. These results are consistent with the data provided by Suárez and Fix, who argued that "Nuevo Leon is the state with the highest rates of education" 94 among public defenders. Accordingly, defenders pointed out that:

85 Reglamento de la Ley de Defensoría Pública para el Estado de Nuevo León [R.L.D.P.N.L] [Regulations of Public Defender's Office Law for the State of Nuevo León], Art. 65, 68 \& 69; \& supra note 56, Art. 18, 6 de febrero de 2009 (Mex.).

86 Supra note 85, Arts. 66 \& 69.

87 Supra note 85, Art. 70.

88 Supra note 85, Art. 60.

89 Supra note 56, Article 41.

90 Supra note 85, Article 17, n. IV \& V.

91 Interviews with Public Defenders 1, 23, NL (Apr. 2015).

92 Interviews with Public Defenders 1, 23, NL (Apr. 2015).

93 Interview with Public Defender 4, NL (Apr. 2015).

94 Suárez Ávila and Fix-Fierro, supra note 5, p. 314. 
The institution requires us to take courses and organizes our schedules to attend them. Last year I took a 100-hour one about the new National Code. It was an intensive course from 9 am to 8 pm. ${ }^{95}$

During the year, the Public Defender's Professional Training Center constantly organizes courses on several topics, e.g., oral trials, amparo, civil or family law. Furthermore, the public defender's office also funds us $(66 \%$ and we pay the other $34 \%$ ) to study master's and $\mathrm{PhD}$ programs in national or international universities. ${ }^{96}$

We have training courses. In fact, we have the Public Defender's Professional Training Center which is very well equipped for the new system: we have an oral trial courtroom in the professional training area. By law, we must take at least 200 hours of training courses. ${ }^{97}$

Most public defenders, however, did not recognize the existence of a system of promotions: higher positions (General Offices) were few and the way they were assigned took into account not only the defender's professional profile but also his or her political relations since the head of the office and the governor were in charge of appointments. ${ }^{98}$ Some other defenders indicated, however, that there was a system of promotion in the different ranks $(\mathrm{A}, \mathrm{B}, \mathrm{C})$ of defenders. ${ }^{99}$ The salary was fixed and equal among same-ranking members. ${ }^{100}$ Additionally, their remuneration was around $\$ 2,100$ USD per month. Reasons for relocation were based on institutional needs: defenders were sent where they were needed. ${ }^{101}$ Finally, all public defenders agreed that dismissals occurred because of an infringement of the law; for instance, when a public defense attorney asked for money in exchange for services rendered. ${ }^{102}$

To conclude, a PDCS exists both the jure and de facto in Nuevo León, while in BCS it exists only de jure but not de facto. Finally, in Jalisco there is no PDCS either de jure or de facto.

\section{Effective Legal Defense in BCS, Falisco and Nuevo León}

The public defender offices in the three states are formally charged with providing free legal counsel and protecting defendants' due process and human rights. ${ }^{103}$ As argued in the theoretical part, one way to observe effective

\footnotetext{
95 Interview with Public Defender 1, NL (Apr. 2015).

96 Interview with Public Defender 3, NL (Apr. 2015).

97 Interview with Public Defender 14, NL (Apr. 2015).

98 Interview with Public Defender 3, NL (Apr. 2015).

99 Interview with Public Defender 5, NL (Apr. 2015).

100 Interview with Public Defender 5, NL (Apr. 2015).

101 Interviews with Public Defenders 10, 23, NL (Apr. 2015).

102 Interviews with Public Defenders 1, 23, NL (Apr. 2015).

103 See Art. 19, letter A, part VIII, BCS Constitution; art 8, no. XX, art. 5, no. II, LODP/ BCS; Art. 7, part II, letter h, Jalisco Constitution; Art. 9, letter A, part IX, Nuevo León Constitution; Art. 10, no. VI, LIDP/NL.
} 
Esta revista forma parte del acervo de la Biblioteca Jurídica Virtual del Instituto de Investigaciones Jurídicas de la UNAM

legal representation is through the outcome of a case (output-oriented approach). Thus, we can look at the rate of pretrial detention, a measure that helps us to understand the de facto implementation of some crucial aspects of the adversarial criminal procedure in terms of the work performed by justice system actors, inter alia, public defenders.

Pretrial detention in Mexico can be determined in two different ways: a) at the request of the prosecutor given the danger the defendant may pose and the seriousness of the imputed crime; b) ex officio, by a judge in cases of violent crimes such as homicide and those related to organized crime. Despite institutional reforms aimed at reducing the use of pretrial detention, data show that it continues to be a very severe problem in Mexico. In 2016, around 40\% of inmates were awaiting trial, ${ }^{104}$ i.e., technically $40 \%$ of prisoners could be presumed innocent because a judicial decision had yet to be delivered. The situation at the subnational level is also critical and, in many cases, much worse than nationally. To what extent has pretrial detention varied since reforms were introduced at local levels? Is it possible to assert that the pretrial detention rates have shown no positive variation in contexts of no local reforms while they have fallen in jurisdictions where these reforms have been implemented? The following graph shows the extent to which pretrial detention varied in BCS, Jalisco and Nuevo León from 2006 to 2016:

\section{Graph 1. Pretrial Detainees at State Level (\% of Total Incarcerated Population)}

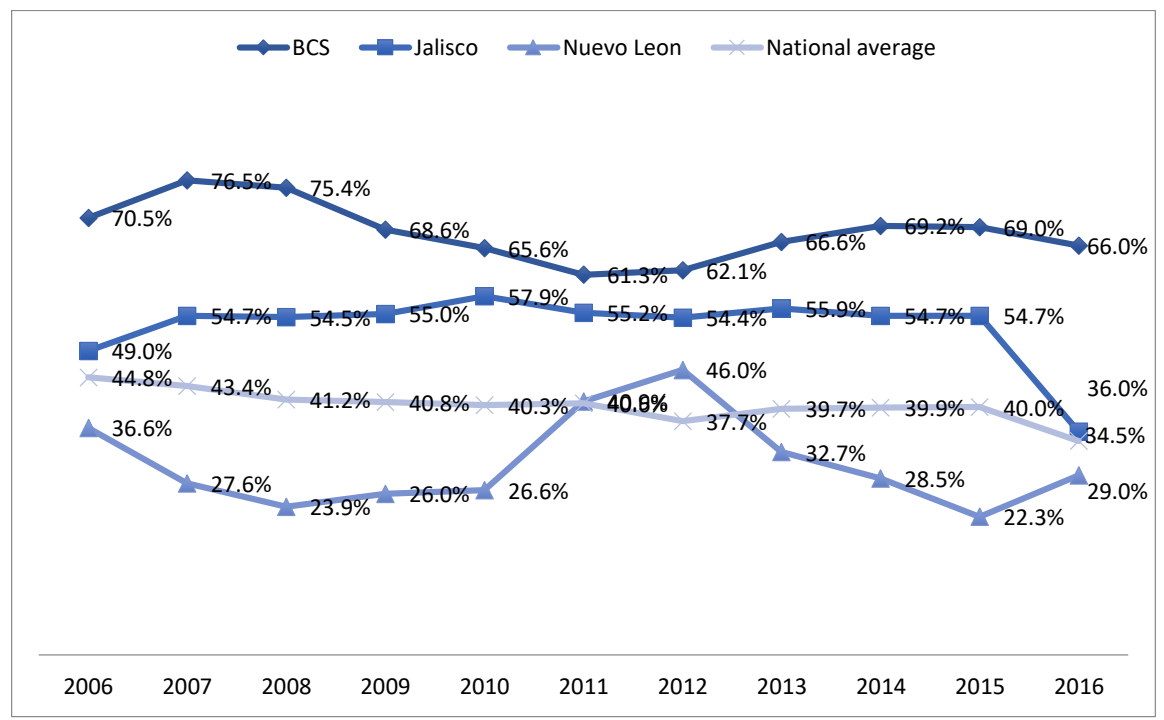

SOURCE: Data provided by Jurimetría, 2017. Zepeda Lecuona, 2017.

104 Guillermo Z. Lecuona, El Fenómeno de la Prisión Preventiva en México Bajo la Vigencia del Sistema de Justicia Penal de Corte Acusatorio, El sistema acusatorio en México (UNAM: Instituto de Investigaciones Jurídicas, 2017). 
From the graph we can say that BCS has the highest pretrial detention rate, followed by Jalisco and then by Nuevo León. The case of BCS is critical because, on average, $65 \%$ of its incarcerated population were awaiting trial. Additionally, the rate of pretrial detention in BCS and Jalisco was even higher than the national average, while in Nuevo León it was consistently lower compared to both other states and Mexico in general - only in 2011 and 2012 were the rates in this state higher than the national average but not higher than other states. The trends of pretrial detention show a pattern of decline nationally, in Nuevo León and in Jalisco (in the latter state, this was only for 2016) while BCS has maintained similar levels and in some years even the number of incarcerated population awaiting trial increased.

As discussed in the theoretical sections, other ways to approach public defenders' performance in legal representation is through their access to forensic experts' services and the caseload per defender (input-oriented approach). Access to forensic services is restricted in the three states. According to the 2015 National Census on State Government, Public Security and Penitentiary System, PDOs in BCS and Jalisco do not have personnel registered as forensic experts, while Nuevo León reported 19 experts. ${ }^{105}$ The PDO in BCS does not have its own forensic division and when services are needed, they are requested from the PPO. In Jalisco, defenders struggle to obtain certified and impartial forensic proof: "We need forensic services and we do not have them. We request them from Jalisco's Forensic Sciences Institute. It is supposedly a decentralized department, independent of the PPO, but in real practice they receive orders from this office (and) we end up asking the defendant's family to pay for private forensic experts". ${ }^{106}$ In Nuevo León, the PDO does not have its own forensic services division, as the local PPO does: "the Prosecutor's Office currently has around 600 forensic experts... In the PDO we have around 21. It is so out of proportion; but well in other states, Public Defender Offices don't have a single forensic expert appointed to the PDO". ${ }^{107}$

Regarding caseload, each defender has an average of 100 open cases in Baja California, 350 in Jalisco and 50 in Nuevo León per year. Putting this into perspective, a private attorney works normally with 30 to 40 open cases per year. The caseload per defender is excessive in Jalisco and less so, but still quite high, in Baja California Sur. Public defenders in Nuevo León have a less demanding workload. Defenders in the three states agreed that 30 to 40 cases per defender per year would be a proper amount of work, allowing them to offer effective legal representation. Working with such a heavy caseload, they argued, had a significant impact on their ability to provide a proper defense:

The truth here is that we sacrifice quantity for quality because it is a lot of work and we cannot devote much time to the cases. That's why we want the gover-

105 INEGI, 'Censo nacional de gobierno, seguridad pública y sistema penitenciario estatales

2015', (2015), available at https://wrwre.inegi.org.mx/programas/cngspspe/2015/.

106 Interview with Public Defender 7, JAL (Mar. 2015).

107 Interview with Public Defender 21, NL (Apr. 2015). 
nment to open more positions for public defenders, so that each defender can take the time that each case is due and get better results. ${ }^{108}$

We have a lot of work so we cannot provide an adequate defense. Why is it not an adequate defense? Because we do defend them, yes, we are there to assist them, to help them, but unfortunately, we cannot do our job properly. Why? Because having to attend four meetings displaying simultaneously... affects our attendance record too much. I think this affects a proper defense. ${ }^{109}$

If the number of cases is overwhelming, you cannot pay enough attention to each one of them. Sometimes your defendants come to you and you do not remember them, you have to ask them to provide you with context. In addition, we are short of time. It often happens that we cannot make it to the appointment we gave to discuss a case because we have to run to a preliminary hearing. ${ }^{110}$

Based on the evidence analyzed in this last sub-section, one can argue that public attorneys in Nuevo León are able to protect their clients' rights better than their counterparts in BCS and Jalisco are. Institutional reforms appear to be related to the differences between PDOs concerning access to forensic services and caseload per defender. Access to forensic services, even if restricted, is more readily available in Nuevo León since defenders in BCS and Jalisco do not have any forensic expert appointed to the institution. As stated by one public defender in Jalisco, they have to ask the defendant's family to pay for these services in order to have reliable evidence to defend a client. ${ }^{11}$ The caseload is lower in Nuevo León compared with that in BCS and Jalisco and this makes an important difference when one is protecting a person's rights, particularly because public defense attorneys will have the time to do investigations, take depositions or be present during the trial.

To conclude this section, if we consider both the input-oriented approach (access to forensic services and caseload per defender) and the output-oriented approach (pretrial detention) in the light of the evidence and the interviews in Baja California Sur, Jalisco and Nuevo León, their findings indicate that variations in the implementation of the reform plays an important role. As stated by interviewees, the criminal reform and the public defender career system provide a new institutional framework to better protect the rights of victims but especially those of defendants, who were mostly treated as guilty (and imprisoned) before any judicial decision could be reached.

The new (accusatorial) system improves the way justice is delivered because it has more tools to offer and adequate defense and we can use international treaties to protect human rights. Additionally, justice is prompter and more expeditious. $^{112}$

108 Interview with Public Defender 11, BCS (Mar. 2015).

109 Interview with Public Defender 5, JAL (Mar. 2015).

110 Interview with Public Defender 1, NL (Apr. 2015).

111 Interview with Public Defender 5, JAL (Mar. 2015).

112 Interview with Public Defender 11, BCS (Mar. 2015). 
Effective defense will be provided under the new accusatorial system because torture and solitary confinement of the defendant will fade away and the defendant will be presumed innocent until proved guilty. Not like now. Currently, they catch you, you are treated as if guilty and you have to prove your innocence. We are operating the other way around. I am fascinated by the new system. ${ }^{113}$

We received training courses on international human rights treaties... and, in general, I use the Tokyo Rules to guarantee that my defendants are not subjected to preventive imprisonment. ${ }^{114}$

As stated in the theoretical part, the attributes of these systems put public attorneys in a position where they can expand their power before the prosecutor and the judge, to be trained and prepared to defend their clients in oral trials or to use alternative dispute resolutions to avoid pretrial detention and convictions. As shown above, Nuevo León reformed its constitution in 2006 to introduce an adversarial criminal procedure i.e., two years before the federal constitutional reform, which took place in 2008, while the criminal system reforms in BCS and Jalisco were passed in 2013 and 2014, respectively. We can note a constant decline in pretrial detention, a reduction of open cases per defender and an increase in the number of forensic experts assigned to PDOs where institutional reforms have been adopted. Meanwhile, in states where these reforms are not present or are not fully running yet (BSC and Jalisco), the number of inmates without having been sentenced was found to be high, cases per defendant were also higher and PDOs did not account with their own forensic services.

\section{Conclusions}

The effective protection of rights comes from different institutions: national and international courts, prosecution services, human rights commissions, the police or the public defender offices. The role of this last institution in providing access to justice is crucial, especially for the most vulnerable sector of society: the poor and minorities who suffer from discrimination (indigenous or black people, for instance). Prisons from Mexico to Brazil or Argentina are full of poor people, who are oftentimes also innocent and whose only mistake was to be in the wrong place at the wrong time and not to have the money to hire a lawyer to defend them. Thus, the government appoints them one, but under institutional conditions hampering the defender from offering effective legal advice. Justice has an institutional, social and racial bias in these situations. This goes against the roots of the democratic rule of law and violates human rights.

Institutional arguments are powerful tools to explain behavior. In this work I analyzed how legal representation varies across non-reformed and reformed

113 Interview with Public Defender 7, JAL (Mar. 2015).

114 Interview with Public Defender 17, NL (Apr. 2015). 
Public Defender Offices. As suggested in the main expectations of this work, the case of Nuevo León shows that, as the implementation of rules advances, defenders tend to follow the rules in practice not only because they have a wider knowledge of those rules, but also because they feel helped or constrained by the rules they work under. In the cases of BCS and Jalisco, where rules have been introduced but not implemented - or worse, not even legally introduced as in the case of the public defender career system in Jalisco - defenders were found to have less knowledge, fewer abilities and scarcer incentives to use tools that open up the way they protect rights and offer an effective defense. These findings are also consistent with other works conducted in local public defender offices in Mexico. ${ }^{115}$ However, to fully ascertain this, future work would need to explore, at least, the following two paths.

The first would be to better estimate the role PDO financial support (and its consequences on a heavy caseload) might play in offering effective legal counsel. In several countries, "public defense finds itself starved of resources while facing impossible caseloads that mock the idea of justice for the poor". ${ }^{116}$ This assertion applies to Mexico's local PDOs, but it can apply just as easily to many Latin American countries. More funds to improve the legal representation of the impoverished are unquestionably needed, but to what extent would this solve the problems PDOs currently face in offering an effective legal defense? We need to evaluate the provision of more government resources for the PDO, especially in the face of its counterpart, the prosecution services, which in many cases happen to be better funded.

A second path worth exploring is the role of other institutions in the justice system. It is important to understand justice as a system in which the actions of other actors and institutions affect the outcomes produced in, for instance, pretrial detention. In this work, I focused on the role of public defenders in providing effective legal representation (i.e. avoiding that their client end up in jail). Future work should also estimate how and to what extent the police and prosecutors' performance also contributes to the protection of rights or lower pretrial detention rates by, for example, locking fewer people up and thus providing citizens genuine access to justice.

115 See Suárez Ávila \& Fix-Fierro, supra note 5.

116 Pfaff, 'A Mockery of Justice for the Poor'. 


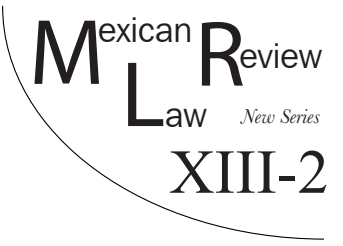

\title{
MUNICIPALITIES AS PART OF THE SYSTEM TO CONTROL CRIMINAL ASSETS IN MEXICO
}

\author{
Pedro Rubén Torres EstradA*
}

\begin{abstract}
Within a national system of control of criminal assets, the role of municipalities is strategic. According to their constitutional faculties, municipalities should develop and feed databases containing relevant information that contributes to the control of the criminal patrimonial and economic structures. An analysis of primary and secondary sources of information was used to identify the databases that are generated or that should be generated by the municipalities, considering the functions and powers that the constitution, laws, and regulations assign to each of the dependencies that integrate the municipal government. Although some municipal agencies keep track of their activities using databases, they do not have a structure that allows the exploitation of information. Moreover, some municipalities do not have structured public policies aimed at combating the patrimonial and economic structures of crime. Finally, municipalities are an important source of information that can contribute to law enforcement structures in the development of investigations aimed at weakening the financial and patrimonial structures of crime. This article showes the importance and utility of municipalities in the combat against assets generated by crime and the need to implement public policies intended to weaken the economic and patrimonial criminal structures. Currently, there are no previous studies on this subject in the national literature.
\end{abstract}

KEYWORDS: Operations with resources of illicit origin, municipal governments, databases, fight against crime-related assets, information analysis units.

Resumen: El papel de los municipios dentro de un sistema nacional de ataque de activos al crimen resulta estratégico, ya que estos, según sus competencias constitucionales, desarrollan y alimentan bases de datos que contienen información relevante que puede contribuir al ataque de las estructuras patrimonia-

* Researcher and Professor at the Escuela de Gobierno y Transformación Pública of the Instituto Tecnológico y de Estudios Superiores de Monterrey. Email: pedro.torres@tec.mx. We would like to thank the municipality of General Escobedo for all the information it provided us, and for their trust and support in the writing of this article. Special thanks to its municipal president (Clara Luz Flores) and its treasurer (Cesar Leija). 
Esta revista forma parte del acervo de la Biblioteca Jurídica Virtual del Instituto de Investigaciones Jurídicas de la UNAM

les y económicas de los delincuentes. Se realizó una recopilación de información de fuentes primarias y secundarias para identificar las bases de datos que generan o que deberían generar los municipios, teniendo en cuenta las funciones y atribuciones que la constitución, las leyes y los reglamentos le asignan a cada una de las dependencias que integran el gobierno municipal. Se pudo identificar que, si bien algunas dependencias municipales llevan el registro de sus actividades empleando bases de datos, estas no cuentan con una estructura que permita la explotación de la información; se identificó que los municipios no cuentan con políticas públicas estructuradas que se orienten al combate de las estructuras patrimoniales y económicas de la delincuencia. Los municipios son fuente importante de información que puede contribuir a las estructuras procuradoras de justicia en el desarrollo de investigaciones orientadas a debilitar las estructuras financieras y patrimoniales del crimen. Este trabajo muestra la importancia y la utilidad de los municipios en el combate contra los activos generados por la delincuencia y la necesidad de establecer políticas públicas orientadas al debilitamiento de las estructuras económicas y patrimoniales de las estructuras criminales. Actualmente, no existen estudios previos sobre el tema en la literatura nacional.

Palabras clave: Operaciones con recursos de procedencia ilícita, gobiernos municipales, bases de datos, ataque de activos de la delincuencia, unidades de análisis de información.

\section{Table of Contents}

I. INTRODUCTION

II. The Gurrent State of Public Policies in Municipalities.

III. Constitutional Municipal Faculties that Generate the Databases Required to Implement the Public Policies to Control Griminal Assets

IV. Municipal Organization and Databases................................... 70

V. Municipal Tax Information Analysis Areas.............................. 77

VI. The Unit's Structure and Basic Products................................ 78

VII. Conclusion: Implementation and Consolidation Risks of THESE NEW UNITS

VIII. ANNEXES

Information, information, information. I can't make bricks without clay... It is a mistake to theorize before obtaining information. Insensibly, one begins to distort facts to make them fit into theories instead of inserting theories into facts. 


\section{INTRODUCTION}

When we think about Transactions with Illegally Obtained Resources (ORPI's for their acronym in Spanish), we sometimes recall tax havens such as the Cayman Islands, Andorra or Switzerland, or complex transactions using virtual coins in the dark web. Although the above is part of the phenomenon and means used by criminals to move and spend the money obtained from their crimes, it is important to say that in Mexico the minority of criminals use this type of maneuvers, although they tend to be the ones that move larger amounts of money. ${ }^{1}$ The money laundered in Mexico in the most part results from three activities: (1) organized crime, (2) corruption, (3) tax evasion. ${ }^{2}$

Most criminals in Mexico depend on less complex mechanisms to use the money obtained from their crimes, such as the purchase of rustic agricultural or urban land by people who lend their names to carry out the operation as "figureheads". It is in this aspect where the role played by the states and municipalities represents an important part of the public policy machinery to control criminal assets and tools, both for organized and common crimes, in order to develop a national information system to control criminal assets.

This leads us to say that being aware of criminals' patrimonial and economic profiles is a key element of the security strategy and the justice system. In this sense, we believe that municipalities are the first barrier and institutional factor of the framework required to identify risks or generate alerts on possible money launderers in a given community. Clearly, municipalities cannot investigate this offence directly, but they can inform other federal or state entities of unusual behaviors or abnormal trends or patterns, just like banks, public notaries or jewelry stores do, and even more so since it is in the local public interest. ${ }^{3}$

Although formally it is a constitutional and legal obligation, ${ }^{4}$ municipalities normally have first-hand information on who is buying or registering (in case of straw men) land, houses or buildings; who is building or developing real es-

1 Proceso, México, virtual "paraíso" para el lavado de dinero: GAFI, Proceso, (Jan. 03, 2019), available at https://wwrw.proceso.com.mx/517149/mexico-virtual-paraiso-para-el-lavado-de-dinero-gafi.

2 Fatf \& Gafilat, Mutal Evaluation Report (2018).

3 Article 45 of the Federal Act for the Prevention and Identification of Transactions with Illegally Obtained Resources: "The Ministry and the Public Prosecutor's Office... may enter into agreements with the authorities that control the identification documents referred to in this article in order establish remote consultation systems". See, Ley Federal para la Prevención e Identificación de Operaciones con Recursos de Procedencia Ilícita [L.F.P.I.O.R.P.I] [Federal Act for the Prevention and Identification of Transactions with Illegally Obtained Resources] as amended, Diario Oficial de la Federación [D.O.F], 17 de octubre de 2012 (Mex.).

4 Article 10 of the General Files' Act: "Each regulated entity is responsible for organizing and preserving its files and operating its institutional system..."; Article 11: "The regulated entity shall organize, control and preserve the registry documents it produces, receives, obtains, acquires, transforms or possess in a homogeneous manner, in accordance with its faculties, com- 
tate properties; who is buying vehicles outside their usual pattern, who is making donations to public or private organizations, and who is making atypical investments in kind or in cash in political campaigns (some of this information must be public, such as donations to political institutions). ${ }^{5}$

When the money obtained from criminal activities becomes part of politics - for example when votes are bought through cash payments-, corruption increases and public institutions lose strength; ${ }^{6}$ this phenomenon translates into clientelism, reorientation of public policy and self-enrichment. ${ }^{7}$ Afterwards, those who invested in political campaigns go back to collect on their contributions, either in cash or in protection from the local authorities.

The municipalities cannot issue a warning based on testimonies without official and verifiable information. For this purpose, municipal authorities must order their patrimonial and fiscal information to be able to issue alerts that can activate the involvement of prosecutors' offices or other instances, such as municipal, state or federal tax authorities.

This article seeks to answer the following research question: Can the creation of Municipal Information Analysis Units help to fight criminal financial structures using the information bases generated by the municipalities?

Based on the corresponding constitutional faculties, this will be the method used to identify the databases that must exist in a municipality and the intelligence products that can be developed.

Municipal authorities will ask themselves what they gain from this measure, especially if they think that the illegal money that comes into their community fosters its economy or even activates it. However, the phenomenon of regions such as Michoacán and Tamaulipas demonstrate that the illegal money present in those states generates disputes and retaliations between groups, ${ }^{8}$ which,

petencies, skills or functions...". See, Ley General de Archivos [L.G.A] [General Files' Act], Diario Oficial de la Federación [D.O.F], 15 de junio de 2018 (Mex.).

5 Article 30 of the General Political Parties' Act: “(I) The reports they are under the obligation to present in terms of the provisions of this Law, the patrimonial standing of the political party... as well as the annexes that form an integral part of the above stated documents, list of donors and the amounts contributed by each one of them". See, Ley General de Partidos Políticos [L.G.P.P] [General Political Parties'Act], Diario Oficial de la Federación [D.O.F], 23 de mayo de 2014 (Mex.).

6 The General Electoral Institutions and Procedures Law, in its articles 443, 446, 445, states the type of offenses that can be committed by political parties, contenders, candidates, precandidates or candidates for elective office, as well as challengers and independent candidates. Additionally, in articles 9 and 15 the Electoral Offenses' General Law details the fines to be imposed on partisan officers or candidates that commit electoral offenses. See, Ley General de Instituciones y Procedimientos Electorales [L.G.I.P.E] [General Electoral Institutions and Procedures Law] as amended, Diario Oficial de la Federación [D.O.F], 23 de mayo de 2014 (Mex.).

7 Andreas Schedler, "El voto es nuestro". Cómo los ciudadanos mexicanos perciben el clientelismo electoral, 1 Rev. Mex. DE Soc. 57, 94 (2004).

8 According to the National Institute of Statistics and Geography - INEGI (2019), in 2012 Mexico City and the states of Mexico, Jalisco, Quintana Roo, Baja California, Nuevo León, 
in time, negatively affect the municipality in the form of violence and death, lack of investment, loss of land surplus value, ${ }^{9}$ lack of competitiveness ${ }^{10}$ and the creation of success stereotypes based on illegally obtained resources, which ultimately end up challenging and even subjecting municipal authorities. That is to say, it is a monster that turns against the municipality, as well as against most of its citizens and their assets.

\section{The Gurrent State of Public Policies in Municipalities}

In general terms, the Constitution of the United Mexican States and the National Institute of Statistics and Geography (INEGI for its acronym in Spanish) ${ }^{11}$ define municipalities as the basic political-administrative organization and division unit of the country's territory. Currently, Mexico is divided into 32 states and 2,457 municipalities. Oaxaca, Puebla and Veracruz have the largest number of municipalities, with 570 municipalities in Oaxaca, 217 in Puebla and 215 in Veracruz.

Mexican municipalities can be classified into four broad categories: rural, semi-urban, urban and metropolitan. ${ }^{12}$ Rural municipalities are characterized by developing activities related to the primary sector: livestock, agriculture, fishing and mining; the inhabitants of these municipalities tend to migrate to cities and towns where there is a more diversified economic activity looking for better jobs and income. They have less than 2,500 inhabitants.

Semi-urban municipalities are transitioning from rural to urban areas, combining agricultural and forestry activities with small industries, commerce and

Chihuahua and Morelos had the highest crime rates in the country, surpassing the national average. Likewise, the states of Chihuahua, Guerrero, Durango, Sinaloa and Tamaulipas concentrated the largest homicide rates in the country. See, INEGI, Tasa De Incidencia Delictiva Por Entidad Federativa De Ocurrencia Por Cada Cien Mil Habitantes, INEGI, (Oct. 28, 2019), https://wrerw.inegi.org.mx/temas/incidencia/.

9 The Centro de Estudios Económicos del Sector Privado states that insecurity, impunity and corruption affect the assets of individuals and companies, especially those of micro and small companies; this situation also limits economic growth, inhibits investment and welfare. See, Centro de Estudios Económicos del Sector Privado, Análisis Económico Ejecutivo, CEESP.ORG.MX, (Oct. 1, 2018), http://ceesp.org.mx/wp-content/uploads/2018/10/AEJE_01Oct18.pdf.

10 The Peace Index Mexico 2018, prepared by the Institute for Economics and Peace (2019), mentions that in 2017 violence in the country had an economic impact of at least 4.72 billion pesos (249 billion dollars), which amount to $21 \%$ of the national GDP. This impact is seven times greater than the education budget and eight times greater than public investment in health for the same year. See, Institute for Economics \& Peace, Índice de Paz México 2019, Sidney: Institute For Economics \& Peace; Vision Of Humanity (2019), http://indicedepazmexico.org/.

11 INEGI, Encuesta Intercensal 2015, INEGI, (Oct. 11, 2015), https://wrwre.inegi.org.mx/pro gramas/intercensal/2015/.

12 Miguel Cervera Flores, J. Walter Rangel Gonzalez, Distribución de la Población por Tamaño de Localidady su Relación con el Medio Ambiente, Dirección General de Estadísticas Sociodemográficas, INEGI, (February, 2015), https://wrew.inegi.org.mx/eventos/2015/Poblacion/doc/p-WalterRangel.pdf. 
services; these municipalities have a population that ranges between 2,500 and 15,000 inhabitants.

Urban municipalities are characterized by the presence of highly developed companies and small and medium-sized industries that foster their development. They have a population between 16,000 and 699,999 inhabitants, so they have more complex needs and demands in terms of public services, economic development and public safety, among others.

Finally, metropolitan municipalities are those integrated by other urban municipalities and have the characteristics of mega cities (they have an average population of 700,000 to 1 million inhabitants). Given their geography, they are close to state capitals, with political and administrative dimensions that makes them share problems, needs and interests. ${ }^{13}$ Currently, Mexico has 74 metropolitan areas. ${ }^{14}$

Taking the above into consideration, municipalities with urban characteristics can implement a Fiscal Information Analysis Units with the characteristics that we will mention further on.

\section{Constitutional Municipal Faculties \\ that Generate the Databases Reguired to Implement the Public Policies to Gontrol Criminal Assets}

In accordance with article 115 of the Constitution of the United Mexican States, municipalities are autonomous and have a governmental capacity in all matters that the Constitution grants them; ${ }^{15}$ that is to say, they do not require any mediation to exercise the faculties allocated to them in the Magna Carta. The Mexican federal system applies a faculty formula between government orders rather than a hierarchy formula, such as the one in North America's federalism.

Therefore, in Mexico the different levels of government have the same hierarchy and, in a state of constitutional normality, it depends on the faculty of each level to determine which one has predominance over a specific function. In sum, municipalities can decide and be responsible for themselves and, hence, for everything related to the databases derived from these faculties. These databases are the raw material required to develop the intelligence products proposed by the public policy.

13 For more information regarding metropolitan areas please refer to annexes 1, 2, 3 and 4. See, Conapo, Inegi, Sedatu, Segob, Delimitación de las zonas metropolitanas de México 2015 (2015).

14 For information regarding the Delimitation of Metropolitan Areas in Mexico please refer to Annex 5. See, Conapo, Inegi, Sedatu, Segob, Delimitación de las zonas metropolitanas DE MéXICO 2015 (2015).

15 Pedro Torres, la Autonomía Municipal y su Garantía Constitucional Directa de Protecaión. Estudio Comparado de los Supuestos Español y Mexicano 282, 283 (Universidad Nacional Autónoma de México, 2005). 
In addition, municipalities have the faculty to decide how to spend their money, since they approve the expenditure budgets of their own resources. However, the power to collect taxes or royalties has to be granted by the income laws approved by each state's congress every year.

Municipalities have the right to propose tax rates, as well as tax and royalty scales, and the State Congress decides whether to approve or reject these proposals. All charges must be enabled by law. ${ }^{16}$ Ultimately this is where the catalogue of databases of the fiscal Units, which we will discuss in this article, come from.

Before addressing the faculties granted by the Constitution, it is important to note that each state can regulate the way it implements its laws and public policies. Let us remember that federal models (Mexico, Brazil, Argentina and the United States) grant the states the possibility to adjust constitutional law, while respecting the frames it provides. ${ }^{17}$ Therefore, and in order to understand the behavior of each municipality, it will be necessary to examine their sub-national particularities. There are even some municipalities that yield some of the faculties that the Constitution confers upon them to the state to which they belong. ${ }^{18}$

According to the Constitution, municipalities will receive the contributions and any additional taxes on real state, their subdivision, division, consolidation, transfer and improvement, determined by the states, as well as those regulated by real estate value modifications, in accordance with article 115. Clearly, these faculties also include databases.

As can be observed, municipalities are mainly responsible for collecting land related taxes. In addition to the above, municipalities collect the rights and royalties for which they are constitutionally enabled. ${ }^{19}$

Article 115 fraction III of the Mexican Constitution establishes that municipalities also have the following faculties: 1) drinking water, 2) drainage, 3) sewerage, 4) waste water treatment and disposal, 5) public lighting, 6) waste

16 Constitutional Controversy 163/2016, Suprema Corte de Justicia de la Nación [S.C.J.N], [Supreme Court], 13 de febrero de 2018, (Mex.); Constitutional Controversy 14/2004, Suprema Corte de Justicia de la Nación [S.G.J.N], [Supreme Court], 22 de diciembre de 2004, (Mex.).

17 José María Serna, El Sistema Federal Mexicano (Porrúa, 2009); Pedro Torres, El modelo federal mexicano a la luz de los modelos comparados. La necesidad de la incorporación en la constitución de los principios de subsidiariedad y solidaridad como principios informadores y delimitadores del sistema de competencias, in Isotimia 2, 87,97 (Editorial Porrúa, 2009).

18 The company Servicios de Agua y Drenaje de Monterrey, which provides water and drainage services to the municipalities of the metropolitan area, functions as an example. In the international context, Barcelona's metropolitan area that comprises 36 municipalities was created in 2010. One of its faculties is to supply water. See, Law 31/2010 of Barcelona Metropolitan Area, Parliament of Catalonia, July 27, 2010.

19 The Federal Tax Code defines duties as the contributions established by law for the use or exploitation of the Nation's public domain assets and royalties corresponding to earnings resulting from public-law functions other than contributions, income derived from financing and those obtained by decentralized agencies. See, Código Fiscal de la Federación [G.F.F] [Federal Tax Code], as amended, Diario Oficial de la Federación [D.O.F], 31 de diciembre de 1981 (Mex.). 
cleaning, collection, transfer, processing and final disposal, 7) markets, 8) central distribution markets, 9) cemeteries, 10) slaughterhouses, 11) streets, and 12) parks, gardens, and public security; pursuant to article 21 of the Constitution (police and transit).

Besides the faculties already set forth, the local legislature of each state assigns other faculties to their municipalities, namely, states may expand the faculties of their municipalities derived from their residual faculties. ${ }^{20}$

In addition to the foregoing, in terms of the corresponding federal and state laws, article 115, fraction V, grants municipalities the following faculties: 1) to formulate, approve and administer the municipalities' urban development zoning and planning processes; 2) to participate in the creation and management of its territorial reserves; 3) to take part in the formulation of regional development plans; 4) authorize, control and monitor land use; 5) to get involved in urban land ownership regularization; 6) to grant construction licenses and permits; 7) to take part in the creation and management of ecological reserves and the development and implementation of their management programs; 8) to contribute in the formulation and implementation of public passenger transport programs, when they affect their territorial scope.

These are the faculties directly granted by the Mexican Constitution. However, some general laws also grant them other faculties not expressly stated in the Constitution, as is the case of the General Civil Protection Act. ${ }^{21}$ Nevertheless, for purposes of what we want to demonstrate, constitutional faculties suffice to evidence the general hypothesis of this article, which is that municipalities are strategic in the control of criminal assets and the creation of a national system to control criminal assets.

Further on, we will describe how a municipal government is organized in order to understand its structure and, based on its faculties, justify which municipal instance must be responsible for the ORPI alters resulting from its public policy, understand its basis and what is the main input required to develop an effective public policy to control assets in a federal model.

\section{Municipal Organization and Databases}

Municipalities are governed by a town hall chaired by the municipal president, who in turn works with a municipal secretary and treasurer. ${ }^{22}$ Further on, we

20 The residual principle applies in federal systems; that is to say, anything that is not expressly assigned to the federation belongs to the states.

21 Published on June 6, 2012 in the Official Journal of the Federation. An example of a municipal faculty in the field of civil protection is the one set forth in article 84, regarding the creation of a population's public and private patrimonial risks' atlas.

22 Municipalities are organically regulated in each state through their constitution and by an organic law issued by the state legislature, where the main functions of each municipal public servant are defined. 
will go over the names of some of the ministries that control information relevant for the public policy; however, different states and municipalities can have different names for these ministries or directorates, according to their local norms and standards. ${ }^{23}$

In accordance with its faculties and functions, the municipal treasury must be the area mainly responsible for issuing alerts and developing intelligence products since, as we have already analyzed, this area controls most of the municipality's information, through its municipal fiscal records. At the end of the day, most municipal proceedings are registered in the budgets and records, both for incomes and expenditures.

As previously stated, there is a wide range of municipalities with various sizes and institutional strengths. Urban municipalities may be able to develop intelligence products that alert other government agencies, ${ }^{24}$ since information is their basic input.

The political will of the municipal president is crucial for the existence and quality of its databases to become a public policy because, without this premise, the proposed public policy will suffer a structural weakness.

Furthermore, another issue that has to be addressed is the lack of political will in the municipalities' various areas regarding the creation, access and delivery of the updated databases to their treasuries. While all public policies risk colliding with bureaucracies that can derail or even make them fail, the political will of decision-makers will be vital to sustain them, in addition to imposing on, and convincing bureaucratic elites of implementing them, as well as punishing those who do not.

Information can tangibly expose some of the areas of opportunity of local governments. For example, it can identify that a certain unit has materially decreased its inspection or verification processes or its ability to collect fines. Economic registries will represent the main certainty for this policy.

Another issue is to establish that databases should be centralized in the treasury and, if this is not the case or if it is not possible to do so, then the treasury will need direct access to the databases of all the ministries that generate acts over which it must collect an income, in real time. ${ }^{25}$

In this sense, treasuries will register individuals' patrimonial and economic activities through payments made by taxpayers, derived from taxes, fees and royalties, to create a patrimonial profile of individuals and the main activities

23 It is important to say that the municipality of General Escobedo in the State of Nuevo Leon was chosen as sample because the field work for this research was carried out in the said community.

24 According to the INEGI, a community is considered to be rural when it has less than 2,500 inhabitants, while an urban community has more than 2,500 inhabitants. See, Población rural y urbana, INEGI (August 25, 2019), http://cuentame.inegi.org.mx/poblacion/rur_urb.aspx?tema=P.

25 Obviously, the technological element is very important, and we refer to the platform that concentrates the information. However, this cannot be a valid pretext for municipalities with a regular institutional capacity to stop generating and ordering their information. 
Esta revista forma parte del acervo de la Biblioteca Jurídica Virtual del Instituto de Investigaciones Jurídicas de la UNAM

developed in their community. Some of the payments registered by treasuries are listed in Table 1.

Table 1. Payments Registered by Municipal Treasuries

\begin{tabular}{|l|l|}
\hline \multicolumn{2}{|c|}{ Treasury } \\
\hline Municipal cadaster & Tax credits' installments' database \\
\hline Municipal taxpayers' registry & Tax verifications' database \\
\hline Municipal suppliers' database & Ad endorsements' database \\
\hline Alcohol endorsements' database & Parking exclusivities' database \\
\hline Fiscal fines and penalties & Vacant lots' registry \\
\hline
\end{tabular}

Source: Garcia, Sylvia Camila, with information obtained from interview with municipal authorities (Oct. 21, 2019). ${ }^{26}$

As may be observed, the treasury's databases have a vast potential to identify, among other things, who owns land within the municipal borders or who is buying real state in a given period of time and place. It will be possible to verify if the owner's tax domicile is in the municipality, and if the domicile is congruent with the value of the properties. For example, tax domiciles located in abandoned houses for high-value properties lead us to assume that this profile is not the final beneficiary.

In Mexico, many of the resources resulting from drug trafficking have been used to purchase ranches and country houses. We must remember that it is a more flexible activity in fiscal terms, and that it is easier to transfer cash in many of its activities. Land related information is also concentrated by municipal authorities. ${ }^{27}$

Of course, state authorities also have access to this information through the public registry of property. However, as it has already been mentioned, regarding local entities, it is easier to identify these activities in the field. In municipalities, it is easier to spot the purchase of large amounts of land, atypical transac-

26 Interview with municipal authorities in Nuevo Leon, Mexico (Oct. 21, 2019).

27 According to the Proceso magazine, in 2018, the prosecutor's office seized the ranch of former Governor Roberto Sandoval, accused of illicit enrichment. See, Fiscalia de Nayarit prepara aseguramiento de otro rancho de exgobernador Sandoval, Proceso (Mexico) (April 12, 2018), https:// wrerc.proceso.com.mx/529658/fiscalia-de-nayarit-prepara-aseguramiento-de-otro-rancho-del-exgobernadorsandoval. Likewise, the Attorney General of the State of Chihuahua seized 4 ranches belonging to the state's former governor Cesar Duarte, which exceeded 2 thousand hectares, after being accused of illicit enrichment. See, Asegura FGE otros 4 ranchos de Duarte; superan las 2 mil hectáreas de extensión, El Heraldo de Chinuahua (Mexico), 26 de febrero de 2018. Further, by the middle of 2019 the auctioning process of ranches, mansions and safe houses linked to drug trafficking started. The expectation was to obtain at least 368 million pesos. See, Diego Oré, México subasta ranchos, mansiones y casas de seguridad de narcos, Reuters, (June 23, 2019), https://lta.reuters.com/ar ticulo/mexico-narcos-subasta-idLTAKCN1TOORL-OUSLT. 
tions and investments in land, purchase of livestock (municipalities have the farmers' registry through the livestock registry), among others.

Another important piece of information may be who holds the updated alcohol endorsements; that is to say, who controls the alcohol's points of sale and how this trend has been configured. For example, review what brands concentrate the permits, who owns the bars, deposits or canteens, and which ones are the most problematic.

Fines resulting from alcohol illegal sales, or quarrels or scandals, are important information, for example, to renew permits or authorizations for those establishments. ${ }^{28}$ If there is no information available, the Authority's decisions will seem arbitrary.

As for the water service supply's databases, although in many municipalities this service is provided by decentralized bodies of the municipal administration, we cannot lose sight of the fact that it is a local faculty. In this regard, having the beneficiaries' information will help cross examine the information to verify commercial or residential properties.

Meanwhile, City Hall generates the following databases related to collections made by the municipal treasury, as listed in Table 2.

\section{Table 2. Databases Generated by Gity Hall}

\begin{tabular}{|l|}
\hline \multicolumn{1}{|c|}{ City Hall } \\
\hline Vacant lots' registry (together with the Finance Ministry) \\
\hline Businesses' going out of business \\
\hline Inspections, controls and supervision fines \\
\hline Fixed and semi-fixed business' census \\
\hline Street vendors' registry \\
\hline Street markets tenants' registry (tianguis) \\
\hline Municipal markets \\
\hline Civil protection \\
\hline Sanctions derived from the Public Entertainment Rules \\
\hline Approvals \\
\hline
\end{tabular}

Source: Garcia, Sylvia Camila, with information obtained from interview with municipal authorities (Oct. 21, 2019). ${ }^{29}$

Derived from its inspections, the municipality may also have information in reference to the commercial establishments that violate regulations. The Inspection Department can provide information resulting from its visits, espe-

28 In some states, municipalities issue the permits directly, while in others the approvals are granted by the municipalities, and the state issues the permits.

29 Interview with municipal authorities in Nuevo Leon, Mexico (Oct. 21, 2019). 
cially if it uses closed and open fields, with key words to verify information that is important for the municipality. For example, it can verify if the information provided by local taxpayers is real. In case of false information, an alert would be sent to the municipal analysis unit, which we will discuss further on.

The businesses' census, as well as the street vendors' and markets' registries can help identify individuals, trade unions or organizations that use this type of figures to generate "funnel accounts" used to introduce or remove money from the financial system. ${ }^{30}$ In some cases, licit and illicit money are combined and all this information can help identify possible tax discrepancies with field information, or even crimes.

Public entertainment permits or approvals can also provide interesting information; for example, dancing and rodeo permits and approvals for cockfights, horse racing and raffles, among others. While it is true that permits are issued by the Ministry of the Interior, the municipality must also give its consent. ${ }^{31}$ Also, the municipality is able to verify certain information through the Municipal Public Entertainment Rules; for example, if shows are a simulation to introduce illegal money into the financial system; ${ }^{32}$ hence the importance of municipal alerts. Although the financial system is not a municipal issue, it can provide information to either the Secretaria de Hacienda y Crédito Público (SHCP for its acronym in Spanish) Financial Intelligence Unit (henceforth FIU) or its counterparts in the states.

The Urban Development and Ecology Ministry, responsible for ordering the land within the municipality's borders, also controls very important information. The databases generated by this ministry are listed in Table 3.

\section{Table 3. Urban Development and Ecology}

\section{Ministry Databases}

\begin{tabular}{|l|}
\hline \multicolumn{1}{|c|}{ Urban Development and Ecology Ministry } \\
\hline Land use, building and construction permits' requests \\
\hline License applications for mergers, parcellations, subdivisions and re-parceling databases \\
\hline Urbanization works' database \\
\hline Urban projects' database \\
\hline Authorized street publicity \\
\hline Commercial and industrial services' regularization database \\
\hline Environmental sanctions' database \\
\hline
\end{tabular}

30 Funnel accounts are used to drop small amounts, so they do not stand out.

31 SEGOB, Requisitos para Peleas de Gallos, Gobierno de México, (Oct. 10, 2019), http:// wrew.juegosysorteos.gob.mx/es/fuegos_y_Sorteos/Peleas_de_gallos.

32 For example, the number of tickets paid in cash for public entertainment and dances can be simulated in order to introduce money into the financial system. 


\begin{tabular}{|l|}
\hline \multicolumn{1}{|c|}{ Urban Development and Ecology Ministry } \\
\hline Urban development inspection and proceedings' database \\
\hline Urban development sanctions' database \\
\hline Environmental protection sanctions' database \\
\hline Nomenclature Rules sanctions' database \\
\hline Road Access Rules sanctions' database \\
\hline
\end{tabular}

Source: Garcia, Sylvia Camila, with information obtained from interview with municipal authorities (Oct. 21, 2019). ${ }^{33}$

As previously mentioned, urban development areas are very important because they control the information of the areas where more money is invested in the municipalities, such as constructions, industrial developments, farms and commerce and housing, among others. In some cases, satellite photos of the constructions are used for cadastral modernization. ${ }^{34}$

To start with, it can be stated that, at least formally, land use information is available. The municipality can close down a work that doesn't have that required permits and that way it can develop an information registry of the individuals building inside its boundaries. This is one of the basic inputs required to understand the patrimonial activities of individuals or their final beneficiaries.

It is necessary to highlight land use, building and construction licenses' information and license requests for mergers, parceling, subdivisions and divisions into lots, as well as urban development inspections and proceedings. ${ }^{35}$ If each municipality had well-ordered and up-to-date databases, it would have quality raw material to control criminal assets.

Finally, the municipality has information on the pawnshops opened within its borders. It is important to know who they belong to or who is their legal representative. Although this information is not controlled by municipalities, it is public information filed in the Public Commerce Registry. ${ }^{36}$

Financial matters are controlled by federal courts and involve issues related to the financial system (banks, insurance companies, bonding companies

33 Interview with municipal authorities in Nuevo Leon, Mexico (Oct. 21, 2019).

34 Cadastral modernization refers to the municipality's updated construction atlas, to calculate property taxes.

35 It is important to say that the person or entity requesting the permit is not always the final beneficiary. Nevertheless, providing ownership evidence can help authorities and give information on the individuals or entities that request the permits.

36 The incorporation, transformation, merger, spin-off, dissolution and liquidation of a company can be reviewed in real time in the web site. This information is very important to know who are the individuals behind the companies. See, Registro Público de Comercio [R.P.C] [Public Registry of Commerce], 8 de agosto de 2018 (Mex.), https://rpc.economia.gob.mx/siger2/xhtml/ login/login.xhtml. 
and retirement funds' administrators (AFOREs), among others). ${ }^{37}$ Although there is a lot of money involved, a large part of it is also invested in real estate and it is the municipalities who control the most relevant information. We must also mention the states, which control vehicle database; where a large amount of the offenders' resources are spent. This article will only deal with municipal databases.

If a person is involved in a crime, besides proving his or her guilt before a judge, the money involved must be recovered to compensate the victims; ${ }^{38}$ it is also necessary to verify what other assets are the product of the criminal's illicit activities and seek for said assets to be transferred to the state's ownership.

In addition to their illegal origin, many of the criminal's assets are also used as tools to commit crimes. We believe that the best way to win this battle is, as in conventional wars throughout history, by gaining ground, taking away the opponent's weapons, its attack weapons (land, air and sea vehicles) being money provision logistics and supplies.

Without money, criminals cannot pay bribes or their employees' payroll; criminal organizations are paralyzed and their physical and economic mobility structures are eliminated. Therefore, it is important to promote that municipalities issue alerts. Additionally, municipal databases are an important source of information for prosecutors, who may rely on them to define the criminals' patrimonial profile, mainly in municipalities where it is presumed that they may own assets, so they can verify that they are not the proceeds of crime. Similarly, if the said assets are illegally obtained, this will make it easier to locate them in order to initiate legal proceedings and take away the offenders' rights on the said assets. ${ }^{39}$

Lastly, the Public Services Ministry also generates information such as the "public garbage service taxpayers' database". This database is important to

37 The Mexican banking system is integrated by the Bank of Mexico, commercial banks, development banks and public trusts incorporated by the Federal Government for economic development purposes, as well as banking self-regulating agencies. Refer to article 3 of the Credit Institutions Law. Likewise, the financial entities that make up the Mexican financial system are the following: a) financial groups holding and sub-holding companies, $b$ ) credit institutions, c) brokerage houses, d) stock exchanges, e) investment funds, f) fund operators, $g$ ) investment fund distribution companies, $h$ ) bonded warehouses, $i$ ) credit unions, exchange houses, $j$ ) multipurpose regulated financial companies, $k$ ) financial cooperative associations, $l$ ) securities depositary institutions, central counterparties, $m$ ) rating institutions, $n$ ) financial technology institutions, o) credit information societies, $p$ ) financial community partnerships under the supervision of the Commission and the rural financial integration entities, as well as other institutions, $q$ ) public trusts with financial activities supervised by the Commission; all of them incorporated under commercial and financial laws. In addition to the above, the savings and credit cooperatives make up the financial system. See, Ley de la Comisión Nacional Bancaria y de Valores [L.C.N.B.V] [National Banking and Securities Commission Law] (Mex.).

38 Under the Expired Ownership Act, the prosecutors' offices must issue a protocol for prosecutors to give notice when there is an ORPI related offence.

39 See, Ley Federal de Extinción de Dominio [L.F.E.D] [Federal Law of Extinction of Domain], Diario Oficial de la Federación [D.O.F]. 
understand how many people use this service and to verify the veracity of the information provided by citizens; for example, a property originally registered as a vacant lot, where there is actually is a shopping mall that hasn't been registered and that is receiving garbage collection services without paying the corresponding taxes.

It is important to say that the information that may be obtained and validated through the municipality can be used not only to locate money resulting from criminal activities, but also to detect local, state and federal tax evasion, as well as fiscal discrepancies and ORPIs.

In this article we're going to focus on financial information, but it is important to mention that public safety areas also generate information through their analysis areas, although it is usually criminal rather than financial or fiscal information. Next, we're going to talk about the area that should implement this public policy.

\section{Municipal Tax Information Analysis Areas}

Once the legal design has been developed and before the Unit begins to operate, it is important to integrate it into the municipal rules. As we know, for an authority to act it must be granted the required faculties within the regulatory framework.

Consequently, this new Unit has to be included in the organic rules of the municipality. The Unit would need to depend on the treasury since, as we have already discussed, the basic information to develop the intelligence products is generated there.

Also, another element that has to be defined in the rules is this new Unit's functions, which must at least include the following:

1) To define the guidelines to register the information regarding the activities for which the municipality collects money. That is to say, the Unit must establish the report formats, either in a centralized database or for each ministry. It would be advisable to have one centralized database.

2) To issue a report on the quality of the information regarding the information generated in the municipal databases, so decision-makers may be aware of the public policies institutional weaknesses or strengths, since the quality of the information is its basic input.

3) To generate products to identify how each municipality functions and behaves, i.e., how is it performing within its assigned faculties; for example, how many fines are being issued during each month, how many permits are being granted or how many taxes have been collected. This information will make it possible to identify the behavior of each municipal area and generate alerts on the ministries' atypical behaviors and their activity or lack of activity. 
4) To generate periodic reports on the municipality's strategic, tactical and operational risks. For example, a strategic risk would be land ownership concentrated by highly aggressive speculative companies; a tactical risk would be the opening of an atypical number of pawnshops and an operational risk would be to identify a crime leader or criminal family with economic and patrimonial interests in the municipality. In the following heading we will explore the products in more detail.

5) To identify the patrimonial activity of politically exposed individuals in the municipality ${ }^{40}$ or to generate the information requested by the prosecutor regarding specific objectives with economic or fiscal activity in the municipality.

In short, the Unit must analyze the fiscal and economic behavior of the municipal organization and generate alerts regarding economic and patrimonial risks that loom over the municipality.

\section{The Unit's Structure and Basic Products}

The organization of a Unit of this type has to include identifying the size of the municipal population, the number of the treasury's and other areas' annual transactions, as well as defining the products it wants to generate.

Its basic structure includes the following functions: one Unit manager, who will head it and be responsible for the products it generates. It must also include two areas able to deploy a number of analysts, according to the needs of the municipality.

One of these areas would be responsible for compiling and processing information, and the other would be responsible for analyzing it. The main function of the area responsible for collecting and processing information will be to gather all the information required to develop the expected products, so that the analysis area may access it.

For example, part of its faculties would be to define the formats required to register information, as well as to identify new databases, either municipal or belonging to other public and private entities, as well as to sign information exchange agreements. The more well-ordered information the Unit has, the faster and more powerful it will become.

The analysis area would use various scientific and empirical methods to analyze the information and generate the intelligence products required for decision-making, according to its public policy.

A Unit of this type must at least generate the following products:

1) To design a public policy to prevent ORPIs in the municipality. This product will determine where the municipality will focus its activity. That is to

40 Personas Políticamente Expuestas, [Politically Exposed People] Secretaría de Gobernación, 2 de octubre de 2019 (Mex.). 
say, the Unit has to stablish where it is going to concentrate its inputs and human resources to give preference to monitoring certain products over others, using its intelligence products to prevent ORPIs.

For example, touristic municipalities will need to be more attentive to investments made in hotels and bars; other municipalities with an industrial vocation will have to pay close attention to warehouses inside its territory. This product is the basis of the public policy for the analysis of tax municipal information and its purpose is to analyze and determine why it should focus its public policy on those activities rather than on others. An important criterion is to define the most relevant risks for the municipality and its inhabitants, at present and in the future.

2) To generate a report on the municipal databases and their quality. This is of the utmost importance since the existing raw material has to be evaluated systematically, "this is the clay to make bricks".

As already mentioned, it is very important for municipalities to be aware of how land ownership moves in order to be able to identify possible behaviors that may affect municipal life. This is why it is important to make reports on land concentration or atypical purchases and it may also help create alerts. The path and use of money help develop tangible scenarios and assumptions regarding what is happening and what may happen in the municipality.

It will be necessary to have a control panel to monitor the tax activities of the various municipal areas. For example, to supervise how the trend of the fines imposed throughout the year, derived from civil protection matters, is handled, or to identify the activity or lack of activity of a specific municipal area. ${ }^{41}$ It will also help monitor the decrease of its income and why the said income has decreased; for example, a large number of fines being imposed or the opposite, or a sharp drop on tax collection. This information sends an alert to try to identify why things are happening.

In the end, we must be clear that an alert is a warning call to focus on the required efforts to try to explain what is happening or what may happen, using scientific or empirical methods.

3) The Responsible Citizen Certificate, which certifies that citizens are not indebted to the municipality. In case a person has not paid a fine, he/she will not receive this certificate so he/she will not be able to process construction or land use permits. This can only be achieved if databases are well ordered and preferably concentrated in one single area. This increases the fulfilment rate of citizens' obligations before the municipality and provides greater governance to avoid impunity, through a more effective collection of administra-

41 The concept of civil protection encompasses the coherent set of actions designed to respond to the needs and demands raised by society, the imminence or culmination of a disaster that puts the lives, property and surroundings of its members at risk. See, Gonzalo Campos, Evolución legislativa de la protección civil en Mexico, in Protección Givil. RéGIMen Jurídico de Protecaión Givil en México 283, 301 (Laguna Publishing House, 2001). 
tive offenses. With some exceptions, nowadays municipalities have lost their authority due to the existing impunity in implementing sanctions. ${ }^{42}$

Another report that Units may be required to prepare in case their public policies require it is the one related to their patrimonial behavior of their public servants or politically exposed persons. In the case of public servants, the municipality will have information related to his/her assets' statement in order to identify any unexplained increase of the official's assets. As for politically exposed persons, at present they're not required to generate an alert before the FIU but, in case a possible crime is identified, they are obliged to report it to the local or federal prosecutor, as it may be the case. ${ }^{43}$

\section{Conclusion: Implementation and Consolidation Risks OF THESE NEw UNITS}

Every law or public policy has risks related to its implementation process. In this case, the main risks may include the following issues:

1) Lack of political will. If municipal presidents do not prioritize this public policy in their public agenda it will be difficult for it to work, since the Unit requires the information produced by all municipal areas. If the municipal president does not assume its leadership and supports the Unit, it will lack the basic input for it to function, namely information.

2) The temptation to use the Unit for purposes other than those it was designed for, such as for political purposes. This would mean its institutional death sentence and it would also represent a great risk, since it would be enough for the people being attacked to come into power for them to dismantle the Unit and start over.

Creating quality databases grants a lot of power, but it is a long and laborious process that is normally not achieved in one period of government. In this regard, we have observed that, in the federal order, when this type of phenomena has taken place, people in power chose to dismantle these institutions, as in the case of the Center for Investigation and National Security (CISEN for its acronym in Spanish). ${ }^{44}$

42 The report Perspectivas OECD: México Políticas Clave para un Desarrollo Sostenible notes that taxes represent the larger part of Mexican municipalities' income, but that their implementation is uneven. It also states that the local tax administration and administrative collection should be reinforced. See, Report Perspectivas OECD: México Políticas Clave para un Desarrollo Sostenible (October, 2010), https://wwweoed.org/Mexico/45391108.pdf.

43 Politically exposed individuals are included in the following list. The SHCP Financial Intelligence Unit issues it for financial agents to report their activities in the system. See, Personas Políticamente Expuestas (October 3, 2019), https://wrw.gob.mx/cms/uploads/attachment/ file/46540/Personas_Politicamente_Expuestas_Nacionales.pdf.

44 For a long time, this institution was used to weaken the government's political adversaries. It was reopened by the current left-wing government. 
3) The possibility that government changes substantially revoke or modify this public policy. If the Unit manages to consolidate a technical and independent profile, its institutional strength will increase. During its consolidation stage, we also consider it risky to submit it to a political corruption process, since political forces will control it with all their might. When greater strength and institutional consolidation are achieved, we do not see any risk in providing information in corruption cases.

During the first stage, it will be important to focus on the crimes that most affect the municipality, taking away from criminals that have broken the law all that they have obtained. For example, assets that result from human trafficking, kidnapping or drug dealing offences.

4) The possibility that the Unit is infiltrated by crime, meaning it could have information about money mobility in the region and who owns it. This can be a great challenge and demonstrates the need to take special care of the Unit, in identifying profiles and, above all, the person that heads it. It will be important for its members to have good salaries and professional careers to reduce the temptations of selling information.

5) That the Unit is unable to obtain information from all the municipal areas, or from other levels of government (federal, state and other municipalities), based on agreements.

The institutional legitimacy of the Unit will depend on the extent to which its products add value to decision making in other areas of the local government. If this does not occur, it will lose credibility and institutional strength. For the Unit to work it requires information and, if the areas do not provide it, they will obviously be betting on the failure of this public policy.

Not all municipalities in the country will be able to have a Unit that generates all the products of which we speak. However, in accordance with their institutional capacities, they will be able to create a Unit according to their local needs.

Regardless of the Unit, municipalities urgently need to develop databases that give them the possibility to make decisions based on evidence. The big problem of underdeveloped countries is that they do not have the required information to make decisions. ${ }^{45}$

45 Francis Fukuyama, La Construcción del Estado. Hacia un nuevo orden mundial EN EL SIGLO XX 20 (Ediciones B, 2004); Peter May, Claves para diseñar opciones de politicas, in ANtologías, Problemas Públicos y Agenda de Gobierno 235-256 (Miguel Ángel Porrúa, 2017). With regard to resources as a key part of the analysis and management of public policies, legal remedies are considered to be the regulatory backbone of the political-administrative program that structures their content such as the selection of other resources (organizational, procedural or financial). Information is another resource (cognitive resource), through which information provides the basis required for the decision-making phase. Other resources are the human, economic, relationships or interactive resources, as well as chronological, patrimonial and trusted resources, political support (majority resources) and strength (violence resource); the violence resource is used in dictatorial regimes and it is only used in democratic regimes under extreme duress. See, Joan Subirats, Análisis y Gestión de Políticas Públicas 71,94 (Ariel, 2012). 
Esta revista forma parte del acervo de la Biblioteca Jurídica Virtual del Instituto de Investigaciones Jurídicas de la UNAM

To strengthen the figure of the Municipal Information Analysis Unit, it is necessary to create regulations that establish its form of operation. In this way, its operation will be guaranteed in the short and long term.

The information that the Municipal Unit will analyze, due to its characteristics, will have to guarantee the protection of the personal data of taxpayers and their rights.

Therefore, the municipalities must design dissemination strategies about the objective of the analysis units, guaranteeing transparency in their operation.

VIII. ANNEXES

Annex 1. Metropolitan Areas Defined Based on Intermunicipal or Interstate Conurbations

\begin{tabular}{|c|c|c|}
\hline Metropolitan Area & State & $\begin{array}{c}\text { Total Number } \\
\text { of Municipalities }\end{array}$ \\
\hline National & National & 417 \\
\hline Aguascalientes & Aguascalientes & 3 \\
\hline La Laguna & $\begin{array}{c}\text { Coahuila de Zaragoza- } \\
\text { Durango }\end{array}$ & 5 \\
\hline Monclova-Frontera & Coahuila de Zaragoza & 4 \\
\hline Piedras Negras & Coahuila de Zaragoza & 2 \\
\hline Saltillo & Coahuila de Zaragoza & 3 \\
\hline Colima-Villa de Álvarez & Colima & 5 \\
\hline Tecomán & Colima & 2 \\
\hline Tuxtla Gutiérrez & Chiapas & 5 \\
\hline Valle de México & $\begin{array}{c}\text { Mexico City- } \\
\text { Hidalgo-Mexico }\end{array}$ & 76 \\
\hline Moroleón-Uriangato & Guanajuato & 2 \\
\hline San Francisco del Rincón & Guanajuato & 2 \\
\hline Pachuca & Hidalgo & 7 \\
\hline Tulancingo & Hidalgo & 3 \\
\hline Guadalajara & Jalisco & 10 \\
\hline Ocotlán & Jalisco & 3 \\
\hline Puerto Vallarta & Jalisco-Nayarit & 2 \\
\hline Tlanguistengo & Mexico & 6 \\
\hline Toluca & Mexico & 16 \\
\hline La Piedad-Pénjamo & $\begin{array}{c}\text { Guanajuato-Michoacán de } \\
\text { Ocampo }\end{array}$ & 2 \\
\hline Morelia & Michoacán de Ocampo & 3 \\
\hline
\end{tabular}


Esta revista forma parte del acervo de la Biblioteca Jurídica Virtual del Instituto de Investigaciones Jurídicas de la UNAM

\begin{tabular}{|c|c|c|}
\hline Metropolitan Area & State & $\begin{array}{c}\text { Total Number } \\
\text { of Municipalities }\end{array}$ \\
\hline Zamora & Michoacán de Ocampo & 2 \\
\hline Cuautla & Morelos & 6 \\
\hline Cuernavaca & Morelos & 8 \\
\hline Tepic & Nayarit & 2 \\
\hline Monterrey & Nuevo León & 18 \\
\hline Oaxaca & Oaxaca & 24 \\
\hline Tehuantepec & Oaxaca & 5 \\
\hline Puebla-Tlaxcala & Puebla-Tlaxcala & 39 \\
\hline Tehuacán & Puebla & 2 \\
\hline Teziutlán & Puebla & 2 \\
\hline Querétaro & Guanajuato-Querétaro & 5 \\
\hline Cancún & Quintana Roo & 2 \\
\hline Rioverde & San Luis Potosí & 2 \\
\hline San Luis Potosí & San Luis Potosí & 3 \\
\hline Villahermosa & Tabasco & 2 \\
\hline Tampico & $\begin{array}{c}\text { Tamaulipas-Veracruz de } \\
\text { Ignacio de la Llave }\end{array}$ & 5 \\
\hline Tlaxcala-Apizaco & Tlaxcala & 19 \\
\hline Acayucan & Veracruz & 3 \\
\hline Coatzacoalcos & Veracruz & 3 \\
\hline Córdoba & Veracruz & 4 \\
\hline Minatitlán & Veracruz & 6 \\
\hline Orizaba & Veracruz & 13 \\
\hline Poza Rica & Veracruz & 5 \\
\hline Veracruz & Veracruz & 6 \\
\hline Xalapa & Veracruz & 9 \\
\hline Mérida & Yucatán & 11 \\
\hline Zacatecas-Guadalupe & Zacatecas & 5 \\
\hline
\end{tabular}

Source: CONAPO, INEGI, SEDATU, SEGOB. Delimitación de las zonas metropolitanas DE MÉxico 2015 (2015).

Annex 2. Metropolitan Areas Based on Statistical and Geographical Griteria

\begin{tabular}{|c|c|c|}
\hline Metropolitan Area & State & $\begin{array}{c}\text { Total Number } \\
\text { of Municipalities }\end{array}$ \\
\hline Tijuana & Baja California & 3 \\
\hline Chihuahua & Chihuahua & 3 \\
\hline
\end{tabular}


Esta revista forma parte del acervo de la Biblioteca Jurídica Virtual del Instituto de Investigaciones Jurídicas de la UNAM

\begin{tabular}{|c|c|c|}
\hline Metropolitan Area & State & $\begin{array}{c}\text { Total Number } \\
\text { of Municipalities }\end{array}$ \\
\hline Delicias & Chihuahua & 2 \\
\hline Hidalgo del Parral & Chihuahua & 2 \\
\hline Celaya & Guanajuato & 2 \\
\hline Chilpancingo & Guerrero & 5 \\
\hline Tula & Hidalgo & 2 \\
\hline Guaymas & Sonora & 2 \\
\hline Reynosa & Tamaulipas & 2 \\
\hline
\end{tabular}

Source: CONAPO, INEGI, SEDATU, SEGOB. Delimitación de las zonas metropolitanas DE MÉxico 2015 (2015).

\section{Annex 3. Metropolitan Areas Defined by Size and Because They Are State Capitals}

\begin{tabular}{|c|c|c|}
\hline Metropolitan Area & State & $\begin{array}{c}\text { Total Number } \\
\text { of Municipalities }\end{array}$ \\
\hline Juárez & Chihuahua & 1 \\
\hline Durango & Durango & 2 \\
\hline León & Guanajuato & 2 \\
\hline Acapulco & Guerrero & 1 \\
\hline Culiacán & Sinaloa & 1 \\
\hline Hermosillo & Sonora & 1 \\
\hline La Paz & Baja California Sur & 1 \\
\hline Campeche & Campeche & 1 \\
\hline Guanajuato & Guanajuato & 1 \\
\hline Chetumal & Quintana Roo & 1 \\
\hline Ciudad Victoria & Tamaulipas & 1 \\
\hline
\end{tabular}

Source: CONAPO, INEGI, SEDATU, SEGOB. Delimitación de las ZONAS MEtropolitanas DE MÉxico 2015 (2015).

\section{Annex 4. Metropolitan Areas Based ON THEIR SEA AND LAND BORDERS}

\begin{tabular}{|c|c|c|}
\hline Metropolitan Area & State & $\begin{array}{c}\text { Total Number } \\
\text { of Municipalities }\end{array}$ \\
\hline Mexicali & Baja California & 1 \\
\hline Tapachula & Chiapas & 1 \\
\hline Nogales & Sonora & 1 \\
\hline Matamoros & Tamaulipas & 1 \\
\hline
\end{tabular}


Esta revista forma parte del acervo de la Biblioteca Jurídica Virtual del Instituto de Investigaciones Jurídicas de la UNAM

MUNICIPALITIES AS PART OF THE SYSTEM TO CONTROL CRIMINAL...

\begin{tabular}{|c|c|c|}
\hline Metropolitan Area & State & $\begin{array}{c}\text { Total Number } \\
\text { of Municipalities }\end{array}$ \\
\hline Nuevo Laredo & Tamaulipas & 1 \\
\hline Ensenada & Baja California & 1 \\
\hline Mazatlán & Sinaloa & 1 \\
\hline
\end{tabular}

Source: CONAPO, INEGI, SEDATU, SEGOB. DeLimitación de LAS ZONAS METROPOlitANAS DE MÉXICo 2015 (2015).

Annex 5. Criteria to Define Metropolitan Areas

\begin{tabular}{|l|c|}
\hline \multicolumn{1}{|c|}{ Criteria } & \# Metropolitan Areas \\
\hline $\begin{array}{l}\text { Based on an interstate or intermunicipal } \\
\text { conurbation }\end{array}$ & 47 \\
\hline Statistical and geographic & 9 \\
\hline $\begin{array}{l}\text { Due to their size and because they are } \\
\text { state capitals }\end{array}$ & 11 \\
\hline Coast and land borders & 7 \\
\hline
\end{tabular}

Source: CONAPO, INEGI, SEDATU, SEGOB. Delimitación de las zonas metropolitanas DE MÉXIco 2015 (2015). 


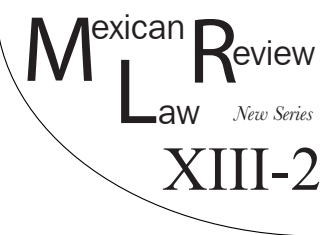

\title{
PERMANENT ECONOMIC EMERGENGY IN ARGENTINA AND ITS CONSTITUTIONAL IMPLICATIONS
}

\author{
Juan Santiago YLARRI*
}

\begin{abstract}
There is broad consensus among legal scholars about the existence of a permanent economic emergency in Argentina. This article examines the origin of the doctrine of economic emergency and its evolution in the Argentine Supreme Court of Fustice decisions. Various regulatory devices implemented to face the economic crises are analyzed, and it is emphasized that the declaration of a state of emergency has not been made only by means of Congress formal legislation, but through the legislative powers of the President. The requirements for the validity of regulations of emergency are set forth in this article, including the actual existence of a state of emergency, a public interest, that the measure be reasonable, and the provisional nature of the emergency. Considering that courts have not exerted proper judicial review over the regulations of emergency, guidelines to implement adequate judicial review over the subject at issue are presented. It is stated that the declaration of economic emergency and the factual circumstances underlying such declaration is a question subject to judicial review. In exercising the judicial review about this issue, two dimensions may be considered. First, timing, and, second, the correlation that must exist between a regulation - lawe, legislative delegation, or a decree of necessity and urgency - and the emergency situation it is intended to fight against. Finally, specific features of judicial review depending on the type of regulation that has declared the emergency are studied.
\end{abstract}

KEYWORDS: Economic emergency, declaration of economic emergency, legislative powers of the president, political question doctrine, judicial review.

RESUMEN: La doctrina coincide en la existencia de una emergencia económica permanente en la Argentina. En este artículo, se estudia el nacimiento de la

* Ph.D. in Law (Universidad de Buenos Aires). Master's in Constitutional Law (Centro de Estudios Políticos y Constitucionales, Spain). Researcher at Institute for Legal and Social Research "Ambrosio L. Gioja" (Universidad de Buenos Aires). Author of the book La emergencia económica. El control de constitucionalidad de la situación de emergencia económica y su declaración normativa (2019), and the book Los decretos-leyes y el control de la "extraordinaria y urgente necesidad"(2019). Email: juan@ylarri.com.ar. The author wishes to thank Mariano Vitetta and Nazareth Imperiale. Special thanks are also due to the editors of the Mexican Law Review for acute comments and for their editing suggestions. 
Esta revista forma parte del acervo de la Biblioteca Jurídica Virtual del Instituto de Investigaciones Jurídicas de la UNAM

doctrina de la emergencia económica y su evolución en la jurisprudencia de la Corte Suprema argentina. Se analizan los diversos mecanismos normativos para hacer frente a las crisis económicas, y se pone de relieve que la declaración de emergencia no ha sido efectuada únicamente por ley formal del Congreso, sino a través de las facultades legislativas del Presidente. Se exponen los requisitos para la validez de las normas de emergencia, incluyendo la efectiva existencia de una situación de emergencia, el interés público, que la medida sea razonable y que sea transitoria. Teniendo en cuenta que los tribunales no han ejercido un adecuado control de constitucionalidad sobre las normas de emergencia, se proponen pautas para un adecuado control judicial sobre el tema bajo estudio. Se afirma que la declaración de emergencia económica y las circunstancias fácticas que le sirven de base son una cuestión sujeta a revisión judicial. Al ejercer la revisión judicial sobre este tema, se pueden considerar dos dimensiones. Por un lado, el tiempo y, por el otro, la correlación que debe existir entre una norma - la ley, la delegación legislativa o un decreto de necesidad y urgencia-y la situación de emergencia que se pretende paliar. Finalmente, se estudian las características especificas de la revisión judicial en función del tipo de norma que ha declarado la emergencia.

Palabras Clave: Emergencia económica, declaración de emergencia, facultades legislativas del presidente, cuestiones políticas, control de constitucionalidad.

\section{Table of Contents}

I. INTRODUCTION

II. The Doctrine of Economic Emergency in Argentina................ 89

III. Normative Mechanisms to Declare Economic Emergency........... 95

IV. Consequences of Economic Emergency and Permanent ECONOMIC EMERGENCY

V. Judicial Review of Economic Emergency.....

1. Specific Features of Judicial Review Depending on the Type of Regulation that Has Declared the Emergency....

2. Two Dimensions in Exercising Judicial Review over Situations of Economic Emergency

3. Judicial Review of the Existence of an Actual Situation of Economic Emergency

4. Reasonableness

\section{INTRODUCTION}

Scholars agree that in Argentina there has been a permanent economic emergency for virtually one century. In 1922, the Argentine Supreme Court in the 
Ercolano case recognized broad police power and, in particular, emergency police power. Since then, branches of government have issued many economic and social emergency regulations. Resorting to the doctrine of emergency, far from being exceptional, has virtually become the regulation. The importance of the danger entailed by this endemic situation lies in that economic emergency regulations, as any other exceptional concept, have two key elements: on the one hand, they allow for the restriction of individual rights, especially economic liberties; on the other hand, they increase the powers of one of the branches of government, namely, the Executive. This is why the use of emergency powers must be subject to clear and specific requirements to be valid, and these requirements must be met by the bodies with the authority to declare the emergency. But reality shows that these requirements have not been met in constitutional practice and, at the same time, courts have been excessively deferential to the measures adopted by the branches of government.

My purpose in this article is to study the birth of the doctrine of economic emergency in Argentina and its evolution in the cases decided by the Argentine Supreme Court. Unlike the state of siege, which had been included in the original version of the Argentine Constitution, the concept of economic emergency has had no constitutional regulation, and its contents have been outlined by the decisions of the Argentine Supreme Court. I also elaborate on the multiple regulatory mechanisms to tackle economic crises. The declaration of economic emergency is the faculty of the Argentine Congress, in principle. Throughout decades, the Executive has been adopting a more important role, so declarations of emergency were made via the legislative powers of the president - in particular, legislative delegation and decrees of "necessity and urgency"- - In addition, I will pay special attention to the requirements for economic emergency regulations to be valid, including the actual existence of a state of emergency, a public interest, that the measure be reasonable, and the provisional nature of the emergency. While these requirements have been outlined by the Argentine Supreme Court very early in time, the truth is that no appropriate judicial review over economic emergency regulations has been exercised. Because of this, I will propose some guidelines for an effective judicial review of this topic and, ultimately, to put an end to the endless emergency.

\section{The Doctrine of Egonomic Emergency in Argentina}

Constitutional law draws a dividing line between normal situations and exceptional situations. Constitutions establish a set of mechanisms regulating certain situations which are considered to be normal and foreseeable. But there are certain extraordinary situations for which standard constitutional resources may not be sufficient. In fact, the Constitution establishes a given project in connection with a normal and foreseeable situation, but it may suddenly be confronted with a different situation, which had not been foreseen, 
so it may be faced with the impossibility of ensuring its own effectiveness. As a response to this crisis situation, many constitutions incorporate an alternative way of organizing power which entails the provisional denial of the original constitutional order. ${ }^{1}$ Therefore, in the exceptional scenarios when the general regulation established in the constitution cannot be applied, exceptional measures need to be adopted. But to apply these measures the new situation must really be rare and, thus, be limited in time. ${ }^{2}$

The Argentine Constitution has not been alien to these issues, so exceptional mechanisms have been included in it to tackle exceptional situations, outside the normal periods which the Constitution is intended to govern in a usual and permanent manner. While the gamut of emergencies is extremely varied, three categories may be identified: ${ }^{3}$ war, domestic disorder, and economic crisis. Up to the constitutional reform of 1994, the Argentine Constitution had regulated only one exceptional mechanism - the state of siege - Section $23^{4}$ establishes this mechanism in the event of war (actually, "foreign attack"), and "domestic disorder".

On the contrary, unlike the state of siege, economic emergency in the beginning had no place in the formal Constitution, but it was part of customary constitutional law, which produced a series of regulations - mainly court-made in nature - in connection with the conditions and limits of the emergency law stated in the laws and decrees that had declared and applied it. ${ }^{5}$ After the 1994 constitutional reform, two additional types of exceptional mechanisms were admitted: legislative delegation and decrees of necessity and urgency, ${ }^{6}$ both of which include economic emergency. Section $76^{7}$ of the Argentine Constitution refers to "public emergency" to admit, under exceptional circumstances,

1 See Pedro Cruz Villalón, Estados excepcionales y suspensión de garantías 18 (1984).

2 See Manuel García Pelayo, Derecho Constitucional Comparado 162-63 (1999).

3 See German J. Bidart Campos, Tratado Elemental de Derecho Constitucional ArGENTINO 301 (1995).

4 Section 23 Gonstitución Nacional [Const. Nac.]: "In the event of domestic disorder or foreign attack endangering the full enforcement of this Constitution and of the authorities hereby established, any province or territory which is in turmoil shall be declared in state of siege and the constitutional guarantees shall be suspended therein. But during such a suspension the President of the Republic shall not pronounce judgment or apply penalties on his or her own. In that case, his or her power shall be limited, with respect to persons, to their arrest or transfer from one place of the Nation to another, should they not prefer to leave the Argentine territory".

5 See Néstor P. Sagúés, La Constitución bajo tensión 70 (2016).

6 See, e.g., María Angélica Gelli, Constitución de la Nación argentina. Comentada y CONCORDADA 309 (2008); Alberto R. Dalla Vía, La doctrina constitucional de la emergencia, in ColECCión de Análisis Jurisprudencial Derecho Constitucional, 757, 760 (Alberto R. Dalla Vía, dir., 2002).

7 Section 76 Const. NAC.: "Legislative powers shall not be delegated to the Executive save for issues concerning administration and public emergency, with a specified term for their exercise and according to the delegating conditions established by Congress. The expiration of the 
the legislative delegation to the Executive "with a specified term for their exercise and according to the delegating conditions established by Congress", and Section $99(3)^{8}$ sets forth that the Executive may issue decrees on grounds of necessity and urgency only "when due to exceptional circumstances the ordinary procedures provided for under this Constitution for the enactment of laws are impossible to be followed, and when regulations do not involve criminal issues, taxation, electoral matters, or the system of political parties".

Authors have established a similarity between the state of siege and economic emergency, because just like the political state of siege, established under Section 23 of the Constitution, strongly limits rights with personal content, economic emergency entails an "economic state of siege", given that the regulations declaring the economic emergency strongly restrict rights with economic content. ${ }^{9}$

After having mentioned the constitutional regulations which are the basis for economic emergency nowadays, now I want to elaborate on the origins of this mechanism in Argentina. Emergency in the economic and social arena has been connected from the beginning with the concept of police power, which was born in American law, ${ }^{10}$ and it has been alleged that it is "famously broad and equally famously vague". ${ }^{11}$ While the Argentine Constitution, like the American Constitution, has no specific provision regarding police power, the existence of a police power has been asserted since the inception of constitutionalism, both by courts and by scholars. But it must also be noted that there are constitutional provisions which are the regula-

term established in the previous paragraph shall not imply the revision of the legal relationships emerging from the regulations issued as a result of the powers delegated by Congress".

8 Section 99(3) Const. NAc.: "The Executive shall never issue provisions of legislative nature; in the event any such provisions are issued by the Executive, they shall be absolutely and irreparably null and void.

Only when due to exceptional circumstances the ordinary procedures under this Constitution for the enactment of laws are impossible to be followed, and when regulations are not about criminal issues, taxation, electoral matters, or the system of political parties, the president may issue decrees on grounds of necessity and urgency, which shall be decided by a general agreement of ministers who shall countersign them together with the Chief of the Ministerial Cabinet.

Within the term of ten days, the Chief of the Ministerial Cabinet shall personally submit the decision to the consideration of the Permanent Bicameral Committee of Congress, which shall be composed according to the proportion of the political representation of the parties in each House. Within the term of ten days, this committee shall submit its report to the plenary meeting of each House for its specific consideration and it shall be immediately discussed by both Houses. A special law enacted with the absolute majority of all the members of each House shall regulate the procedure and scope of Congress participation".

9 See Alberto B. Bianchi, La Corte Suprema ha establecido su tesis oficial sobre la emergencia económica, 1991-C La LEY 141, 150 (1991).

10 See Alberto R. Dalla Vía, Derecho constitucional económico 437 (2006).

11 See Bernadette A. Meyler, Economic Emergency and the Rule of Law, 56 DePaul L. Rev. 539, 549 (2007). 
tory basis for the police power, such as Sections $14^{12}$ and $28,{ }^{13}$ mentioning the restriction of rights and guarantees. ${ }^{14}$ Police power is generally defined as the prerogative that the Government has to regulate or limit the exercise of individual rights to ensure certain purposes, with the resulting effect of limiting individual rights to make such concrete purposes effective. There is a narrow conception of the police power, including safety, public health, or morality, ${ }^{15}$ and a broad and plenary conception, conceived in the United States, adding well-being. ${ }^{16}$ The emergency police power is contained in the second conception.

In connection with the recognition of the exercise of the broad police power, the Argentine Supreme Court has closely followed the American Supreme Court, and there even are authors who have propounded that the Argentine Supreme Court has seen the American Supreme Court as an authority. ${ }^{17}$ Scholars have stated that Argentina has experienced the same change in court opinions as the one that has taken place in the United States. At the outset, the model chosen entailed a broad protection of private property and contractual relationships - the Lochner ${ }^{18}$ case is an example-. Afterwards, the depression of the 1930s forced the adoption of emergency measures, so the age of non-interventionism started to decline rapidly with the judgments in the Home Building and Loan Association v. Blaisdell, ${ }^{19}$ Nebbia v. New York, ${ }^{20}$ and West Coast Hotel v. Parrish $^{21}$ cases. $^{22}$

12 Section 14 Const. NAC.: "All the inhabitants of the Nation are entitled to the following rights, in accordance with the laws that regulate their exercise...".

13 Section 28 Const. NAC.: "The principles, guarantees, and rights recognized in the preceding sections shall not be modified by the laws that regulate their enforcement".

14 See Santiago Legarre, Poder de policía y moralidad pública 234 (2004).

15 Corte Suprema de Justicia de la Nación [CSJN] [National Supreme Court of Justice], 13/4/1869, “La Empresa 'Plaza de Toros', quejándose por un decreto expedido por el Gobierno de Buenos Aires", Colección Oficial de Fallos de la Corte Suprema de Justicia de la Nación [Fallos] (1869-7-150); 14/5/1887, "Los Saladeristas Podestá, Bertram, Anderson, Ferrer y otros contra la provincia de Buenos Aires; sobre indemnización de daños y perjuicios", Fallos (1887-31-273).

16 See, e.g., German J. Bidart Campos, Manual de la Constitución Reformada 344 (2000); Antonio M. Hernández, Las emergencias y la afectación del orden constitucional y de los derechos, in Derecho constitucional 319, 358 (Universidad ed., 2004).

17 See, e.g., Carlos Rosenkrantz, Against Borrowings and other Nonauthoritative Uses of Foreing Law, 1 InT'L J. Const L. 269, 275-76 (2003); José S. Elias, The Constitutional Protection of Property Rights in Argentina: A Reappraisal of the Doctrine of Economic Emergency, Yale LaW School Dissertations 5,138 (2014).

18 Lochner v. New York, 198 U.S. 45 (1905).

19 Home Building and Loan Association v. Blaisdell, 290 U.S. 398 (1934).

20 Nebbia v. New York, 291 U.S. 502 (1934).

21 West Coast Hotel v. Parrish, 300 U.S. 379 (1937).

22 See, e.g., Alberto B. Bianchi, Apunte preliminar para el estudio de la historia del Derecho Constitucional, 183 El Derecho 1053-65 (1999); Alberto B. Bianchi, Historia constitucional de los 
Similarly, in Argentina at a first stage there was a "liberal" conception, favoring the effective validity of the law to the detriment of the lawmaker's regulation powers; the landmark case is Hileret..$^{23}$ At the second stage, this interpretation changed, with the idea that certain regulations, which were more or less intense, of economic rights were not inconsistent with the Constitution. This stage begins with Ercolano, ${ }^{24}$ in which a regulation limiting the prices for urban leases was validated. The trend was consolidated in Avico, ${ }^{25}$ affirming an extension in mortgage payment terms. Finally, the trend became established, first, in Cine Callao, ${ }^{26}$ admitting a law requiring owners of cinemas to include live performances, and then in Peralta, ${ }^{27}$ in which a decree limited the repayment of term deposits, paying the remainder with public debt bonds. Because of the deep economic crisis in Argentina by the end of 2001, the Argentine Supreme Court handed down decisions like Smith, ${ }^{28}$ San Luis, ${ }^{29}$ and Tobar ${ }^{30}$ which could have led to think that there was going to be a change in the case law which broadly admitted limitations to economic liberties. In the end, the Argentine Supreme Court ratified the measures to tackle the 2001 crisis in Bustos ${ }^{31}$ and Massa, ${ }^{32}$ so it can be said that the Court continued with the line of broad deference to economic regulations.

The Argentine Supreme Court clearly referred to the emergency police power in Russo, ${ }^{33}$ where it repeated its prior doctrine on this matter. ${ }^{34} \mathrm{In}$ that case, the Court clarified that it had abandoned the restrictive doctrine ad-

Estados Unidos (2013); Juan Cianciardo, Derecho constitucional de emergencia y justicia. Interpretación por analogía, LA Ley, January 28, 2005, at 1-4; Juan Cianciardo, Los límites del sistema normativo (Consideraciones a propósito de la analogía, la justicia distributiva y el derecho de propiedad), LA LEY, August 10, 2004, at 2-8.

23 CSJN, 5/9/1903, "Hileret y otro c/ Provincia de Tucumán”, Fallos (1903-98-20).

24 CSJN, 28/4/1922, "Ercolano, Agustín c/ Lantieri de Renshaw, Julieta s/ consignación”, Fallos (1922-136-161).

25 CSJN, 7/12/1934, "Avico, Oscar Agustín c/ de la Pesa, Saúl G.”, Fallos (1934-172-21).

26 CSJN, 22/6/1960, "Cine Callao”, Fallos (1960-247-121).

27 C.SJN, 27/12/1990, "Peralta, Luis A. y otro c/ Estado Nacional (Ministerio de EconomíaB.C.R.A)", Fallos (1990-313-1513).

28 CSJN, 1/2/2002, "Banco de Galicia y Buenos Aires s/ solicita intervención urgente en autos: Smith, Carlos Antonio c/ Poder Ejecutivo Nacional o Estado Nacional s/ sumarísimo", Fallos (2002-325-28).

29 CSJN, 5/3/2003, "Provincia de San Luis c/ Estado Nacional s/ acción de amparo", Fallos (2003-326-417).

30 CSJN, 22/8/2002, "Tobar Leónidas c/ E.N. M Defensa - Contaduría General del Ejercito - Ley 25.453 s/ amparo - Ley 16.986”, Fallos (2002-325-2059).

31 CSJN, 26/10/2004, "Bustos, Alberto Roque y otros c/ Estado Nacional y otros", Fallos (2004-327-4495).

32 CSJN, 27/12/2006, "Massa, Juan Agustín c/ Poder Ejecutivo Nacional", Fallos (2006329-5913).

33 CSJN, 15/5/1959, "Russo, Angel y otra c/ C. de Delle Donne E.", Fallos (1959-243-467).

34 CSJN, 27 /12/1944, "Vicente Martini e Hijos, S.R.L Infac. Ley 12.591", Fallos (1944200-450); 21/6/1957, “Juan Domingo Perón”, Fallos (1957-238-76). 
opted in old decisions, and that it came to embrace a broad and full notion of the police power, one of whose elements is emergency. The Court established that an emergency situation is a factual requirement, i.e. the existence of crisis or serious social turmoil, and that given the need to face the damage or risks created as a result of this emergency situation and to erase or mitigate its effects, the regulatory power of the Congress is broader and deeper and entails that the Government is more involved in regulating rights. The Court said that in those cases there is an intensification of government power and that mechanisms or procedures which would otherwise not be valid are actually valid. "It is not that the emergency gives rise to a new power - it simply authorizes the exercise of an already existing power with more energy. Extraordinary events... require extraordinary remedies".

Some authors have highlighted that the doctrine of emergency ceased to be justified in the exercise of the emergency police power, and the matter was to be analyzed in light of the state of necessity, ${ }^{35}$ as some started to make express reference to the fact that the steps taken were necessary to ensure the "continuity and survival" of national union. ${ }^{36}$ Sagüés has made a very accurate analysis of this issue and has clearly stated that emergency law is a chapter of the necessity law, albeit subject to different requirements. ${ }^{37}$

Later on, the doctrine of economic emergency has been clearly explained by the Argentine Supreme Court in Risolía de Ocampo: ${ }^{38}$

When a situation of crisis or public necessity requires the adoption of measures to protect general interests, it is possible, without violating or eliminating any guarantees protecting economic rights, to delay, within reasonable limits, the performance of obligations stemming from acquired rights. It is not about recognizing degrees of omnipotence to the lawmaker or excluding the lawmaker from judicial review, but about not depriving the Government from any government measures deemed to be useful to bring relief to the community. Therefore, if a regulation is passed based on necessity reasons which does not deprive individuals from the economic benefits legitimately recognized or does not ignore the individuals' ownership over such benefits, but only provisionally limits the receipt of the benefits or restricts their use, there is no violation of Section 17 of the Constitution. This would just amount to a limitation imposed based on the need to mitigate or overcome a crisis situation. The Argentine constitutional system does not have any absolute rights and all rights are subordinated to the laws regulating the exercise thereof.

While the decisions of the Argentine Supreme Court have admitted the restriction of rights with economic content based on the doctrine of economic

\footnotetext{
35 See Dalla Vía, supra note 10, at. 443.

36 Peralta, Fallos (1990-313-1513).

37 SAGǗs, supra note 5, at. 94.

38 CSJN, 2/8/2000, "Risolía de Ocampo, María José c/ Rojas, Julio César y otros s/ ejecución de sentencia (incidente)", Fallos (2000-323-1934).
} 
emergency, the truth is that it has established certain requirements for the validity of the regulations entailing any such restriction. The different requirements ensuring that exercising the power of emergency is valid were systematically discussed by the Supreme Court in 1934, in the Avico ${ }^{39}$ case, which drew on the American precedent Home Building and Loan Association v. Blaisdell. ${ }^{40}$ While these requirements have been thought for a specific case, there can be no doubt that they are useful as a guiding standard for other decisions. ${ }^{41}$ These requirements are: (1) that there be an emergency requiring the exercise of exceptional powers to protect the key interests of the society; (2) that the law be aimed at satisfying a legitimate interest and not to benefit a particular group of individuals; (3) that the remedy applied be proportionate and justified in light of the emergency; (4) that the term under the law be reasonable and do not harm any of the parties; and (5) that the law be valid for a provisional period, limited to the emergency which caused it. While these guidelines are clear to outline the contour of the constitutionality of an emergency measure, the courts have admitted the validity of many regulations which did not comply with the requirements mentioned at all.

\section{Normative Mechanisms to Declare ECONOMIC EMERGENCY}

There are different types of legal regulations which may be used to establish more intense limits to the exercise of rights based on the existence of economic emergency. In principle, the Congress is the branch of government which has the power to declare the situation of economic emergency. Under Section 76 of the Constitution, the Congress also has the power to delegate to the Executive any powers required to put an end to economic emergency. In the event there is economic emergency and the requirements for necessity and urgency are met, the Executive may use the power under Section 99(3) of the Constitution and issue a decree of necessity and urgency. ${ }^{42}$

At the beginning, the Supreme Court accepted the stricter regulation of personal rights, especially property rights and the right to enter into contracts, and the Congress passed laws regulating those matters in the exercise of the police power. The Congress passed these laws based on the current wording of Section 75(18), ${ }^{43}$ the so-called "progress clause" and Section 14, stating

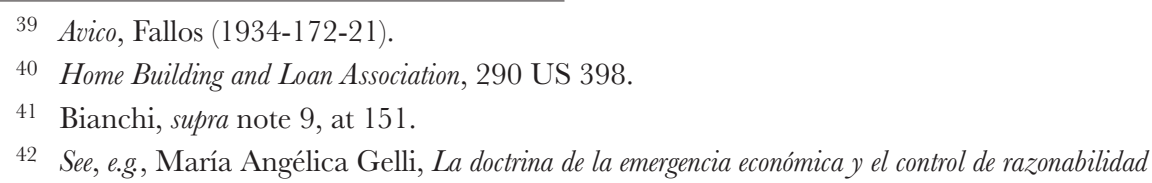
en el sistema constitucional argentino, in EMERGENCIA PÚBLICA Y REFORMA AL RÉGIMEN MONETARIO 25, 33 (Ricardo L. Lorenzetti, dir., 2002); Domingo J. Sesin, Administración Pública: actividad REGLADA, DISCRECIONAL Y TÉCNICA: NUEVOS MECANISMOS DE CONTROL JUDICIAL 321-22 (2004).

43 Under Section 75(18) Const. NAC. the Congress is empowered: "To provide for the prosperity of the country, for the progress and welfare of all the provinces, and for the advancement 
that rights are exercised in consistency with the laws regulating their exercise. In connection with the interpretation of the first of the precepts mentioned, it has been said the Supreme Court transitioned from admitting an increasing intervention of the Government on economic and social matters, based on the need to secure the general welfare and progress, to validate the remedies designed by the Legislature to solve any sectorial or general crisis. ${ }^{44}$

In many decisions, the Argentine Supreme Court affirmed the constitutionality of multiple regulations passed in exercise of the emergency police power, such as the regulation of urban lease prices, ${ }^{45}$ the extension of mortgage payment terms and the reduction of interest rates,${ }^{46}$ the stay of evictions, ${ }^{47}$ maximum prices in first-need products and goods, ${ }^{48}$ and the obligation to hire certain persons due to unemployment in a given industry, ${ }^{49}$ among many others.

There are two other normative instruments to tackle economic emergency, i.e. the legislative powers of the president: legislative delegation and decrees of necessity and urgency. As both normative devices had been used frequently, even if they were not expressly included in the Constitution, the constitutional reform incorporated them with the purpose of limiting them. Actually, during the constitutional debates in 1994, it was highlighted that one of the purposes of the reform was to generate a new balance in the operation of the three classic branches of Government - the Executive, the Legislature, and the Judiciary - and, therefore, to mitigate the presidential system, to strengthen the role of the Congress, and to attain more independence for the Judiciary. On that issue, the Supreme Court has noted that with firm and explicit wording the Argentine Constitution imposes a limitation on the president as a general regulation to pass provisions which are legislative in nature, whether on the president's own motion (Section 99[3]) or by virtue of a delegation made by the Congress (Section 76). Both sections, after establishing the principle, also state the conditions or limits under which the president is exceptionally empowered to exercise legislative functions. The wording of the constitutional text (Sections 99[3] and 76) unambiguously reflects the decision taken by the 1994 Constitutional Convention of, on the one hand, maintaining the general principle against the exercise of legislative powers by the president as a stan-

of education, drawing up general and university educational plans, and promoting industry, immigration, the construction of railways and navigable canals, the colonization of government-owned lands, the introduction and establishment of new industries, the imports of foreign capital, and the exploration of inland rivers, through laws protecting these aims and through temporary grants of privileges and stimulating rewards".

44 Gelli, supra note 42 , at 35.

45 Ercolano, Fallos (1922-136-161).

46 Avico, Fallos (1934-172-21).

47 CSJN, 15/5/1959, "Nadur, Amar c/ Borelli Francisco”, Fallos (1959-243-449); Russo, Fallos (1959-243-467).

48 Vicente Martini, Fallos (1944-200-450).

49 Cine Callao, Fallos (1960-247-121). 
dard practice and, on the other hand, to introduce more details about the exceptional conditions under which that may take place. The definition of the general regulation and the exceptional cases in the same constitutional text, as well as the procedure ultimately adopted to ensure the proper operation of both, is the correlation of two basic purposes of the constitutional deliberation: the mitigation of presidentialism and the more effective operation of the federal government. ${ }^{50}$

As explained, while legislative delegation had not been included in the 1994 constitutional reform which incorporated article 76 mentioned above, such device was admitted in the constitutional practice even if it had not been expressly provided for. Anyway, the delegations were based on Section 99(2) of the Constitution, establishing that the Executive "issues the instructions and regulations necessary for the enforcement of the laws of the nation, without altering their spirit with regulatory exceptions". These regulations are known as enforcement decrees or decrees regulating laws, and are based on Section 16 of the 1812 Cadiz Constitution. The president issues any such decrees when the application of the laws so requires, considering how accurate they were as enacted by the Congress. A minority portion of authors considered that legislative delegation was based on the doctrine of the implicit powers of the Congress, under the old Section 67(28) of the Constitution, now Section 75(32). ${ }^{51}$ At the same time, there are authors who claim that there are two spheres of legislative delegation in Argentina: a general sphere, including any delegations made to any bodies other than the Executive, based on Section 75 (32); and another specific sphere, which is the one expressly and strictly regulated under Section 76 with the purpose of controlling and mitigating presidential power. ${ }^{52}$

On this aspect, the Argentine Supreme Court issued the Delfino ${ }^{53}$ leading case, in 1927, establishing that there was a key difference between the delegation of power to make the law and to grant certain authority to the Executive or an administrative body, so as to "fill up the details" needed for the execution of such authority. Later, the Argentine Supreme Court went further to state that the regulation should be beyond the details of the law. In Prattico, ${ }^{54}$ it admitted the constitutionality of a decree which had established a minimum rise in salaries given the emergency situation that prevailed at that time, as the

50 CSJN, 4/11/2008, "Colegio Público de Abogados de Capital Federal c/ EN - PEN Ley 25.414 - dto. 1204/01 s/ amparo", Fallos (2008-331-2406).

51 Section 75(32) Const. NAc. empowers the Congress: "To make all appropriate laws and regulations to put into effect the aforementioned powers, and all other powers granted by this Constitution to the Government of the Argentine Nation". See Alberto B. Bianchi, La Delegación legislativa. Teoría de los reglamentos delegados en la Administración Pública 51-2 (1990).

52 See Santiago M. Castro Videla \& Santiago Maqueda Fourcade, La delegación legislativa en la Corte Suprema de Fusticia de la Nación, 2018-III Jurisprudencia Argentina 2, 15 (2018).

53 CSJN, 20/6/1927, "Delfino y Cía.", Fallos (1927-148-430).

54 CSJN, 20/5/1960, "Prattico, Carmelo y otros c/ Basso y Cía.", Fallos (1960-246-345). 
"legislative policy" had been "clearly established". Afterwards, the Supreme Court recognized that its decisions had admitted the delegation of legislative powers beyond the regulatory power in the current wording of Section 99(2) of the Argentine Constitution, such delegation being subject to the limits of Section 28 of the Constitution, i.e. reasonableness. ${ }^{55}$ The admission of legislative delegation to the Executive has deepened in time, being admitted with increasingly broader standards. In Cocchia,${ }^{56}$ the Court affirmed the validity of a decree amending a port activity collective bargaining agreement, as it observed the "legality block". In connection with this first stage before the constitutional reform, Sagüés has clearly said that in the Argentine Supreme Court there was a solid jurisprudential trend that "based on puns and normative costumes, consents to actual delegations of congressional powers to the president, covered by the blanket of the exercise of regulatory powers" ${ }^{57}$

As it was standard practice to make delegations, the 1994 constitutional reform admitted the legislative delegation and subjected it to multiple requirements. The Constitution states that "legislative delegation to the Executive is forbidden except for certain matters in connection with administration or public emergency, with a fixed term for its exercise and within the basis for the delegation established by the Congress". What we see here is that the Constitution establishes a general principle forbidding the delegation to the Executive and, subsequently, establishes the exceptions that may be admitted. For the delegation to be valid, three basic requirements must be met: that the delegation be limited to administration or public emergency matters; that the decrees be issued within the term set for their exercise; and that the decrees adjust to the delegation basis established by the Congress. Section 100(12) adds a fourth requirement - that any such decrees be affirmed by the Chief of the Ministerial Cabinet and subject to the control by the Argentine Permanent Bicameral Committee. Especially in connection with the term "public emergency", authors have criticized that its meaning is not clear, ${ }^{58}$ as resorting to public emergency is "no limit to the Argentine institutional reality". 59 The term "public emergency" is an indeterminate legal concept, and it may cover multiple types of emergencies, such as natural, political, military, administrative, but also economic and social emergencies.

55 CSJN, 17/5/1973, "Potosí S.A. y otros c/ Nación”, Fallos (1973-285-443); 17/3/1988, "D’Anna, Carlos Alberto y otros c/ Siam Sociedad Industrial Americana Maquinarias S. A.", Fallos (1988-311-290).

56 CSJN, 2/12/1993, "Cocchia, Jorge D. c/ Estado Nacional y otro", Fallos (1993-3162624).

57 See Néstor P. Sagüés, Legislación del Poder Ejecutivo detraída del Poder Legislativo (A propósito de los decretos "delegados" y de "necesidad y urgencia"), 1-2 Revista DE Derecho Bancario y de la ActiviDAD FinANCIERA 97, 108 (1991).

58 See Rodrigo Sánchez Brígido, Control de constitucionalidady delegación legislativa, 12 DiscusioNES 81, 83 (2013).

59 See Daniel A. Sabsay \& José Onaindia, La Constitución de los argentinos 255 (2004). 
But it cannot be said that the guidelines in the Constitution have been useful to limit the way in which the legislative delegation has been used. Law No. 25561 was enacted to tackle the 2001 crisis and, under the provisions of Section 76 of the Constitution, declared the public emergency on social, economic, financial, and foreign exchange grounds, and delegated to the Executive various powers for two years. However, such regulation has been extended nine times and has been valid until December 2017, even when the declaration of social emergency was extended to December 2019. It is a problem that the regulation has been in force during an extremely long period, but authors have also highlighted that the delegated powers were dangerously close to the prohibition under Section 29, ${ }^{60}$ providing that the Congress cannot give all public power to the Executive. ${ }^{61}$

Another mechanism used to tackle economic emergency is the decree of necessity and urgency. As explained, this mechanism had not been included in the Constitution until the 1994 constitutional reform. It may be said that decrees of necessity and urgency were forbidden in the beginning. Afterwards, they were admitted, but only as an exception. Their use in practice, however, is regular. The Executive used this tool in the past, for example, in the creation of the "Austral" currency in 1985 with the purpose of tackling the economic crisis in the country at that time. ${ }^{62}$ Another example: in 1990 a decree was issued ordering the repayment of term deposits and the surplus was paid with external bonds. ${ }^{63}$ Both decrees were affirmed by the Supreme Court. In Peralta, the Supreme Court held that the decree was constitutional because of the "serious social risk" situation and the "generalized economic turmoil". The constitutional reform incorporated Section 99(3) with the purpose of regulating these decrees so that their use was limited. First, a general prohibition against their use was provided for — "the Executive Power shall in no event issue provisions of legislative nature" - , and it admitted issuing a decree based on necessity and urgency "only when due to exceptional circumstances the ordinary procedures established under this Constitution for the enactment of laws are impossible to be followed, and when regulations do not involve crimi-

60 Section 29 Const. NAC.: "Congress may not vest on the Argentine Executive - nor may the provincial legislatures vest on the provincial governors - any extraordinary powers or the total public authority; it may not grant acts of submission or supremacy whereby the life, honor, or wealth of the Argentine people will be at the mercy of governments or any person whatsoever. Any acts of this nature shall be utterly void, and shall render those who formulate them, consent to them or sign them, liable to be sentenced as infamous traitors to their fatherland".

61 Alberto B. Bianchi, La emergencia desjuridiza. La emergencia absoluta desjuridiza absolutamente (análisis de la ley 25.587), 187 Debates de Actualidad 23 (2002). See also Law No. 27540 which declared the public emergency on economic, financial, fiscal, administrative, social security, tariff, energy, health and social grounds, and delegated to the Executive various powers, until December 31, 2020.

62 CSJN, 20/4/1989, "Porcelli, Luis A. c/ Banco de la Nación Argentina s/ cobro de pesos", Fallos (1989-312-555).

63 Peralta, Fallos (1990-313-1513). 
Esta revista forma parte del acervo de la Biblioteca Jurídica Virtual del Instituto de Investigaciones Jurídicas de la UNAM

nal issues, taxation, electoral matters, or the system of political parties". The Constitution also set forth a procedure for the ratification of those decrees by the Congress. In such procedure the Permanent Bicameral Committee must be involved, and next the matter must be treated by each of the houses of the Congress, the House of Representatives, and the Senate. However, authors have seriously criticized this regulation: " $\mathrm{t}]$ he way in which the Argentinian constitution regulates emergency decrees is probably one of the worst in Latin America" because "nothing in the constitution deters the president from using emergency powers in an unjustified way if he has the required majorities in one of the houses of congress". ${ }^{64}$ Sagüés also considers that the drafting of the section is faulty, as it is an incomplete regulation, which does not design the final procedure of decrees of necessity and urgency. ${ }^{65}$

\section{Consequences of Economic Emergency and Permanent Economic Emergency}

Economic emergency in Argentina, far from being an exceptional situation, is normal and standard. Virtually all authors agree on this point. Authors specializing in constitutional law, ${ }^{66}$ administrative law $^{67}$ and other areas ${ }^{68}$ agree that Argentina suffers from permanent emergency, and have proposed putting an end to it, as the effects of such emergency are devastating. ${ }^{69}$ It has been claimed that emergency is an everyday reality, and that the exceptional law has become standard practice,$^{70}$ so the concept of "emergency" has been used and abused. ${ }^{71}$

64 See Carlos Rosenkrantz, Romans (not the Judges) Have the Solution, 89 Tex. L. Rev. 1557, 1581 (2011).

65 See Néstor P. Sagüés, Oposición entre un decreto de necesidad y urgencia y una ley de delegación legislativa, 2003-II Jurisprudencia Argentina 1313 (2003).

66 See, e.g., Bianchi, supra note 9, at 141; Gregorio Badeni, Emergencia económica y Estado de Derecho, 2007-A La Ley 1039 (2007); Alberto R. Dalla Vía, La doctrina constitucional de la emergencia y el derecho de propiedad, La Ley: Suplemento Especial 'La emergencia y el caso Massa', 48 (2007); María Angélica Gelli, El caso 'Massa': fin de un capitulo en la pesificación de los depósitos bancarios, 2007-A La Ley 1120 (2007); Alejandro Pérez Hualde, La permanente invocación de la emergencia como base de la crisis constitucional, 2006-A LA LEY 872 (2006); Jorge R. Vanossi, El mar no perdona, 2003-C LA LEY 950 (2003).

67 See, e.g., Pedro J. J. Coviello, El control judicial de la emergencia, 2009-I JurisPrudencia ArGENTINA 1086 (2009); Agustín Gordillo, El Estado de Derecho en estado de emergencia, in EMERGENCIA PÚBlica y REFORMA AL RÉGIMEN MONETARIO 53 (Ricardo L. Lorenzetti, dir., 2002).

68 See, e.g., Ricardo A. Guibourg, Norma, coyuntura y emergencia, 2003-E LA LEY 1061 (2003); Ricardo L. Lorenzetti, Los contratos ante la emergencia económica, 1993-G LA LEY 811 (1993).

69 See Ricardo L. Lorenzetti, Nunca más: Emergencia económica y derechos humanos, 2003-A LA LEY, 1207 (2003).

70 See Tomás Hutchinson, La actual crisis y su solución desde el derecho, REvisTa DE DerEcho PúBlico, La Emergencia económica (SEgunda Parte), 343 (Tomás Hutchinson, dir., 2002).

71 See Miguel A. Ekmekdjian, Manual de la Constitución Argentina 279 (2008). 
The specific issue with this matter is that economic emergency, like some other exceptional mechanisms, has two distinct features: certain prerogatives of power are increased, reinforcing a given body of power; and they create a restriction on individual liberties, rights, and guarantees, especially economic liberties. ${ }^{72}$ Article 16 of the 1789 Declaration of the Rights of Man and of the Citizen provides that "[a] society in which the observance of the law is not assured, nor the separation of powers defined, has no constitution at all". Economic emergency precisely undermines these two aspects. On the one hand, serious restrictions of these rights have been admitted throughout decades, which significantly harms the rights recognized under the Constitution. On the other hand, the principle of the separation of powers has been affected, as economic and social crises have given rise to more demands from the Government, and the Executive has adopted a key role in the adoption of measures to tackle the economic emergency. ${ }^{73}$ Actually, the limitation on economic liberties, mainly the right to property and the liberty to enter into contracts, was made by passing laws. Afterwards, the limitations took effect mainly through decrees of necessity and urgency, and legislative delegation. Along this line, it has been highlighted that economic emergency alters institutional roles: "This is made for the Executive, as it is the only body that makes it on time. The Legislature affirms the measure. Sometimes, the Judiciary amends its effects". ${ }^{74}$ That is why authors are right in pointing that the state of emergency is inversely proportional to the rule of law. ${ }^{75}$ When the Executive resorts to the doctrine of economic emergency, legal uncertainty grows exponentially in the rule of law. ${ }^{76}$ While the Argentine Constitution is a rigid constitution, in Bryce's terms, ${ }^{77}$ as a result of Argentina's "endemic" economic emergency, we have come to have a flexible Constitution system, which may be modified at the Congress's or the Executive's discretion. ${ }^{78}$ It has been said that the doctrine of economic emergency has been systematically repeated to justify the submission of the Constitution to political powers. ${ }^{79}$

Another matter that needs to be considered in connection with the evolution of the doctrine of economic emergency in Argentina is that since the

72 See, e.g., Bidart Campos, supra note 3, at 301; Hernández, id. supra note 16, at 322; EkmEkdjian, id., at 279; Oren Gross \& Fionnuala Ní Aoláin, LaW in times of Crisis: emergency POWERS IN THEORY AND PRACTICE 58 (2006).

73 See Juan S. Ylarri, La división de poderes en la emergencia económica en Argentina, 32 CuEsTIONES Constitucionales 235 (2015).

74 See Pedro J. Frías, ¿Separación de poderes o qué?, La Ley, November 3, 1992, at 2.

75 See, e.g., Dalla Vía, supra note 6, at. 757; Daniel A. Sabsay \& Cristián H. Fernández, El fomento de las industrias y la emergencia económica, 2016-D LA LEY 886 (2016).

76 Roberto J. Vernengo, Nota sobre el recurso a la emergencia como procedimiento derogatorio, 2003-E LA LEY 1084 (2003).

77 See James Bryce, Constituciones flexibles y constituciones rígidas (CEPC ed., 2015).

78 See Bianchi, supra note 61, at 23.

79 See Susana Cayuso, La emergencia económica y la Constitución. Crónica de un pasado y presente contradictorios y de un futuro incierto. En busca de los controles perdidos, 2005-C LA LEY 1319, 1321 (2005). 
Ercolano case, which recognized the emergency police power, and its deeper discussion in Avico, emergency cases usually had to do with social or economic and social emergency, or cases in which the society was affected, but the matter was not extended to the Government itself.

In many decisions the Argentine Supreme Court declared the constitutionality of many regulations passed in exercising the emergency policy; ${ }^{80}$ extension of lease contracts, i.e. stay of the lessor's right to obtain the delivery of the leased property and a reduction in lease payments agreed upon by the parties; ${ }^{81}$ extension of mortgage payment terms, i.e. stay of "any legal remedies or actions against debtors"; 82 stay of evictions, ${ }^{83}$ maximum prices for first-need products or goods, ${ }^{84}$ among other matters. After that line of court decisions - the Peralta case may be considered square one- the emergency police power was extended also to the emergency affecting the Government itself, especially considering public deficit. Also, as we have already seen, a large number of powers of various types were granted upon the Executive. In other cases, the Argentine Supreme Court validated the system to fix salary increases by the Executive and, therefore, the abrogation of conventional rules regulating wages ${ }^{85}$ the limitation of the repayment of term deposits, paying the excess with external bonds; ${ }^{86}$ the consolidation of the Argentine Government's debts; ${ }^{87}$ the reduction in public employees's salaries, ${ }^{88}$ and when the salary decrease ceased, the return of a certain percentage of the discounted sums with the delivery of public securities ${ }^{89}$ the staying of the enforcement of court judgments and arbitral awards ordering the payment of a sum of money entered against the Argentine Government ${ }^{90}$ and the "pesification" of public debt bonds issued by the Argentine Government in U.S. dollars, ${ }^{91}$ among others.

80 Russo, Fallos (1959-243-467).

81 Ercolano, Fallos (1922-136-161).

82 Avico, Fallos (1934-172-21).

83 CSJN, 1/3/1946, "Cello de Ciarrapico, Eugenia C. c/ Marino, Cayetano", Fallos (1946204-195).

84 Vicente Martini, Fallos (1944-200-450).

85 CSJN, 7/8/1990, "Soengas, Hector Ricardo y otros c/ Ferrocarriles Argentinos", Fallos (1990-313-664).

86 Peralta, Fallos (1990-313-1513).

87 CSJN, 22/12/1993, "Hagelin, Ragnar c/ Poder Ejecutivo Nacional s/ juicio de conocimiento", Fallos (1993-316-3176); 19/10/1995, "Cacace, Josefa Erminda c/ Municipalidad de la Ciudad de Buenos Aires s/ accidente - Ley 9688", Fallos (1995-318-1887).

88 CSJN, 2/6/2000, "Guida, Liliana c/ Poder Ejecutivo Nacional s/ Empleo público", Fallos (2000-323-1566).

89 CSJN, 2/12/2004, "Colina, Rene Roberto-Yapura, Sergio Daniel-Vargas, Cesar Eduardo y otros c/ Estado Nacional", Fallos (2004-327-5318).

90 CSJN, 27/12/1990, "Videla Cuello, Marcelo c/ La Rioja, Provincia de", Fallos 1990313-1638).

91 CSJN, 5/4/2005, "Galli, Hugo Gabriel y otro c/ P.E.N. - Ley 25.561 - dtos. 1570/01 y 214/02 s/ amparo sobre Ley 25.561”, Fallos (2005-328-690). 


\section{Judicial Review of Economic Emergency}

The existence of a continued application of economic emergency regulations would not have been possible without the deference of the courts. Throughout decades, the Argentine Supreme Court has tolerated the measures adopted by the branches of government based on economic emergency, admitting in some cases clear violations of rights protected under the Constitution, even if the requirements for the declaration of the emergency were not met.

This issue has been identified by the Court itself, when it said that the history of its decisions shows an extremely broad approach regarding admissible restrictions, ${ }^{92}$ and that this is an approach requiring correction, as its institutional effects have been devastating, given that the rule of law needs a stable system of regulations at the base and not its disregard due to urgent needs. ${ }^{93}$ The study of the main decisions by the Argentine Supreme Court regarding the extent to which the right to property may be affected based on economic emergency shows the clear preponderance of an interpretation tolerating broad restrictions. ${ }^{94}$ Authors have said that the review of the reasonableness of economic emergency regulations made by the Argentine Supreme Court has been weak ${ }^{95}$ and shallow. ${ }^{96}$

Historically, courts have been deferent to the measures adopted to tackle economic emergencies. ${ }^{97}$ The deference to such regulations has been so extreme, however, that it has been even said that economic emergency is a covered political matter. Bianchi actually maintains that while economic emergency has not been dealt with by the courts as a non-justiciable political question, the Argentine Supreme Court has never analyzed in depth the real causes of the economic emergency, or the reasonableness of the measures in light of the causes, so the Court has acted as if this matter would have been excluded from judicial review. ${ }^{98}$

In this context, I believe it is appropriate to propose some guidelines for an appropriate judicial review of this matter. First, it is necessary to highlight that the declaration of economic emergency and the factual circumstances underlying such declaration is a question subject to judicial review, and these

92 Massa, Fallos (2006-329-5913), Lorenzetti, separate opinion; 15/3/2007, "Rinaldi, Francisco Augusto y otro c/ Guzman Toledo, Ronal Constante y otra s/ Ejecución hipotecaria", Fallos (2007-330-855), Lorenzetti and Zaffaroni, separate opinion.

93 CSJN, 18/12/2007, "Longobardi, Irene Gwendoline y otros c/ Instituto de Educación Integral San Patricio S. R. L.”, Fallos (2007-330-5345), Lorenzetti, dissenting.

94 Massa, Fallos (2006-329-5913), Lorenzetti, separate opinion.

95 See, e.g., GeLLI, supra note 6, at 309; Cayuso, supra note 79, at 1323.

96 See Alberto B. Bianchi, Control de Constitucionalidad 39 (2002).

97 See Gustavo Maurino \& Ezequiel Nino, Economic and social rights and the Supreme Court of Argentina in the decade following the 2001-2003 crisis, in Economic AND Social Rights AFter the Global Financial Crisis 299, 322 (Aoife Nolan, ed., 2014).

98 See Bianchi, supra note 6, at 284. 
issues are not non-justiciable political questions. ${ }^{99}$ While the Argentine Supreme Court has admitted that the situation of economic emergency and its declaration are subject to review, I agree with the authors who believe that this issue has been discussed by the Supreme Court as if it were a covered political matter, as the Supreme Court has dogmatically accepted the existence of the emergency as presented by political powers in all instances. My position is that the situation of economic emergency and its declaration through a regulation are a justiciable question. This means that a court has the power to declare that an emergency regulation is unconstitutional when an alleged emergency situation is not such, i.e. when it is false, and therefore may be subject to objection under the Constitution. The consideration of the reality made by the Legislature or, if applicable, the Executive faced with a situation or event considered to be an emergency situation or an event is a justiciable question.

Now, considering the judicial review of economic emergency regulations, one needs to ask whether, in the event of any exceptional circumstances, it is the duty of courts to be more deferent to the measures adopted by the public authorities than during normal times, if it is appropriate to exercise a more intense control or, ultimately, if the judicial review should be as strict during normal times as during exceptional times. Considering the serious excess incurred on this matter during decades, I believe that the judicial review over these regulations should be stricter than during normal times. Not only because the economic emergency admits a higher restriction of economic rights and entails a temporary limitation of the principle of separation of powers, but also because historically there has been abuse by branches of government and scarce judicial review.

\section{Specific Features of Judicial Review Depending on the Type of Regulation that Has Declared the Emergency}

There are certain specific features of judicial review depending on the type of regulation that has declared the emergency. There will be differences depending on whether the regulation is a law in a formal sense, a legislative delegation, or a decree of necessity and urgency.

In connection with the declaration of economic emergency through a formal law, we need to remember that laws enacted by Congress are presumed to be constitutional. That said, this presumption does not entail being absolutely deferent to the lawmaker's judgment. This idea of "full deference" must be rejected, as it may entail considering that the factual circumstance which is the basis to declare the economic emergency is virtually a non-justiciable political question. On the contrary, I believe that the judge may assess the factual circumstances alleged by the lawmaker, without replacing the

99 See Juan S. Ylarri, La emergencia económica. El control de constitucionalidad de la Situación de emergencia económica y su Declaración Normativa (2019). 
lawmaker's discretion. The judge may assess in a specific case that there exist factual circumstances to declare the economic emergency. This does not entail considering that the law is unconstitutional prima facie or that the judges should declare that the regulation is unconstitutional if in doubt. If the judge considers that the factual circumstance does not exist, the judge may hold that the regulation is unconstitutional.

Regarding the legislative powers of the president, delegated decrees and decrees of necessity and urgency, I am of the opinion that these decrees must be subject to a different constitutionality test, other than extreme deference to the decision of political bodies. The "restrictive interpretation" is a judicialreview standard which I consider appropriate for these regulations, taking into account that the Constitution clearly states that these regulations are forbidden. The exercise of legislative powers by the Executive is exceptional and any regulations providing for that exercise must be interpreted restrictively. But a strict scrutiny to consider any such regulations unconstitutional would not be apposite, as one cannot disregard that we are discussing a normative mechanism established in the Constitution, albeit with several limitations. The restrictive interpretation entails that he or she who claims that a decree with legislative content is unconstitutional always has the burden of proving so. But in the event of reasonable doubt regarding its constitutionality, the court must declare that any such regulations are unconstitutional. This is because, in principle, the legislative powers of the president are restricted and their admission is subject to extremely stringent conditions. The Legislature is the body tasked with legislating. The Executive may only legislate in very rare situations. Therefore, the Executive must always provide grounds for the factual circumstances which make it permissible to issue a decree with the force of law. If not, in the event that there is doubt about whether the factual circumstances make it permissible to issue a decree or not, any such regulation will be deemed unconstitutional. Regulations are not always and in every case presumed to be unconstitutional. He or she who alleges must prove. But if there is doubt, the regulation with legislative content must be held to be unconstitutional. Regulations are not always and in every case presumed to be unconstitutional; only in the case of doubt. A large part of authors agree that this restrictive standard must be applied when analyzing the legislative powers of the president. ${ }^{100}$ Other authors believe that the exercise of legislative powers by the Executive is an exception, ${ }^{101}$ so they must be subject to "close

100 See, e.g., Alberto R. Dalla Vía, Control de la emergencia y la legislación delegada, 187 DeBATES DE Actualidad, 15, 17 (2002); Daniel A. Sabsay, Control de la facultad del PEN de dictar decretos de necesidad y urgencia, 2010-A LA LEy 278, 280 (2010); José S. Elias, Urgencia, necesidad y decretos, LA Ley: Suplemento Universidad de San Andrés, December 21, 2010, at 7; Santiago M. Castro Videla \& Santiago Maqueda Fourcade, Aproximación al principio restrictivo en el dictado e interpretación de regulaciones económicas. Aportes sobre sus fundamentos, alcances y aplicaciones, 510 EL DERECHO ADMINISTRATIVO 25, 28 (2017).

101 See María Angélica Gelli, La revisión judicial de la normativa de emergencia, entre las coordenadas del control de constitucionalidad, La Ley: Suplemento Constitucional, August, 2010, at 45. 
scrutiny"102 or "careful examination". 103 Anyway, some authors maintain an opposing position. Barra and Licht assert that the constitutional reform of 1994 designs a new set of functional relations between the President and Congress, notably accentuating the leading role of the former, while strengthening the controlling role of the latter. They believe that a restrictive interpretation of the legislative power of the president denatures the system and tends to nullify, in practice, the institutional progress achieved with the 1994 reform. ${ }^{104}$ I consider this approach wrong, as it cannot be said that the 1994 constitutional reform has been intended to underscore the leading role of the Executive, as constitutional debates clearly show.

Also, the Argentine Supreme Court has outlined several guidelines to control the legislative powers of the president. The most important case in connection with legislative delegation, establishing the criteria to be followed to analyze a legislative delegation, is Colegio Público de Abogados de la Capital Federal. ${ }^{105}$ In this case, the Argentine Supreme Court made express reference to the decisions rendered by the U.S. Supreme Court and held that a key consideration for the validity of the activity performed in the exercise of delegated powers is the creation by the Congress of an intelligible and clear standard or guideline to which the president must be subject. In connection with the basis that the Congress must establish to delegate to the Executive, it held that a delegation without basis is forbidden. And it also stated that when the basis is drafted in a very generic and indeterminate way, the delegated activity will be validated by the courts if the interested party overcomes the burden of establishing that the provision issued by the president realizes the specific legislative policy foreseen by the Congress to pass the pertaining delegation clause. This is how the Argentine Supreme Court resorts to the notion of "restrictive interpretation" mentioned before. This issue was the subject matter of two subsequent cases, Y.P.F. ${ }^{106}$ and Provincia de Santa Fe. ${ }^{107}$

With regard to decrees of necessity and urgency after the 1994 constitutional reform, in Rodríguez ${ }^{108}$ the Argentine Supreme Court virtually abandoned the judicial review of these decrees, arguing that Section 99(3) establishes a

102 See Roberto Gargarella, In Search of Democratic Fustice - What Courts Should Not Do: Argentina, 1983-2002, in Democratization and the Judiciary. The Accountability Function of Courts in New Democracies 132, 139 (Siri Gloppen, Roberto Gargarella \& Elin Skaar, eds., 2004).

103 See Elias, supra note 17, at 422.

104 See Rodolfo Barra \& Miguel Licht, Los decretos de necesidady urgencia, 2016-C La Ley 1157, 1159 (2016).

105 Colegio Público de Abogados de Capital Federal, Fallos (2008-331-2406).

106 C.SJN, 3/7/2012, "Y.P.F S.E. c/ Esso S.A.P.A s/ proceso de conocimiento", Fallos (2012-335-1227).

107 CSJN, 24/11/2015, "Provincia de Santa Fe c/ Estado Nacional s/ acción declarativa de inconstitucionalidad", Fallos (2015-338-1389).

108 CSJN, 17/12/1997, “"Rodríguez, Jorge’ en: 'Nieva, Alejandro y otros c/ Poder Ejecutivo Nacional", Fallos (1997-320-2851). 
specific control by Congress of the decrees of necessity and urgency, for which reason the intervention of the Judicial Power is not justified. Then it handed down many judgments in connection with the aforementioned decrees, admitting its jurisdiction to assess the existence of a state of necessity permitting the issuing of decrees of necessity and urgency. ${ }^{109}$ In some cases, the Court declared the unconstitutionality of the decrees because the problem was an industrial crisis and not one affecting the society at large ${ }^{110}$ or because the decrees were about tax matters, which is forbidden under the principle of legality. ${ }^{111}$ In another case, the Court admitted the reduction in public employees's salaries. ${ }^{112}$

Another important matter is the impact of the ratification by Congress of a decree issued by the Executive. The procedure and the extent of the Congress's intervention were regulated as late as in 2006, when Law No. 26122 was issued. In connection with the surveillance function of the Argentine Congress, the law sets forth that "the rejection of the pertaining decree by both houses of Congress entails its abrogation". I believe that the regulatory law is unconstitutional, as a decree will only be abrogated if both houses of Congress reject it. Requiring the rejection by both houses of Congress of a decree exercising legislative powers is a contradiction, as the passing of a law by the Congress requires the approval of both houses, under the provisions of Section 78, Argentine Constitution. In addition, it is appropriate to clarify that while a decree of necessity and urgency ratified by the Congress has more democratic legitimacy than a decree without that ratification, the truth is that it may happen that the Executive issued a decree of necessity and urgency when the exceptional circumstances are not present, and that the Legislature anyway validates any such decree. In any event, even when there has been approval by the Congress in connection with a decree of necessity and urgency, the decree will be subject to judicial review. Political review is also important, to the extent that it permits the Legislature to invalidate a decree. But just as the judicial review of emergency laws is admitted to verify that the emergency is real, judicial review of the actual existence of a necessity and urgency in the issuance of

109 CSJN, 19/8/1999, "Verrocchi, Ezio Daniel c/ Poder Ejecutivo Nacional - Administración Nacional de Aduanas s/ acción de amparo", Fallos (1999-322-1726; 1/9/2003, "Cooperativa del Trabajo Fast Limitada c/ Poder Ejecutivo Nacional”, Fallos (2003-326-3180); 19/5/2010, "Consumidores Argentinos c/ EN - PEN - Dto. 558/02-SS - Ley 20.091 s/ amparo Ley 16.986", Fallos (2010-333-633); 27/10/2015, "Asociación Argentina de Compañías de Seguros y otros c/ Estado Nacional - Poder Ejecutivo Nacional s/ nulidad de acto administrativo", Fallos (2015-338-1048).

110 CSJN, 2/8/2000, "Risolía de Ocampo, María José c/ Rojas, Julio César y otros s/ ejecución de sentencia (incidente)", Fallos (2000-323-1934).

111 CSJN, 6/6/1995, "Video Club Dreams c/ Instituto Nacional de Cinematografia", Fallos (1995-318-1154); 17/3/1998, "Spak de Kupchik, Luisa y otro c/Banco Central y otro", Fallos (1998-321-366).

112 Guida, Fallos (2000-323-1566). 
the decrees, even if ratified by the Legislature, should also be admitted. While it is appropriate that courts give more deference to decrees of necessity and urgency validated by the Congress - especially if ratified by both houses-, the point is that legislative ratification does not prevent the review by courts for an actual case of necessity and urgency. It is important to remember that the validation of a decree of necessity and urgency is about a regulation in force which has been unilaterally issued by the Executive, in whose preparation there was no appropriate public participation or communication.

\section{Two Dimensions in Exercising Fudicial Review over Situations of Economic Emergency}

In exercising judicial review over situations of economic emergency and its normative declaration, two dimensions may be considered. First, timing, and, second, the correlation that must exist between a regulation - law, legislative delegation, or a decree of necessity and urgency - and the emergency situation it is intended to fight against.

I believe that the time of validity of a regulation may be considered as a factor to establish the scope of the judicial review of an emergency regulation. We need to remember that emergency must be temporal and subject to a brief term, even if this has not been the case of Argentina. Four situations may be identified. First, there is the situation of the scope of the judicial review of the emergency situation at the beginning of the emergency. While the legislative powers of the president must always be interpreted restrictively, in connection with economic emergency formal laws, it may be maintained that at first the courts should be deferential to the regulation adopted and the factual circumstances alleged. This matter has been discussed by Chief Justice Rosenkrantz "more deference should be granted to the government when the emergency has just started than when the emergency has been ongoing for a significant period of time". 113

The fact that courts should have different approaches does not entail that the branches of government are exempt from justifying their decisions. While at this stage it is not appropriate to demand full evidence by political powers with respect to the emergency situation invoked to resort to the exceptional emergency law, in adopting these measures it is necessary to somehow establish the exceptional situation. It is not enough that the Government dogmatically states that there is an emergency. It is true that economic emergency situations require quick governmental action. But, even when these exceptional circumstances demand an urgent solution, any decisions adopted must be reasoned, and must be based on the factual circumstances they seek to fight against. In light of the loose judicial review historically exercised, it is appropriate to state that in the case of emergency regulations the need for justification is all the

113 Rosenkrantz, supra note 64, at 1567. 
more necessary. To start with, the Government must provide arguments for the existence of the factual circumstance of the emergency; in the event of a law, in the message of the bill, in the work in congressional committees, and during the congressional debate. In connection with the legislative powers of the president, in the grounds of the measure, as well as in the file for the measure. This will force the Congress or, if appropriate, the Executive to make a deeper analysis of the existence of the emergency factual circumstance and the measures aimed at fighting against it. This need to provide grounds will somehow result in better analysis of the measures adopted and, therefore, in better regulation.

First, considering this requirement to provide grounds, it is questionable that the Argentine Supreme Court has many times said that the situation of economic emergency is public and evident, ${ }^{114}$ as in court proceedings evident events are exempt from evidence. I believe that it would not be enough to merely admit the situation of economic emergency based on that statement, but that it is appropriate to demand from branches of government more grounds regarding the actual existence of a situation of emergency, and from the courts, a deeper analysis of the matter. That the judges get to know the details of a given situation of emergency is important not only to verify the existence of a true factual circumstance of emergency, but also to establish the end of any such emergency and to review the reasonable relationship between the emergency measure adopted and the emergency situation alleged.

Second, it is necessary to remember that for an emergency law to be valid, it is necessary that it be temporary, i.e. that it be subject to a given term. As the economic emergency is an exceptional situation, it is reasonable to demand that the term be short. It may happen that a regulation intended to tackle the economic emergency is repeatedly extended. In this case, it is appropriate to say that the regulation deserves a higher intensity of judicial review, so the deference to what the political powers have decided decreases. When an emergency measure is extended, further evidence establishing the situation of emergency must be furnished.

Third, it may happen that the economic emergency regulation continues to be extended in time, but afterwards the situation of emergency no longer exists. In the event that the situation of emergency invoked in a given regulation afterwards disappears, it would be appropriate to invalidate the regulation based on the lack of a constitutional cause that justifies its validity, as the powers granted would lack the exceptional circumstances justifying it. This means that the declaration of unconstitutionality after the facts is admitted. The Argentine Supreme Court has admitted the possibility of declaring the unconstitutionality after the facts of a regulation in several cases. ${ }^{115}$ In connection with the eco-

114 See, e.g., Ercolano, Fallos (1922-136-161); Avico, Fallos (1934-172-21); "Inchauspe Hnos., Pedro c/ Junta Nac. de Carnes", Fallos (1944-199-483); Nadur, Fallos (1959-243-449); Russo, Fallos (1959-243-467); Peralta, Fallos (1990-313-1513); Bustos, Fallos (2004-327-4495).

115 CSJN, 3/5/1979, "Valdéz, Julio H. c/ Cintioni, Alberto D.”, Fallos (1979-301-319); 16/12/1993, "Vega, Humberto A. c/ Consorcio de Propietarios Edificio Loma Verde y otro", 
nomic and social emergency, the Argentine Supreme Court held in Mango ${ }^{116}$ that the crisis that had justified a housing emergency law did not exist anymore, so the regulation became unconstitutional.

Fourth, it is necessary to consider the possibility that the emergency regulation is evidently inadequate. It could happen that the emergency regulation be extended for a long period of time, but that the situation of emergency persists. The unreasonableness of the means applied on the basis of inadequacy should be assessed. If the emergency regulation remains valid for a long period and the means applied are not adequate to tackle a given crisis, the review of the reasonableness of the regulation may determine that the measure is not adequate to attain the purpose it seeks. In any case, courts should exercise judicial review with particular care on this matter.

Moreover, I am of the opinion that there must be a relationship of adequacy - or "connection of sense" - in the wording of the Spanish Constitutional Court, between the emergency measure adopted and the emergency situation invoked. ${ }^{117}$ In fact, it could happen that measures be adopted which are allegedly aimed at tackling a specific economic emergency situation, but in the absence of proper grounds, the courts may hold that the measures adopted have no adequacy relationship or connection of sense, directly or indirectly, with the specific factual situation that the regulation is intended to face. On this point, it is appropriate to mention the case of Law No. 25561. In 2002, such regulation declared the public emergency on social, economic, administrative, financial, and foreign exchange matters, and delegated the powers included in the law to the Argentine Executive until the end of 2004. The regulation was in force until December 2017. Regardless of whether the means used were adequate to the purpose sought by the regulation, more than fifteen years after it was passed, it is considered that it cannot be validly said that the factual circumstances on which the approval was based continued.

\section{Fudicial Review of the Existence of an Actual Situation of Economic Emergency}

Now, leaving aside any matters relative to the control regarding timing and the adequacy relationship, I want to highlight certain criteria which the courts may adopt to check the existence of an actual situation of economic emergency.

One of the parameters considered to be correct in the judicial review of the situation of economic emergency is taking into account the Government's

Fallos (1993-316-3104); 27/12/1996, "Chocobar, Sixto C. c/ Caja Nac. de Prev. para el Personal del Estado y Servicios Públicos", Fallos (1996-319-3241).

116 CSJN, 26/8/1925, "Mango, Leonardo c/ Traba, Ernesto", Fallos (1925-144-219).

117 Constitutional Court of Spain, judgments 29/1982, 31/5/1982; 96/2014, 2/6/2014; 27/2015, 19/2/2015; 26/2016, 18/2/2016; 152/2017, 21/12/2017. See JuAN S. Ylarri, Los DECRETOS-LEYES Y EL CONTROL DE LA “EXTRAORDINARIA Y URGENTE NECESIDAD” 101-09 (2019). 
own acts. The judicial review of the actual economic emergency situation must not be limited to the verification of the formal declaration of emergency in a given regulation, but it must also consider other regulations - whether laws or decrees - issued by the Government itself, as those regulations may reveal governmental activities which are not consistent with the emergency situation officially declared. This would amount to normative inconsistency. Hence, this would permit to declare the unconstitutionality of such declaration, considering the lack of constitutional cause giving validity to the emergency regulation. This matter has already been discussed in Mango, already cited, in which, faced with housing shortage, leases were extended and owners were deprived from the use and enjoyment of their property. Among other matters, the Argentine Supreme Court has held that the fact that the situation of emergency did not exist anymore could "likely be inferred from the increase in taxes with which branches of government have levied urban properties lately, which would not be consistent with that situation of emergency". Another normative inconsistency is found in one of the extensions of the Emergency Act, Law No. 25561, and the early payment of the external debt, which was not due yet, with the International Monetary Fund, through decree No. 1599/05 for approximately 10 billion dollars. It was also a contradiction to extend the emergency law and at the same time issue decree No. 2010/09 creating the "Bicentennial Fund for Payment of Debts and Stability", underscoring that there was an unprecedented accumulation of reserves. ${ }^{118}$ This shows that with days of difference there were opposing views regarding the existence of a crisis. One can clearly see that there was inconsistency between the economic emergency declared and the reality. Therefore, it would be possible to hold that such declaration was unconstitutional due to the absence of the constitutional cause validating the emergency regulation.

The Argentine Supreme Court has considered other realities to determine the existence of emergency, such as legislative debates, the message accompanying a bill, or even the work at congressional committees. ${ }^{119}$ The Court also analyzed the content of the grounds of a decree, ${ }^{120}$ the information provided by the Executive in a legal action, ${ }^{121}$ or considered the consistency between the declaration of emergency by the Legislature and by the Executive. ${ }^{122}$ All these have been used by the Court in many cases. The Argentine Supreme

118 See Alberto B. Bianchi, Una reflexión sobre los decretos de necesidad y urgencia en las emergencias generales y de tracto sucesivo (El caso 'Redrado'), 236 El Derecho 845, 848 (2010).

119 Avico, Fallos (1934-172-21); Inchauspe, Fallos (1944-199-483); Videla Cuello, Fallos (1990313-1638).

120 Verrocchi, Fallos (1999-322-1726); Cooperativa del Trabajo Fast Limitada, Fallos (2003-3263180); CSJN, 7/12/2004, "Leguizamón Romero, Abel y otra c/ I.N.S.S.J. y P. s/ ordinario", Fallos (2004-327-5559); Consumidores Argentinos, Fallos (2010-333-633).

121 Avico, Fallos (1934-172-21); Inchauspe, Fallos (1944-199-483); Videla Cuello, Fallos (1990313-1638).

122 Avico, Fallos (1934-172-21); Guida, Fallos (2000-323-1566). 
Court has also considered external information, other than the statements made in the Congress or by the Executive, to decide on the existence of an emergency situation, such as specialized technical reports, ${ }^{123}$ and the recognition of the emergency situation by different sectors, such as the academia, ${ }^{124}$ among others.

In connection with the temporary validity of emergency regulations, the Argentine Supreme Court has held that emergency regulations must contain a defined term. But the Court has not held that emergency regulations should have a determinate term, but that at times it may happen that while emergency regulations must have a term, this term cannot be established beforehand, because of the features of the emergency. Since its early days, the Argentine Supreme Court has held that emergency regulations must be provisional restrictions, ${ }^{125}$ with temporary validity ${ }^{126}$ or transitory in nature. ${ }^{127}$ Anyway, it has admitted that the provisional nature of the emergency "cannot be fixed beforehand in a precise number of years or months. All that it is possible to reasonably state is that the emergency lasts the same as the causes that have given rise to it". ${ }^{128}$ While it may be said that this doctrine is still in force, in Tobar ${ }^{129}$ the Court invalidated a regulation which had admitted a salary reduction for a public employee, as it did not establish that the Government could terminate the emergency measure if the conditions giving rise to it changed.

\section{Reasonableness}

Finally, leaving aside the matter of the existence of an emergency situation, as well as the judicial review of the temporary duration of emergency regulations, it is essential that the courts analyze the reasonableness of the measures adopted. On this point, the Argentine Supreme Court has highlighted that while the emergency may authorize certain restrictions of some individual rights, admitting a temporary limitation of rights with monetary content, that would never justify the denaturation or elimination of the substance of those rights, as the governmental authority cannot validly run through the limit of the reasonableness of the measure. ${ }^{130}$

The control of reasonableness in the Argentine Constitution stems from the harmonious interaction between two constitutional regulations - Section 
14, allowing the Congress to regulate constitutional rights, and Section 28, imposing limits to this regulation, by establishing that any principles, rights, and guarantees recognized under the Constitution cannot be modified by the laws regulating their exercise. That permits to say that a law is reasonable when it has regulated a right without altering its substance. ${ }^{131}$ In connection with the power of the Argentine Congress, the doctrine of the Supreme Court has held that Section 28 of the Constitution has categorically provided that the law cannot modify the principles, guarantees, and rights under the Constitution with the pretext of regulating, as it not possible for the Constitution to destroy what it seeks to protect, and it cannot enshrine its denaturation. ${ }^{132}$

In connection with the development of this principle, authors have tried to delimitate its content. ${ }^{133}$ But, as I have already stated, the review of the reasonableness of economic emergency regulations has been too weak and excessively deferential to the decisions of the branches of government. Authors have tried to outline with more accuracy the scope of the reasonableness analysis of the regulations mostly restricting rights with economic content, especially in connection with the cost-benefit analysis ${ }^{134}$ or the proportionality principle. The proportionality principle has been widely discussed by foreign authors, ${ }^{135}$ and by Argentine authors. ${ }^{136}$ While its application is not exempt from criticism, ${ }^{137}$ the Argentine Supreme Court has held the possibility of applying this principle. It has maintained that to analyze the constitutional validity of a regulation "it is necessary to assess the reasonableness of regulations in terms of the relationship between the means chosen and the aims sought in connection with their adequacy, necessity, and/or proportionality". ${ }^{138}$ But the truth is that the Court has not accurately applied this doctrine. Therefore, it is desirable that the Argentine Supreme Court makes an appropriate reasonableness review of emergency regulations applying the proportionality principle in controlling

131 See Laura Monti, Emergencia y contratos administrativos, La Ley: Suplemento Especial El Contrato Administrativo en la Actualidad, 64, 71 (2004).

132 CSJN, 9/4/1991, "Cortés, Alberto c/ Ministerio de Trabajo y Seguridad Social de la Nación s/ acción de amparo", Fallos (1991-314-225).

133 See Juan F. Linares, RaZonabilidad de las leyes. El 'DEbido Proceso' como garantía innominada en la Constitución Argentina (2002).

134 See, e.g., Estela Sacristán, Control judicial de las medidas de emergencia (a propósito del análisis costo-beneficio), El derecho Administrativo de la Emergencia, IV, 11 1-40 (Guillermo Scheibler, coord., 2005); Juan S. Ylarri, El control de razonabilidad de la emergencia económica: el análisis costo beneficio, LA LEY, AR/DOC/1501, 1-17 (2013).

135 See, e.g., Robert Alexy, Teoría de los derechos fundamentales (CEPC ed., 2007); Carlos Bernal Pulido, El principio de proporcionalidad (2006).

136 See, e.g., Juan Cianciardo, El principio de razonabilidad. Del debido proceso sustantivo al moderno Juicio de proporcionalidad (2004); Laura Clérico, El examen de proporCIONALIDAD EN EL DERECHO CONSTITUCIONAL (2009).

137 See, e.g., Jürgen Habermas, Facticidad y Validez 312 (Trotta ed., 1998).

138 CSJN, 28/6/2011, "Aceval Pollacchi, Julio César c/ Compañía de Radiocomunicaciones Móviles S. A. s/ despido", Fallos (2011-334-799). 
economic emergency regulations ${ }^{139}$ and put an end to an interpretation which is highly deferential to economic emergency regulations, as it is even possible to say that the control of the reasonableness of these regulations has been relinquished in actual practice.

\section{Conclusion}

For almost a century, Argentina has been under permanent economic emergency. To face these emergency situations, different types of regulations have been issued. While in principle the declaration of the existence of an economic emergency is the province of the Congress, the truth is that throughout decades the Executive has been having an increasingly prevailing role by issuing delegated decrees, with a delegation by the Congress, or by issuing decrees of necessity and urgency. The Argentine Supreme Court has established certain requirements for economic emergency regulations to be valid. However, as it has been explained, the branches of government have abused these regulations. At the same time, courts have been extremely deferential to the decision of the Congress or the president. This is why a change of the judicial review of economic emergency regulations is imperative. It is also necessary to apply a restrictive interpretation of such regulations, with the purpose of adequately protecting economic liberties and, therefore, making it possible that the Constitution is observed.

139 See Juan S. Ylarri, El principio de proporcionalidad en la emergencia económica, MicroJuris, April 4,2015 , at 1-21. 


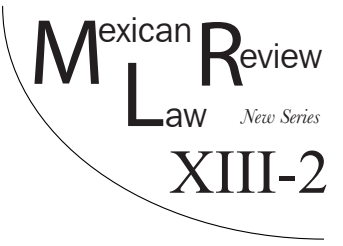

\title{
MEXICO'S LEGAL FRAMEWORK REGARDING WASTEWATER MANAGEMENT: A CASE STUDY OF BAJA CALIFORNIA SUR*
}

\author{
Ana Teresa Valdivia Alvarado** \\ Alba E. GÁMEz ${ }^{* * *}$ \\ Luis Felipe Beltrán Morales**** \\ Alfredo ORTEGA-RubIO ${ }^{* * * * * *}$
}

\begin{abstract}
ABSTRAGT: Wastewater is one of the principal causes of coastal ecosystem pollution and poses a threat to food security, drinking water access, public health, and ecosystem survival. However, wastewater can also be a reliable alternative source of water, provided specific changes are made. Mexico's extensive and complex legal framework involving various governmental agencies and overlapping jurisdictions makes it difficult to ascertain the specific responsibilities of various actors and enforce accountability in the area of wastewater management. The aim of this paper is to analyze the relevant law in order to determine whether it is the legislation itself which is generating adverse environmental impacts, or whether these impacts are the result of the wastewater management system as implemented. In this study, we analyze the legal framework applicable at each
\end{abstract}

* This article was developed with economic support from the Mexican Council of Science and Technology (CONACyT) Natural Protected Areas Thematic Research Network (Red Temática de Investigación en Áreas Naturales Protegidas, RENANP), CONACyT Basic Science project 251919, and the Northwest Center for Biological Research (CIBNOR). The authors wish to thank the anonymous reviewers and Dr. John Ackerman for their helpful comments and for taking the time to point out options to improve our manuscript.

** PhD. Candidate in Use, Management and Conservation of Natural Resources at Northwest Biological Research Center (CIBNOR), Mexico; LL.M. The George Washington University, LLB. Universidad Anáhuac; Email: avaldivia@pg.cibnor.mx.

*** PhD. In International Relations at Essex University, UK. Professor-Researcher at Autonomus University of Baja California Sur (Universidad Autónoma de Baja California Sur), Mexico; Email: agamez@uabcs.mx.

**** PhD. In Environmental Science at EULA Center (Europa-América Latina), University of Concepción, Chile. Researcher at Northwest Biological Research Center (CIBNOR), Mexico; Email: lbeltran04@cibnormx.

******* PhD. In Ecology at National Polythecnical Institute, Mexico. Researcher at the Northwest Biological Research Center (CIBNOR), Mexico; Email: aortega@cibnormx. 
Esta revista forma parte del acervo de la Biblioteca Jurídica Virtual del Instituto de Investigaciones Jurídicas de la UNAM

of the three levels of government in order to clarify the connections between these governmental entities from a perspective that has not been previously developed, which will be a useful point of departure for future research. To this end, the state of Baja California Sur (in northwestern Mexico) is presented as a case study insofar as it is representative of vulnerable coastal regions facing water scarcity. The methodology and systematic analysis of wastewater regulations employed in this paper facilitate both an evaluation of the efficacy of the current legal framework surrounding wastewater management, as well as the identification of changes needed in order to achieve environmental sustainability and protect water resources for present and future generations.

KEYWORDS: Wastewater, legal framework, water management, wastewater regulation, Baja California Sur.

RESUMEN: Las aguas residuales representan uno de los factores que más contaminan los ecosistemas costeros, poniendo en riesgo la seguridad alimentaria, el acceso al agua potable, la salud de la población y de los ecosistemas. Sin embargo, las aguas residuales pueden ser una fuente alternativa y confiable de agua, en la medida en que haya cambios en varios ámbitos. En México, un reto principal deriva del extenso y complejo marco regulatorio sobre las aguas residuales, que dificulta la definición de responsabilidades y de rendición de cuentas, especialmente en el caso de las diferentes instancias de gobierno relacionadas con el tema. En este artículo se analiza el marco legal para determinar si la legislación en si misma representa un factor que contribuye a la mala gestión de las aguas residuales, o si bien los problemas ambientales radican en el mal manejo. Así, se caracteriza el marco legal aplicable a los tres niveles de gobierno para dilucidar las conexiones entre las diferentes leyes, desde una perspectiva no desarrollada previamente, lo que puede ser un insumo útil para investigaciones futuras. Se toma como caso de estudio al estado de Baja California Sur, ya que es una zona costera vulnerable que actualmente enfrenta un grave problema de escasez de agua. La metodología y el análisis sistemático del marco regulatorio de las aguas residuales propuesto permite evaluar la eficacia del marco legal y determinar las reformas necesarias para un manejo sustentable de las aguas residuales, cuidando con ello el agua para ésta y futuras generaciones.

Palabras Clave: Aguas residuales, marco legal, regulación de aguas residuales, gestión del agua, Baja California Sur.

\section{TABle of Contents}

I. INTRODUCTION

II. Legal Background Regarding Wastewater in Mexico.............. 120

III. Theoretical FramewOrk ..................................................... 122

IV. Study Area: Baja Galifornia Sur ......................................... 124

V. Systematic Analysis of the Legal Framework Regarding WASTEWATER 
1. Constitutional Analysis

2. Analysis of the Spheres of Validity

3. Hierarchization of Sources .....

4. Dynamic Analysis

\section{INTRODUCTION}

Water, a vital resource essential for life, has also become a pressing national security matter ${ }^{1}$ requiring international cooperation. The international community has confronted the problem of water quality and availability by gradually adopting principles for the integrated management of water resources. This has led many countries to adopt policies, strategies, domestic laws, and information systems, as well as coordination, financing, and enforcement mechanisms ${ }^{2}$ aimed at regulating the water management cycle from freshwater extraction, distribution and use, to reclamation, treatment, reuse and ultimate return to the environment. ${ }^{3}$

Despite these efforts, once water has been used and becomes wastewater, ${ }^{4}$ its subsequent fate is often ignored. Wastewater is one of the principal causes of water and coastal ecosystem pollution, and poses a threat to food security, drinking water access, public health, and ecosystem survival. Nevertheless, wastewater management is one of the most overlooked factors in Mexican environmental policy. This neglect has not only led to increased poverty but has also become an impediment to economic development. ${ }^{5}$ A desirable paradigm change would include wastewater as a reliable alternative source of water. This would require a change in how wastewater is managed, "shifting

1 Louise Rolland \& Yenny Vega Cárdenas, La Gestión del Agua en México, 6 (2) Polis. InvesTigacion y AnAlisis Soc. y Psi. 34 (2010).

2 U.N., World Summit on Sustainable Development, working group WEHAB. Johannesburg, (Aug. 26-Sept. 4, 2002), available at http://www.un.org/spanish/conferences/wssd/basicinfo.html.

3 World Water Assessment Programme, Wastewater: The Untapped Resource. The United Nations World Water Development Report 2017. UNESCO, 18,19 (2017).

4 See, Article 3, VI, of the National Water Law: Wastewater is defined as water of varied composition consisting of discharges from treatment plants and from urban public, domestic, industrial, commercial, service, agricultural, livestock-related, and other uses in general, as well as mixtures thereof. Wastewater discharges are classified as municipal or non-municipal. Municipal wastewater composition varies depending on the diversity of the pollutants released by the various domestic, commercial, and institutional sources. These discharges are collected by municipal sewer systems and routed to treatment plants under municipal jurisdiction. Non-municipal discharges are discharges generated by other uses, such as industry and agriculture, which must be treated by treatment plants at the generator's expense.

5 E. Corcoran et al., eds., Sick Water? The Central Role of Wastewater Management, in Sustainable Development: A Rapid Response Assessment, UNEP, UN-HABITAT, GRID-Arendal, 88 (2010). 
the paradigm from 'treatment and disposal' to 'reuse, recycle and recover"'. ${ }^{6}$ This paradigm shift could transform wastewater from an environmental problem into a solution to one of the most significant challenges facing humanity.

The prevalence of wastewater-related issues and problems tends to vary in direct proportion to a country's income level. On average, high-income countries treat about $70 \%$ of the wastewater they generate, whereas this percentage drops to $38 \%$ for medium-income countries, $28 \%$ for lower-income countries, and $8 \%$ for the lowest-income countries. ${ }^{7}$ The absence of adequate wastewater treatment systems exacerbates poverty and increases health problems by directly exposing the population to polluted wastewater.

In Mexico, wastewater is reused in large quantities. Despite the fact that $94 \%$ of the water supply destined for individual use has been disinfected, only $58.3 \%$ of the wastewater collected through sewer systems is treated to improve its quality before being reused or returned to a body of water. ${ }^{8}$ As a result, water for human use, whether taken from surface or groundwater sources, is often contaminated by pathogenic microorganisms, particularly fecal coliforms. ${ }^{9}$ Recognizing the gravity of this problem, Mexico has adopted the Agenda 2030 and its sustainable development goal (SDG) regarding water resources, both of which address issues beyond water supply and treatment. In particular, the SDG Target 6.3 provides that signatory countries commit, "by 2030, [to] improve water quality by reducing pollution, eliminating dumping and minimizing release of hazardous chemicals and materials, halving the proportion of untreated wastewater and substantially increasing recycling and safe reuse globally". ${ }^{10}$

Achieving these goals will require a paradigm change that envisions wastewater as a solution to the problem of inadequate water supply and treatment. Such a change, however, depends on the existence of a comprehensive and effective legal framework concerning wastewater which ensures compliance by both individuals and organizations in order to promote the collective interest. ${ }^{11}$ Thus, public policies and wastewater management goals need to be implemented in the form of specific laws and regulations which clearly define the responsibilities assigned to the various involved parties. The effectiveness

6 World Water Assessment Programme, supra note 3, at 24.

7 T. Sato et al., Global, regional, and country level need for data on wastewater generation, treatment, and use, 130 Agricultural Water Management 1 (2013), available at: dx.doi.org/10.1016/j.agw at.2013.08.007.

8 Comisión Nacional del Agua [CONAGUA], Estadísticas del Agua en México (2017), available at http://files.conagua.gob.mx/conagua/publicaciones/Publicaciones/EAM2016.pdf.

9 Julia Carabias \& R. Landa, Agua, medio ambiente y sociedad: hacia la gestión inteGRAL DE los RECURSOS hídricos En MéXico 221 (UNAM-GOLMEX: Fundación Gonzalo Río Arronte, 2005).

10 U.N. General Assembly, Transforming Our World: the 2030 Agenda for Sustainable Development, resolution adopted by the General Assembly, A/RES/70/1 (25 September 2015), available at wrere.un.org/ga/search/view_doc.asp?'symbol=A/RES $/ 70 / 1$ ELLang $=E$.

11 World Water Assessment Programme, supra note 3. 
of such laws largely depends on how these responsibilities are defined and implemented at the federal, state, and municipal levels. ${ }^{12}$

The problems associated with wastewater management in Mexico begin with the country's regulatory framework, which is characterized by overlapping federal, state, and municipal regulatory layers which inhibit compliance. Specific case studies examining these issues in the national context are needed to help communities understand and anticipate what constraints or problems they may face when attempting to better manage their water resources. This paper provides a comprehensive overview of the existing legal framework regarding wastewater resources and discharges, and a systematic assessment of its efficacy, at all three levels of government.

The state of Baja California Sur (BCS) was selected for examination because it is representative of regions that are highly vulnerable to water scarcity. In that state, the principal source of water is aquifer extraction which highlights the importance of the link between water quality and availability given the fact that overexploitation has given rise to saline water intrusion. Wastewater could become an additional source of water for the state, but the current legal framework complicates and impedes its efficient use and management. A comprehensive, systematic analysis of wastewater regulations is urgently needed to assist in the formulation of new public policies which encourage wastewater treatment and reuse in order to confront the problems of water quantity and quality in BCS.

In order to perform a systematic analysis of the existing wastewater legislation at the federal, state, and municipal levels, a comprehensive survey of documents on environmental law and the related legal framework regarding wastewater resources was conducted using the methodology developed by Dr. María del Carmen Carmona. ${ }^{13}$ Her approach provides a new perspective as well as a legal basis for analyzing the effectiveness of legal frameworks so that legislative reforms can be envisioned and proposed which both encourage compliance and facilitate enforcement. ${ }^{14}$

Carmona's methodological framework is comprised of the following steps: a constitutional analysis; a hierarchization of the sources of law; an analysis of the spheres of validity (spatial, temporal, material, and personal); and, a dynamic analysis. We will begin with a constitutional analysis, identifying the specific constitutional provisions that provide the foundation for the legal framework regarding wastewater. Once this has been completed, a deeper analysis of the specific wastewater-related provisions may be performed. This method is predicated on a formal analysis, that is, a systematic analysis of the sources of

$12 I d$. at 45.

13 María del Carmen Carmona Lara, Bases para el Conocimiento Integrado del Derecho Ambiental, in Temas Selectos de Derecho Ambiental 19-45 (Cámara de Diputados LXI Legislatura, Comisión de Medio Ambiente y Recursos Naturales, Palacio Legislativo ed., 2010).

14 Id. at 19, 20. 
Esta revista forma parte del acervo de la Biblioteca Jurídica Virtual del Instituto de Investigaciones Jurídicas de la UNAM

law and their hierarchical structure, as well as an explication of the particular type of legal system in which they are embedded. ${ }^{15}$

\section{Legal BAGKground Regarding Wastewater in MeXico}

The Mexican regulatory framework regarding wastewater has two sources, one stemming from water-related legislation, the other from environmental law. Water law in general predates environmental law as such. In this way, the first relevant statute to be enacted was the Mexican Transportation Act of 1888 (Ley General de Vias Generales de Comunicación). This was followed by the Use of Federal Waters Act of 1910 (Ley sobre Aprovechamiento de Aguas de Furisdicción Federal), the Irrigation with Federal Waters Act of 1926 (Ley sobre Irrigación con Aguas Federales), the Nationally Owned Waters Act of 1934 (Ley de Aguas de Propiedad Nacional), and finally, the Federal Waters Act of 1972 (Ley Federal de Aguas). Subsequent amendments and additions to the Federal Waters Act resulted in the current National Waters Act of $1992,{ }^{16}$ which was last amended in 2020.

The first environmental regulations developed out of a need to protect human health from various sources of pollution. The first such law to be enacted was the Federal Environmental Pollution Prevention and Control Act of 1971 (Ley Federal para Preveniry Controlar la Contaminación Ambiental). ${ }^{17}$ It had three regulations:

- Water Pollution Prevention and Control Regulation (Reglamento para la Prevención y el Control de la Contaminación de las Aguas). ${ }^{18}$

- Regulation for the Prevention and Control of Marine Pollution from Waste Dumping and Other Materials (Reglamento para la Prevención y el Control de la Contaminación del Mar por vertimiento de desechos y otras materias). ${ }^{19}$

$15 I d$. at 28.

16 Ley de Aguas Nacionales [L.A.N.] [National Water Act] as amended, Diario Oficial de la Federación [D.O.F], 1 de diciembre de 1992 (Mex.).

17 Ley Federal para Prevenir y Controlar la Contaminación Ambiental [L.F.P.C.C.A.] [Federal Environmental Pollution Prevention and Control Act $]$ as amended, Diario Oficial de la Federación [D.O.F], 23 de marzo de 1971 (Mex.).

18 Reglamento para la Prevención y el Control de la Contaminación de las Aguas [R.P.C.C.A.] [Water Pollution Prevention and Control Regulation] as amended, Diario Oficial de la Federación [D.O.F], 29 de marzo de 1973 (Mex.).

19 Reglamento para la Prevención y el Control de la Contaminación del Mar por Vertimiento de Desechos y otras Materias [Regulation to Prevent and Control of Marine Pollution from Dumping of Waste and Other Materials] as amended, Diario Oficial de la Federación [D.O.F], 23 de enero de 1979 (Mex.). 
- Regulation for the Prevention and Control of Air Pollution Originating from the Emission of Smoke and Dust (Reglamento para la Prevención y el Control de la Contaminación Atmosférica originada por la emisión de humos y polvos). ${ }^{20}$

After 1971, a number of constitutional and legal reforms were enacted with the objective of protecting the environment; however, these reforms continued to be primarily targeted to the protection of human health. In terms of institutional changes, in 1972, the post of Environmental Improvement Undersecretary (Subsecretaria de Mejoramiento al Ambiente) was created within the Secretary of Health. However, the powers deriving from the Federal Environmental Pollution Prevention and Control Act were sector-specific, with each federal department being assigned distinct responsibilities. For example, the Secretary of Water Resources (Secretaría de Recursos Hidráulicos) had jurisdiction over the prevention and control of water pollution, the Secretary of Agriculture and Livestock (Secretaría de Agricultura y Ganadería) oversaw the prevention and control of soil contamination, and the Secretary of Industry and Commerce (Secretaria de Industria y Comercio) was responsible for the prevention of contamination resulting from industrial and commercial activity. ${ }^{21}$

It was not until 1982 that the first Federal Environmental Protection Act (Ley Federal de Protección al Ambiente) was enacted. Pursuant to this Act, various environmental responsibilities were consolidated and centralized which was a significant first step toward the effective protection of the environment and the nation's natural resources. This Act was ultimately superseded by the current Mexican Environmental Protection Act of 1988 (Ley General del Equilibrio Ecológico y la Protección al Ambiente). ${ }^{22}$ LGEEPA has been subsequently amended several times, most significantly in 1996. LGEEPA's Title Four, "Environmental Protection", Chapter III, "Prevention and Control of Pollution of Water and Aquatic Ecosystems", contains the wastewater-related provisions. ${ }^{23}$

The Mexican Constitution (Constitución Politica de los Estados Unidos Mexica$n o s)^{24}$ has also undergone several revisions and amendments, most significantly

20 Reglamento para la Prevención y el Control de la Contaminación Atmosférica originada por la emisión de humos y polvos [Regulation to Prevent and Control Air Pollution from Smoke and Dust] as amended, Diario Oficial de la Federación [D.O.F], 17 de septiembre de 1971 (Mex.).

21 Tania García López, Derecho Ambiental Mexicano, Introducción y Principios 29,30 (Bosch, S.A. ed., 2013).

22 Ley General del Equilibrio Ecológico y la Protección al Ambiente [L.G.E.E.P.A.] [Mexican Environmental Protection Act] as amended, Diario Oficial de la Federación [D.O.F], 28 de enero de 1988 (Mex.).

23 Id. See, articles 117-133.

24 Constitución Política de los Estados Unidos Mexicanos [Const.] [Mexican Constitution] as amended, Diario Oficial de la Federación [D.O.F], 5 de febrero de 1917 (Mex.). Available at http://wrere.diputados.gob.mx/LeyesBiblio/index.htm. 
to Article 4, in 1999 and 2012, which introduced the following rights fundamental to wastewater regulation:

All persons have the right to a healthy environment for their development and well-being. The State shall guarantee the effectiveness of this right. Anyone who causes environmental damage or degradation incurs the corresponding liability, as prescribed by law. ${ }^{25}$

Everyone has the right of access to, disposal of, and treatment of sufficient quantities of clean water for personal and domestic consumption, in an acceptable form and at an affordable cost. The State shall guarantee this right and the law shall establish the bases, assistance, and modalities for equitable and sustainable access to, and use of, water resources, establishing the participation of the Federation, the federative entities [states], and the municipalities, as well as the participation of the citizens, in the achievement of these ends. ${ }^{26}$

Another federal law related to wastewater regulation is the Federal Duties Act (Ley Federal de Derechos). The 1982 version of this Act included fees for the use and appropriation of national surface water and groundwater, and the 1991 version was amended to include the assessment of fees for contaminated wastewater discharges.

The Water Pollution Prevention and Control Regulation of 1973 was abolished by the Regulations of the National Waters Act. ${ }^{27}$ Due to the superseding authority of the National Waters Act over LGEEPA, this new regulation became the effective regulatory law governing the prevention and control of water pollution. ${ }^{28}$ This legislative history reveals an abundant but fragmented legal framework regarding wastewater regulation. Due to the different levels of jurisdiction, spheres of application, and hierarchies, the resulting operational framework is complex and can be difficult to navigate.

\section{TheOrETICAL FraMeWORK}

Since the literature on wastewater legislation is limited, we opted to make use of an indirect bibliography in order to examine current wastewater regulation. Agenda 21, a non-binding action plan developed during the Earth Summit of the United Nations Conference on Environment and Development held in Rio de Janeiro, Brazil, in 1992, establishes that all member states, according to their capacity and available resources, should implement effective programs to prevent and control water pollution. Such programs are to be based

25 Id., as amended, Diario Oficial de la Federación [D.O.F], 28 de junio de 1999 (Mex.).

26 Id., as amended, Diario Oficial de la Federación [D.O.F], 8 de febrero de 2012 (Mex.).

27 Reglamento de la Ley de Aguas Nacionales [Regulations of the National Waters Act] as amended, Diario Oficial de la Federación, 12 de enero de 1994 (Mex.).

28 Raúl Brañes, Manual de Derecho Ambiental Mexicano 432 (Fondo de Cultura Económica ed., 770, 2000). 
on a combination of strategies designed to reduce pollution, assess environmental impacts, and uphold mandatory standards applicable to wastewater discharges. ${ }^{29}$

Agenda 21 sets forth the following objectives related to the prevention and control of water pollution: ${ }^{30}$

- Apply the "polluter pays" principle to the various sources of pollution.

- Promote the construction of treatment facilities for domestic and industrial wastewater and develop appropriate technologies to that end.

- Establish standards regulating wastewater discharges.

- Introduce the "precautionary principle" into water quality regulation, with special attention given to minimizing contamination, preventing contamination via the use of new technologies, reducing point-source contamination, and developing systems to recover, recycle, treat, reuse, and ultimately eliminate wastewater.

- Promote the treatment of municipal wastewater for reuse without risk to agriculture and aquaculture.

Achieving these objectives depends on the existence of both effective institutions and a corresponding, complementary legal framework at the national level. In Mexico, the principles underlying these objectives do, in fact, appear in the regulatory framework. However, the persistence of wastewater-related problems leads to the conclusion that either the current laws are inadequate, or they are not being effectively applied or enforced.

According to Anthony Heyes, given both the increasing number and increasingly coercive nature of environmental laws, one might assume that levels of compliance have improved. However, compliance depends on stable and predictable enforcement. To this end, governmental authorities must implement an effective compliance program. ${ }^{31}$ At the outset, any compliance regime requires the dissemination of clear, accurate information that is easily accessed, interpreted and understood. ${ }^{32}$ In the area of wastewater regulation, this first step involves compiling and consolidating all applicable laws and regulations. Once this has been done, the effectiveness of the entire regulatory apparatus in promoting the sustainable management of water resources can be assessed, and the need for further amendments or reforms can be more eas-

29 U.N., Agenda 21, Chapter 18, Protection of the Quality and Supply of Freshwater Resources: Application of Integrated Approaches to the Development, Management and Use of Water Resources, (1992), available at https://sustainabledevelopment.un.org/content/documents/Agenda21.pdf.

30 Id. at 18.40.

31 Anthony Heyes, Implementing Environmental Regulation: Enforcement and Compliance, 17 JourNAL of Regulatory Economics, 23 (2000).

32 Consejo Estatal de Ecología Hidalgo, Indicadores Ambientales del Estado de HiDALGO, 71 (2003), available at http://wwre.semarnat.gob.mx/archivosanteriores/informacionambiental/Do cuments/04_indicadores/indicadores_2003_hidalgo.pdf. 
ily identified. As Ortiz Rendón has observed, "Without accurate knowledge of the problem, it is impossible to implement sustainable policies to address them". 33

Along these same lines, Carmona points out that the OECD already has identified one particular challenge facing Mexico that pertains to water management in Mexico: the need for implementing legislation targeted to the reduction of pollution and the protection of nature, including increasing the number of inspections and the level of regulatory compliance. ${ }^{34}$ In that regard, as González states, "Good water governance calls for the use of mechanisms such as laws and regulations, effective policy, adequate governmental organization, requisite infrastructure, and a culture of efficient use and preservation of water resources". ${ }^{35}$ González maintains that sustainable development also requires an explicit system of incentives to encourage the efficient and responsible use of water, and to help preserve water quality. Such a system can only be achieved with a corresponding legal framework that specifically articulates the nation's current needs. He emphasizes that the law should be simple, clear, easy to understand, straightforwardly applicable, and include regulations that define and explain all relevant procedures. ${ }^{36}$

With the foregoing in mind, our analysis will focus on the Mexican legal framework and international guidelines pertaining to wastewater, since they are the platform for the effectiveness of water management policies and enforcement mechanisms, that, as Gilabert-Alarcón states, change with each new presidential administration, resulting in the deterioration in both water and sanitation services. ${ }^{37}$

\section{Study Area: Baja California Sur}

BCS is a semi-desert state in northwestern Mexico occupying the southern half of the Baja California peninsula. It is bounded on the north by the state of Baja California, which lies above the 28th parallel, on the east by the Gulf of California, and on the south and west by the Pacific Ocean. It oc-

33 G. A. Ortiz Rendón, Administración del Agua. Aplicación de instrumentos de poLítica HIDRÁUliCa En ESCEnARIOS ALTERnativos 227 (Instituto Mexicano de Tecnología del Agua, 2001).

34 María del Carmen Carmona Lara, La gestión integrada por cuencas y la garantía del derecho humano al agua en México, in Obra Jurídica Enciclopédica, Derecho Ambiental 73-98 (Porrúa, 2014).

35 FernandoJ. González Villarreal, Gobernabilidad Hidráulica, in La Gobernanza del Agua: un Desafío actual 137,138 (Instituto Mexicano de Tecnología del Agua, 2012).

36 Id. at 139.

37 Christian Gilabert-Alarcón et al., Regulatory Challenges for the Use of Reclaimed Water in Mexico: A Case Study in Baja California, 10 WATER 22 (2018), available at https://res.mdpi.com/d_attachment/ water/water-10-01432/article_deploy/water-10-01432.pdf. 
Esta revista forma parte del acervo de la Biblioteca Jurídica Virtual del Instituto de Investigaciones Jurídicas de la UNAM

cupies $73,475 \mathrm{~km}^{2}$, or $3.8 \%$ of Mexico's territory, ${ }^{38}$ and is divided into five municipalities, from north to south: Mulegé, Loreto, Comondú, La Paz, and Los Cabos.

\section{Map of Baja Galifornia Sur ${ }^{39}$}

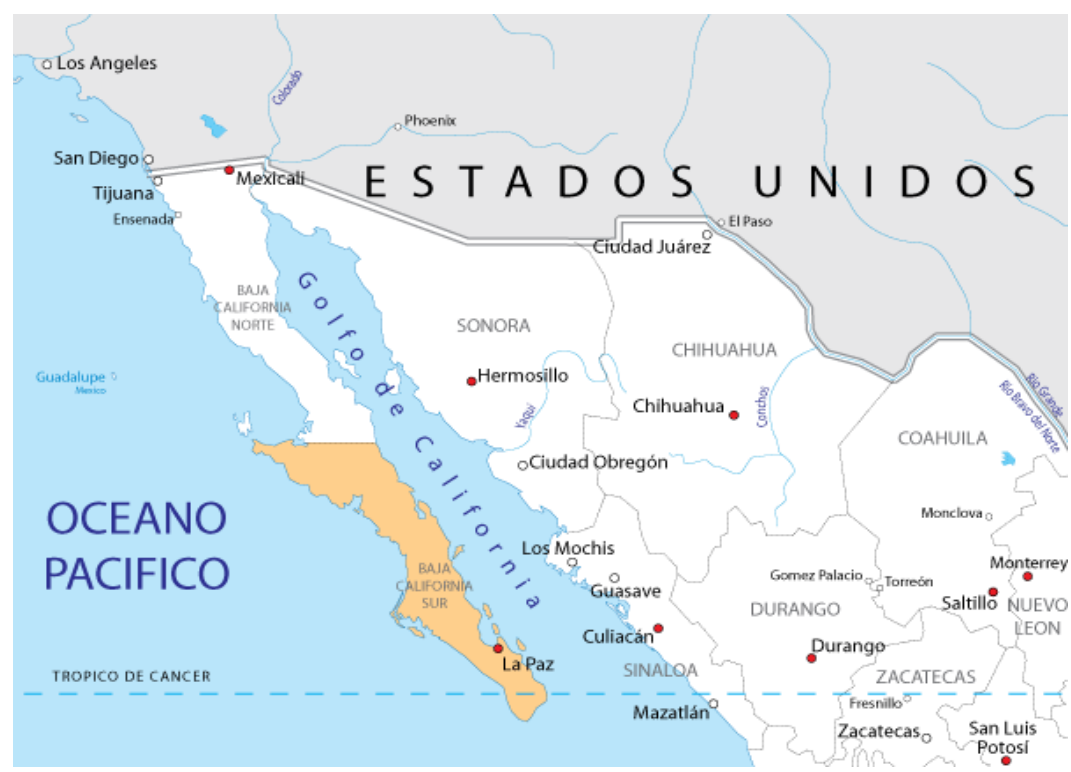

The Baja California peninsula is located in one of the most arid regions of the country with a mean annual precipitation $77 \%$ lower than the national average, which limits its prospects for social, economic, and environmental development. ${ }^{40}$ BCS receives $0-400 \mathrm{~mm}$ of rainfall annually. At higher elevations, rainfall reaches an average of $700 \mathrm{~mm}$, while the mean total annual precipitation in the state is less than $200 \mathrm{~mm} .{ }^{41}$ The climate at lower elevations is dry desert; the temperature exceeds $40^{\circ} \mathrm{C}$ in the summer and falls below $0^{\circ} \mathrm{C}$ during the winter. Only the Los Cabos region has a sub-humid, temperate climate due to the influence of cyclones. ${ }^{42}$

38 Gobierno de Baja California Sur, Geografía, (Nov. 5, 2015), available at http://wrwre.bcs. gob.mx/conoce-bcs/geografia/.

39 Geoatlas.com, Map of Baja California Sur, (Feb. 19, 2020), available at http://wrwremap-ofmexico.co.uk/espanola/mapa-de-bajacaliforniasur.htm.

40 Comisión Nacional del Agua [COnagua], Programa Hídrico Regional, Visión 2030, Región Hidrológico-Administrativa I Península de Baja California (2012), available at wrere.conagua.gob.mx.

41 Instituto Nacional de Estadística, Geografía e Informática [INEG], Geografía e Informática. 2018. Gú́NTAMe, (Jun. 5, 2018), available at http://wrww.cuentame.inegi.org.mx/mono grafias/informacion/bcs/territorio/clima.aspx?tema $=$ me $\mathcal{E}_{e}=03$.

42 Gobierno de Baja California Sur. Clima, (Nov. 5, 2015), available at http://wrerw.bcs.gob. $m x /$ conoce-bcs/geografia/. 
The state's population is 712,029, which amounts to $0.6 \%$ of Mexico's inhabitants. ${ }^{43}$ The census currently underway is expected to increase that number to one million. The tourism boom in Los Cabos has been a strong driver of both immigration and water demand, increasing the pressure on the region's water resources. ${ }^{44}$ From 2000 to 2010, the population of BCS grew by $50 \%$, resulting in a corresponding reduction in annual per capita water availability, which fell to $785 \mathrm{~m}^{3}$. This state is, therefore, classified as one experiencing water scarcity. ${ }^{45}$

The BCS State Climate Action Plan acknowledges that the only reliable source of fresh water in the state is groundwater, which is recharged by flooding and runoff from intense rainfall. However, groundwater is being mined from all available aquifers at a higher rate than it can be recharged, resulting in seawater infiltration. ${ }^{46}$ The main sources of water pollution in the state are untreated municipal, industrial, and agricultural discharges, the low efficiency of treatment plants, infiltration from septic systems, and inadequately sited or uncovered garbage dumps. ${ }^{47}$

The Vision 2030 Regional Water Program recognizes that the water infrastructure in Baja California is insufficient and that wastewater treatment does not, in most cases, comply with the Official Mexican Standard of quality. It further states that there is widespread noncompliance with laws and regulations governing wastewater control, solid waste management, and waste disposal. ${ }^{48}$

\section{Systematic Analysis of the Legal} FrameWORK REgarding WaStewater

A systematic, step-by-step analysis of the legal framework concerning wastewater can assist interested parties in navigating the complex regulatory scheme and managing the information relevant to their roles. We present such an analysis in the following sections.

43 Instituto Nacional de Estadística, Geografía e Informática [INEG], Panorama Sociodemográfico de Baja California Sur, 16 (2015), available at http://ceieg.bcs.gob.mx/wocontent/uploads/2016/08/702825082109.pdf.

44 Id.

45 Jobst Wurl \& Felipe García, Plan Estatal de Acción Cuimática en BCS, Recursos Hídricos 42 (UABCS, 2012).

$46 I d$.

47 Z. M. Tejas Álvarez, Aguas residuales no residenciales en la Ciudad de La Paz: Cumplimiento o incumplimiento con la normatividad ambiental (2013) (unpublished master's thesis in environmental and natural resource economics, Universidad Autónoma de Baja California Sur).

48 Comisión Nacional del Agua [CONAGUA], supra note 35. 


\section{Constitutional Analysis}

The legal framework regarding water in Mexico is grounded in the principle that water is a resource which, by virtue of its strategic importance, is considered to be a matter of national security. As a result, water is regulated in the first instance by Articles 4, 27, 73, 115, and 124 of the Mexican Constitution (CPEUM), which establish the fundamental principles on which all other applicable legislation and public policy must be based. ${ }^{49}$

Our analysis begins with the sixth paragraph of Article 4, which establishes the right to a healthy environment for human well-being and development; the right to health; the right to clean, potable water; and the right to adequate sanitation services. The other referenced articles define and establish the foundations for the nation's sustainable development and the division of jurisdiction over the nation's water resources, and empower the federal government to safeguard the rights enshrined in Article 4. The table below lists the relevant constitutional articles and highlights the principle embodied in each, more specifically, identifying the articles designed to regulate rights, and the articles that establish the wastewater-related powers of the federal, state and municipal authorities. ${ }^{50}$

\section{Table I. Relevant Articles of the Mexican Constitution}

\begin{tabular}{|c|l|}
\hline Article & \multicolumn{1}{c|}{ Relevance } \\
\hline \multirow{4}{*}{$\begin{array}{c}\text { p, sixth } \\
\text { paragraph }\end{array}$} & $\begin{array}{l}\text { Establishes the human right to water: Everyone has the right of access to, } \\
\text { disposal of, and treatment of sufficient quantities of clean water for per- } \\
\text { sonal and domestic consumption, in an acceptable form and at an afford- } \\
\text { able cost. The State shall guarantee this right and the law shall establish } \\
\text { the bases, assistance, and modalities for equitable and sustainable access to, } \\
\text { and use of, water resources, establishing the participation of the Federa- } \\
\text { tion, the federative entities [states], and the municipalities, as well as the } \\
\text { participation of the citizenry, in the achievement of these ends. }\end{array}$ \\
\hline 27 & $\begin{array}{l}\text { Provides that water is the property of the nation and grants power to } \\
\text { the State for regulating its sustainable use, stewarding its conservation, } \\
\text { achieving the sustainable development of the country, and improving the } \\
\text { living conditions of the population. Emphasizes that the participation of } \\
\text { both the citizenry and the three levels of government is indispensable. } \\
\text { Specifies that the nation's dominion is inalienable and imprescriptible, } \\
\text { and that the exploitation, use, and enjoyment of water shall take place } \\
\text { exclusively by means of concessions granted by the Executive Branch as } \\
\text { prescribed by law. }\end{array}$ \\
\hline
\end{tabular}

49 Constitución Política de los Estados Unidos Mexicanos [Const.], supra note 24.

50 Carmona Lara supra note 13 at 28-29. 
Esta revista forma parte del acervo de la Biblioteca Jurídica Virtual del Instituto de Investigaciones Jurídicas de la UNAM

\begin{tabular}{|c|l|}
\hline Article & \multicolumn{1}{c|}{ Relevance } \\
\hline 73 & $\begin{array}{l}\text { Establishes the power of the federal Congress to enact laws concerning } \\
\text { the use and exploitation of waters under federal jurisdiction, establish } \\
\text { compensatory payments for its exploitation and use, and enact laws har- } \\
\text { monizing the legislation of the federal, state, and municipal levels of gov- } \\
\text { ernment, within the scope of their respective jurisdictions, as it relates to } \\
\text { environmental protection and the preservation and restoration of ecologi- } \\
\text { cal equilibrium. }\end{array}$ \\
\hline 115 & $\begin{array}{l}\text { Specifies that the municipalities will have responsibility over the supply } \\
\text { of water to their residents, as well as drainage, sewage, treatment, and } \\
\text { disposal services for the wastewater they produce. }\end{array}$ \\
\hline 124 & $\begin{array}{l}\text { Provides that powers not expressly granted by the Mexican Constitution } \\
\text { to the Federation are reserved to the states. }\end{array}$ \\
\hline
\end{tabular}

SOURCE: The authors, based on the CPEUM.

\section{Analysis of the Spheres of Validity}

This step of the analysis will focus on the particular provisions relevant to our evaluation of the legal framework regarding wastewater in Baja California Sur, with reference to the four spheres of validity. This approach could be considered a static vision of the law, since it precisely delineates the extent to which the law applies. ${ }^{51}$ The four spheres of validity are:

1) Spatial sphere. This sphere refers to the the validity of the applicable provisions based on the geographical space to which the law applies; it may be territorial, extraterritorial, federal, state, or municipal. In the case under examination here, the relevant provisions are the federal laws, BCS state laws, and the bylaws adopted by each of the five municipalities comprising BCS (Mulegé, Loreto, Comondú, La Paz, and Los Cabos).

2) Temporal sphere. This sphere refers to the validity of the applicable provisions with reference to time, taking into account the dates on which each law took effect, as well as any subsequent reforms or amendments that supersede or rescind a prior provision. In this study, we have analyzed the most recent texts of all wastewater-related laws currently in force.

3) Material sphere. This sphere refers to the legal regime applicable to a given natural resource, understood to be any of the natural elements subject to use under Article 27 of the Constitution. ${ }^{52}$ In the present case, we will focus specifically on water law.

4) Personal sphere. This sphere refers to the specific individuals or entities who are subject to the law, that is, the natural or legal persons or other entities who acquire rights and obligations, or powers and duties, as a result of a provision. ${ }^{53}$ In the case at hand, the subjects in question are

\footnotetext{
51 Id. at 30.

52 Id. at 32.

53 Id. at 33.
} 
all natural or legal persons to whom the law applies, including social organizations, nongovernmental organizations, and wastewater-related public entities. Identifying which specific authorities have jurisdiction over wastewater management is crucial to the analysis of the legal system and its effectiveness. Table II lists all the competent authorities at the federal, state and municipal levels.

\section{Table II. Public Entities Connected to Wastewater Regulation}

\begin{tabular}{|c|c|}
\hline Level & Entity \\
\hline \multirow{7}{*}{ Federal } & $\begin{array}{l}\text { SEMARNAT. Secretaría de Medio Ambiente y Recursos Naturales (Secre- } \\
\text { tary of the Environment and Natural Resources). }\end{array}$ \\
\hline & CONAGUA. Comisión Nacional del Agua (National Commission on Water). \\
\hline & $\begin{array}{l}\text { IMTA. Instituto Mexicano de Tecnología del Agua (Mexican Institute of Wa- } \\
\text { ter Technology). }\end{array}$ \\
\hline & $\begin{array}{l}\text { PROFEPA. Procuraduría Federal de Protección al Ambiente (Attorney Gen- } \\
\text { eral for Environmental Protection). }\end{array}$ \\
\hline & Consejos de Cuenca (Watershed Councils). \\
\hline & Secretaría de Salud (Secretary of Health). \\
\hline & $\begin{array}{l}\text { PGR. Procuraduría General de la República (Attorney General of the Re- } \\
\text { public). }\end{array}$ \\
\hline \multirow{4}{*}{ State } & $\begin{array}{l}\text { Secretaría de Desarrollo Económico, Medio Ambiente y Recursos Naturales } \\
\text { (Secretary of Economic Development, the Environment, and Natural Re- } \\
\text { sources). }\end{array}$ \\
\hline & $\begin{array}{l}\text { Subsecretaría de Medio Ambiente y Recursos Naturales (Environment and } \\
\text { Natural Resources Undersecretary). }\end{array}$ \\
\hline & CEA. Comisión Estatal del Agua (State Water Commission). \\
\hline & Baja California Sur Watershed Council. \\
\hline \multirow{5}{*}{ Municipal } & $\begin{array}{l}\text { OOMSAPA. Organismo Operador Municipal del Sistema de Agua Potable, } \\
\text { Alcantarillado y Saneamiento del Municipio de La Paz (La Paz Municipal } \\
\text { Water and Sewer Commission). }\end{array}$ \\
\hline & $\begin{array}{l}\text { OOMSAPA. Organismo Operador Municipal del Sistema de Agua Potable y } \\
\text { Alcantarillado del Municipio de Los Cabos (Los Cabos Municipal Water and } \\
\text { Sewer Commission). }\end{array}$ \\
\hline & $\begin{array}{l}\text { OOMSAPA. Organismo Operador Municipal del Sistema de Agua Potable y } \\
\text { Alcantarillado del Municipio de Comondú (Comondú Municipal Water and } \\
\text { Sewer Commission). }\end{array}$ \\
\hline & $\begin{array}{l}\text { OOMSAPA. Organismo Operador Municipal del Sistema de Agua Potable y } \\
\text { Alcantarillado del Municipio de Loreto (Loreto Municipal Water and Sewer } \\
\text { Commission). }\end{array}$ \\
\hline & $\begin{array}{l}\text { OOMSAPA. Organismo Operador Municipal del Sistema de Agua Potable y } \\
\text { Alcantarillado del Municipio de Mulegé (Mulegé Municipal Water and Sewer } \\
\text { Commission). }\end{array}$ \\
\hline
\end{tabular}

SOURCE: Authors. 
Esta revista forma parte del acervo de la Biblioteca Jurídica Virtual del Instituto de Investigaciones Jurídicas de la UNAM

\section{Hierarchization of Sources}

Legal systems are characterized by a hierarchy in which certain laws prevail over others. In Mexico, the Constitution is considered the primary law. That document emanates from the sovereign power (the People) via the Constitutional Assembly that promulgated it, and no provision shall take precedence over or contradict it. ${ }^{54}$ Article 133 establishes that the Constitution, the federal laws ensuing from it (including the National Waters Act), and international treaties, constitute the first level of the legal hierarchy. The second level is comprised of state laws enacted by state congresses, and the third level consists of municipal legal provisions.

International treaties have special relevance to environmental matters because they establish general guiding principles, such as the "precautionary principle" and the "polluter-pays" principle, which have been incorporated into both federal and state laws. Where water is concerned, various international agreements have served as a foundational framework for advancing the rights enshrined in Article 4 of the Constitution. The universal recognition of the human right to water and sanitation and the international community "calling upon Member States to adopt policies to increase access to sanitation and to ensure that water resources are protected from pollution" have had a global impact on wastewater policy. ${ }^{55}$

\section{TAble III. International Water-Related Agreements and Provisions}

\begin{tabular}{|c|l|l|}
\hline \multicolumn{3}{|c|}{ International } \\
\hline Provision & \multicolumn{1}{|c|}{ Objective } & \multicolumn{1}{c|}{ Relevance } \\
\hline $\begin{array}{c}\text { United Nations Conference } \\
\text { on Water, Mar de la Plata } \\
\text { (March 1977) } \\
\text { (not available in electronic } \\
\text { form) }\end{array}$ & $\begin{array}{l}\text { Declares that "all peoples, } \\
\text { whatever their stage of devel- } \\
\text { opment and social and eco- } \\
\text { nomic conditions, have the } \\
\text { right to have access to drink- } \\
\text { ing water in quantities and of } \\
\text { a quality equal to their basic } \\
\text { needs". }\end{array}$ \\
\hline $\begin{array}{c}\text { Agenda 21 } \\
\text { United Nations Conference } \\
\text { on Environment and } \\
\text { Development, or "Rio }\end{array}$ & $\begin{array}{l}\text { Chapter 18: Protection of the } \\
\text { Quality and Supply of Fresh- } \\
\text { water Resources: Application } \\
\text { of Integrated Approaches to }\end{array}$ & $\begin{array}{l}\text { Recognizes that all people } \\
\text { have the right to drinking wa- } \\
\text { ter, which was designated a }\end{array}$ \\
\hline
\end{tabular}

54 G. Teutli Otero, El artículo 133 y la jerarquía jurídica en México, in Guadernos de Trabajo. Seminario de Derecho Internaciona 33 (UNAM-IIJ, 2015), available at http://biblio.juridicas. unam.mx/libros/libros/libro.htm? $\mathrm{l}=4056$.

55 World Water Assessment Programme, supra note 3, at 46. 
Esta revista forma parte del acervo de la Biblioteca Jurídica Virtual del Instituto de Investigaciones Jurídicas de la UNAM

\begin{tabular}{|c|c|c|}
\hline \multicolumn{3}{|c|}{ International } \\
\hline Provision & Objective & Relevance \\
\hline $\begin{array}{l}\text { Summit", Rio de Janeiro } \\
\text { (June 1992) } \\
\text { https://sustainabledevelopment. } \\
\text { un.org/content/documents/ } \\
\text { Agenda21.pdf }\end{array}$ & $\begin{array}{l}\text { the Development, Manage- } \\
\text { ment and Use of Water Re- } \\
\text { sources. }\end{array}$ & \\
\hline $\begin{array}{c}\text { Dublin Statement on Water } \\
\text { and Sustainable } \\
\text { Development, International } \\
\text { Conference on Water and } \\
\text { Environment (ICWE), } \\
\text { Dublin (26-31 January 1992) } \\
\text { http://wwww.wmo.int/pages/ } \\
\text { prog/hwrp/documents/english/ } \\
\text { icwedece.html }\end{array}$ & $\begin{array}{l}\text { Principle } 4 \text { states: "It is vital to } \\
\text { recognize first the basic right } \\
\text { of all human beings to have } \\
\text { access to clean water and san- } \\
\text { itation at an affordable price". }\end{array}$ & $\begin{array}{l}\text { By virtue of this principle, } \\
\text { water is considered to have an } \\
\text { economic value and should } \\
\text { be recognized as an economic } \\
\text { good; the wasteful or environ- } \\
\text { mentally damaging use of this } \\
\text { resource should be avoided. }\end{array}$ \\
\hline $\begin{array}{c}\text { Fifth International } \\
\text { Conference on Population } \\
\text { and Development, New } \\
\text { York (30 June-2 July 1999) } \\
\text { https://werere.un.org/en/develop } \\
\text { ment/devagenda/population.shtml } \\
\text { wrew.un.org/popin/icpd2.htm }\end{array}$ & $\begin{array}{l}\text { Affirms that all individuals } \\
\text { have "the right to an ad- } \\
\text { equate standard of living for } \\
\text { themselves and their fami- } \\
\text { lies, including adequate food, } \\
\text { clothing, housing, water, and } \\
\text { sanitation". }\end{array}$ & $\begin{array}{l}\text { Acknowledges water and san- } \\
\text { itation as essential prerequi- } \\
\text { sites for achieving sustainable } \\
\text { global development. }\end{array}$ \\
\hline $\begin{array}{l}\text { World Summit on } \\
\text { Sustainable Development, } \\
\text { Johannesburg } \\
\text { (September 2002) } \\
\text { http://wrwre.un.org/spanish/ } \\
\text { conferences/wssd/basicinfo.html }\end{array}$ & $\begin{array}{l}\text { Establishes that supplies of } \\
\text { clean, potable water and ad- } \\
\text { equate sanitation services are } \\
\text { necessary for the protection } \\
\text { of human health and the en- } \\
\text { vironment. }\end{array}$ & $\begin{array}{l}\text { Focuses attention on human } \\
\text { dignity and the importance } \\
\text { of increasing access to basic } \\
\text { services such as drinking wa- } \\
\text { ter, sanitation, adequate hous- } \\
\text { ing, energy, healthcare, food } \\
\text { security, and the protection of } \\
\text { biodiversity. }\end{array}$ \\
\hline $\begin{array}{l}\text { General Comment No. } \\
15 \text { of the United Nations } \\
\text { Economic and Social } \\
\text { Council on the Right to } \\
\text { Water (November 2002) } \\
\text { https://wrew2.ohchrorg/eng } \\
\text { lish/issues/water/docs/CES } \\
\text { CR_GC_15.pdf }\end{array}$ & $\begin{array}{l}\text { Paragraph } 1 \text { reads: "The hu- } \\
\text { man right to water is indis- } \\
\text { pensable for leading a life in } \\
\text { human dignity. It is a prereq- } \\
\text { uisite for the realization of } \\
\text { other human rights". }\end{array}$ & $\begin{array}{l}\text { Reaffirms the right to water } \\
\text { in international law. }\end{array}$ \\
\hline $\begin{array}{c}\text { United Nations General } \\
\text { Assembly Resolution A/ } \\
\text { RES/64/292 (July 2010) } \\
\text { wrwre.ohchr.org/EN/Issues/ } \\
\text { WaterAndSanitation/SRWater/ } \\
\text { Pages/Resolutions.aspx }\end{array}$ & $\begin{array}{l}\text { Officially recognizes access to } \\
\text { clean, safe drinking water and } \\
\text { sanitation as human rights es- } \\
\text { sential for the full realization } \\
\text { of all other human rights. }\end{array}$ & $\begin{array}{l}\text { The Resolution "calls upon } \\
\text { States and international orga- } \\
\text { nizations to provide financial } \\
\text { resources, capacity-building } \\
\text { and technology transfer, thro- } \\
\text { ugh international assistance } \\
\text { and cooperation, in particu- } \\
\text { lar to developing countries, in }\end{array}$ \\
\hline
\end{tabular}


Esta revista forma parte del acervo de la Biblioteca Jurídica Virtual del Instituto de Investigaciones Jurídicas de la UNAM

\begin{tabular}{|l|l|l|}
\hline \multicolumn{2}{|c|}{ International } \\
\hline Provision & Objective & \multicolumn{1}{c|}{ Relevance } \\
\hline & & $\begin{array}{l}\text { order to scale up efforts to } \\
\text { provide safe, clean, accessible } \\
\text { and affordable drinking wa- } \\
\text { ter and sanitation for all”. }\end{array}$ \\
\hline
\end{tabular}

SOURCE: Authors.

As the above table shows, from its first formal recognition in 1977, the right of access to drinking water has been continually strengthened, to the point that it is now considered to be a fundamental human right and indispensable for living in dignity. It is reinforced by the acknowledgement of the right to sanitation, both of which are prior conditions for the realization of other human rights, and are imperative for the achievement of sustainable development. These international law principles were incorporated into Mexico's legal framework by the addition of the sixth paragraph to Article 4 of the Constitution, published in the Official Gazette of the Federation (Diario Oficial de la Federación [DOF]) on 8 February 2012. Subsequently, the entire secondary legal framework for water - the National Waters Act first and foremost - was harmonized to conform with the Constitution.

The secondary legislation applicable to water administration regulates a wide variety of matters that are under the jurisdiction of different authorities. It is extensive and complex. Each of these laws establishes rights and obligations relating to individuals as well as the competent governmental authorities, and each mandate must be put into effect by the promulgation of appropriate provisions and policies. The wastewater management regime is primarily governed by provisions concerning permits and licenses, wastewater quality standards, and zoning. Other provisions address water collection, treatment, and reuse for specific purposes. In addition to these are regulations concerning urban utilities, which include utilities responsible for the supply of drinking water and wastewater management. ${ }^{56}$ The following tables present our analysis of the principal legal provisions applicable to wastewater discharges in Mexico.

Table IV. Federal Legal Provisions

APPlicable to Wastewater

\begin{tabular}{|c|c|c|}
\hline \multicolumn{3}{|c|}{ Federal } \\
\hline Law & Objective & Relevance \\
\hline $\begin{array}{c}\text { Constitución Política } \\
\text { de los Estados Unidos } \\
\text { Mexicanos (Mexican } \\
\text { Constitution), Articles 4, 27, }\end{array}$ & $\begin{array}{l}\text { The foundational document } \\
\text { establishing the rights and du- } \\
\text { ties of the Mexican people, the } \\
\text { powers of the Federation (le- }\end{array}$ & $\begin{array}{l}\text { Establishes the human right } \\
\text { of access to, disposal of, and } \\
\text { treatment of sufficient quan- } \\
\text { tities of clean water for per- }\end{array}$ \\
\hline
\end{tabular}

56 Id. at 50 . 
Esta revista forma parte del acervo de la Biblioteca Jurídica Virtual del Instituto de Investigaciones Jurídicas de la UNAM

\begin{tabular}{|c|c|c|}
\hline \multicolumn{3}{|c|}{ Federal } \\
\hline Law & Objective & Relevance \\
\hline $\begin{array}{c}\text { 73, } 115 \text {, and } 124 . \\
\text { DOF, } 5 \text { February } 1917 \text {; } \\
\text { latest revision, DOF, } 15 \\
\text { September } 2017 \\
\text { http://rerere.diputados.gob.mx/ } \\
\text { LeyesBiblio/index.htm }\end{array}$ & $\begin{array}{l}\text { gislative, executive, and judi- } \\
\text { cial branches), and the three } \\
\text { levels of government (federal, } \\
\text { state, and municipal). Defines } \\
\text { the structure of the govern- } \\
\text { ment and the organization of } \\
\text { its institutions. }\end{array}$ & $\begin{array}{l}\text { sonal and domestic consump- } \\
\text { tion, in an acceptable form } \\
\text { and at an affordable cost. } \\
\text { Establishes the State's obliga- } \\
\text { tion to guarantee this right, } \\
\text { as well as the right of access } \\
\text { to, and equitable and sustain- } \\
\text { able use of, water resources. } \\
\text { Establishes the necessity of } \\
\text { the participation of the Fed- } \\
\text { eration, the states, the mu- } \\
\text { nicipalities, and the public in } \\
\text { achieving these ends. } \\
\text { Establishes the water prop- } \\
\text { erty regime and the division } \\
\text { of jurisdiction with respect to } \\
\text { wastewater management. }\end{array}$ \\
\hline $\begin{array}{c}\text { Ley General del Equilibrio } \\
\text { Ecológico y la Protección } \\
\text { al Ambiente (Mexican } \\
\text { Environmental Protection } \\
\text { Act) DOF, 28 January 1988; } \\
\text { latest revision, DOF } 19 \\
\text { January } 2018 \\
\text { http://wrere.diputados.gob.mx/ } \\
\text { LeyesBiblio/index.htm }\end{array}$ & $\begin{array}{l}\text { Law enacted in furtherance } \\
\text { of the Mexican Constitution } \\
\text { regarding environmental ma- } \\
\text { tters. Its objective is the pro- } \\
\text { motion of sustainable devel- } \\
\text { opment, and the prevention } \\
\text { and control of air, water, and } \\
\text { soil pollution. It lays the foun- } \\
\text { dation for the sustainable en- } \\
\text { joyment, preservation, and re- } \\
\text { storation of water and other } \\
\text { natural resources, so that eco- } \\
\text { nomic gains and societal ac- } \\
\text { tivities are compatible with } \\
\text { the preservation of ecosys- } \\
\text { tems. }\end{array}$ & $\begin{array}{l}\text { Establishes the criteria for the } \\
\text { prevention and control of wa- } \\
\text { ter and aquatic ecosystem po- } \\
\text { llution by the regulation of } \\
\text { wastewater discharges. } \\
\text { Establishes sanctions regard- } \\
\text { ing the pollution of water. } \\
\text { This is the Mexican federal } \\
\text { law that governs wastewater } \\
\text { discharges and clarifies the } \\
\text { division of jurisdiction set out } \\
\text { in the Constitution. }\end{array}$ \\
\hline $\begin{array}{c}\text { Ley de Aguas Nacionales } \\
\text { (National Waters Act) } \\
\text { DOF, } 1 \text { December 1992; } \\
\text { latest revision, DOF, 24 } \\
\text { March 2016 } \\
\text { http://wrerc.diputados.gob.mx/ } \\
\text { LeyesBiblio/index.htm }\end{array}$ & $\begin{array}{l}\text { Law enacted in furtherance } \\
\text { of Article } 27 \text { of the Consti- } \\
\text { tution regarding national wa- } \\
\text { ters; its goal is to regulate the } \\
\text { exploitation, use, and enjoy- } \\
\text { ment of these waters, their dis- } \\
\text { tribution and control, as well } \\
\text { as the preservation of their } \\
\text { quality and quantity with a } \\
\text { view to achieving compre- } \\
\text { hensive sustainable develop- } \\
\text { ment. }\end{array}$ & $\begin{array}{l}\text { Provides the framework for } \\
\text { laws concerning national wa- } \\
\text { ters, including wastewater re- } \\
\text { gulation. Governs wastewa- } \\
\text { ter quality, the prevention and } \\
\text { control of wastewater conta- } \\
\text { mination, wastewater recircu- } \\
\text { lation and reuse, and the con- } \\
\text { struction and operation of } \\
\text { facilities for the prevention, } \\
\text { control, and mitigation of wa- } \\
\text { ter pollution, including was- } \\
\text { tewater treatment plants. }\end{array}$ \\
\hline
\end{tabular}


Esta revista forma parte del acervo de la Biblioteca Jurídica Virtual del Instituto de Investigaciones Jurídicas de la UNAM

\begin{tabular}{|c|c|c|}
\hline \multicolumn{3}{|c|}{ Federal } \\
\hline Law & Objective & Relevance \\
\hline & & $\begin{array}{l}\text { In addition, it specifically es- } \\
\text { tablishes the division of juris- } \\
\text { diction among the competent } \\
\text { authorities. }\end{array}$ \\
\hline $\begin{array}{l}\text { Ley Federal de Derechos } \\
\text { (Federal Duties Act) } \\
\text { DOF, } 31 \text { December 1981; } \\
\text { latest revision, DOF, } 7 \\
\text { December 2016 } \\
\text { http://wrerr.diputados.gob.mx/ } \\
\text { LeyesBiblio/index.htm }\end{array}$ & $\begin{array}{l}\text { Establishes the fees payable } \\
\text { for the use or enjoyment of } \\
\text { property in the public domain } \\
\text { as well as for the receipt of } \\
\text { services provided by the State } \\
\text { in its public law capacity. } \\
\text { Classifies the zones of water } \\
\text { availability and the publicly } \\
\text { owned receiving entities for } \\
\text { wastewater discharges, and } \\
\text { determines the fees for their } \\
\text { use, as well as the fees appli- } \\
\text { cable to wastewater dischar- } \\
\text { ges as a function of their qua- } \\
\text { lity and the nature of the re- } \\
\text { ceiving entities. }\end{array}$ & $\begin{array}{l}\text { Establishes the obligation to } \\
\text { pay fees for the use or enjoy- } \\
\text { ment of national property in } \\
\text { the public domain, such as } \\
\text { entities receiving wastewater } \\
\text { discharges; for discharging } \\
\text { wastewater on an ongoing, } \\
\text { intermittent, or accidental ba- } \\
\text { sis into rivers, watersheds, ri- } \\
\text { ver or stream beds, lagoons, } \\
\text { ponds, marine waters, or other } \\
\text { bodies of water or watercour- } \\
\text { ses; for discharging wastewa- } \\
\text { ter into soils or causing it to } \\
\text { infiltrate into land that is na- } \\
\text { tional property, or where such } \\
\text { discharges could contaminate } \\
\text { the subsoil or aquifers, as pre- } \\
\text { scribed by this Act. }\end{array}$ \\
\hline $\begin{array}{c}\text { Ley General de } \\
\text { Asentamientos Humanos, } \\
\text { Ordenamiento Territorial } \\
\text { y Desarrollo Urbano } \\
\text { (Mexican Settlement, } \\
\text { Zoning, and Urban } \\
\text { Development Act) } \\
\text { DOF, } 28 \text { November } 2016 \\
\text { http://rererc.diputados.gob.mx/ } \\
\text { LeyesBiblio/index.htm }\end{array}$ & $\begin{array}{l}\text { Establishes basic standards } \\
\text { and compulsory management } \\
\text { mechanisms for the planning } \\
\text { of land use and human habi- } \\
\text { tation in Mexico. }\end{array}$ & $\begin{array}{l}\text { Establishes that a comprehen- } \\
\text { sive water and water resource } \\
\text { management system, includ- } \\
\text { ing water supply, drainage, } \\
\text { sanitation, wastewater treat- } \\
\text { ment, watershed restoration, } \\
\text { and rainwater use, is a matter } \\
\text { of metropolitan interest. Pro- } \\
\text { vides that the plans and pro- } \\
\text { grams in metropolitan areas } \\
\text { or conurbations must provide } \\
\text { for and include measures to } \\
\text { improve the environmental } \\
\text { condition and comprehensive } \\
\text { management of water. }\end{array}$ \\
\hline $\begin{array}{l}\text { Ley General de Bienes } \\
\text { Nacionales (National } \\
\text { Property Act) } \\
\text { DOF, } 20 \text { May } 2004\end{array}$ & $\begin{array}{l}\text { Identifies the property cons- } \\
\text { tituting the national heritage } \\
\text { and establishes the public do- } \\
\text { main regime regarding prop- } \\
\text { erty of the Federation. }\end{array}$ & $\begin{array}{l}\text { Lists the property subject to } \\
\text { the public domain regime } \\
\text { of the Federation, significant } \\
\text { because wastewater dumped } \\
\text { onto national property falls } \\
\text { under federal jurisdiction. }\end{array}$ \\
\hline $\begin{array}{l}\text { Código Penal Federal } \\
\text { (Federal Penal Code) } \\
\text { DOF, } 14 \text { August 1931; }\end{array}$ & $\begin{array}{l}\text { This code regarding federal } \\
\text { offenses is applicable through- } \\
\text { out the Republic. }\end{array}$ & $\begin{array}{l}\text { Establishes that anyone who } \\
\text { illicitly discharges, dumps, } \\
\text { or causes the infiltration of }\end{array}$ \\
\hline
\end{tabular}


Esta revista forma parte del acervo de la Biblioteca Jurídica Virtual del Instituto de Investigaciones Jurídicas de la UNAM

\begin{tabular}{|c|c|c|}
\hline \multicolumn{3}{|c|}{ Federal } \\
\hline Law & Objective & Relevance \\
\hline $\begin{array}{c}\text { latest revision, DOF, } \\
9 \text { March } 2018 \\
\text { http://wwww.diputados.gob.mx/ } \\
\text { LeyesBiblio/ref/cpf.htm }\end{array}$ & $\begin{array}{l}\text { Title } 25 \text { covers offenses a- } \\
\text { gainst the environment as well } \\
\text { as those affecting environ- } \\
\text { mental management. }\end{array}$ & $\begin{array}{l}\text { wastewater, liquid chemicals, } \\
\text { biochemicals, wastes, or pol- } \\
\text { lutants into soils, subsoils, } \\
\text { marine waters, rivers, wa- } \\
\text { tersheds, lagoons, ponds, or } \\
\text { other bodies of water, or wa- } \\
\text { tercourses under federal ju- } \\
\text { risdiction, thus causing a risk } \\
\text { of harm or harming natural } \\
\text { resources, flora, fauna, water } \\
\text { quality, ecosystems, or the en- } \\
\text { vironment, or who so autho- } \\
\text { rizes or orders, is liable to a } \\
\text { term of } 1 \text { to } 9 \text { years of im- } \\
\text { prisonment and a fine of } 300 \\
\text { to } 3000 \text { times the daily mini- } \\
\text { mum wage. When the waste in } \\
\text { question is dumped or flows } \\
\text { into or toward a protected } \\
\text { natural area, the term of im- } \\
\text { prisonment increases by up to } \\
\text { an additional three years and } \\
\text { the fine increases by up to } \\
\text { an additional } 1000 \text { times the } \\
\text { minimum wage. }\end{array}$ \\
\hline $\begin{array}{c}\text { Ley General de Cambio } \\
\text { Climático (Mexican } \\
\text { Climate Change Act) } \\
\text { DOF, 6 June 2012; latest } \\
\text { revision, DOF 13 July } 2018 \\
\text { http://wrwrediputados. } \\
\text { gob.mx/LeyesBiblio/pdf/ } \\
\text { LGCC_130718.pdf }\end{array}$ & $\begin{array}{l}\text { Establishes the parameters } \\
\text { for confronting the adverse } \\
\text { effects of climate change. }\end{array}$ & $\begin{array}{l}\text { Sets forth the authority of } \\
\text { the municipalities to formu- } \\
\text { late and apply measures and } \\
\text { policies to confront climate } \\
\text { change in matters such as } \\
\text { providing potable water and } \\
\text { sanitation services. } \\
\text { Mentions that all three levels } \\
\text { of government should take } \\
\text { measures for climate change } \\
\text { adaptation, including, the pay- } \\
\text { ment of taxes for the use of } \\
\text { water and environmental ser- } \\
\text { vices provided by ecosystems } \\
\text { set aside for conservation. }\end{array}$ \\
\hline $\begin{array}{c}\text { Ley Federal de } \\
\text { Responsabilidad Ambiental } \\
\text { (Federal Environmental } \\
\text { Responsability Act) } \\
\text { DOF, 7 June } 2013 \\
\text { http://wrere.diputados.gob.mx/ } \\
\text { LeyesBiblio/pdf/LFRA.pdf }\end{array}$ & $\begin{array}{l}\text { Enhances Article } 4 \text { of the } \\
\text { Constitution by protecting, } \\
\text { preserving and promoting en- } \\
\text { vironmental restoration, and } \\
\text { guarantees the human rights } \\
\text { enshrined in that Article. It } \\
\text { establishes the legal proce- } \\
\text { dure for the determination of } \\
\text { environmental responsibility. }\end{array}$ & $\begin{array}{l}\text { Applicable to all actions that } \\
\text { cause environmental damage } \\
\text { and provides for the repair or } \\
\text { compensation for such da- } \\
\text { mage. }\end{array}$ \\
\hline
\end{tabular}

SOURCE: Authors. 
Esta revista forma parte del acervo de la Biblioteca Jurídica Virtual del Instituto de Investigaciones Jurídicas de la UNAM

\section{Table V. Federal Regulations \\ ApPlicable to Wastewater}

\begin{tabular}{|c|c|c|}
\hline \multicolumn{3}{|c|}{ Federal } \\
\hline Regulation & Objective & Relevance \\
\hline $\begin{array}{l}\text { Reglamento de la Ley } \\
\text { de Aguas Nacionales } \\
\text { (Regulations of the } \\
\text { National Waters Act) } \\
\text { http://rerere.diputados.gob. } \\
\text { mx/LeyesBiblio/regley/Reg } \\
\text { LAN_250814.pdf }\end{array}$ & $\begin{array}{l}\text { The are the regulations re- } \\
\text { lating to the National Waters } \\
\text { Act. }\end{array}$ & $\begin{array}{l}\text { Sets out specific and detailed } \\
\text { regulations to the provisions } \\
\text { of the Act governing waste- } \\
\text { water discharges. }\end{array}$ \\
\hline $\begin{array}{c}\text { Reglamento Interior } \\
\text { de la SEMARNAT } \\
\text { (Internal Regulation of the } \\
\text { Secretary of Environment } \\
\text { and Natural Resources) } \\
\text { DOF, } 26 \text { November } 2012 \\
\text { http://dof.gob.mx/nota_det } \\
\text { alle.php?codigo }=5366662 \text { Gfec } \\
\text { ha=31/10/2014 }\end{array}$ & $\begin{array}{l}\text { Establishes the agency's ad- } \\
\text { ministrative structure and its } \\
\text { distribution of powers. }\end{array}$ & $\begin{array}{l}\text { Sets out the powers of SE- } \\
\text { MARNAT, including PRO- } \\
\text { FEPA, in the area of waste- } \\
\text { water discharges and the } \\
\text { jurisdiction of these agencies } \\
\text { over the regulation and con- } \\
\text { trol thereof. }\end{array}$ \\
\hline $\begin{array}{c}\text { Reglamento Interior } \\
\text { de la Comisión Nacional } \\
\text { del Agua (Internal } \\
\text { Regulations of the National } \\
\text { Waters Commission) } \\
\text { DOF, } 30 \text { November } 2006 \\
\text { http://wrere.diputados.gob.mx/ } \\
\text { LeyesBiblio/regla/n28.pdf }\end{array}$ & $\begin{array}{l}\text { Establishes the administrati- } \\
\text { ve structure of CONAGUA, } \\
\text { a decentralized body of SE- } \\
\text { MARNAT, and specifies its } \\
\text { internal distribution of po- } \\
\text { wers. }\end{array}$ & $\begin{array}{l}\text { Establishes the division of ju- } \\
\text { risdiction over the regulation } \\
\text { and control of wastewater dis- } \\
\text { charges. }\end{array}$ \\
\hline $\begin{array}{c}\text { Reglamento de la LGEEPA } \\
\text { en materia de Evaluación } \\
\text { del Impacto Ambiental } \\
\text { (Environmental Impact } \\
\text { Regulations of the } \\
\text { Mexican Environmental } \\
\text { Protection Act) } \\
\text { DOF, } 30 \text { May 2000; } \\
\text { latest revision, DOF, } 31 \\
\text { October 2014 } \\
\text { http://wrore.profepa.gob.mx/ } \\
\text { innovaportal/file/1155/1/ } \\
\text { reglamento_de_la_lgeepa_en_- } \\
\text { materia_de_evaluacion_del_im } \\
\text { pacto_ambiental.pdf }\end{array}$ & $\begin{array}{l}\text { Specifies the parties requir- } \\
\text { ing prior environmental im- } \\
\text { pact approval from SEMAR- } \\
\text { NAT. }\end{array}$ & $\begin{array}{l}\text { Establishes that wastewater } \\
\text { treatment plants discharging } \\
\text { liquids or sludge into bod- } \\
\text { ies of water that constitute } \\
\text { national property must have } \\
\text { prior environmental impact } \\
\text { approval from SEMARNAT. }\end{array}$ \\
\hline
\end{tabular}

SOURCE: Authors. 
Esta revista forma parte del acervo de la Biblioteca Jurídica Virtual del Instituto de Investigaciones Jurídicas de la UNAM

\section{Table VI. Official Mexican Standards \\ Applicable to Wastewater}

\begin{tabular}{|c|c|c|}
\hline \multicolumn{3}{|c|}{ Federal } \\
\hline Standard & Objective & Relevance \\
\hline $\begin{array}{c}\text { NOM-001- } \\
\text { SEMARNAT-1996 } \\
\text { NOM-001-ECOL-1996 } \\
\text { DOF, 6 June 1997 } \\
\text { http://wrere.semarnat.gob.mx/ } \\
\text { leyes-y-normas/nom-agua }\end{array}$ & $\begin{array}{l}\text { Establishes maximum permi- } \\
\text { ssible limits on pollutants in } \\
\text { wastewater discharges into } \\
\text { national waters and property. }\end{array}$ & $\begin{array}{l}\text { Establishes the maximum per- } \\
\text { missible limits on pollutants } \\
\text { in wastewater discharges into } \\
\text { national waters and property } \\
\text { in order to protect their qual- } \\
\text { ity and make their various } \\
\text { uses possible. Compliance is } \\
\text { mandatory for persons res- } \\
\text { ponsible for such discharges. } \\
\text { This standard does not ap- } \\
\text { ply to water discharges from } \\
\text { drains separated from rain- } \\
\text { water. }\end{array}$ \\
\hline $\begin{array}{c}\text { NOM-002- } \\
\text { SEMARNAT-1996 } \\
\text { DOF, 3 June } 1998 \\
\text { http://rerere.semarnat.gob.mx/ } \\
\text { leyes-y-normas/nom-agua }\end{array}$ & $\begin{array}{l}\text { Establishes maximum permi- } \\
\text { ssible limits on pollutants in } \\
\text { wastewater discharged into } \\
\text { urban or municipal sewer sys- } \\
\text { tems. }\end{array}$ & $\begin{array}{l}\text { Establishes the maximum per- } \\
\text { missible limits on pollutants in } \\
\text { wastewater discharged into } \\
\text { urban or municipal sewer sys- } \\
\text { tems in order to prevent and } \\
\text { control the pollution of na- } \\
\text { tional waters and property } \\
\text { as well as to protect the in- } \\
\text { frastructure of such systems. } \\
\text { Compliance is compulsory for } \\
\text { persons responsible for such } \\
\text { discharges. The standard does } \\
\text { not apply to discharges of do- } \\
\text { mestic wastewater, stormwa- } \\
\text { ter, or industry-generated was- } \\
\text { tewater that is routed through } \\
\text { a separate drainage system } \\
\text { than the process wastewater. }\end{array}$ \\
\hline $\begin{array}{c}\text { NOM-003- } \\
\text { SEMARNAT-1997 } \\
\text { NOM-003-ECOL-1997 } \\
\text { DOF, 21 September } 1998 \\
\text { http://rerwresemarnat.gob.mx/ } \\
\text { leyes-y-normas/nom-agua }\end{array}$ & $\begin{array}{l}\text { Establishes maximum permis- } \\
\text { sible limits on pollutant levels } \\
\text { in treated wastewater reused } \\
\text { by public utilities. }\end{array}$ & $\begin{array}{l}\text { Designed to protect the envi- } \\
\text { ronment and public health; } \\
\text { compliance is compulsory for } \\
\text { public entities responsible } \\
\text { for wastewater treatment and } \\
\text { reuse. } \\
\text { Where the utility is under the } \\
\text { responsibility of a third party, } \\
\text { that party is responsible for } \\
\text { compliance with the standard } \\
\text { from the point of production } \\
\text { of treated water to its reuse or } \\
\text { delivery, including the piping } \\
\text { or transportation thereof. }\end{array}$ \\
\hline
\end{tabular}


Esta revista forma parte del acervo de la Biblioteca Jurídica Virtual del Instituto de Investigaciones Jurídicas de la UNAM

\begin{tabular}{|c|c|c|}
\hline \multicolumn{3}{|c|}{ Federal } \\
\hline Standard & Objective & Relevance \\
\hline $\begin{array}{c}\text { NOM-014- } \\
\text { CONAGUA-2003 } \\
\text { DOF, } 18 \text { August } 2009 \\
\text { http://wrere.semarnat.gob.mx/ } \\
\text { leyes-y-normas/nom-agua }\end{array}$ & $\begin{array}{l}\text { Establishes requirements re- } \\
\text { garding the artificial recharg- } \\
\text { ing of aquifers with treated } \\
\text { wastewater. }\end{array}$ & $\begin{array}{l}\text { Establishes requirements in } \\
\text { terms of the operation, mon- } \\
\text { itoring, and water quality of } \\
\text { artificial systems used in the } \\
\text { recharging of aquifers with } \\
\text { treated wastewater. }\end{array}$ \\
\hline
\end{tabular}

SOURCE: Authors.

\section{Table VII. Federal Environmental Policy Instruments}

\begin{tabular}{|c|c|c|}
\hline Regulation & Objective & Relevance \\
\hline $\begin{array}{c}\text { Plan Nacional de } \\
\text { Desarrollo 2019-2024 } \\
\text { (National Development } \\
\text { Plan 2019-2024) } \\
\text { DOF, 12 July 2019 } \\
\text { https://wrere.dof.gob.mx/ } \\
\text { nota_detalle.php?.codigo=55655 } \\
\text { 99Efecha=12/07/2019 }\end{array}$ & $\begin{array}{l}\text { Its goal is to transform the } \\
\text { country's public life in order } \\
\text { to achieve inclusive develop- } \\
\text { ment. }\end{array}$ & $\begin{array}{l}\text { Theme } 2 . \text { Welfare: } \\
\text { Item 2.5.8. Pollution control } \\
\text { Issue to be considered: water } \\
\text { and sanitation. }\end{array}$ \\
\hline $\begin{array}{l}\text { Programa Nacional Hídrico } \\
\text { 2019-2024 (National Water } \\
\text { Program 2019-2024) } \\
\text { (executive order) } \\
\text { https://wrwre.gob.mx/cms/up } \\
\text { loads/attachment/file/527601/ } \\
\text { Decreto_PNH_final.pdf }\end{array}$ & $\begin{array}{l}\text { Guarantees the human right } \\
\text { to water and sanitation, espe- } \\
\text { cially for the most vulnerable } \\
\text { population. } \\
\text { Water should be used effi- } \\
\text { ciently to promote sustain- } \\
\text { able development. } \\
\text { Improve water governance } \\
\text { conditions. }\end{array}$ & $\begin{array}{l}\text { Document not available for } \\
\text { review. }\end{array}$ \\
\hline
\end{tabular}

SOURCE: Authors.

\section{Table VIII. BCS State Provisions Applicable TO WASTEWATER}

\begin{tabular}{|c|c|c|}
\hline \multicolumn{3}{|c|}{ State } \\
\hline Law & Objective & Relevance \\
\hline $\begin{array}{c}\text { Constitución Política del } \\
\text { Estado de Baja California } \\
\text { Sur (BCS State Constitution) } \\
\text { Boletín Oficial del Gobierno } \\
\text { del Estado (BOGE), } 15 \\
\text { January } 1975 \text {; latest revision, } \\
\text { BOGE, } 31 \text { December } 2017 \\
\text { http://wrerw.cbcs.gob.mx/index. } \\
\text { php/cmply/1486-constitucion- } \\
\text { politica-bcs }\end{array}$ & $\begin{array}{l}\text { Establishes the rights and du- } \\
\text { ties of the state's inhabitants, } \\
\text { and defines the various pow- } \\
\text { ers of the state government } \\
\text { and the division of jurisdic- } \\
\text { tion. } \\
\text { Lays the foundation for the } \\
\text { state government to promote } \\
\text { economic and social develop- } \\
\text { ment with the assurance that }\end{array}$ & $\begin{array}{l}\text { Establishes the right of all peo- } \\
\text { ple of access to, as well as the } \\
\text { disposal and treatment of, su- } \\
\text { fficient quantities of clean wa- } \\
\text { ter for personal and domestic } \\
\text { consumption, in an accepta- } \\
\text { ble form and at an affordable } \\
\text { cost. The state government } \\
\text { guarantees this right and the } \\
\text { law must establish the bases, }\end{array}$ \\
\hline
\end{tabular}


Esta revista forma parte del acervo de la Biblioteca Jurídica Virtual del Instituto de Investigaciones Jurídicas de la UNAM

\begin{tabular}{|c|c|c|}
\hline \multicolumn{3}{|c|}{ State } \\
\hline Law & Objective & Relevance \\
\hline & $\begin{array}{l}\text { it is to be comprehensive and } \\
\text { sustainable. }\end{array}$ & $\begin{array}{l}\text { assistance, and modalities for } \\
\text { the equitable and sustainable } \\
\text { access to, and use of, water } \\
\text { resources, with the partici- } \\
\text { pation of the Federation, the } \\
\text { state government, and the mu- } \\
\text { nicipalities, as well as the citi- } \\
\text { zenry, in the achievement of } \\
\text { these ends. } \\
\text { Establishes the powers and } \\
\text { obligations of the municipal } \\
\text { councils, including those re- } \\
\text { lated to the public drinking } \\
\text { water supply, drainage, sewa- } \\
\text { ge and wastewater treatment } \\
\text { and disposal functions and } \\
\text { services. }\end{array}$ \\
\hline $\begin{array}{c}\text { Ley de Equilibrio } \\
\text { Ecológico y Protección del } \\
\text { Ambiente del Estado de } \\
\text { Baja California Sur (BCS } \\
\text { State Environmental } \\
\text { Protection Act) } \\
\text { BOGE, } 30 \text { November 1991; } \\
\text { latest revision, BOGE, } 31 \\
\text { October 2016 } \\
\text { http://wrew.cbcs.gob.mx/index. } \\
\text { php/cmply/1508-ley-proteccion- } \\
\text { ambiente-bcs }\end{array}$ & $\begin{array}{l}\text { Enacted in furtherance of the } \\
\text { BCS State Constitution re- } \\
\text { garding the preservation and } \\
\text { restoration of the ecological } \\
\text { equilibrium and the protec- } \\
\text { tion of the environment. Its } \\
\text { goal is to establish such prin- } \\
\text { ciples, standards, and activi- } \\
\text { ties, inter alia, as are necessary, } \\
\text { to determine the best methods } \\
\text { for ecosystem preservation, } \\
\text { restoration, and improvement } \\
\text { as well as the prevention and } \\
\text { control of the contamination } \\
\text { of natural resources, such as } \\
\text { the atmosphere, water, and } \\
\text { soil. }\end{array}$ & $\begin{array}{l}\text { Establishes the powers of the } \\
\text { state government in preven- } \\
\text { ting and controlling the po- } \\
\text { llution of waters under its } \\
\text { jurisdiction, promoting waste- } \\
\text { water treatment and reuse, } \\
\text { verifying compliance with the } \\
\text { technical environmental stan- } \\
\text { dards on wastewater dump- } \\
\text { ing into drainage and sew- } \\
\text { age systems, and approving } \\
\text { wastewater discharges into } \\
\text { drainage and sewage systems. } \\
\text { Chapter III covers the pre- } \\
\text { vention and control of water } \\
\text { pollution. }\end{array}$ \\
\hline $\begin{array}{c}\text { Ley de Aguas } \\
\text { de Baja California Sur } \\
\text { (BCS Waters Act) } \\
\text { BOGE, 31 July 2001; } \\
\text { latest revision, BOGE, } \\
31 \text { October } 2016 \\
\text { http://wrww.ordenjuridico.gob. } \\
\text { mx/Estatal/BAFA\%20CALI } \\
\text { FORNIA\%20SUR/Leyes/ } \\
\text { BCSLET03.pdf }\end{array}$ & $\begin{array}{l}\text { Regulates the participation } \\
\text { of the state and municipal } \\
\text { authorities, within the scope } \\
\text { of their jurisdictions, relating } \\
\text { to the operation, desalination, } \\
\text { use, and enjoyment of water, } \\
\text { the provision of public drink- } \\
\text { ing water, as well as sewer and } \\
\text { water treatment services. }\end{array}$ & $\begin{array}{l}\text { This law regulates the water } \\
\text { supply, sewer, and water treat- } \\
\text { ment systems; the State Water } \\
\text { Commission; public drinking } \\
\text { water, sewer, and water treat- } \\
\text { ment services; the organiza- } \\
\text { tion, operation, and powers of } \\
\text { the municipal and intermu- } \\
\text { nicipal water and sewer au- } \\
\text { thorities; the participation of } \\
\text { the social and private sectors } \\
\text { in the delivery of public drin- } \\
\text { king water, sewer, and water } \\
\text { treatment services; the recov- } \\
\text { ery of expenses and costs of }\end{array}$ \\
\hline
\end{tabular}


Esta revista forma parte del acervo de la Biblioteca Jurídica Virtual del Instituto de Investigaciones Jurídicas de la UNAM

\begin{tabular}{|c|c|c|}
\hline \multicolumn{3}{|c|}{ State } \\
\hline Law & Objective & Relevance \\
\hline & & $\begin{array}{l}\text { investment, operation, conser- } \\
\text { vation, and connection fees; } \\
\text { and, the maintenance of drin- } \\
\text { king water, desalination, se- } \\
\text { wer, and water treatment sys- } \\
\text { tems. }\end{array}$ \\
\hline $\begin{array}{c}\text { Ley de Derechos y Productos } \\
\text { del Estado de Baja } \\
\text { California Sur (BCS State } \\
\text { Duties and Proceeds Act) } \\
\text { BOGE, } 31 \text { December } \\
\text { 2015; latest revision, BOGE, } \\
20 \text { December } 2017 \\
\text { http://wrere.cbcs.gob.mx/index. } \\
\text { php/cmply/1501-ley-derechos- } \\
\text { productos-bcs }\end{array}$ & $\begin{array}{l}\text { Establishes fees for the use or } \\
\text { enjoyment of property in the } \\
\text { public domain, as well as for } \\
\text { the receipt of services provid- } \\
\text { ed by agencies and entities of } \\
\text { the Executive Branch in the } \\
\text { exercise of its public and pri- } \\
\text { vate law functions. }\end{array}$ & $\begin{array}{l}\text { Covers the services provided } \\
\text { by the Secretary of Tourism, } \\
\text { Economy, and Sustainability. } \\
\text { Declares under the heading } \\
\text { of "Environment and Ecolo- } \\
\text { gy" that fees in an amount of } \\
1,084.00 \text { pesos shall be incu- } \\
\text { rred and paid for the registra- } \\
\text { tion of wastewater discharge } \\
\text { rights. }\end{array}$ \\
\hline $\begin{array}{c}\text { Programa Hídrico Regional } \\
\text { Vision } 2030 \text { (Vision } 2030 \\
\text { Regional Water Plan, Water } \\
\text { Administration Region I- } \\
\text { Baja California Peninsula) } \\
\text { wrere.conagua.gob.mx }\end{array}$ & $\begin{array}{l}\text { This plan describes the objec- } \\
\text { tives, strategies, actions, and } \\
\text { specific projects correspond- } \\
\text { ing to each of the guiding } \\
\text { principles of the region's } 2030 \\
\text { Water Agenda. }\end{array}$ & $\begin{array}{l}\text { Establishes guidelines to ensu- } \\
\text { re appropriate access to qual- } \\
\text { ity drinking water, sewer, and } \\
\text { water treatment services by } \\
\text { the entire population, especia- } \\
\text { lly the most vulnerable popu- } \\
\text { lation, and to secure, sufficient } \\
\text { and timely financial resourc- } \\
\text { es for the implementation of } \\
\text { the Regional Water Plan. }\end{array}$ \\
\hline $\begin{array}{c}\text { Plan Estatal de } \\
\text { Desarrollo 2015-2021 } \\
\text { (State Development Plan } \\
\text { 2015-2021) } \\
\text { Last updated 28 March } 2016 \\
\text { http://wrere.bcs.gob.mx/gobi } \\
\text { erno/ped-2015-2021/ }\end{array}$ & $\begin{array}{l}\text { Outlines the current adminis- } \\
\text { tration's vision, mission, and } \\
\text { policy positions related to de- } \\
\text { velopment. }\end{array}$ & $\begin{array}{l}\text { Strategy IV, "Quality of Li- } \\
\text { fe", establishes sustainability } \\
\text { as one of its strategies. } \\
\text { Lines of action: alternative e- } \\
\text { nergy, water supply and ac- } \\
\text { cessibility. } \\
\text { In response to increasing wa- } \\
\text { ter demand, the government } \\
\text { will provide for the construc- } \\
\text { tion of desalination plants. } \\
\text { Proposed actions include the } \\
\text { construction of additional drai- } \\
\text { nage infrastructure and waste- } \\
\text { water treatment plants. }\end{array}$ \\
\hline $\begin{array}{c}\text { Plan Hídrico Estatal } \\
\text { 2015-2021 (State Water } \\
\text { Plan 2015-2021) } \\
\text { Last updated } \\
\text { 19 February 2020 } \\
\text { http://cea.bcs.gob.mx/wo- } \\
\text { content/uploads/2017/07/ } \\
\text { PHE-2015-2021-1.9.pdf }\end{array}$ & $\begin{array}{l}\text { The umbrella document re- } \\
\text { garding water-related public } \\
\text { policy in BCS. } \\
\text { One of its principal objectives } \\
\text { is improving and increasing } \\
\text { the levels of both water sani- } \\
\text { tation and wastewater reuse. }\end{array}$ & $\begin{array}{l}\text { Establishes the actions that } \\
\text { must be taken to increase the } \\
\text { level of water sanitation in or- } \\
\text { der to protect aquifers and } \\
\text { coasts, and to prevent waste- } \\
\text { water from being a source } \\
\text { of contamination threatening } \\
\text { human health. }\end{array}$ \\
\hline
\end{tabular}


Esta revista forma parte del acervo de la Biblioteca Jurídica Virtual del Instituto de Investigaciones Jurídicas de la UNAM

\begin{tabular}{|c|c|c|}
\hline \multicolumn{3}{|c|}{ State } \\
\hline Law & Objective & Relevance \\
\hline $\begin{array}{c}\text { Programa Estatal de } \\
\text { Ordenamiento Territorial } \\
\text { para BCS (State Land } \\
\text { Use Program) } \\
\text { http://secfin.bcs.gob.mx/fnz/wp- } \\
\text { content/themes/fnz_bcs/assets/ } \\
\text { images/transparencia/marco_pro } \\
\text { gram/programas } 2015-2021 / \\
\text { Programa\%20Estatal\%20 } \\
\text { de\%20Ordenamiento\%20Ter } \\
\text { ritorial.pdf }\end{array}$ & $\begin{array}{l}\text { To promote the social, econo- } \\
\text { mic, and environmental deve- } \\
\text { lopment of the state through } \\
\text { comprehensive and sustain- } \\
\text { able natural resource man- } \\
\text { agement and balanced land } \\
\text { use, so as to contribute to the } \\
\text { improvement of the quality of } \\
\text { life of the population. }\end{array}$ & $\begin{array}{l}\text { The Program states that un- } \\
\text { treated wastewater discharges } \\
\text { are the main source of water } \\
\text { contamination. It recognizes } \\
\text { that the existing infrastruc- } \\
\text { ture is insufficient and that, in } \\
\text { many cases, wastewater does } \\
\text { not comply with the permis- } \\
\text { sible levels set out in the Of- } \\
\text { ficial Mexican Standards. } \\
\text { To address these issues, the } \\
\text { government will build and } \\
\text { maintain wastewater treat- } \\
\text { ment plants and reuse re- } \\
\text { claimed water. }\end{array}$ \\
\hline
\end{tabular}

SOURCE: Authors.

Table IX. Municipal Provisions Applicable to Wastewater

\begin{tabular}{|c|c|c|}
\hline \multicolumn{3}{|c|}{ Municipal $^{*}$} \\
\hline Provision & Objective & Relevance \\
\hline \multicolumn{3}{|c|}{ Mulegé } \\
\hline $\begin{array}{l}\text { Ley de Hacienda para } \\
\text { el Municipio de Mulegé, } \\
\text { Baja California Sur } \\
\text { (Mulegé Taxation Act) } \\
\text { BOGE, } 5 \text { November 2001; } \\
\text { latest revision, BOGE, } 31 \\
\text { December } 2012\end{array}$ & $\begin{array}{l}\text { Establishes the taxes, fees, pro- } \\
\text { ceeds, payments, remittances, } \\
\text { and extraordinary revenues } \\
\text { for the administrative expens- } \\
\text { es of the municipality. }\end{array}$ & $\begin{array}{l}\text { Establishes penalties for was- } \\
\text { tewater discharges onto pub- } \\
\text { lic roads, except as prescribed } \\
\text { by law. Establishes the fees pa- } \\
\text { yable for the supply of water, } \\
\text { as well as for drainage, sewer, } \\
\text { and wastewater treatment and } \\
\text { disposal services. }\end{array}$ \\
\hline $\begin{array}{c}\text { Plan de Desarrollo } \\
\text { Municipal 2018-2021 } \\
\text { (Municipal Development } \\
\text { Plan 2018-2021) } \\
\text { http://wwre.mulege.gob.mx/ } \\
\text { informacion-general.html }\end{array}$ & $\begin{array}{l}\text { Defines the purposes and stra- } \\
\text { tegies for the municipal gov- } \\
\text { ernment to promote develop- } \\
\text { ment, taking advantage of its } \\
\text { natural, historical and tour- } \\
\text { istic resources; identifies the } \\
\text { needs of the population as an } \\
\text { important consideration for } \\
\text { purposes of proper planning. }\end{array}$ & $\begin{array}{l}\text { Identifies wastewater as an is- } \\
\text { sue for the municipality and } \\
\text { specifies various lines of action } \\
\text { for the immediate term, in- } \\
\text { cluding commissioning a was- } \\
\text { tewater treatment plant in the } \\
\text { town of Guerrero Negro. }\end{array}$ \\
\hline \multicolumn{3}{|c|}{ Comondú } \\
\hline $\begin{array}{l}\text { Ley de Hacienda para el } \\
\text { Municipio de Comondú del } \\
\text { Estado de Baja California } \\
\text { Sur (Comondú Taxation Act) } \\
\text { BOGE, } 5 \text { November 2001; } \\
\text { latest revision, BOGE, } 31 \\
\text { December } 2012\end{array}$ & $\begin{array}{l}\text { Establishes the taxes and fees } \\
\text { payable for the provision of } \\
\text { services. }\end{array}$ & $\begin{array}{l}\text { Establishes the fees payable for } \\
\text { the supply of water, as well as } \\
\text { sewage and water treatment } \\
\text { services. }\end{array}$ \\
\hline
\end{tabular}


Esta revista forma parte del acervo de la Biblioteca Jurídica Virtual del Instituto de Investigaciones Jurídicas de la UNAM

\begin{tabular}{|c|c|c|}
\hline \multicolumn{3}{|c|}{ Municipal } \\
\hline Provision & Objective & Relevance \\
\hline $\begin{array}{l}\text { Reglamento de Agua } \\
\text { Potable, Alcantarillado } \\
\text { y Saneamiento para el } \\
\text { Municipio de Comondú } \\
\text { (Comondú Water and } \\
\text { Sewer Bylaws) } \\
\text { BOGE, } 30 \text { November } 2002\end{array}$ & $\begin{array}{l}\text { Regulates the provision of the } \\
\text { supply of water, as well as se- } \\
\text { wage and water treatment ser- } \\
\text { vices. }\end{array}$ & $\begin{array}{l}\text { The municipality may provide } \\
\text { public utility services through } \\
\text { the Comondú Water and Se- } \\
\text { wer Authority, which is res- } \\
\text { ponsible for the treatment of } \\
\text { wastewater generated by any } \\
\text { systems under its responsibi- } \\
\text { lity prior to the discharge the- } \\
\text { reof into nationally owned bo- } \\
\text { dies of water. } \\
\text { Establishes the powers of the } \\
\text { Water and Sewer Authority. }\end{array}$ \\
\hline $\begin{array}{l}\text { Reglamento de Ecología } \\
\text { y Medio Ambiente del } \\
\text { Municipio de Comondú } \\
\text { (Bylaws on Ecology and } \\
\text { the Environment for the } \\
\text { Municipality of Comondú) } \\
\text { BOGE, } 31 \text { August } 2019\end{array}$ & $\begin{array}{l}\text { Regulates the preservation, } \\
\text { restoration and conservation } \\
\text { of ecological stability, as well } \\
\text { as the protection of the envi- } \\
\text { ronment. }\end{array}$ & $\begin{array}{l}\text { Establishes provisions relating } \\
\text { to the prevention and control } \\
\text { of water pollution generated } \\
\text { by waters discharged into drai- } \\
\text { nage and sewage systems, or } \\
\text { into the open air, by commer- } \\
\text { cial or service activities within } \\
\text { the municipal territory or on } \\
\text { national waters placed under } \\
\text { municipal responsibility. } \\
\text { Covers the issuance of was- } \\
\text { tewater discharge approvals } \\
\text { and the monitoring of com- } \\
\text { pliance. }\end{array}$ \\
\hline \multicolumn{3}{|c|}{ Loreto } \\
\hline $\begin{array}{l}\text { Ley de Hacienda para el } \\
\text { Municipio de Loreto } \\
\text { (Loreto Taxation Act) } \\
\text { BOGE, } 5 \text { November } 2001 \\
\text { Latest revision, 20 } \\
\text { December 2017 }\end{array}$ & $\begin{array}{l}\text { Governs matters relating to } \\
\text { revenues constituting the Mu- } \\
\text { nicipal Public Treasury. }\end{array}$ & $\begin{array}{l}\text { The owners or holders of land } \\
\text { shall be obligated to pay the } \\
\text { cooperation fees established } \\
\text { for wastewater treatment and } \\
\text { disposal. }\end{array}$ \\
\hline $\begin{array}{c}\text { Reglamento para la } \\
\text { Protección al Ambiente } \\
\text { y la Preservación Ecológica } \\
\text { para el Municipio de } \\
\text { Loreto, Baja California } \\
\text { Sur (Loreto Environmental } \\
\text { Protection Bylaws) } \\
\text { BOGE, } 31 \text { December } 2000\end{array}$ & $\begin{array}{l}\text { Establishes principles, stan- } \\
\text { dards and measures to ensure } \\
\text { the preservation, protection, } \\
\text { improvement, establishment } \\
\text { and restoration of the envi- } \\
\text { ronment, as well as its sustai- } \\
\text { nable development; seeks the } \\
\text { preservation, control, and mi- } \\
\text { tigation of pollutants and their } \\
\text { causes for the purpose of a- } \\
\text { voiding environmental impact } \\
\text { and deterioration. }\end{array}$ & $\begin{array}{l}\text { Chapter XIII covers the pro- } \\
\text { tection and reasonable use of } \\
\text { water. } \\
\text { Establishes the power of the } \\
\text { municipal council to moni- } \\
\text { tor and control the water pol- } \\
\text { lution generated by munici- } \\
\text { pal public utilities, to require } \\
\text { those who discharge or seek } \\
\text { to discharge wastewater into } \\
\text { drainage and sewer systems } \\
\text { to refrain from exceeding the } \\
\text { maximum permissible levels, } \\
\text { and to verify that they possess } \\
\text { an installed treatment system. }\end{array}$ \\
\hline
\end{tabular}


Esta revista forma parte del acervo de la Biblioteca Jurídica Virtual del Instituto de Investigaciones Jurídicas de la UNAM

\begin{tabular}{|c|c|c|}
\hline \multicolumn{3}{|c|}{ Municipal } \\
\hline Provision & Objective & Relevance \\
\hline $\begin{array}{c}\text { Reglamento Interno del } \\
\text { Organismo Operador del } \\
\text { Sistema de Agua Potable, } \\
\text { Drenaje, Alcantarillado, } \\
\text { Tratamiento y Disposición } \\
\text { de Aguas Residuales del } \\
\text { Municipio de Loreto, Baja } \\
\text { California Sur (Internal } \\
\text { Regulations of the Loreto } \\
\text { Water and Sewer Authority) } \\
\text { BOGE, } 20 \text { March } 2000\end{array}$ & $\begin{array}{l}\text { Establishes the various pow- } \\
\text { ers and responsibilities of the } \\
\text { Loreto Water and Sewer Au- } \\
\text { thority. }\end{array}$ & $\begin{array}{l}\text { Establishes the powers of the } \\
\text { Water and Sewer Authority. }\end{array}$ \\
\hline $\begin{array}{c}\text { Programa de Ordenamiento } \\
\text { Ecológico Local (Local } \\
\text { Environmental Zoning } \\
\text { Plan) Proyecto } 2013 \\
\text { http://loreto.gob.mx/PDFs/ } \\
\text { gobierno/programa_de_orde } \\
\text { namiento_ecologico_local.pdf }\end{array}$ & $\begin{array}{l}\text { Establishes the activities that } \\
\text { may be carried out within } \\
\text { each specific zone as a func- } \\
\text { tion of their suitability for } \\
\text { that zone, with reference to } \\
\text { the various interested parties. }\end{array}$ & $\begin{array}{l}\text { Provides for optimal wastewa- } \\
\text { ter management during prep- } \\
\text { aration, construction and ope- } \\
\text { ration as a requirement for the } \\
\text { granting of project permits. } \\
\text { Provides that the municipal } \\
\text { council is responsible for the } \\
\text { treatment of residential was- } \\
\text { tewater, while the developers } \\
\text { of residential, touristic and } \\
\text { real estate projects are res- } \\
\text { ponsible for treating the was- } \\
\text { tewater generated by their } \\
\text { projects or activities. }\end{array}$ \\
\hline $\begin{array}{c}\text { Plan Municipal de } \\
\text { Desarrollo de Loreto } \\
\text { 2018-2021 (Loreto } \\
\text { Municipal Development } \\
\text { Plan 2018-2021) } \\
\text { https://ayuntamiento.loretozac. } \\
\text { mx/index.php/plan-de-desarrol- } \\
\text { lo-municipal-loreto/ }\end{array}$ & $\begin{array}{l}\text { Outlines the overall policy } \\
\text { of the municipal government } \\
\text { and lays the groundwork for } \\
\text { the government's vision of the } \\
\text { future, providing the necessa- } \\
\text { ry procedural mechanisms to } \\
\text { achieve higher levels of pub- } \\
\text { lic well-being and prosperity. }\end{array}$ & $\begin{array}{l}\text { Establishes the objective of } \\
\text { working toward the sustain- } \\
\text { able development of the mu- } \\
\text { nicipality by taking measures } \\
\text { to provide for the expansion } \\
\text { of water coverage in rural } \\
\text { areas. }\end{array}$ \\
\hline \multicolumn{3}{|c|}{$\mathrm{LaPaz}$} \\
\hline $\begin{array}{c}\text { Ley de Hacienda para } \\
\text { el Municipio de La Paz, Baja } \\
\text { California Sur }(\mathrm{La} \\
\text { Paz Taxation Act) } \\
\text { BOGE, } 31 \text { March 2001; } \\
\text { latest revision, BOGE, } 10 \\
\text { December } 2017\end{array}$ & $\begin{array}{l}\text { Establishes taxes, fees, pro- } \\
\text { ceeds, payments, remittances, } \\
\text { and extraordinary revenues } \\
\text { for the administrative expen- } \\
\text { ses of the municipality. }\end{array}$ & $\begin{array}{l}\text { Establishes the fees payable } \\
\text { for the supply of water, drain- } \\
\text { age, sewer, and wastewater } \\
\text { treatment and disposal ser- } \\
\text { vices. }\end{array}$ \\
\hline $\begin{array}{c}\text { Reglamento de } \\
\text { Protección al Medio } \\
\text { Ambiente (Environmental } \\
\text { Protection Bylaws) } \\
\text { BOGE, } 10 \text { October } 1995\end{array}$ & $\begin{array}{l}\text { Lays the foundation for the } \\
\text { preservation, conservation and } \\
\text { restoration of ecological equi- } \\
\text { librium and for environmen- } \\
\text { tal improvement on the mu- } \\
\text { nicipality's territory as well as } \\
\text { for the prevention and con- } \\
\text { trol of water pollution. }\end{array}$ & $\begin{array}{l}\text { Establishes the division of ju- } \\
\text { risdiction. } \\
\text { Chapter } 10 \text { covers the pre- } \\
\text { vention and control of water } \\
\text { pollution and sets out provi- } \\
\text { sions relating to wastewater } \\
\text { discharges. }\end{array}$ \\
\hline
\end{tabular}


Esta revista forma parte del acervo de la Biblioteca Jurídica Virtual del Instituto de Investigaciones Jurídicas de la UNAM

\begin{tabular}{|c|c|c|}
\hline \multicolumn{3}{|c|}{ Municipal } \\
\hline Provision & Objective & Relevance \\
\hline $\begin{array}{c}\text { Reglamento de Uso } \\
\text { de la Red de Alcantarillado } \\
\text { Sanitario del OOMSAPAS } \\
\text { La Paz (La Paz Sewer } \\
\text { Use Bylaws) } \\
\text { BOGE, 20 February } 2007\end{array}$ & $\begin{array}{l}\text { To prevent and control water } \\
\text { pollution, compliance by per- } \\
\text { sons responsible for wastewa- } \\
\text { ter discharges into the sewer } \\
\text { system is compulsory. }\end{array}$ & $\begin{array}{l}\text { Governs wastewater dischar- } \\
\text { ges other than domestic dis- } \\
\text { charges, as well as the particu- } \\
\text { lar conditions of discharge in } \\
\text { accordance with the maxi- } \\
\text { mum permissible pollutant li- } \\
\text { mits established in NOM-00 } \\
\text { 2-SEMARNAT-1996. } \\
\text { Provides that La Paz Water } \\
\text { and Sewer Authority, which } \\
\text { has responsibility for the wa- } \\
\text { ter supply, sewage system, and } \\
\text { water treatment services is al- } \\
\text { so responsible for enforcing } \\
\text { this bylaw. }\end{array}$ \\
\hline $\begin{array}{l}\text { Programa de Desarrollo } \\
\text { Urbano de Centro } \\
\text { de Población de La Paz, } \\
\text { BCS (La Paz Urban } \\
\text { Development Program) } \\
\text { Latest revision, } 2018 \\
\text { https://wrere.comovamosla } \\
\text { paz.org/wp-content/up } \\
\text { loads/2018/07/PDUCP- } \\
\text { La-Paz-2018.pdf }\end{array}$ & $\begin{array}{l}\text { Establishes mechanisms for } \\
\text { the regulation, management } \\
\text { and promotion of an integra- } \\
\text { ted territorial planning sche- } \\
\text { me to assess the impacts of } \\
\text { economic, touristic and urban } \\
\text { development, and for the re- } \\
\text { covery and restoration of the } \\
\text { region's historical heritage and } \\
\text { natural environment. }\end{array}$ & $\begin{array}{l}\text { Provides an overview of the } \\
\text { wastewater regime and also } \\
\text { the prevailing situation in the } \\
\text { Municipality. } \\
\text { Recognizes the potential pro- } \\
\text { blem of contamination due to } \\
\text { wastewater and urban waste. } \\
\text { Sets forth the strategy "Zero } \\
\text { wastewaters to the sea" thro- } \\
\text { ugh the introduction of new } \\
\text { water treatment plants, reha- } \\
\text { bilitation of existing plants, } \\
\text { new collectors, replacement } \\
\text { of sanitary sewer pipes, and } \\
\text { also the generation of studies } \\
\text { on resource sanitation and } \\
\text { the areas where water is dis- } \\
\text { charged. }\end{array}$ \\
\hline \multicolumn{3}{|c|}{ Los Cabos } \\
\hline $\begin{array}{c}\text { Ley de Hacienda para el } \\
\text { Municipio de Los Cabos, } \\
\text { Baja California Sur (Los } \\
\text { Cabos Taxation Act) } \\
\text { BOGE, } 5 \text { November 2001; } \\
\text { latest revision, BOGE, } 20 \\
\text { December } 2017\end{array}$ & $\begin{array}{l}\text { Governs the matters relating } \\
\text { to the revenues that constitute } \\
\text { the Municipal Public Treasu- } \\
\text { ry, consisting of the collection } \\
\text { of taxes, fees, proceeds, and } \\
\text { other revenues. }\end{array}$ & $\begin{array}{l}\text { Establishes the fees payable } \\
\text { for the supply of water, drai- } \\
\text { nage, sewer, and wastewater } \\
\text { treatment and disposal ser- } \\
\text { vices. } \\
\text { Establishes the obligation of } \\
\text { property owners or occupants } \\
\text { to pay wastewater treatment } \\
\text { and disposal fees. }\end{array}$ \\
\hline $\begin{array}{l}\text { Reglamento Municipal } \\
\text { del Equilibrio Ecológico } \\
\text { y Protección al Ambiente }\end{array}$ & $\begin{array}{l}\text { Governs the preservation and } \\
\text { restoration of the ecological } \\
\text { equilibrium as well as the pro- }\end{array}$ & $\begin{array}{l}\text { Establishes the powers of the } \\
\text { municipal council to supervi- } \\
\text { se and enforce the provisions }\end{array}$ \\
\hline
\end{tabular}


Esta revista forma parte del acervo de la Biblioteca Jurídica Virtual del Instituto de Investigaciones Jurídicas de la UNAM

\begin{tabular}{|c|c|c|}
\hline \multicolumn{3}{|c|}{ Municipal } \\
\hline Provision & Objective & Relevance \\
\hline $\begin{array}{c}\text { (Municipal Environmental } \\
\text { Protection Bylaws) } \\
\text { BOGE, } 20 \text { May } 2008\end{array}$ & $\begin{array}{l}\text { tection of the environment } \\
\text { and the municipality's cultu- } \\
\text { ral heritage. Aims at improv- } \\
\text { ing environmental quality and } \\
\text { the quality of life for the mu- } \\
\text { nicipality's residents, and pro- } \\
\text { viding for the sustainable en- } \\
\text { joyment of natural resources } \\
\text { and their increase. }\end{array}$ & $\begin{array}{l}\text { applicable to wastewater dis- } \\
\text { charges into the sewer system. } \\
\text { Title } 2 \text {, Chapter } 6 \text { governs } \\
\text { the prevention and control of } \\
\text { water pollution arising from } \\
\text { industrial and other activity. }\end{array}$ \\
\hline $\begin{array}{l}\text { Reglamento del Uso de la } \\
\text { Red de Alcantarillado del } \\
\text { Municipio de Los Cabos, } \\
\text { Baja California Sur (Los } \\
\text { Cabos Sewer Use Bylaws) } \\
\text { BOGE, } 31 \text { May } 2014 \\
\text { https://aguapotabledeloscabos. } \\
\text { gob.mx/leyes-y-reglamentos/ }\end{array}$ & $\begin{array}{l}\text { Compliance with the provi- } \\
\text { sions of this bylaw is manda- } \\
\text { tory in the municipality of } \\
\text { Los Cabos for users discharg- } \\
\text { ing wastewater, and for both } \\
\text { natural and legal persons who } \\
\text { discharge wastewater into the } \\
\text { municipal sewer system under } \\
\text { the responsibility of the Los } \\
\text { Cabos Water and Sewer Au- } \\
\text { thority. }\end{array}$ & $\begin{array}{l}\text { Guarantees the proper treat- } \\
\text { ment of municipal wastewa- } \\
\text { ter and also the prevention of } \\
\text { water and soil contamination } \\
\text { through the regulation of was- } \\
\text { tewater discharges into the } \\
\text { municipal sewer system, and } \\
\text { specifies the appropriate con- } \\
\text { ditions of discharge, in accor- } \\
\text { dance with the maximum per- } \\
\text { missible limits for pollutants } \\
\text { discharged into drainage sys- } \\
\text { tems under NOM-002-SEM } \\
\text { ARNAT-1996. } \\
\text { Governs the treatment, man- } \\
\text { agement, reuse, and final dis- } \\
\text { posal of wastewater processed } \\
\text { by treatment plants operating } \\
\text { in the municipality of Los Ca- } \\
\text { bos, pursuant to NOM-001- } \\
\text { SEMARNAT-1996 and NO } \\
\text { M-003-SEMARNAT-1997. }\end{array}$ \\
\hline $\begin{array}{c}\text { Reglamento del Organismo } \\
\text { Descentralizado Operador } \\
\text { del Sistema de Agua Potable } \\
\text { y Alcantarillado del } \\
\text { Municipio de Los Cabos } \\
\text { (Los Cabos Water and Sewer } \\
\text { Authority Bylaws) } \\
10 \text { October } 1996\end{array}$ & $\begin{array}{l}\text { Regulates the provision of } \\
\text { drinking water and sewage } \\
\text { services by the Water and Se- } \\
\text { wer Authority. }\end{array}$ & $\begin{array}{l}\text { Sets out the Authority's du- } \\
\text { ties and powers, which inclu- } \\
\text { de providing, administering, } \\
\text { and overseeing the water sup- } \\
\text { ply and sewer services. } \\
\text { Establishes the objective of } \\
\text { promoting the reuse of sew- } \\
\text { age and wastewater. }\end{array}$ \\
\hline $\begin{array}{c}\text { Plan de Desarrollo } \\
\text { Municipal, Ayuntamiento } \\
\text { de Los Cabos 2018-2021 } \\
\text { (Los Cabos Municipal } \\
\text { Development Plan } \\
\text { 2018-2021) }\end{array}$ & $\begin{array}{l}\text { Establishes projects, actions, } \\
\text { and goals that should be un- } \\
\text { dertaken to help guide the de- } \\
\text { velopment of the municipal } \\
\text { government's public policies. }\end{array}$ & $\begin{array}{l}\text { States that wastewater dis- } \\
\text { charges are the main source } \\
\text { of contamination. } \\
\text { Identifies the source points } \\
\text { and establishes actions and } \\
\text { policies designed to alleviate } \\
\text { the problem. }\end{array}$ \\
\hline
\end{tabular}

Available at: $h t t p: / /$ wrewe.ordenjuridico.gob.mx/estatal.php?'liberado $=$ siEंedo $=3$.

SOURCE: Authors. 
After reviewing the tables above, one might conclude that there is an extensive legal framework in BCS governing the prevention of water pollution and the protection of its water resources. All three levels of government have indeed regulated wastewater within their spheres of jurisdiction, and all governmental agencies have been assigned various duties and responsibilities in relation to wastewater discharges and the control of both water and soil pollution. However, the legal framework for wastewater still remains at an early stage of development in the sense that it has focused primarily on preventing pollution by the granting of discharge permits for a fee, and using the pollutant limits set out in the Official Mexican Standards as the yardstick for such grants.

Despite this shortcoming, the plans, programs and public policies put in place by the three levels of government show that wastewater reduction and reuse have become priorities. The first step toward making reuse an enforceable obligation is for it to be clearly specified in federal, state, and local laws. But the continuing problems associated with the improper management of wastewater discharges show that legislation alone may be insufficient. Despite the existence of an extensive network of wastewater treatment regulations, water pollution is, in fact, on the rise. Thus, research on this issue must focus on the degree to which these statutory obligations are actually being enforced. To that end, wastewater-related laws must be analyzed to determine whether the negative impact on the environment and the nation's natural resources are being caused by shortcomings in the legislation itself, or by the improper administration and enforcement of the existing wastewater regulations.

\section{Dynamic Analysis}

The final step in our methodology is to analyze the legal framework outlined above with reference to four criteria: the law-making process (elaboration), interpretation, enforcement, and extinction of the law. ${ }^{57}$

Law-making process. This refers to the specific process by which laws, regulations, and standards are created. This rule of analysis is important because it determines which law takes precedence so that it can be applied by the relevant authorities to the regulated community. In Mexico, the federal Congress enacts federal and general laws; ${ }^{58}$ state congresses pass state laws, ${ }^{59}$ and city councils (ayuntamientos) adopt bylaws. ${ }^{60}$ The Official Mexican Standards are drafted according to the process set out in the Federal Metrology and Stan-

57 Carmona Lara, supra note 13, at 33.

58 Constitución Política de los Estados Unidos Mexicanos [Const.], supra note 24, art. 73 frac. XXIX G, 133.

59 Constitución Política del Estado de Baja California Sur [B.C.S State Constitution], as amended, Boletín Oficial del Gobierno del Estado de Baja California Sur [B.O.G.E.B.C.S.], 15 de enero de 1975 (Mex.). Art. 64 frac. II.

60 Constitución Política de los Estados Unidos Mexicanos [Const.], supra note 24, art. 115 frac. II. 
dardization Act (Ley Federal sobre Metrología y Normalización), issued by the Federal Executive Branch, and are applicable throughout Mexico. ${ }^{61}$

The authority to enact legislation, monitor compliance, and enforce wastewater related regulations is determined by the Constitution, the Ecological Protection Law (LGEEPA), and the National Waters Act (Ley de Aguas Nacionales). These laws are then reinforced by state and municipal laws. Federal authorities are responsible for the protection and preservation of national waters. State authorities are responsible for the prevention and control of contamination to waters under state jurisdiction, as well as any national waters to which they have been assigned responsibility. Municipal authorities are responsible for the prevention and control of contamination to waters discharged into municipal sewer systems, and, again, any national waters placed under their authority. ${ }^{62}$

Interpretation. Each law typically specifies the rules for its own interpretation. However, Mexico's wastewater laws do not do so. As a result, interpretation of each law's meaning and scope must be derived from general rules of legal interpretation. Interpretation begins with any definitions set forth within the particular law itself that assist in its interpretation or the clarification of its key principles and concepts. ${ }^{63}$ The consistently defined principles and concepts underlying wastewater regulations help to unify the overall legal framework, even though it is comprised of distinct federal, state, and municipal laws. Interpretation of the laws under examination in this study was facilitated by the tables presented above, which provide a comprehensive overview of all waterrelated regulations and simplify the analysis of the connections between them.

Enforcement. The first step in analyzing the enforcement of wastewater law is to determine which law applies in any specific case. In the case of BCS, this requires an understanding of the entire Mexican legal framework and its various levels, federal, state, and municipal, in order to determine which principles, rights, and obligations apply. As has been shown, BCS is subject to an extensive set of regulations concerning wastewater, yet the state continues to suffer from problems that inhibit sustainable development. Effective enforcement requires targeted government action, including the assignment of adequate budgets for enforcement authorities, the investigation of violations, the application of sanctions, training for inspectors, provisions for transparency, and access to information. ${ }^{64}$ Also, clear procedures must be outlined that enable citizens to directly notify the appropriate authorities and thereby assist in the enforcement of the laws and the sanctioning of violators.

61 Ley Federal sobre Metrología y Normalización [L.F.M.N.] [Federal Metrology and Standardization Act] as amended, Diario Oficial de la Federación, 1 de julio de 1992 (Mex.). Last amended 30 de abril de 2009.

62 See Articles 27 and 115 of the Const., Articles 5, 7, and 8 of the L.G.E.E.P.A., and articles 6 and 9 of the National Waters Act.

63 See article 3 of the National Waters Law, and 3 of the L.G.E.E.P.A.

64 Carmona Lara, supra note 13, at 41. 
In many respects, the manner in which legal and administrative powers have been divided among the three levels of government suggests that the intent was to establish joint responsibility among SEMARNAT, CONAGUA, the federal health authorities, and the state and municipal agencies regarding the enforcement of wastewater law. However, the specific functions and duties of each authority has not been clearly delineated, and this has led, ultimately, to a failure to act. Put simply, these shared responsibilities mean it is not always clear who does what when it comes to water-related policymaking and enforcement.

Extinction. The general rule states "The passage of a law repeals the previous law". Thus, to determine which law is currently in force, one must ascertain which amendment or revision of the law is the most recent. Federal laws are published in the Official Gazette of the Federation (Diario Oficial de la Federación), while BCS state laws appear in that state's Official Bulletin (Boletin Oficial del Gobierno de Baja California Sur). Even though the aforementioned rule may be simple, inconsistent procedures regarding the publication of revisions or amendments by the various levels of government has led to a situation in which many of these revisions or amendments, mostly at the state and municipal levels, are not, in fact, published or accessible. This means that it is often difficult to determine which law is currently in force, and is therefore of little use to citizens and other interested parties who could otherwise benefit by having access to accurate information. Nevertheless, the tables presented above contain an up-to-date listing of all wastewater-related laws that are currently in force in Mexico.

\section{Gonclusions}

This analysis and schematization of Mexico's legal framework regarding wastewater can be used as a guide by legislators, public servants, academics, and members of the general public who wish to obtain a better understanding of how it operates. As previously stated, it is not sufficient to analyze the federal provisions alone. Due to the overlapping jurisdictions of the different levels of government on this subject, state and municipal provisions must also be included in any analysis. To achieve a level of wastewater management compatible with environmental sustainability and protect the nation's water resources for current and future generations, the effectiveness of this legal framework must be maximized. This can only be accomplished after understanding how the entire integrated system of applicable laws and public policies functions, and then determining which laws need to be amended, and in what manner.

To help clarify the extensive and intricate legal framework involving wastewater in Mexico, and, in particular, to assess the compatibility of the various wastewater-related regulations existing at the federal, state, and municipal levels, we conducted a systematic analysis of this corpus. Further research can 
capitalize on this first step in order to evaluate the overall effectiveness of the current legal framework. Although much progress has been made in the implementation of laws and standards governing wastewater at the federal, state, and local levels, the critical water shortage in Mexico and in BCS - a waterstressed state anticipating a rapid increase in population and water demandsuggests a need for the development and implementation of new strategies for water conservation. At a minimum, such strategies should include vastly increasing the treatment and reuse of wastewater, and establishing strict water reclamation and recycling standards. These will only be achieved through the enactment of effective, targeted regulations and a strict enforcement regime.

The development of wastewater legislation is constantly evolving as specific problems become apparent. This development parallels a similar trend in environmental law in general. However, the aim of most current regulation is directed principally at the prevention of pollution. Under this approach, the generation, collection, treatment, reuse, and final disposal of wastewater are addressed by means of regulations dealing with discharge licenses and permits, various fees and duties, and the enforcement of official standards covering water quality. At the municipal level, the bylaws enacted typically limit their focus to the regulation of public services, such as water delivery and sanitation. Although the concept of wastewater reuse does appear in these regulations and has been incorporated into development and environmental plans and programs at various levels, it is not currently a legally enforceable obligation. A paradigm shift recognizing wastewater reuse as a possible solution to the issue of water scarcity will require amending federal, state, and municipal legislation, converting wastewater reuse into a legal obligation, and thereby placing it on an equal footing with wastewater treatment.

A new line of research is therefore needed on the effectiveness of the currently existing, incentives-based model encouraging wastewater reuse, and, on the benefits that a mandatory approach would require for it to be viable. In agricultural production, for example, wastewater is insufficiently regulated, and producers often find that absorbing fines is cheaper than treating wastewater. New legislative measures must eliminate these types of economic disincentives to conservation. In the short term, wastewater regulations should be amended to require the full treatment of wastewater so that it is brought up to a reusable standard. For this to occur, the law must cover the entire process, from generation to routing to treatment and reuse. However, given the fragmented legal framework currently in place in BCS, with each governmental authority being responsible for only a specific part of the wastewater process, any reuse regime would be rendered ineffective. This is a significant problem considering BCS is a region where, at present, only $58.3 \%$ of the wastewater collected through the state's sewer systems is being treated before being reused or returned to a body of water.

The enforcement apparatus of the current legal framework related to wastewater is another factor that must be analyzed in order to ascertain its 
effectiveness. As stated above, the existence of overlapping responsibilities has complicated the issue of enforcement. Resolution of this problem will require encouraging coordination among authorities at the various levels, providing adequate institutional funding, and specifically defining the roles played by each governmental agency.

The most significant obstacle to the completion of this study was locating and compiling the relevant information and legislation due to the fact that there is no uniformity among the five municipalities of BCS, and not all regulations and bylaws are available online. Municipal bylaws are particularly elusive: some do not exist in any accessible form, others are outdated, and still others have not been renewed since 2018. None of these provisions are included at the website of the federal Congress, and municipal sites are frequently out of date or offline altogether. An important first step in facilitating research and investigation in this area would be the creation of a straightforward and up-to-date online compilation of all municipal laws, one that is both publicly accessible and easy to navigate. 
Esta revista forma parte del acervo de la Biblioteca Jurídica Virtual del Instituto de Investigaciones Jurídicas de la UNAM juhttp://www.juridicas.unam.mx/ https://biblio.juridicas.unam.mx/bjv DOI: http://dx.doi.org/10.22201/iij.24485306e.2021.2.15339

https://revistas.juridicas.unam. mx/ 


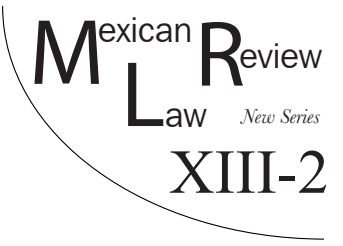

\title{
CORRUPTION, RULE OF LAW AND DEMOCRACY: CONGEPTS, BOUNDARIES AND OXYMORA
}

\author{
Stephen D. MORRIs*
}

\begin{abstract}
Despite heightened attention to corruption, multiple reform efforts, and democratization in the past few decades, corruption remains stubbornly persistent throughout the world. Much of the research on corruption highlights an inverse relationship linking corruption to the rule of law and to democracy. But rather than concentrate on the relationships among these critical variables, this research note focuses its attention on the intense debates in the literature over how to define these key concepts and the competing definitions. Analysis differentiates thin and thick definitions of each of the three concepts, highlights their shared emphasis on limiting state power and their use of vague criteria to demarcate the conceptual boundaries. Amid intense debate, all three essentially ground their limits on state power on rather vague notions of justice, equality, or the common or public good. The main argument here is that in many cases this results in a conceptual overlap and blurred boundaries. Depending on the definition employed, corruption can be seen as conceptually embedded within the notion of the rule of law which, in turn, is encompassed within our understanding of democracy. At one level, these common conceptual components potentially fashion tautologies and oxymora, complicating questions about the theoretical relationships among them: is it even possible for a country to have high levels of corruption and strong rule of law? Or high levels of corruption and yet still be considered democratic? At an empirical level, the conceptual overlap complicates the examination of such theoretical linkages because of endogeneity potential. I illustrate this problem briefly by noting how in some cases the indices of democracy encompass measures of the rule of law or corruption, and vice versa. The essay concludes
\end{abstract}

* Ph.D. from the University of Arizona. Researcher, Coordinación de Humanidades, Coordinador of the Laboratorio de la Documentación y Análisis de la Corrupción y Transparencia, Instituto de Investigaciones Sociales, UNAM and profesor of political science and international relations (on leave), Middle Tennessee State University. Contact: stephen.morris@humanidades.una m.mx and stephen.morris@mtsu.edu. Recent works include Corruption and Democracy in Latin America (co-edited with Charles Blake, 2009), and Corruption and Politics in Latin America: National and Regional Dynamics (co-edited with Charles Blake, 2010).

An earlier version of this note was presented at the XXXII International Congress of the Latin American Studies Association, May 21-24, 2014, Chicago, IL. 
Esta revista forma parte del acervo de la Biblioteca Jurídica Virtual del Instituto de Investigaciones Jurídicas de la UNAM

by highlighting how disaggregating the concepts raises other interesting questions and analytical challenges.

Keywords: Corruption, Rule of law, democracy, definitional debates, issues of endogeneity.

RESUMEN: A pesar de una mayor atención a la corrupción, esfuerzos varios en reformas, y una búsqueda por la democratización en las últimas décadas, la corrupción sigue aferrada por todo el mundo. Gran parte de las investigaciones realizadas sobre corrupción subrayan una relación inversa entre esta, el estado de derecho, y la democracia. En vez de concentrar la atención sobre las relaciones entre estas tres variables, la nota actual se enfoca en los debates contenciosos en la literatura sobre cómo definir estos conceptos claves, y las definiciones encontradas. El análisis destaca las distintas definiciones, tanto en sentido amplio como en estricto de cada uno de los tres conceptos, así como identificar el énfasis compartido sobre la limitación del poder del estado y su uso de criterio ambiguo para demarcar las fronteras conceptuales. Dentro de los debates, los tres conceptos esencialmente fundamentan los límites del poder estatal en ideas como justicia, igualdad, y el bien común o público. El argumento principal aqui es que en muchos casos esto resulta en la coincidencia conceptual produciendo fronteras borrosas. Según la definición estricta o amplia que se utilice, la corrupción se puede ver como incorporada dentro de la noción del estado de derecho, la cual, a su vez, está envuelta dentro del concepto de democracia. Los componentes compartidos pueden crear tautologías y oxímoros, complicando cuestiones teóricas entre los tres: ¿Es posible que un país sufra altos niveles de corrupción y también contar con un estado de derecho fuerte? $O$, ¿puede contar con altos niveles de corrupción, como corrupción electoral, y al mismo tiempo, ser una democracia? En adición, las coincidencias conceptuales complican cualquier investigación empirica sobre las relaciones entre la corrupción, estado de derecho y democracia por la posibilidad de endogamia. Ilustro este problema haciendo notar cómo en algunos casos los índices de la democracia incluyen mediciones del estado de derecho o corrupción. Desagregar estos conceptos también resalta otras inquietudes y retos analíticos.

Palabras claves: Corrupción, Estado de derecho, democracia, debates conceptuales, problemas de variables endógenas.

\section{TABLE OF Contents}

I. INTRODUCTION.............................................................................. 155

II. Definitions, Goncepts and Overlap ....................................... 156

1. Corruption ..................................................................... 157

2. Rule of Law .................................................................... 161

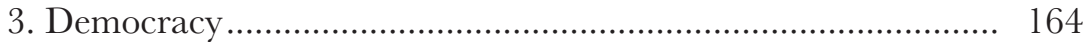

III. Relationships Among Overlapping Concepts ......................... 167

IV. Conclusion: So? .............................................................. 170 
The British learned late in the eighteenth century that "influence" is nothing but a euphemism for "corruption", but contemporary political science chose to ignore this lesson. ${ }^{1}$

Adam PrZeworski

\section{INTRODUCTION}

Despite intense scholarly and political attention, multiple reforms, and theoretical and ideological expectations that corruption should wither as a result of expanding democratic and even neoliberal reforms,${ }^{2}$ corruption remains prevalent and stubbornly persistent throughout the world. In many countries today, despite empirical work showing correlations linking lower levels of corruption to both democracy and the rule of law, corruption and democracy seem to coincide. Weak rule of law and impunity seem to co-exist alongside "free and fair" elections, and the paucity of confidence in democratic institutions shadows the public's support for democracy as a system. Like many other countries, Mexico clearly fits this pattern.

At a fundamental level, these perplexing cocktails raise conceptual and theoretical questions, that possibly consists an oxymoron. Is it even possible for a country to be democratic and at the same time endure high levels of corruption or a weak rule of law? Could such a country strengthen its democracy while continuing to suffer high rates of corruption, impunity, and weak rule of law? If so, then how much (or what sorts of) corruption or un-rule of law is required to disqualify a country as being democratic? Could thresholds or criteria be established to differentiate acceptable from unacceptable levels of electoral fraud or the arbitrary use of power, or duplicitous exclusionary decision-making practices, or injustice, or impunity to deem a country as a non-democracy? Or do all three of these work alongside so that lowering corruption and strengthening the rule of law are part of becoming (more) democratic and vice versa? Essentially, are they different phenomena, or are they encased within one another located at higher and lower orders, or do they all refer fundamentally to the same things?

I pretend neither to answer all these questions here, explore the empirical or theoretical relationship linking these three variables, nor analyze them in relation to the Mexican case. Instead, the questions posed seek to underline the importance of conceptual clarity. After all, to even imagine a theoretical, causal relationship linking two or more variables, much less to test it empiri-

1 Adam Przeworski. Democracy and the limits of Self-government 97 (Cambridge University Press, 2010).

2 Anna Persson, Bo Rothstein, and Jan Teorell, Why Anticorruption Reforms Fail - Systemic Corruption as a Collective Action Problem, 26 (3) Governance: An International Journal of Policy Administration and Institutions 449-47 1 (2013). 
cally, it is necessary to rigorously define and measure the concepts in such a way that they are independent of one another. Yet as a conceptual exploration of competing thin and thick definitions and measures of corruption, rule of law, and democracy, it is somewhat difficult to see the three concepts as entirely separate and mutually exclusive, or as focusing on distinct phenomena. Conceptually, I argue, corruption is contained within most notions of the rule of law, just as the rule of law resides within most definitions of democracy. Broader or thicker definitions of both corruption and the rule of law further blur these conceptual boundaries by defining the terms along clearly democratic lines, just as thicker definitions of democracy encompass minimal levels of corruption, effective accountability, and rule of law. Much of this conceptual overlap stems from two common underlying components of these concepts: a shared concern for limiting state power, and the use of vague criteria rooted in notions of justice, equality, or the common good to demarcate those limits.

\section{Definitions, Goncepts and Overlap}

Despite intense debate and competing formulas, definitions of corruption, rule of law, and democracy, they share some important attributes as this review seeks to show. First, in one form or another, they all refer to limits on state power and/or the conduct of state officials. In Joseph Nye's classic and widelycited definition, for instance, corruption refers to behavior by a public official that deviates from the formal duties of a public office for personal gain. ${ }^{3}$ As such, corruption represents a breach of the normative limits placed on the conduct of state officials. In a similar manner, the rule of law also seeks to limit state power. At minimum, rule of law means that state officials must, like everyone else, abide by the law and respect certain limits on the arbitrary use of power. Democracy too is all about limiting the power of state officials. In the very least, democracy limits the mechanisms for selecting political leaders, and to some extent what governments can and cannot do. "Democracy's sweeping discretionary powers must operate through some set of decision rules and may not be used to violate core rights and periodic elections". "As Francis Fukuyama acknowledges, "Modern democracy was born when rulers acceded to formal rules limiting their power". ${ }^{5}$

The mere fact that all three concepts seek to limit state power creates a degree of conceptual overlap with each lower-level concept seemingly contained within the higher-level concept. Most notions of corruption are encompassed within our understanding of the rule of law, just as some basic

3 Joseph S. Nye, Corruption and Political Development: A Cost-Benefit Analysis, 61 American Poutitical Science Review 417-427 (1967).

4 Gerard Alexander, Institutionalized Uncertainty, the Rule of Lare, and the Sources of Democratic Stability, 35 Comparative Political Studies 1159 (2002).

5 Francis Fukuyama, The Necessity of Politics, in Essential Readings in Comparative PoliTics 33 (Patrick H. O’Neil and Ronald Rogowski eds., 2013). 
standards of the rule of law nestle within most definitions of democracy. In the simplest of terms this means that corrupt officials fail to abide by the rule of law, while countries that violate certain laws or rules - like those governing elections (i.e. staging them) - can hardly be considered democratic.

Beyond limiting state power, definitions of corruption, rule of law, and democracy also share two other ingredients. The first resides in the intense disagreement over how to define or specify those limits on state power or the conduct of state officials. In fact, specifying the norms that delimit the conduct of state officials, the law, or a democratic state, constitutes the rub of much of the conceptual debate featured in the abundant literature, and the key ingredient separating thin from thick definitions as described in detail below. Second, many definitions of corruption, rule of law, and democracy share a tendency to rely on fundamental principles of democracy, justice, equality, or the common good to define or demarcate these limits on state power. This shared dimension nurtures even greater conceptual overlap, and potential tautologies at the empirical level. Generally, the "thicker" the definition, the greater the overlap among the three concepts.

\section{Corruption}

The primary problem in defining corruption is to specify the standards that constitute the "norms" that an act of corruption violates. ${ }^{6}$ At one end of the spectrum, what can be called a thin definition of corruption tends to rely primarily on the law or the formal rules of public office to define, and identify an individual act as being corrupt. This is largely what Nye meant by the formal duties of public office. While using the law as the standard makes it easy to identify, gauge, and even quantify corruption, this approach has always raised questions. ${ }^{7}$ Not only can the law itself be the by-product of corruption and is usually determined by the politically powerful, but it also leaves open the matter of the criteria that should be used in making the law. ${ }^{8}$ Early on, analysts questioned the legal-based definition to suggest other criteria to define corrup-

6 An additional problem is the inclusion of private or personal gain in most definitions. As noted later, Dennis F. Thompson, Two Concepts of Corruption, Harvard University, Edmond J. Safra Center for Ethics, Working Papers, No. 16 (2013) distinguishes corruption involving private gain from corruption involving political gain. I argued many years back that from a rational choice perspective all acts are considered a function of personal gain, therefore, including it in a definition seems odd. Arguably all acts of public officials, corrupt and non-corrupt, are promoted by personal gain (Stephen D. Morris, Corruption and Politics in Contemporary Mexico 4 (University of Alabama Press, 1991).

7 Arnold J. Heidenheimer, ed., Political Corruption: Readings in Comparative Analysis (Transaction Books, 1970) and Mark Philp, Defining Political Corruption XLV Political STUdIES (1997).

8 L. L. Berg, H. Hahn and J. R. Schmidhauser, Corruption in the American Political System (General Learning Press, 1976). 
tion such as the common good or even public opinion, but these too quickly revealed their shortcomings. Of course, the use of any of these three earlier standards to demarcate corruption raises the question as to whether corruption can be legal, functional or popular.

More recent approaches in the study of corruption, however, broaden or "thicken" the definition in at least two important respects. ${ }^{9}$ First, these thick definitions define corruption not as a form of individual behavior, but as systemic. A reflection of how classical thinkers thought of corruption, this view envisions corruption as a form of rule that violates certain norms rather than considering it as individual acts. ${ }^{10}$ Michael Johnston, for example, characterizes corruption as a systemic problem having to do with the sources, uses, limits, and accountability of wealth and power: a form of influence that distorts decision-making, thereby diverting the costs and benefits of policy. ${ }^{11}$ Corruption defined in individualistic terms, Mark Warren contends, makes it difficult to conceive of "institutional corruption in which covert norms of exchange within an institution - access in exchange for campaign donations, for example - corrupt the overt purposes of the institution". ${ }^{12}$

But viewing corruption as systemic rather than individualistic still leaves unresolved the issue of how to define the norms or standards that constitute corruption. It is here where these new systemic approaches reach beyond the law (or public opinion or common good) to tap key principles of democracy denoting the standard or norm that corruption violates. Casting political inclusiveness as the key, for example, Warren conceptualizes corruption as the "duplicitous exclusion" of those affected by political decisions from exercising influence over those decisions. ${ }^{13}$ Corruption, he argues, "breaks the link be-

9 Ulrich Von Alemann, The Unknown Depths of Political Theory: The Case for a Multidimensional Concept of Corruption 42, Crime, Law \& Social Change (2004).

10 According to John Joseph Wallis, The Concept of Systematic Corruption in American History, in Corruption and Reform: Lessons from America's Economic History 25 (Edward L. Glaeser and Claudia Goldin, eds., 2006) this systemic view of corruption, wherein "politicians deliberately create rents by limiting entry into valuable economic activities, through grants of monopoly, restrictive corporate charters, tariffs, quotas, regulations, and the like... rents [which] bind the interests of the recipients to the politicians who create them", actually prevailed in the U.S. up to the Progressive Era. At that point, the individualist view became the accepted definition.

11 Michael Johnston (1997), Public Officials, Private Interests, and Sustainable Democracy: When Politics and Corruption Meet, in Corruption and the Global Economy (Kimberly Ann Elliott, ed. 1997); Michael Johnston, Democracy without Politics? The Hidden Costs of Corruption and Reform in America, in Corruption and American Politics 17 (Michael A. Genovese and Victoria A. Farrar-Myers, eds. 2010).

12 Mark E. Warren, What Does Corruption Mean in a Democracy? 48 (2) American Journal of Political Science, 331 (2004).

13 Ibid; Mark E. Warren, Political Corruption as Duplicitous Exclusion 39 (4) PS: Political ScIence and Politics (2006); and Mark E. Warren, Is Low Trust in Democratic Institutions a Problem of Corruption? in Corruption and American Politics (Michael A. Genovese and Victoria A. Farrar-Myers, eds., 2010). 
tween collective decision making and people's powers to influence collective decisions"; [and as a result] "reduces the effective domain of public action... by reducing public agencies of collective action to instruments of private benefit". ${ }^{14}$

Dennis Thompson, Lawrence Lessig, and Irma Sandoval-Ballesteros build further on Warren and Johnston's systemic approach. Thompson defines corruption as "a condition in which private interests distort public purposes by influencing the government in disregard of the democratic process". ${ }^{15}$ Shortly, whereas Warren points to the illegitimate exclusion of people from the decision making process, Thompson's systemic view seems to stress the illegitimate or privileged inclusion of others who bypass and hence undermine the democratic process to gain influence. Rather than duplicitous exclusion, the key democratic principle for Thompson, therefore, is whether the practice promotes political competition, citizen representation or other core processes of the democratic institution, or whether it undermines them, thereby weakening the independence of the institution. Lessig largely agrees with Thompson's formulation, but questions his notion of "institutional independence" by noting how the U.S. Congress is not expected to be independent, at least not from the will of the people. ${ }^{16}$ Consequently, Lessig coins the concept of "dependence corruption". In "dependence corruption" members of Congress are not only dependent on the moneyed interests that make their survival possible despite elections, but there is also no incentive by those benefiting from it to contest or reform the system. "The sin of a Congressman within such a system is not that she raises campaign money", Lessig notes. "It is that she doesn't work to change the corruption that this dependence upon a small set of funders has produced". ${ }^{17}$ But it is not merely that corruption undermines or affects principles of justice and legitimacy as the orthodox or thin view tends to suggest, ${ }^{18}$ but, the fact that corruption by definition constitutes a violation of the principles of justice and legitimacy.

Sandoval-Ballesteros's concept of "structural corruption" goes a step (or two) further. She defines corruption as a "specific form of social domination characterized by abuse, simulation, and misappropriation of resources arising from a pronounced differential in structural power". ${ }^{19}$ In broadening the

14 Warren, supra note 12.

15 Thompson, supra note 6.

16 Lawrence Lessig, Institutional Corruption, Edmond J. Safra Working Papers, No. 1, Harvard University, Edmond J. Safra Center for Ethics (March 15, 2013); Lawrence Lessig, Republic Lost: How Money Corrupts Congress - and a Plan to Stop It (Twelve, 2011 ).

17 Op. cit., 15.

18 Kurt Weyland, (1998) Politics of Corruption in Latin America, 9 (2) Journal of Democracy (1998).

19 Irma E. Sandoval-Ballesteros, From 'Institutional' to 'Structural' Corruption: Rethinking Accountability in a World of Public-Private Partnerships 9, Edmond J. Safra Working Papers, No. 33, Harvard University (2013). 
concept not just beyond the individual but beyond an institution, SandovalBallesteros sees this form of social domination as emerging not just from bureaucracy and politics, but also from semi-public organizations, the market, and the private sector all working together. Structural corruption, she contends, is a "highly sophisticated organized system that organically integrates economic, legal, social, administrative and political subsystems, linking lower and mid-level extortions, payoffs, bribes, etc. within a complete pyramidal structure of clientelism, institutionalized patronage, and impunity". 20 "What is ultimately in play within structural corruption is an environment of authoritarianism and social exclusion". ${ }^{21}$ Or as Przeworski notes, "The corruption of politics by money is a structural feature of democracy in economically unequal societies". 22

By drawing our attention to these systemic elements and the nature of decision making, these thicker definitions of corruption retrain our focus in two ways. First, they draw attention away from exclusively illegal behavior by individuals - a product of using the law as the standard determining corruption - to incorporate what some refer to as "legal" and institutional forms of corruption. ${ }^{23}$ Indeed, Thompson, Lessig and Johnston all focus on the legal forms of corruption occurring in the U.S., including campaign contributions and the buying of access and influence in Congress. ${ }^{24}$ Second, this new thicker, institutional/structural approach to corruption illuminates the political, decision-making arena rather than the administrative and implementation realm of politics most commonly associated with corruption. In contrasting these two arenas, Warren draws an important distinction between first and second order norms. First order norms, he notes, refer to the rules already crafted and set in law and policy. These prevail primarily within the administrative and executive realms. Second order norms, by contrast, guide and orient the process of deciding first order norms, and refer to more amorphous principles of openness, publicity, fairness, and inclusion that seek to control authoritative decision-making. ${ }^{25}$ These relate more to the deliberative

20 Ibid, 11.

21 Ibid, 12.

22 Przeworski 97, supra note 1. Aristotle, in The Social Contract, not only saw the unequal influence of groups over government as a form of corruption, but since this is rooted in societal inequalities, he considered this form of corruption investible (cited in Stephen Holmes, Linajes del Estado de Derecho, in Más Aldá del Acceso a la Información 70 [John M. Ackerman, ed., 2006]).

23 Charles Funderburk, Corruption in the United States: The Access Market, in Political CoRruption in Comparative Perspective: Sources, Status and Prospects. 19 (Funderburk ed., 2012). Thompson, supra note 6.

24 Thompson supra note 6; Lawrence Lessig, Institutional Corruption, Edmond J. Safra Working Papers, No. 1, Harvard University, Edmond J. Safra Center for Ethics (March 15, 2013); and Michael J. Johnston, Syndromes of Corruption: Wealth, Power, and Democracy (Cambridge University Press, 2005).

25 Warren, supra note 12. 
and discretionary side of politics. In many ways, this distinction builds on earlier distinctions in the literature between political versus administrative corruption. ${ }^{26}$

To be sure, those proposing these thicker, systemic views of corruption differentiate it conceptually from the more orthodox view of corruption rooted largely in individual behavior. Wallis, for instance, distinguishes systemic corruption from what he refers to as "venal corruption" defined as the pursuit of private economic interests through the political process. ${ }^{27}$ Warren similarly distinguishes the "corruption of public office" from "corruption of the democratic process". ${ }^{28}$ Thompson, in turn, differentiates between individual and institutional corruption based largely on the nature of the benefit and the service provided in return. ${ }^{29}$ While both forms of corruption effectively bypass the democratic process, institutional corruption involves political as opposed to personal gain, the service the official provides as systematic rather than episodic, and the connection between the benefit and the service as manifesting a tendency that disregards the democratic process. Such differentiation, of course, raises methodological challenges and theoretical questions regarding the relationship between these two classes of corruption: a point touched on later.

\section{Rule of Law}

Like writings on corruption, the literature on the rule of law also presents substantial debate over definition, providing readers with a host of competing meanings. ${ }^{30}$ What is formally referred to as the "thin" definition of the rule of law specifies minimal traits that the law must possess, but says nothing about the law's content. ${ }^{31}$ The "thin" definition, according to Flores and Himma, specifies that the law must be created by authorized bodies, be generalizable, and apply equally to all. 32 "Thicker" or substantive definitions of

26 Bardhan, The Economist's Approach to the Problem of Corruption 34 (2) WorLd Development (2006); James G. Scott, (1972) Comparative Political Corruption (Englewood Cliffs, Prentice-Hall, 1972).

27 Wallis, supra note 10.

28 Warren 46, supra note 13.

29 Thompson, supra note 6.

30 Brian Burge-Hendrix, Plato and the Rule of Law, in Law, Liberty and the Rule of Law (Flores and Himma, ed., 2013); Michael Zurn, Andre Nollkaemper, and Randall Peerenbook, eds. Rule of Law Dynamics in an Era of International and Transnational Governance (Cambridge University Press, 2012).

31 M. H. Kramer, Where Law and Morality Meet (Oxford University Press, 2004); J. Raz, The Authority of Law (Oxford, Clarendon, 1979).

32 Imer B. Flores and Kenneth Einar Himma, eds. Law, Liberty and the Rule of Law (Springer, 2013). For basic principles of the thin definition see Tom Bingham, The Rule of 
the rule of law lay on top of these requirements certain moral or political restrictions relating to the content of the law. These additional restrictions cover a wide range of areas from providing for and protecting basic liberties, private property, and human rights to the separation of powers and mechanisms of accountability and responsiveness. In a typical multi-layered definition encompassing both minimalist and substantive components, the UN Secretary-General's report on The Rule of Law and Transitional Fustice in Conflict and Post-Conflict Societies defines the rule of law as the "principle of governance in which all persons, institutions, and entities, public and private, including the State itself, are accountable to laws that are publicly promulgated, equally enforced, and independently adjudicated and which are consistent with international human rights norms and standards". 33

Clearly, both thin and thick definitions of the rule of law limit state power, but to different degrees. Minimalist or thin definitions restrict internally the conduct of officials by stating clearly that they too must abide by the law and not use power arbitrarily, and externally, claiming they must apply the law equally to all regardless of wealth or connections. Clearly, these components encompass the idea of corruption both in terms of state officials complying with the law, and in terms of favoring the interests of some over others. According to F.A. Hayek:

Stripped of all technicalities, [the 'Rule of Law'] means that government in all its actions is bound by rules fixed and announced beforehand - rules which make it possible to foresee with fair certainty how the authority will use its coercive powers in given circumstances and to plan one's individual affairs on the basis of this knowledge. ${ }^{34}$

Law (London: Allen Lane, 2010), L. L. Fuller, The Morality of Law 2nd edition (Yale University Press, 1969), and Raz, supra note 31. Bingham's widely accepted thin definition lays out eight defining principles: 1) the law must be accessible and so far as possible intelligible, clear and predictable; 2) questions of legal right and liability should ordinarily be resolved by application of the law and not the exercise of discretion; 3) laws should apply equally to all, save to the extent that objective differences justify differentiation; 4) ministers and public officers at all levels must exercise the powers conferred on them in good faith, fairly, for the purposes for which the powers were conferred, without exceeding the limits of such powers and reasonably; 5) the law must afford adequate protection of fundamental human rights; 6) means must be provided for resolving, without prohibitive cost or inordinate delay, bona fide civil disputes which the parties themselves are unable to resolve; 7) adjudicative procedures provided by the state must be fair; and 8) rule of law requires compliance by the state with its obligations in international as in national law.

33 Cited in Agnes Hurwitz and Kaysie Studdard, Rule of Law Programs in Peace Operations 2, Policy Paper of the International Peace Academy (August 2005).

34 F.A. Hayek, The Road to Serfdom 72 (University of Chicago Press, 1944) cited in Courtney Taylor Hamara, The Concept of the Rule of Law, in Law, LiberTy AND THE RULE OF LAW 18 (Imer B. Flores and Kenneth Einar Himma, eds, Springer, 2013). 
In short, the rule of law means that whatever the government does, it does based on law. ${ }^{35}$ Substantive or thicker definitions of the rule of law, in turn, limit state power even further by defining certain "moral" or political standards or restrictions that must be obeyed or respected by the state in the making and the implementation of the law. And just like thicker definitions of corruption that embrace legal forms of corruption, these broader formulas of the rule of law reach beyond the law itself to encompass basic principles of democracy and human rights. Guillermo O'Donnell, who distinguishes a minimal definition of the rule of law from what he appropriately calls the "democratic rule of law", for instance, stresses that the democratic rule of law "ensures political rights, civil liberties and mechanisms of accountability which in turn affirm the political equality of all citizens and constrain potential abuses of state power". ${ }^{36}$ Competing substantive definitions for the rule of law add a range of democratic features or limitations on state power. But despite such differences, according to Raz and O'Donnell, such moral restrictions center on the promotion of the common good and privileging the common over the personal good. ${ }^{37}$

$[\mathrm{T}]$ he rights of judges, of members of the legislature, and of all other legal officeholders are justified by the interests of the office... The ultimate justification of the rights depends on the fact that... they protect and promote the interest of the community as a whole; they promote and protect common goods. ${ }^{38}$

The overlap between corruption and rule of law at this point seems clear. Even a thin, legalistic definition of corruption captures behavior that represents a violation of the rule of law. But the overlap grows when employing thicker definitions of the two concepts. Regardless of the precise substantive components within a thick definition of the rule of law, by incorporating key principles of democracy and notions of the common good into the definition, it seem to parallel Warren's definition of corruption. ${ }^{39}$ Nonetheless, with "legal" corruption encompassed within a thick definition of corruption, these broader definitions of the rule of law suggest that officials may abide a particular law (i.e. act legally), yet fail to abide by the rule of law by way of violating underlying moral or democratic principles. Therefore, rule of law can be seen as extending beyond mere application of the law and formal rules for state

35 Brian Z. Tamanaha, On the Rule of Law: History, Politics, Theory 92 (Cambridge University Press, 2004).

36 Guillermo A. O'Donnell, Why the Rule of Law Matters, 15 (4) Journal of Democracy 32,33 (2004).

37 Raz 38, supra note 31.

38 Guillermo A. O’Donnell, Democracy, Agency and the State: Theory with ComParative Intent 99 (Oxford University Press, 2010).

39 Warren, supra notes 13 and 14. 
actors, to questions of how the law and decisions are made, how discretion is used, and how the law is interpreted and adjudicated. Certainly not all violations of the rule of law constitute corruption, but corruption seems clearly to represent a violation of the rule of law.

\section{Democracy}

Definitions of democracy fit this pattern as well. Years ago, Joseph Schumpeter set the standard for the thin definition by defining democracy in simple institutional and procedural terms as competitive elections. ${ }^{40}$ Many have embraced this minimal approach over the years. But noting how authoritarian regimes normally stage elections, critics contend that merely staging elections is not enough and that more is needed to make a regime truly democratic. The "more" that is required, however, varies but usually includes additional institutional guarantees, some role for the people, and, as definitions thicken, substantive outcomes. Those specifying additional institutional guarantees beyond elections, for instance, add such factors as civil liberties, ${ }^{41}$ freedom of expression and freedom of the press (alternative sources of information), ${ }^{42}$ contestation between legislature and the executive, ${ }^{43}$ horizontal mechanisms of accountability, ${ }^{44}$ the rule of law, ${ }^{45}$ alternation in power, ${ }^{46}$ and even anticorruption laws. ${ }^{47}$ Adding yet another layer (and hence further thickening the definition of democracy), some specify a role for the people, at least within elections, if not beyond. Beetham, for example, contends that the key to de-

40 Joseph Schumpeter, Gapitalism, Socialism, and Democracy 251 (Harper Perennial, 1976).

41 Larry Diamond, Juan J. Linz and Seymour Martin Lipset, Politics in Developing Countries: Comparing Experiences with Democracy (Lynne Rienner, 1990); Freedom House. FreEDOM IN THE WORLD 2010. Reports available at http://wrewe.freedomhouse.org/reports\#. UyR16c7Hiro.

42 Robert A. Dahl, Polyarchy: Participation and Opposition (Yale University Press, 1971).

43 Mike Alvarez, Jose Antonio Cheibub, Fernando Limongi and Adam Przeworski, Classifying Political Regimes, 31 (2) Studies in Comparative International Development (1996).

44 Michael Coppedge, John Gerring, David Altman, Michael Bernhard, Steven Fish, Allen Hicken, Matthew Kroenig, Staffan I. Lindberg, Kelly McMann, Pamela Paxton, Holli A. Semetko, Svend-Erik Skaaning, Jeffrey Staton, and Jan Teorell, Conceptualizing and Measuring Democracy: A New Approach 9 (2) Perspectives on Politics (2011); Francis Fukuyama, Poverty, Inequality, and Democracy: Dealing with Inequality, 22 (3) Journal of Democracy (2011).

45 Fukuyama, supra note 44.

46 Alvarez et al., supra note 43.

47 Freedom House, supra note 41; Christian Welzel and Ronald Inglehart, Empancipative Values and Democracy: Response to Hadenius and Teorell, 41 (3) Studies in Comparative International Development (2006). See also Carles Boix, Michael Miller, and Sebastian Rosato, A Complete Data Set of Political Regimes, 1800-2007, 46 (12) Comparative Political Studies (2012). 
mocracy is not the matrix of rights, liberties and institutions, but "why particular institutions and rights are considered democratic". ${ }^{48}$ In addition, he proceeds to argue that the core idea of democracy is popular rule or control over decision making and political equality; hence institutions are democratic only if they contribute to popular control and political equality. ${ }^{49}$ Indeed, many analysts incorporate a high level of effective suffrage as part of the democratic criteria. ${ }^{50}$ Some go even further than participation to tack on specific substantive outcomes. These broader definitions of democracy reach beyond the political rights associated with elections to encompass social and economic rights and even different versions of equality. ${ }^{51}$ In characterizing the assorted substantive definitions of democracy, Alvarez et al. conclude that the scope of the different features associated with democracy is indeed broad: almost "all normative desirable aspects of political and sometimes even social and economic life are credited as definitional features of democracy". ${ }^{52}$

To begin with, even the thinnest of the thin definitions of democracy - procedural view stressing elections - points to a critical limit on state power: the means of selecting political leaders. Yet even minimalist definitions are not nearly as thin as they may appear. Despite definitions that seem to strive to concentrate solely on the procedural dimension of elections, most add a series of factors deemed necessary in order for elections to be considered truly democratic. ${ }^{53}$ As a general rule, elections must be "free and fair". This, however, is a rather difficult standard to apply and far more complicated than it may first appear. This requirement alone points to certain minimal standards and outcomes regarding the organization of elections, the fairness of the campaigns, the nature of the opposition, the role of the state (and incumbents) in the process, the counting and the reporting of the results, etc. ${ }^{54}$

Of course, such components of democracy, in turn, represent further limits on the use of state power (and the site of substantial abuse or corruption).

48 David Beetham, Democracy and Human Rights 90 (Polity Press, 1999) cited in Carl Henrik Knutsen, Measuring Effective Democracy, 31 (2) International Political Science Review $110(2010)$.

49 Ibid.

50 For example, Kenneth A. Bollen, Issues in the Comparative Measurement of Political Democracy, 44 American Sociological Review (1980); Michael Coppedge and Wolfgang H. Reinicke, Measuring Polyarchy, 25 Studies in Comparative International Development (1990); Dahl, supra note 42; Gerardo L. Munck, and Jay Verkuilen, Conceptualizing and Measuring Democracy, 35 Comparative Political Studies (2002).

51 Coppedge et al., supra note 44; Anthony Giddens, The Third Way: The Renewal of Social Democracy (Polity Press, 1998).

52 Alvarez et al. 4, supra note 43.

53 Stephen Holmes, Constitutionalism, in The Encyclopedia of Democracy Vol. 1 (Seymour M. Lipset, ed., Congressional Quarterly Press, 1995); Alexander, supra note 4.

54 Guillermo A. O’Donnell, Democracy, Law, and Comparative Politics, 36 (1) Studies in Comparative International Development 13 (2001). 
Boix et al., like Coppedge and Reinicke, who incorporate this factor into their definition of democracy, for example, define elections as fair: "if electoral fraud is absent and incumbents do not abuse government power to effectively eliminate the chance of opposition victory through peaceful contestation" (emphasis added). ${ }^{55}$ Clearly, these practices defining democracy envelope certain forms of corruption.

In addition to free and fair, most analysts also specify that elections must also be "competitive", meaning that there must not only be a choice for voters, but there must also be a degree of uncertainty in the outcome: the real possibility that the incumbent will lose and cede power. ${ }^{56}$ Beyond these electoral requirements for democracy to exist, some minimalist definitions add other freedoms and rights considered critical to making elections "free, fair, and competitive". In his definition of democracy, for example, O’Donnell includes not just fair elections, but also a) positive, participatory rights of voting, and b) "a set of freedoms that surround and are necessary supports for the likelihood of such elections and their related participatory rights". ${ }^{57} \mathrm{He}$ maintains that this is still a minimalist definition because it does not encompass all individual rights. ${ }^{58}$

To summarize the conceptual discussion thus far, it appears that while corruption, the rule of law, and democracy focus on restricting the power of the state and the conduct of state officials, there is substantial debate and disagreement over how to define those limits. For thinner approaches, the laws and the formal rules of the system seem to mark these boundaries. The state and its officials must abide by the law, conform to the formal duties of their office, respect the constitutional rights of citizens and behave in accordance to the law, conduct elections to select political leaders, as well as concede power to the victors. From this minimalist perspective, questions regarding corruption, the rule of law, and democracy seem to take on almost a legalistic tone: whether the state and state officials abide by the law, faithfully implement it, and abide the legal limits on how far the state can go in making laws.

55 Boix et al. 1531, supra note 47 like Coppedge and Reinicke, supra note 50.

56 Adam Przeworski, Democracy and the Market (Cambridge University Press, 1991). In his 2010 essay on the limits of self-government, Przeworski 46 (supra note 2) shows how incumbents rarely lose. This is due, in large part, to how the government institutionally never truly provides a level playing field to opponents.

57 O'Donnell 23, supra note 38.

58 Holmes (supra note 53), however, contends that by specifying certain rights and freedoms even so-called minimalist definitions are substantive. The requirement that these rights must exist not only defines elections, he notes, but also places limits on what a democratically elected government can do. Despite Przeworski's (supra note 50) minimalist notion that democracy is merely procedural and "institutionalizes uncertainty" over policy outcomes, democratic governments are not entirely free to operate in any manner they wish. These restrictions thus reduce the range of issues and range of possible outcomes. 
Yet thicker definitions of corruption, rule of law, and democracy reach beyond the law into far murkier terrain with significant overlap among the three. Here, attention comes to center more on whether the state or state officials comply with fundamental principles of democracy, the common good or pursuit of justice. Rather than simply a legalistic reading or emphasizing the proper implementation of the law, these thicker approaches focus more on the political side of the equation, on second order norms, on the spirit rather than the letter of the law, and on the content and substance of democracy rather than its procedural dimension.

\section{ReLATIONSHIPS AMONG \\ Overlapping Concepts}

All this points to significant conceptual overlap, boundaries, and even potential tautologies and oxymora. Table 1 seeks to highlight some of this by exploring the interrelationship of thin and thick definitions of corruption to thin and thick definitions of the rule of law and democracy. The matrix helps raise and address certain questions, some of which were raised at the beginning of this note: Does political corruption undermine the rule of law? Given the conceptual overlap, this question just strikes me as somewhat tautological since political corruption is an example of the failure of state officials (and citizens) to comply with the rule of law. Similarly, does corruption weaken democracy? Again, depending on what definitions we employ, then the absence of corruption (or at least certain forms of corruption) in part defines democracy (and vice versa), rendering the question somewhat tautological. 


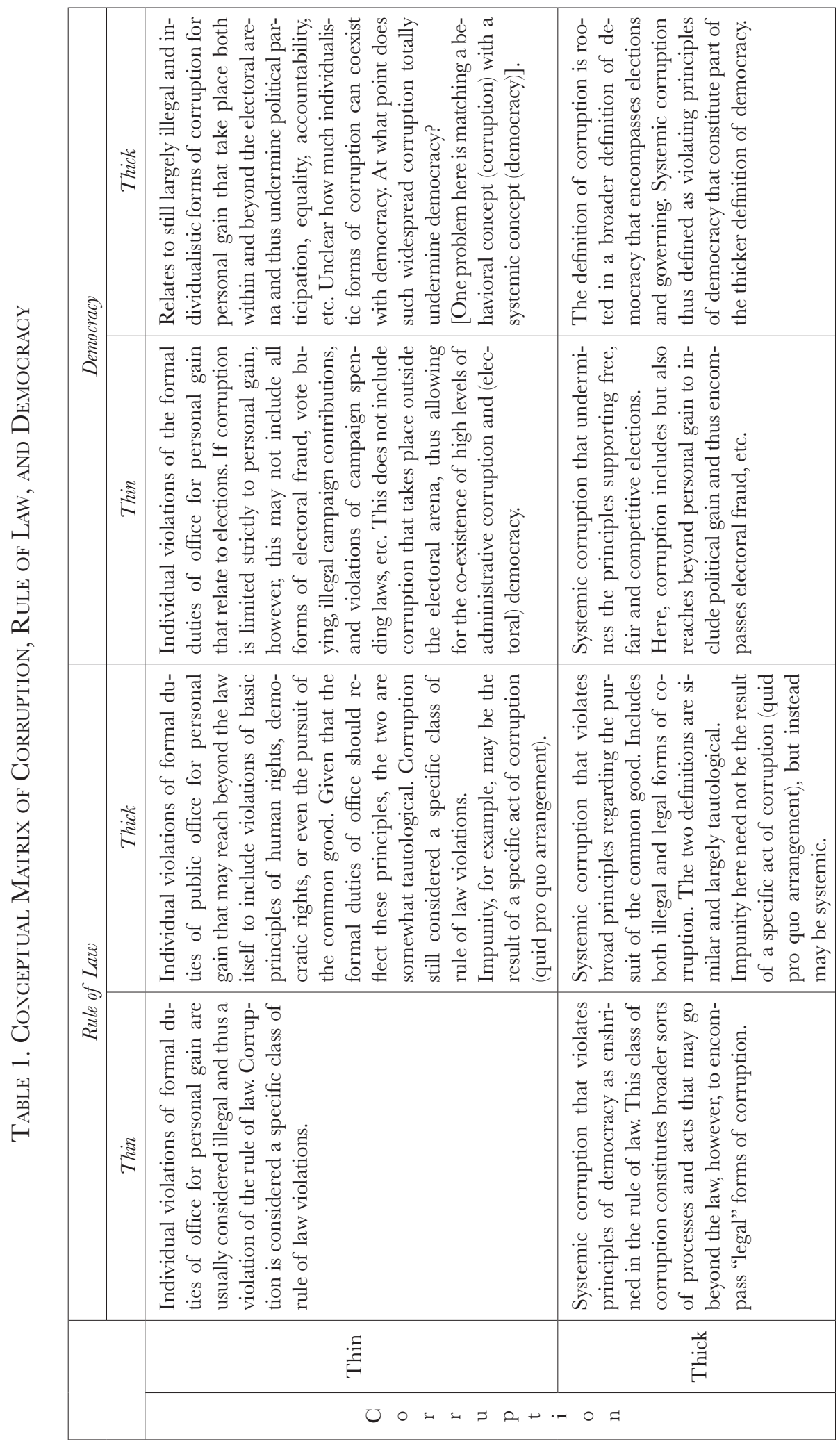


It terms of considering the relationships linking these concepts (and whether such theoretical questions even make sense), it becomes not only a question of conceptual clarity or recognizing the higher and lower order levels of the definitions (that corruption fits within rule of law which in turn fits within democracy). Instead, it centers on disaggregating the concepts and deciding how much of one is needed to determine the other. For instance, corruption represents a wide range of behavior and systemic arrangements. In a direct sense, corruption among police and the criminal courts undermines the state's enforcement of criminal law, while corruption within the courts and administrative levels undermines the implementation of civil and administrative law. If we employ thicker definitions of corruption and/or the rule of law, the degree of conceptual overlap expands. As noted, corruption in many of its forms (bribery, procurement corruption, conflict of interest, favoritism, graft, etc.) represents a failure of the government to either abide by the law and rules, or at least be held accountable. In this sense, corruption is certainly part of the violation of the rule of law - hence the conceptual overlap - but it is not the same thing. Nonetheless, corruption is not the only cause of the weak rule of law since deficiencies may reflect a wide range of factors from governmental structure (lack of judicial independence), political interference in the courts, and access to the legal system to the lack of resources and training among police and prosecutors. Corruption thus represents a lower level concept compared to rule of law.

Does political corruption undermine democracy? Most theories and studies, including my own, support this view. Noting the substantive relationship between democracy and the rule of law, the Inter-American Commission for Human Rights, for example, contends "that corruption constitutes a phenomenon that affects democratic institutions". ${ }^{59}$ But given the conceptual overlaps, such a question may be considered leaning at least toward tautology. Rather than affecting democracy, corruption represents, at least in part, the absence of democracy. Even using thin definitions of both corruption and democracy, certain types of corruption directly impact democracy and by definition undermine it. This includes, first and foremost, corruption related to electoral processes (electoral fraud, violation of campaign spending limits, etc.), and, secondly, the supporting political rights normally associated with free, fair and competitive elections. In other words, these forms of corruption undermine the fundamental qualities of democracy, disqualifying the regime as democratic: the two phenomena are not distinct. Within this narrow, thin perspective, of course, most traditional forms of bureaucratic corruption - bribery, extortion, conflicts of interest, etc. - arguably have little to no impact on elections and hence a thin minimalist definition of democracy. Here, the theoretical question makes sense: it is possible for democracy (defined as free and fair

59 Comisión Interamericana de Derechos Humanos, Corrupción y Derechos Humanos: Estándares Interamericanos 56 (Organización de Estados Americanos, 2019). 
elections) to co-exist with corruption (if by corruption you exclude corruption that undermines elections).

Moving beyond thin definitions the tautology and the connection between corruption and democracy become even greater. A broader definition of corruption means that corruption represents violations of the basic principles of democracy; similarly, a thick definition of democracy that includes accountability makes corruption a violation of the principles of democracy. As with the rule of law, corruption is not the only cause for the absence of democracy, but if the definition of democracy encompasses accountability, its presence would seem to disqualify a country as being democratic. This renders largely tautological the theoretical question of the relationship linking corruption to democracy.

Questions not shown in Table 1 can also be raised. Does weak rule of law undermine democracy? As with corruption, it largely depends on the specific types of rule of law problems. Weak rule of law related to campaigns and elections, which may undermine free, fair, and competitive elections, clearly distorts even a thin version of democracy. For thin definitions of democracy, however, weak rule of law in terms of criminal or civil enforcement, protection of private property, equal access to justice, equal treatment under the law, judicial independence, or obedience to the law really have no direct effect on democracy. As definitions thicken, of course, these concerns point to the weakness or lack of democracy and become increasingly tautological.

\section{Gonclusion: So?}

Beyond the importance of conceptual clarity ${ }^{60}$ the current analysis raises questions regarding measures used to conduct empirical research and the results obtained. It also highlights how the multidimensional nature of the three concepts facilitate questions about the theoretical relationships among the various internal components of each. First, the overlap among the definitions of corruption, rule of law and democracy presents empirical challenges and the potential for endogeneity if used in an empirical model. Rather rudimentary measures of corruption are based on simple perceptions of corruption, while seemingly more sophisticated indices gauging the rule of law and democracy tend to incorporate among the range of indicators measures of corruption, its antithesis like accountability or, in the case of democracy, indicators of the rule of law, again highlighting the potential problem of endogeneity. Though a thorough review has been omitted for space purposes, a few examples serve to highlight the problem.

To begin with, many of the empirical measures of corruption center on perceptions, yet what those perceptions encompass remains unclear. Not only

60 Giovanni Sartori, Concept Misinformation in Comparative Politics, 64 American Political SciENCE REVIEW (1970). 
do we not know whether the subjective opinions reflect thin or thicker definitions of corruption, but it is also probable that perceptions of the rule of law and democracy are conflated within those perceptions of corruption. ${ }^{61}$ At the same time, the vast measures of the rule of law normally gauge whether state officials abide by the law and the norms governing their formal responsibilities: a clear reference to the essence of corruption. ${ }^{62}$ What has been said raises the question of whether a country could enjoy a high level of rule of law and yet widespread corruption, or the utility of a cross-national analysis regressing corruption along a measure of the rule of law. Indeed, one of the four components used to construct the World Justice Index (WJI) of the rule of law, for example, is whether government and its officials and agents are accountable under the law. Finally, measures of democracy frequently incorporate elements of both the rule of law and corruption. ${ }^{63}$ For instance, one of the 10 questions Freedom Houses uses in calculating its political rights index is whether the government is free from pervasive corruption, while another question asks about government accountability to the electorate between elections and whether it operates with openness and transparency. In fact, its political rights index even incorporates Transparency International's Corruption Perception Index. In a similar manner, the Polity IV scale of democracy includes among its components the existence of institutionalized constraints on the exercise of power by the executive: or, in short, a key component of anticorruption. ${ }^{64}$ Boix's et al. "complete data set of political regimes" stretching from 1800 to 2007 includes a measure of democracy that incorporates electoral fraud (a form of corruption), ${ }^{65}$ while Inglehart and Welzel's effective democracy index uses

61 Some contend that they reach beyond corruption to incorporate feelings about the government or even normative prejudices about the form of government. See John Bailey, Corruption and Democratic Governability in Latin America: Toward a Map of Types, Arenas, Perceptions, and Linkages, in Corruption and Democracy in Latin America (Charles H. Blake and Stephen D. Morris, eds., 2009). For discussion of the measures of corruption see Arturo Del Castillo, Medición de la CORRUPCión: un INDiCADOR DE LA RENDición de Cuentas (Mexico City: Auditoría Superior de la Nación 2003); Staffan Andersson, Beyond Unidimensional Measurement of Corruption, 19 (1) PuBLIC Integrity (2017); C. R. Apaza, Measuring Governance and Corruption through the Worldwide Governance Indicators: Critiques, Responses, and Ongoing Scholarly Discussion, 42 (1) PS: Political Science \& PoliTICs (2017); Tina Søreide, Is it Wrong to Rank? A Critical Assessment of Corruption Indices (Working 559 Paper, Chr. Michelsen Institute, 2006).

62 For reviews on existing measures of the rule of law see Wolfgang Merkel, Measuring the Quality of Rule of Law: Virtues, Perils, and Results, in Rule of Law Dynamics in an Era of International and Transnational Governance (Cambridge University Press, 2012) and Svend-Erik Skaaaning, Measuring the Rule of Law 63 (2) Political Research Quarterly (2010).

63 On measures of democracy see for instance Alex Inkles, ed. On Measuring Democracy (New Brunswick: Transaction, 1991); Kenneth A. Bollen, Liberal Democracy: Validity and Method Factors in Cross-National Measures, 37 (4) American Journal of Political Science (1993).

64 Polity IV Project: Political Regime Characteristics and Transitions, 1800-2012. Available at http://wrere.systemicpeace.org/polity/polity4.htm.

65 Boix's et al., supra note 47. 
either Transparency International's Corruption Perception Index (CPI) or the Control of Corruption index (CCI) from the World Governance Indicators (WGI). ${ }^{66}$ Interestingly - and tellingly from the perspective of this essay - the latter employs corruption as a proxy measure for the rule of law. ${ }^{67}$

Second, the current survey reveals the complexity and multidimensionality of corruption, the rule of law, and democracy - the many factors feeding competing definitions. This aggregation not only raises questions as to the validity of empirical measures as just noted, ${ }^{68}$ but also tends to obscure a deeper understanding of the rich internal attributes and questions about the theoretical relationships linking these internal components. What is the relationship, for instance, between corruption of public office (thin definition) and corruption of the democratic process (thick definition)? What is the relationship between legal and illegal forms of corruption, or high- and low-level forms of corruption, between corruption involving first order norms and second order norms? Does low-level, administrative corruption facilitate or inhibit higherlevel institutional or structural corruption? ${ }^{69}$ Is there an underlying tendency within societies away from illegal forms of corruption to more legal variants? Within the rule of law, under what conditions do the various aspects of the rule of law go together or collide? What factors and patterns shape impunity? Is there one legal system for the rich and another for the poor? Are certain rights more rigorously protected or certain laws better enforced than others? As for democracy, can free and fair elections coexist with the absence of accountability? To be sure, many have grappled with such issues. Exploring these issues at an empirical level, however, is complicated by the tendency to aggregate so many of these traits into singular metrics.

In pointing to the two common themes underlying corruption, rule of law, and democracy, the analysis helps us view corruption in a broader framework. The first relates to limits on the exercise of power by the state and state officials. In most cases, these limits are clearly defined by the laws, constitutional provisions and structures, and written rules and policies. Such first order norms define the normal duties of public offices, and the legal processes and procedures to make and implement authoritative decisions, to stage free,

66 Ronald Inglehart and Ghristian Welzel, Modernization, Gultural Ghange, and Democracy: The Human Development Sequence (Cambridge University Press, 2005) and Welzel and Inglehart, supra note 47.

67 Knutsen 116, supra note 48.

68 See Munck and Verkuilen, supra note 50.

69 Do they all represent a common underlying phenomenon? Johnston's (supra note 24) path-setting work provided a broad initial answer to this question, showing how patterns or syndromes of corruption in fact vary across countries: in other words that not all forms of corruption go together. The influence market corruption found in the US, for example, represents more the institutional and structural variants of corruption, while the elite cartel corruption found in Mexico includes more clearly illegal, administrative, and individualistic variants of corruption. Yet few have followed up on this approach. 
fair, competitive elections, etc. These norms are the historic by-product of societal interaction, power balances, negotiations, ideological struggles, compromises, crises and reforms, and conflicts that continue to play out. Consequently, clearly corrupt and blatantly anti-democratic acts are proscribed and illegal, making many, if not most, violations easy to spot, perceive, and count.

But just as the behavior of state officials, and citizens must conform to the law, those making decisions in the name of the state also face limits on how they arrive at their decisions and how they use their power and authority; i.e. second order norms. These limits, however, often go beyond the easily identifiable and quantifiable to encompass far more ambiguous and contested criteria rooted in the principles of democracy: the second common theme here. Corruption, as noted, goes beyond merely violating corruption statutes to include privileging the interest of some over others, the duplicitous exclusion of those affected by decisions from equal access to the decision makers, or when those making, implementing, or adjudicating the law take into account personal, partisan or other interests that do not center exclusively on the wellbeing of the people. Violating the rule of law similarly goes beyond merely breaking the law or even abiding by the "letter of the law" to incorporate criteria relating to the content of the law and the motives and reasons behind its creation, implementation or adjudication (thick or substantive definitions). In a similar manner, democracy is more than elections (thin definition), but fundamentally requires a government that is restricted in its use of power and bound by criteria involving the principles of inclusiveness, the privileging of the common good, accountability, responsiveness, and fundamental notions of justice (thick or substantive definitions).

For this reason, while aggregation pulls together multifaceted phenomenon to create the concepts of corruption, rule of law and democracy, these can be unpacked and explored. It is here where corruption broadly conceived becomes part of a larger concern over the perceived and real limits on (or abuse of) state power. This goes beyond questions about the patterns of corruption in a narrow sense to crystallize questions about the relationship between corruption and other abuses of state power or rule of law violations such as the abuse of human rights, the existence of informal rules in the decision-making process, clientelism, impunity, or the differential application of the law based on socioeconomic standing. Though this discussion has not encompassed society per se, corruption broadly conceived also raises questions cutting across state and society. For example, how does corruption or other broader violations of the rule of law or democracy by state officials influence society's ideas of legitimacy or of their obedience to the rule of law? Simply stated, does a high level of corruption (illegalities by officials) encourage citizens to break or bend the law whenever and wherever possible? In short, does state crime feed social crime? ${ }^{70}$ To broaden the matter a bit more, to what extent might corruption or

70 See, Stephen D. Morris, Mexico's Political Culture: The Unrule of Law and Corruption as a Form of Resistance, III (2) Mexican Law Review (2011). 
Esta revista forma parte del acervo de la Biblioteca Jurídica Virtual del Instituto de Investigaciones Jurídicas de la UNAM

other violations of the rule of law help hold democracy in check (by ensuring elite rule and preventing the people from making "certain" decisions) rather than the other way around? Under certain conditions, in a sort of Aristotelian balance, corruption and democracy may effectively co-exist with corruption taming democracy while democracy constrains corruption. 